


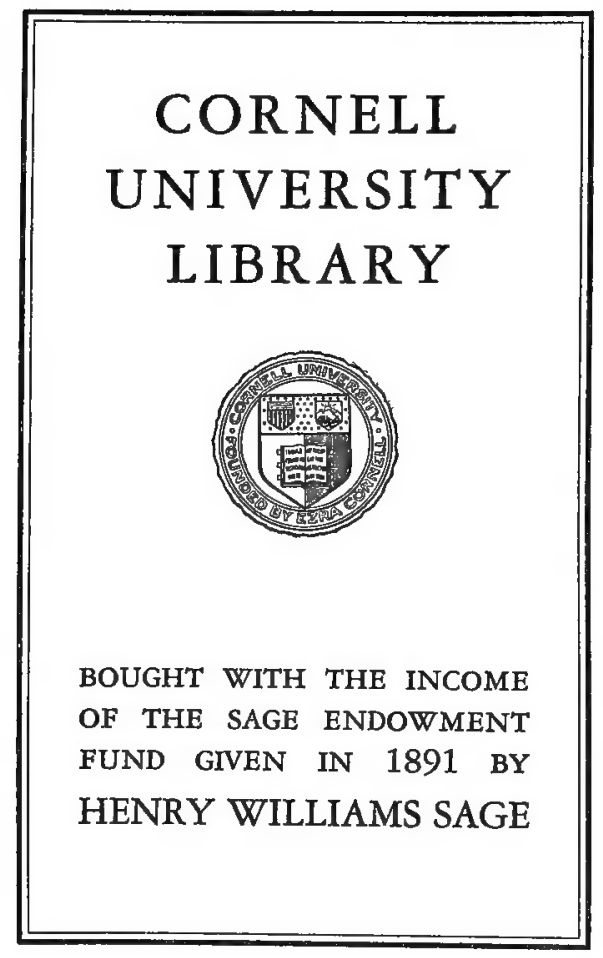

\section{RETURN TO}

\section{ALBERT R. MANN LIBRARY}

ITHACA, N. Y. 
QK 643 Cornell University Library

Morphology of spermatophytes.[Part I. Gy H.

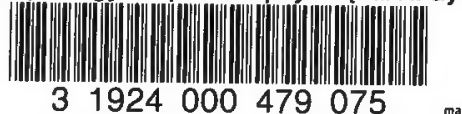




\section{Cornell University Library}

The original of this book is in the Cornell University Library.

There are no known copyright restrictions in the United States on the use of the text. 
MORPHOLOGY OF SPERMATOPHYTES 



\section{MORPHOLOGY \\ OF SPPERMATOPHYTES}

BY

JOHN M. COULTER, PH. D.

HEAD OF THE DEPARTMENT OF BOTANY IN THE UNIVERSITY OF CHICAGO

AND

CHARLES J. CHAMBERLAIN, Ph. D.

INSTRUCTOR IN BOTANY IN THE UNIVERSITY OF CHICAGO

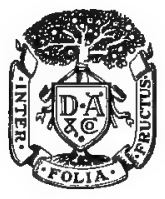

NEW YORK

D. APPLETON AND COMPANY 



\section{P R E F A C E}

THIs book has grown out of a course of lectures, accompanied by laboratory work, given for several successive years. The course presupposes at least a year of work in general morphology, and is intended to prepare the student for research in the morphology of Seed-plants. As a consequence, the book brings together and organizes the very voluminous and scattered literature of the subject, points out and discusses the problems, seeks to unify a very confusing terminology, and at the same time contributes no small amount of original observation and illustration.

In developing the subject it has been thought best to present first the facts connected with the different groups, organizing these facts in as systematic and definite a way as possible, so that the condition of knowledge in reference to any feature may stand out clearly. Following the presentation of the separate great groups, their comparative morphology, history, and phylogeny are discussed.

At the end of each chapter which discusses a great group, a list of the works cited is given. This bibliography is not intended to be exhaustive, but to include those works which contain definite contributions of fact or of opinion. At the close of the volume there will be found a fairly complete bibliography of the important papers.

While in the very nature of things the great body of material in a book of this kind must be derived from the work of numerous observers, yet most of the ground has been traversed 
several times by the authors and their students, certain gaps have been filled up, and an original point of view has been established. So far as possible, the illustrations are original, and some of the series are more complete than any heretofore published; but illustrations have been reproduced whenever they seem necessary to a full understanding of the subject. Those which have been copied are fully credited, and may thus be distinguished from those which are published for the first time in this book. References to figures in the text have not been multiplied, upon the assumption that those who use the book are in the habit of consulting figures.

One of the chief perplexities in connection with the literature of the subject is the confusing and often misleading terminology employed by various authors. Not only have different names been applied to a single morphological structure, but frequently the same name has been used for very different structures. This has resulted not only in a confusion of terms, but in greatly obscuring a very simple and consistent morphology. We have attempted to introduce uniformity into the terminology, not by proposing new names, but by selecting from those already current the ones which seem the most appropriate. It is to be hoped that this will aid to a better understanding of morphological equivalents.

It may be well to call attention to the fact that we close the history of the sporophyte with the appearance of the spore mother cell, rather than with the appearance of the spore. This has seemed to us to be the best defined line of demarcation between the two generations, both on account of the reduction division, and because preceding this dirision the mother cell passes into a more or less prolonged resting condition. It certainly represents the greatest break in the continuity of the life history. In this sense, therefore, the sporophyte ends with the appearance of the spore mother cell, and later the gametophyte begins with the reduction division. 
No attempt has been made to present the anatomy of Seedplants. This subject is too vast, and too far removed from our general purpose to be included. The few anatomical details which have been given are simply those which have to do with the general structure of organs, and which are essential to any morphological discussion.

The authors appreciate the fact that, in a certain sense, a book of this nature is out of date as soon as it has left the press, especially as it deals with groups which are being investigated at the present time with remarkable activity. Doubtless, within a few months papers will appear which would have been of great service; but in so large a group this is likely to remain always true, and the authors have felt that a concise summary of knowledge at any stage of progress is useful in stimulating and guiding further research.

John M. Coulter.

Charles J. Chamberlain.

The University of Chicago, January, 1901. 



\section{O N T E N T S}

PART I.-GYMNOSPERMS

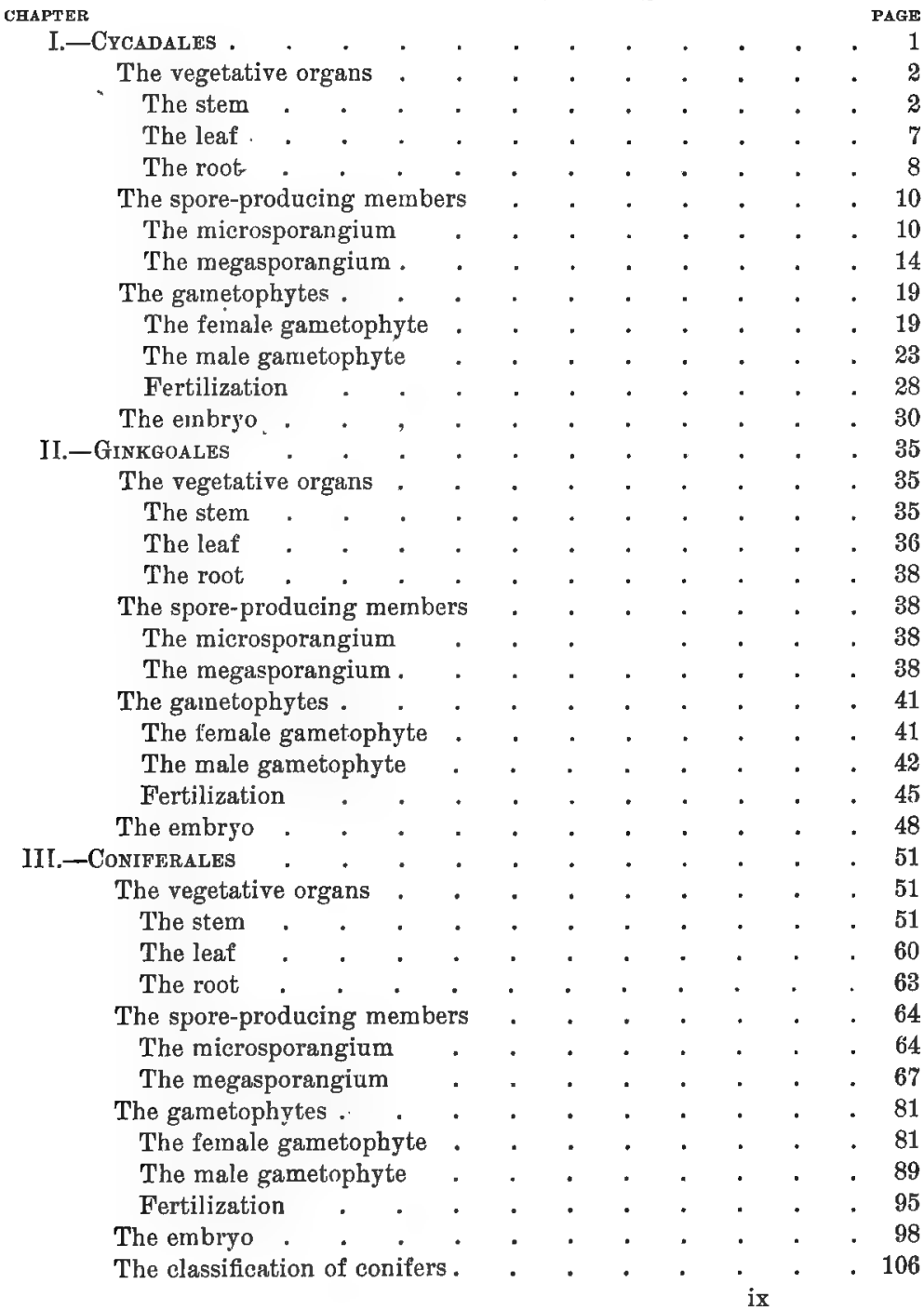




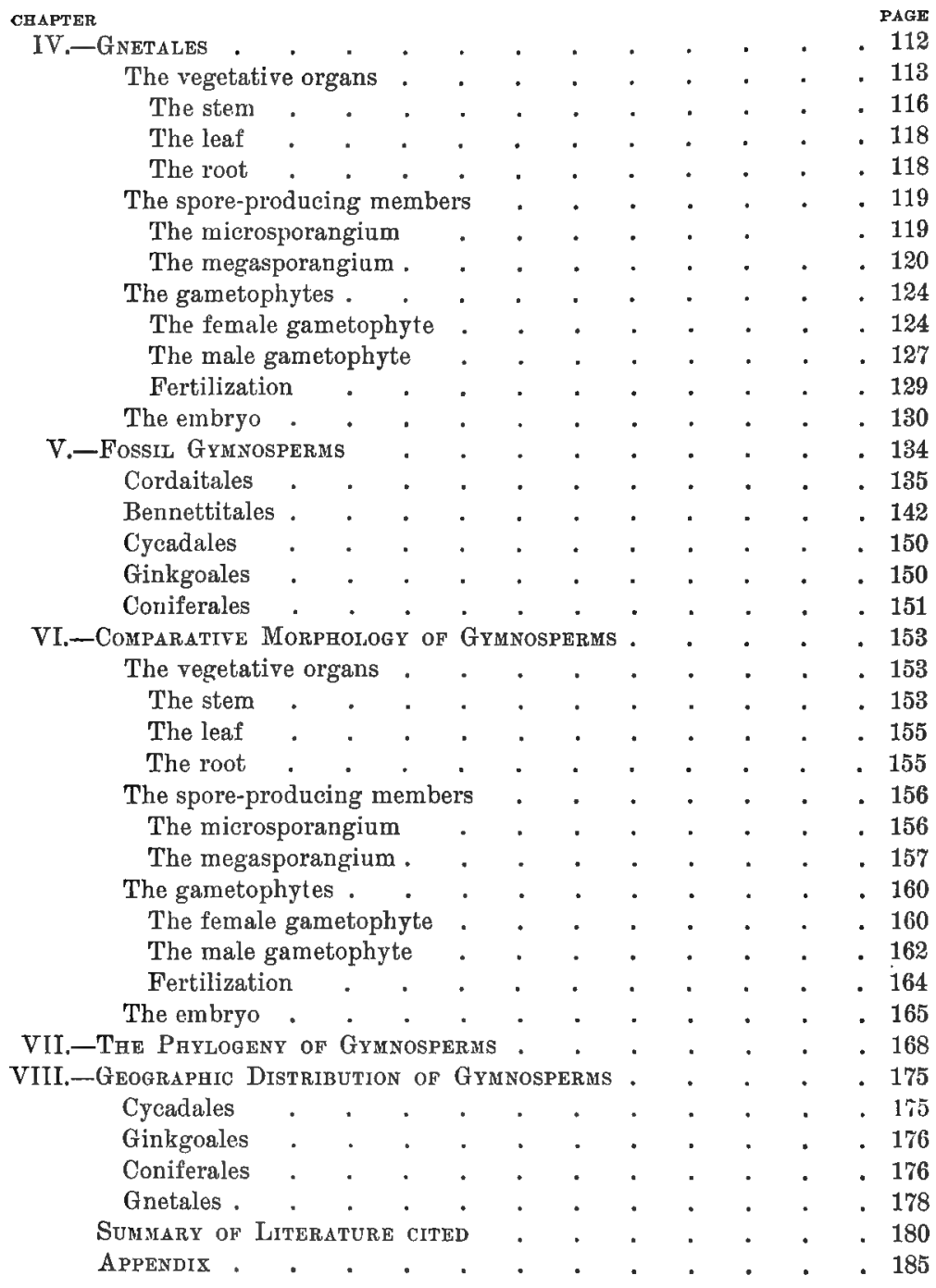




\title{
MORPHOLOGY OF SPERMATOPHYTES
}

\author{
PART I.-GYMNOSPERMS
}

CHAPTER I

\section{Cycadales}

Is the present flora nine genera of Cyeads are recognized, containing between seventy-five and one hundred species, and distributed about equally between the oriental and occidental tropics. The group is of special interest on account of its fernlike characters, but knowledge of the most critical structures is confined to comparatively few genera and species. With the establishment of laboratories in regions where Cycads are indigenous, and with the increased attention paid to their cultivation, there is every reason to hope that the group will soon be fairly well understood, so far as its living representatives are concerned. The following account merely summarizes the meager information at present available, which may or may not find general application in the group.

The gross character which serves to distinguish Cyeads from other Gymnosperm groups is the combination of unbranched stems with a terminal rosette of comparatively few large and branched leaves, which gives to the columnar forms the habit of tree ferns or palms (Figs. 1, 2, 3, 4). The most remarkable recondite character of the group, a character which it shares with Ginkgo, is the occurrence of peculiar multiciliate male cells, demonstrated as yet only for Cycas, Zamia, and Stangeria, but probably common to the whole group. 
I. THE VEGETATIVE ORGANS

TIE STEXI

The columnar or tuberous stems, with no distinguishable internodes, are usually completely invested by an armor of thick

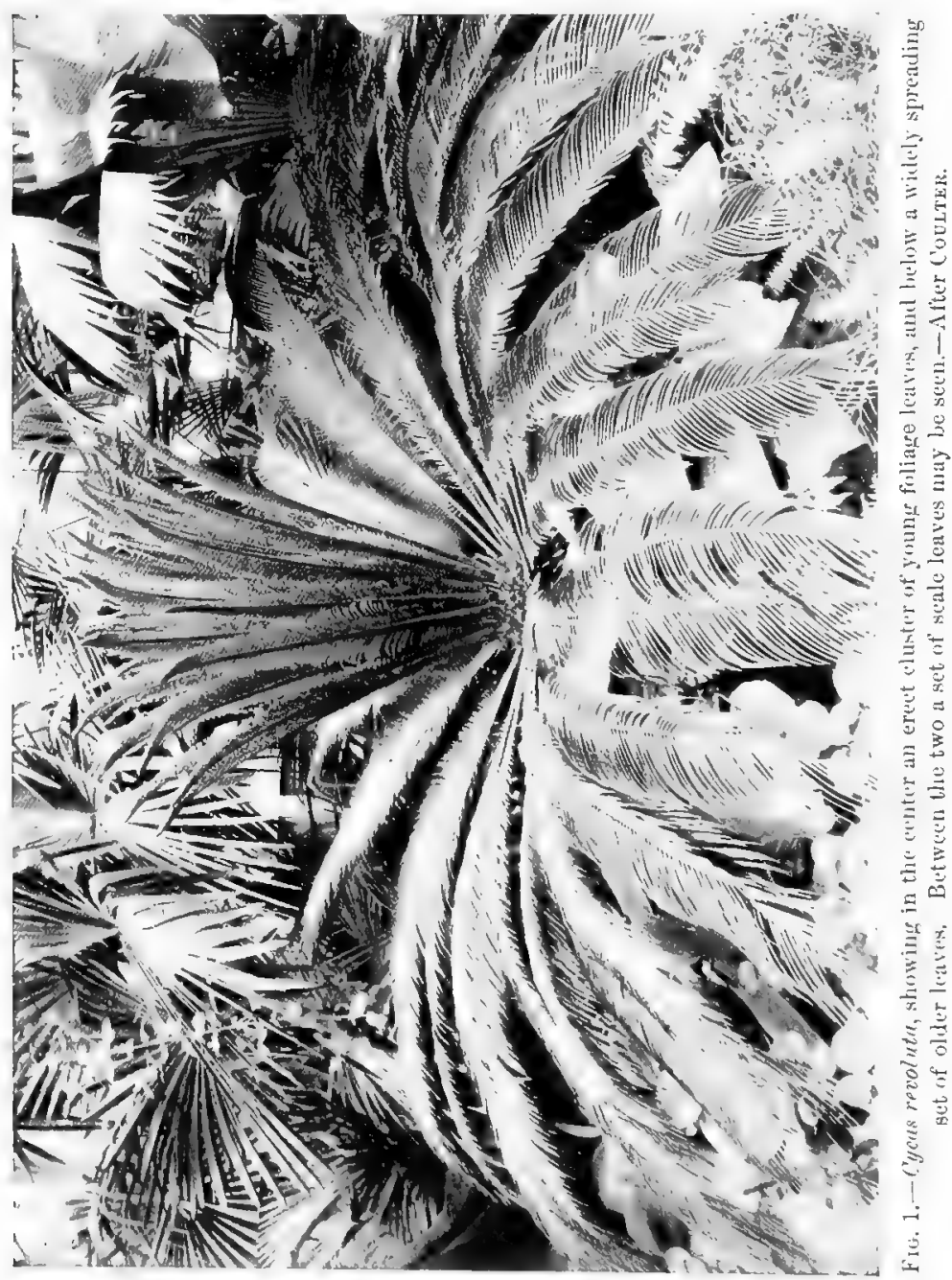

leaf bases and scale leaves, some tuberous stems resembling lunge comes. P'rohahly the greatest height is attained ly species 
of Cycas, some of which carry the crown of leaves upon a columnar trunk 3 to 4 meters, or sometimes even 12 meters high, while the Australian Cycas media reaches a height of over 20 meters; but, in the majority of cases, the stem is short and stocky, assuming the so-called tuberous form. In fact, all the stems when young have the tuberous form, and the difference between the two types consists in the one retaining this form and the othei hecoming columnar. Branched forms are rare in nature, but seem to be more common in cultivation. We are informed that wild plants are apt to branch after they reach a certain age.

Until recently, the accounts of the histology of the stem have been derived in the main from species of Cycas, Encephalartos, and Stangeria. A historical résumé of the subject was published by Worsdell ${ }^{21}$ in connection with his work upon Macrozamia, the substance of which is as follows: In 1829 Brongniart ${ }^{1}$ gave some account of the anatomy of the stem of Cycas revoluta, refuting the idea that Cycadean stems are similar to those of Monocotyledons, and pointing out their true Gymnosperm character. He claimed,

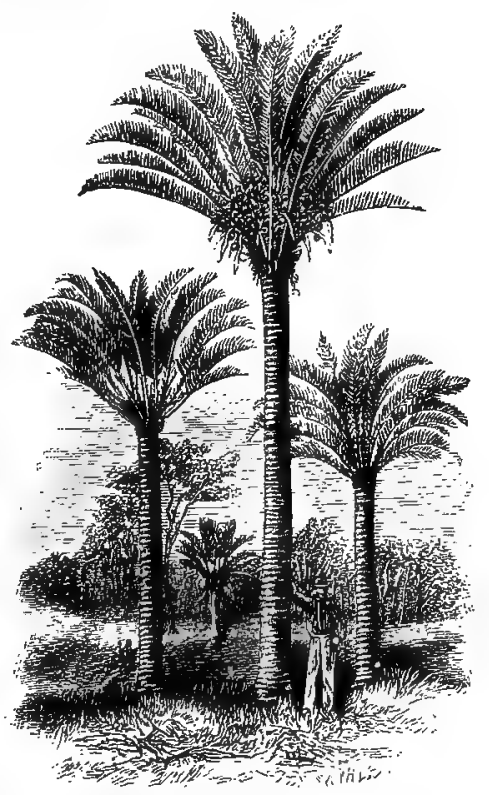

Fia. 2,-Cycas nuedia in the middle and at the right; Cycas Normanbyana at the left.-After H. Vor Muller. however, that there is no phloem, and that xylem is the only vascular tissue developed. In $1832 \mathrm{Von} \mathrm{Mohl}{ }^{2}$ published an account of the stem anatomy of $C y c a s$ and two species of $E n$ cephalartos (referred at that time to Zamia, and known as $Z$. latifolia and $Z$. horrida). In one of the species of Encephalartos (his $Z$. latifolia, but an African Encephalartos not to be confused with $Z$. latifolia Loddiges) he discovered the meshwork of vascular bundles in the pith, and the fact that single bundles traverse the pith rays and enter the cortex. In $1841 \mathrm{Miquel}^{3}$ 
published his great monograph of the group, and incidentally touched upon the stem anatomy of several genera. In 1861 Mettenius ${ }^{4}$ published an account of Cycadean stems which has remained until recently the chief source of information about them. He included Cycas revoluta, Encephalartos horrida, Dioon edule, and Zamia muricata, finding in the last two genera none of the secondary cortical bundles characteristic of the first two. In 1885 Costantin and Morot ${ }^{15}$ published an account of the structure of the pericycle of Cycas Siamensis, claiming that in it the cortical cambium zones have their origin. In 1890 Solms-Laubach ${ }^{17}$ published an account of Stangeria paradoxa,

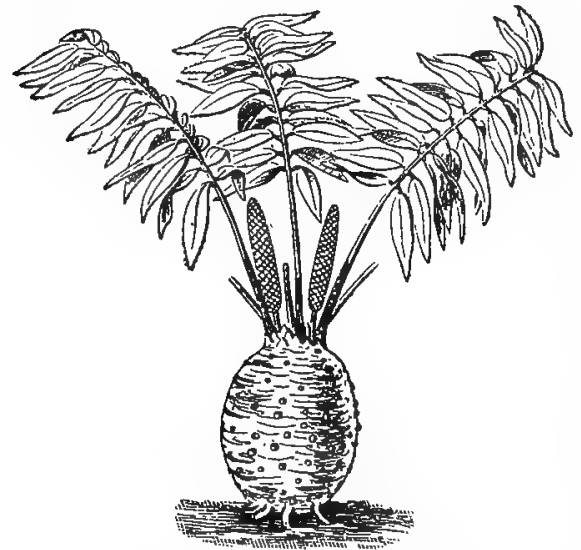

Fra. 3. - Stangeria paradoxa, staminate plant; about one fifteenth natural size.-From Warming-Potter's Handbook of Systematic Botany. in which the vascular bundles are traced from the peduncles to their juncture with the stem system, and no evidence of secondary cortical bundles is found. In 1891 Strasburger ${ }^{18}$ brought together the knowledge of stem anatomy with reference to Cycas, but did not include other genera. The most important contributions to the knowledge of stem anatomy since are those of Worsdell 21, 30 on Macrozamia and Bowenia, and that of Scott ${ }^{24}$ on the peduncles of Cycads.

The structure common to all of the stems investigated is a large pith surrounded by a thick cylinder of open collateral bundles and broad pith rays, and a conspicuous cortical region. The primary bundles are common, and the primary cambium is either short-lived or somewhat persistent. In $Z_{\text {amia, Dioon, }}$ and Stangeria no further structures occur to interfere with the resemblance to an ordinary coniferous or dicotyledonous stem, and secondary thickening, whatever it may amount to, is effected by the primary cambium.

A conspicuous feature of the structure of Cycas, Encephal- 
artos, Macrozamia, and Bowenia, howerer, is the development of a series of scondary cortical cauline l,undles by successive secondary cambium cylinders. In these cases the primary cambinm
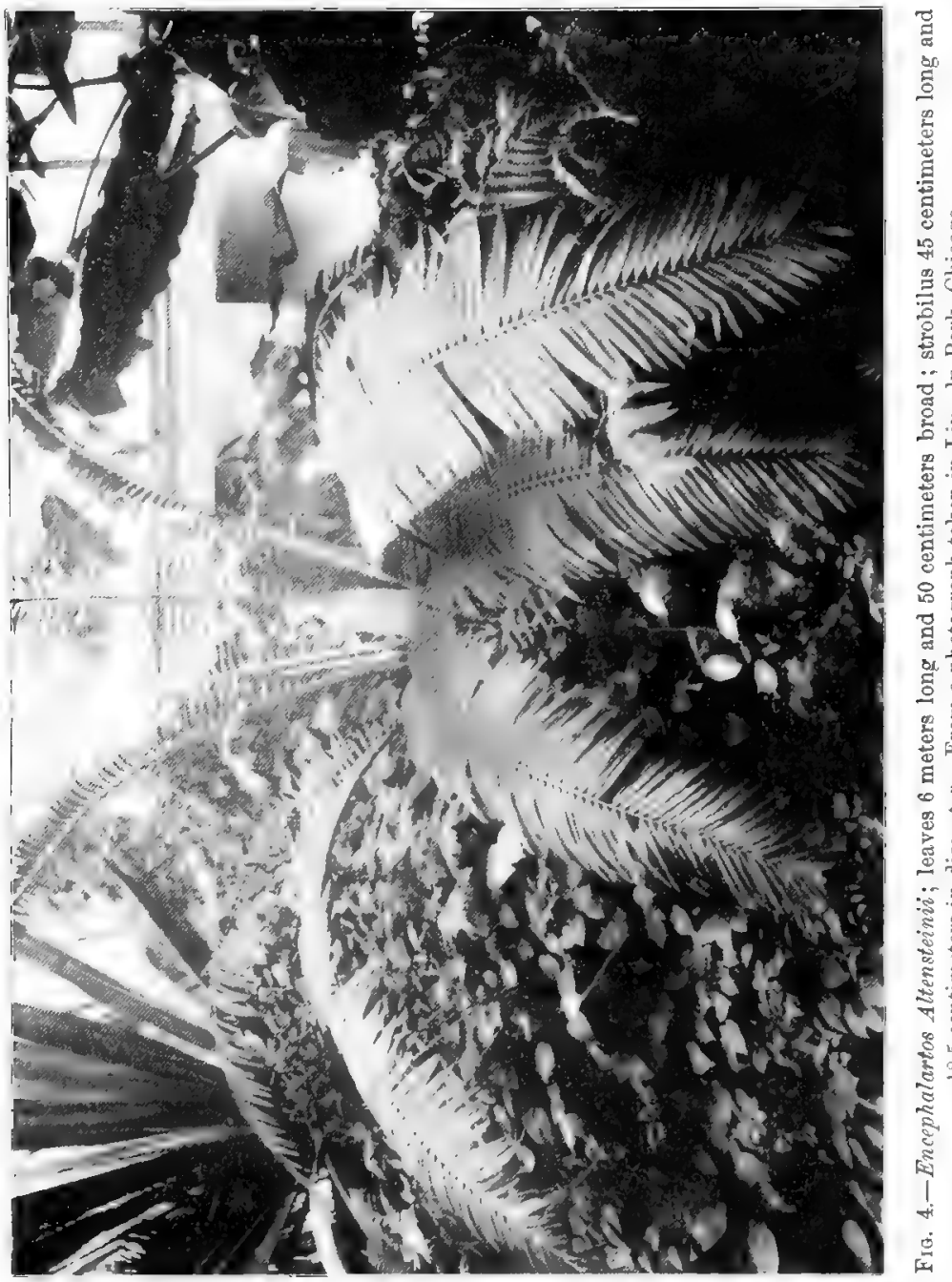

is slort-lived, and a series of seenndary cambiums is organized in the cortex, the first giving rise to a vascular cylinder as prominent as the primary one, the second developing much smaller and 
more widely separated bundles, and so with diminishing constructive power until the outermost cylinder is recognized only by the appearance of a small bundle here and there. In Cycas these cortical bundles are concentric, as are the bundles of the peduncles and leaves of Cycas, Stangeria, Bowenia, and some species of Zamia and Ceratozamia. Moreover, in Macrozamia and Bowenia Worsdell discovered what may be called a tertiary cambium, developed between the successive secondary cambiums, and giving rise to small intermediate bundles with reversed orientation-that is, with xylem directed toward the xylem of the next outer bundles. This suggests that the original structure of all the cortical bundles was concentric, and that in the layers of concentric bundles the meristem of the inner portion of each bundle becane gradually less functional, until in most cases the concentric bundles have become collateral.

Such facts as the cortical concentric bundles of Cycas, the concentric bundles in the peduncles and leaves of several genera, the evidence of incomplete concentric bundles in Macrozamia and Bowenia, all point to an ancient stem type in which layers of concentric bundles were developed. It is important to note, as Scott ${ }^{24}$ has suggested, that such a stem type is indicated in several large extinct groups, as Lyginodendreae, Poroxyleae, Protopitycae, and Medulloseae, representing the so-called Creadofilices, and that the living Cycads constitute only a special group of what was once an extensive alliance. In Cycas, probably the most primitive of the living genera, the concentric character of the cortical bundles is retained; in MTacrozamia and Bowenia remnants of the inner part of the concentric bundles exist; while in still other genera vestiges of the primitive organization once common to the stem also survive only in peduncles. The fact that the concentric bundle is a prominent feature of the Pteridophytes, and that it is the prevailing one in Paleozoic vascular plants, emphasizes the general ancient as well as Pteridophyte character of the Creirds.

In Encephalartos and Macrozamin a system of cauline bundles is also dereloped in the pith, forming a dense network traversing the pith in erery direction, each bundle attended by a mucilage canal in contact with the phlocm. Certain smaller bundles pass out through the pith rays, the xylem and phloem strands joining the corresponding elcments of the primary eyl- 
inder, and the mucilage canals passing on to join the cortical canal system.

The xylem elements are of the general Grmnosperm character. They are all tracheids, the first formed being spiral in type and the later scalariform; while in the tracheids of the secondary xylem the characteristic bordered pits appear, or a mixture of scalariform and reticulate thickenings may be developed, as in Zamia. Mncilage ducts are common in all organs, and the pith is also remarkably rich in stored starch.

THE LESF

The alternation of rosettes of scale leaves and foliage leaves near the apex of the stem is a conspicuous feature. According to Goebel, every year or every other year a rosette of foliage leaves is expanded, in the center of which is a terminal bud

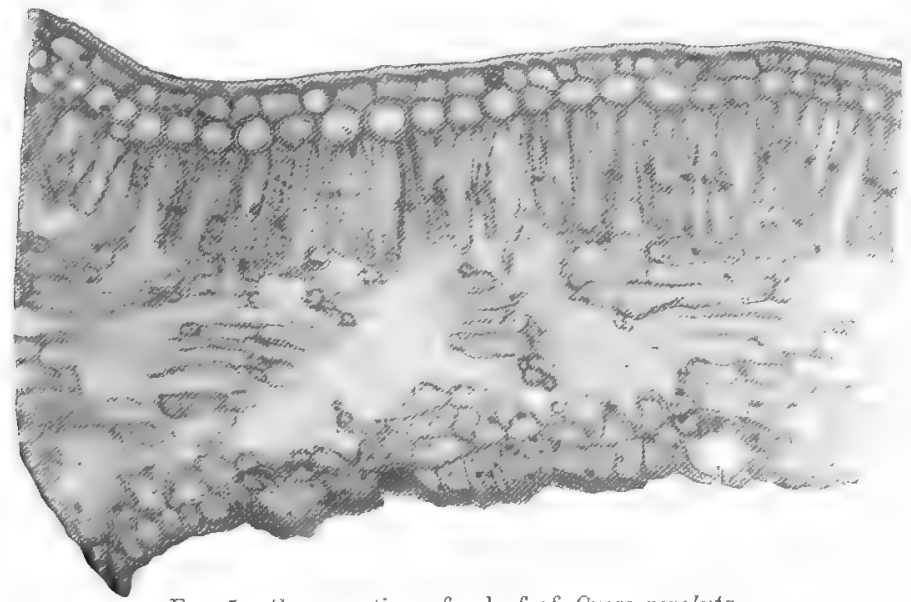

Fig. 5.-Cross section of a leaf of cycas revoluta.

invested hy numerous scale leares under whose protection a new rosette of foliage leaves slowly develops (Fig. 1). In the greenhouse material we have examined there are no such regular periods of unfolding. The altemation is still more striking when sporophylls are inclnded, scale leaves, foliage leaves, and sporophylls being the order of succession.

The seale leaves are brown and dry. The foliage leaves are pinnate and leathery, and generally develop expanded, but in 
Cycas the pinnæe are circinate, and in Zamia, Ceratozamia, and Stangeria the leaf axis is circinate. In general, two leaf traces connect the vascular systems of the stem and leaf, sometimes bending and passing almost horizontally through the cortex, sometimes, as found by Worsdell ${ }^{21}$ in Macrozamia, passing tangentially close beneath the surface for some distance and gradually turning inward to the stem system. Upon entering the leaf the two bundles break up variously, and the vein system is characterized by the comparatively small amount of anastomosing and the frequency of dichotomy, as in Encephalartos.

The anatomical structure of the leaves is quite similar to that of the broad leaves of certain Conifers (Fig. 5). The epidermis is strongly cuticularized, and the stomata occur only on the lower surface, the guard cells being deeply sunken. The leathery texture is due to a strong hypodermal development of thick-walled, almost fibrous cells, beneath which is the display of mesophyll. A distinct palisade region is organized, but the colorless middle region, in which the veins run, is peculiar. It consists of cells elongated transversely to the leaf axis and parallel with the surface, and large intercellular spaces, and may represent the "transfusion tissue " of Von Mohl. The absence of chlorophyll and the elongation of the cells has suggested a conducting region to compensate for lack of the branching and anastomosing of veins. The same structure occurs among Conifers in Sciadopitys and other broad-leaved forms; while in the needle leares the regular transfusion tissue, more definitely differentiated, is within the bundle sheath.

THE ROOT

The primary root continues as a tap root, but numerous branches and secondary roots extend in every direction, the latter often extending upward and reaching the surface. In interesting phenomenon connected with these upward rising root branches, which often spread in foltlike masses about the base of the stem in species of Cycas, Macrozamia, Ceratozamia, Dioon, and other genera, is the occurrence upon them, usually at the tip, of short "coral-like" branches, usually in clusters (Fig. 6). These peculiar hranches hare been called "tubercles," but they do not have the structure of the bodies which receive that name in certain Leguminosae, being much modified 
and tuberclelike rootlets. The apparently dichotomous branching of these bodies has led to the general statement that the secondary roots of Cycads branch dichotomously, but the dichotomy even in this case is only apparent, for the true apex, although completely checked in activity, is evident between the branches. In 1872 Reinke ${ }^{6}$ announced the presence of an endophytic alga in these tuberclelike rootlets, which he referred to Anabaena, and in 1894 Schneider ${ }^{19}$ published an account which gave much fuller details. From a recent

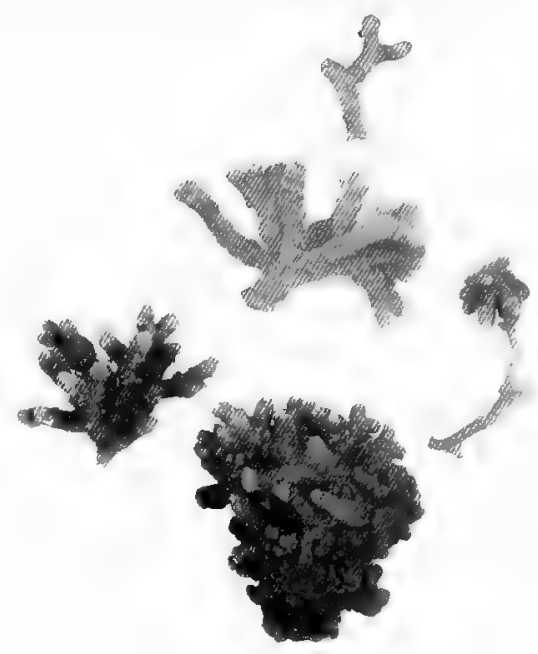

Fia. 6.-The so-called "root tubercles" of Cycas revoluta; about natural size.-After Life. paper by A. C. Life, 31 the following facts are obtained. It appears that the soil about the roots is full of low algal and

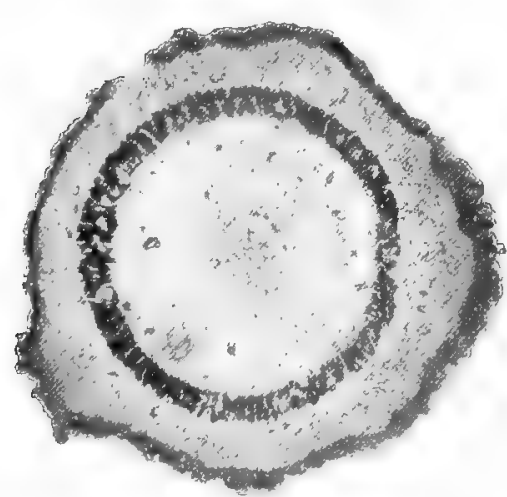

FIG. 7.-Cross section of a "root tubercle" of cycas revoluta, showing the algal zone. -After Life, tungous forms, and these forms are found also thickly clothing the roots. At the very inception of a branch bacterioid forms effect an entrance, and are found in abundance in the cells of the apical region. Presumably through their activity excrescent growth begins, and a definite zone of cortical cells is disorganized, resulting in a cortical chamber about midway in the cortex (Fig. 7). Upon the surface numerous lenticel-like openings are developed, and connect with the cortical chamber, which soon becomes filled with Nostoc 
forms. That the form is Anabaena, and that there is but a single species, are both doubtful statements. The cortical cells adjacent to the chamber send out papillate prolongations into it, giving in cross section the appearance of cells radially elongated.

That the Algae are not the inciting cause of the excrescent growth is apparent from the fact that it begins before the Algae enter, and also from the fact that in some of the tuberclelike rootlets Algae do not occur. The relations existing between the fungous and algal elements without and within the plant, and the root system, with its response in excrescent growth, lenticels, cortical chamber, and internal cortical papillæ, must be very complex.

The root cap is said by De Bary ${ }^{13}$ to arise by the splitting off of the outer layers of the periblem which covers the meristematic region, there being no true calyptrogen or dermatogen. This character is asserted by De Bary to be common to all Gymnosperms, in which they differ decidedly from Angiosperms.

\section{THE SPORE-PRODUCING MEMBERS}

THE MICROSPORANGIUN

Cycads are dioecious, and the staminate strobilus in Cycas, at least, is terminal; but its true position in the other genera, although apparently terminal, remains in doubt. Strobili may occur singly or several together, and in the latter case some at least are certainly lateral. The numerous sporophylls are arranged in a close spiral (Figs. 8, 9).

The sporophylls are persistent, often becoming very hard, and compared with those of other groups are remarkably large. In certain genera, as (ycas, Macrozamia, Ceratozamia, Stangeria, etc., they have the form of ordinary heary scales. The horizontal portion is narrowed at the insertion and broadens outward, bearing beneath the very numerous sporangia, sometimes as many as one thousand; while it is continued into a more or less vertically expanded and sterile terminal region, which is usually hairy without. In other genera, as Zamia, the horizontal and rertical portions of the sporophylls become more distinctly differentiated, the former becoming a slender stalk, the latter a peltate expansion beneath which the sporangia are clustered, as in Equisetum. The sporangia are scattered, 
or they may occur in definite groups of two to five, which may be called sori, as in Cycas, Stangeria, and Zamia (Fig. 9).

The first full account of the development of the microsporangium was published by Treub ${ }^{11}$ in 1881 , who investigated especially Zamia muricata. The latest investigation is that of Slangeria paradoxa by Lang, ${ }^{23}$ who has confirmed Treub's results in a general way, and has cleared up certain points which were doubtful.

The first indication of a sporangium is the differentiation of a hypodermal plate of cells (four in Stangeria), which constitutes the archesporium (Fig. 10). This archesporium has been homologized with the hypodermal plate of cells which appears in the development of the microsporangia of heterosporous Pteridophytes. It should be remembered, however, that the periblem always gives rise to the archespori$u m$, and that this region, in the absence of a dermatogen, is superficial in the Pteridophytes. It would seem to follow, therefore, that a true homology would regard the archesporium as superficial in Pteridophytes and hypodermal in Spermatophytes. In presenting Treub's results for Zamia, in which the archesporium is spoken of as a hypodermal group of cells, Grobel ${ }^{16}$ re-

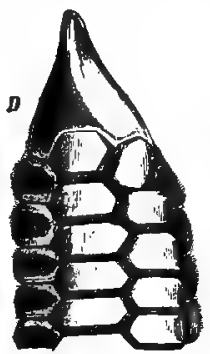

$B$
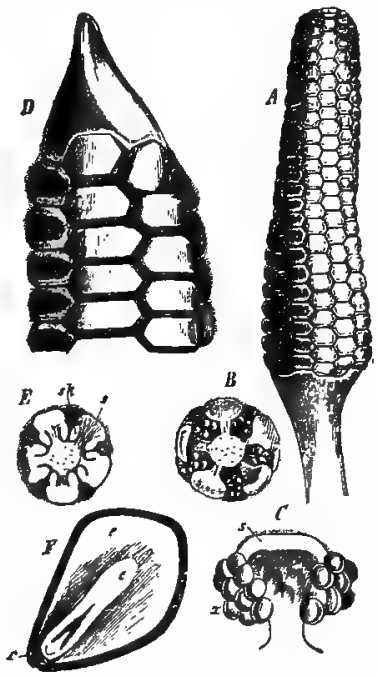

FIG.8.-Zamiamuricata: $A$, staminate strobilus, two thirds natural size; $B$, transverse section of $A ; C$, single peltate stamen showing attachment of sporangia ; $D$, upper part of orulate strobilus, two thirds natural size; $E$, transverse section of $D ; F$, longitudinal section of a ripe seed.-After $\mathrm{K}_{\mathrm{AR}-}$ STEN. marks that "there is without doubt a unicellular archesporium." In Stangeria, however, Lang was unable to trace the plate of four cells to a single one, and a one-celled archesporium for the microsporangia of Cycads still remains to be proved. Each cell of the archesporial plate divides by a periclinal wall into a tabular outer and a larger inner cell (Fig. 10). The outer daughter plate is sterile, and there is no evidence that it contributes to the sporogenous tissue, as in some Pteridophytes. It is com- 
monly spoken of as the "primary tapetum," but since it does not always give rise to the tapetum it would seem better to refer to it as primary wall cells of the sporangium. By continued

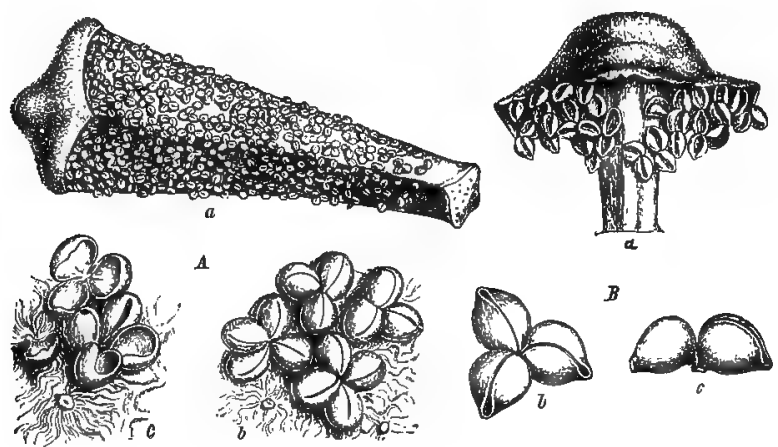

FIG. 9.-Microsporophylls of Cyeads: A, Cycas circinalis; a, entire sporophyll, showing sporangia on under surface; $b$, four groups of sporangia; $c$, same as $b$, after the pollen has been shed. $B$, Zamia integrifolia; $\alpha$, entire sporophyll $; b$ and $c$, clusters of sporangia.- $A b$ and $A c$ after BLUME, the other illustrations after RichuRD.

periclinal divisions a wall consisting of three to six layers (Stangeria) of cells is organized beneath the epidermis.

The larger cells of the inner daughter plate of the first division of the archesporial cells are the primary sporogenous cells (Fig. 10), which by division organize a large sporogenous mass. Lang states that in Stangeria, after a consilerable mass of sporogenous cells is formed, the tapetum is organized by the sporogenous tissue, either by eutting off peripheral tabular cells or by direct conversion of the peripheral cells. If this be true, the functional tapetum is derived from sporogenous rather than wall tissue. The tapetal cells are distinguished in the usual way by their size and deeply staining contents, and in a single layer completely invest the sporogenous mass. The tapetum persists as a distinct layer, but its walls disappear, and its nuclei often fragment. In its development two of the adjacent wall layers are disorganized and appear as a thin band about it, contributing of their material to the tapetum, and in this sense functioning as a tapetum.

With the complote organization of the tapetum division in the sporogenoins tissne ceases, and the cells become mother cells. Tapetal work, which seems to be merely the contribution of 
nutrition to functioning mother cells by those which are adjacent, whether they be morphologically wall cells, sporogenous cells, or even other mother cells, in Cycads is participated in also by some of the mother cells, especially those next to the distinctly organized tapetal layer. The functional mother cells become isolated, and with their complete organization the history of the sporophyte ends, the mother cells entering upon that more or less prolonged resting period preparatory to the reduction division and the beginning of the gametophyte.

The sporangia dehisce by means of a slit which extends from the base along the side away from the sporophyll and ends in a peculiar group of cells at the apex, whose morphological sig-

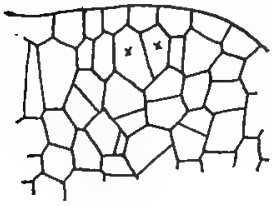

$A$

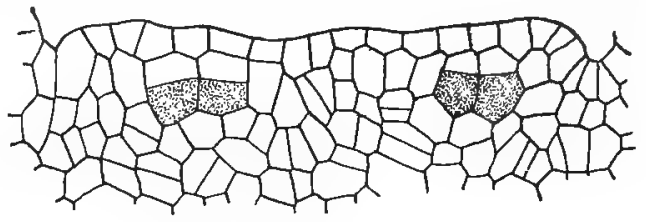

$B$
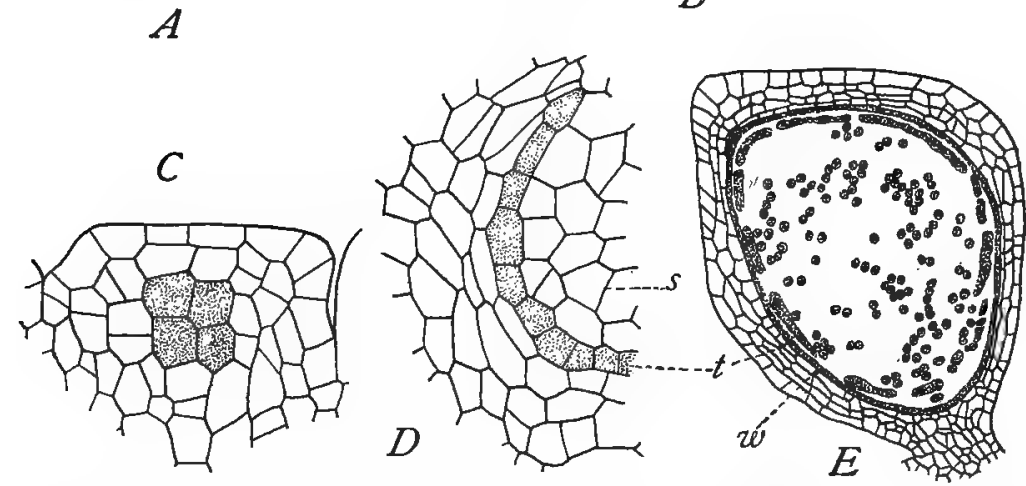

FIG. 10.-Stangeria paradoxa, showing development of microsporangium: $A$, section showing two of the four cells forming the archesporial plate; $B$, each cell of the plate has divided into an inner primary sporogenous cell (shaded) and an outer primary wall cell; $C$, a more advanced stage; $D$, a.still more advanced stage, showing the tapetum (shaded) and the sporogenous cells $(s) ; E$, a mature sporangium containing microspores, showing the tapetum $(t)$ and the crushed cells of the wall $(w)$ : $A-D, \times 266 ; E, \times 66 .-$ After LaNG.

nificance is in question. The arrangement of thin and thick walled regions in the sporangium wall, and the mechanism of dehiscence, are said to be essentially as found in Angiopteris. 
It is of interest to note that numerous stomata are found on the sporangium wall of Ceratozamia, Encephalartos, and Stanyeria, and doubtless in other genera. They are found on the wall which is opposite to the slit of dehiscence-that is, toward the sporophyll. Stomata also occur upon pollen saes of certain Angiospermis, but so far as recorded not unon the sporangia of Pteridophytes.

The development of the sporangia, their large ontput of spores, their arrangement in sori, their several-layered wall, and their dehiscence, are all characters suggestive of Marattiaceac; while the chief resemblance to Angiosperms is found in the liypodernal archesporimm.

\section{TIE MEGASPORANGIUM}

In most cases a definite ovulate strobilus is organized, which is terminal in (yeas, and possibly so in the other genera (Figs. 11, 12, 13). In Cycas the axis of the strobilus continues

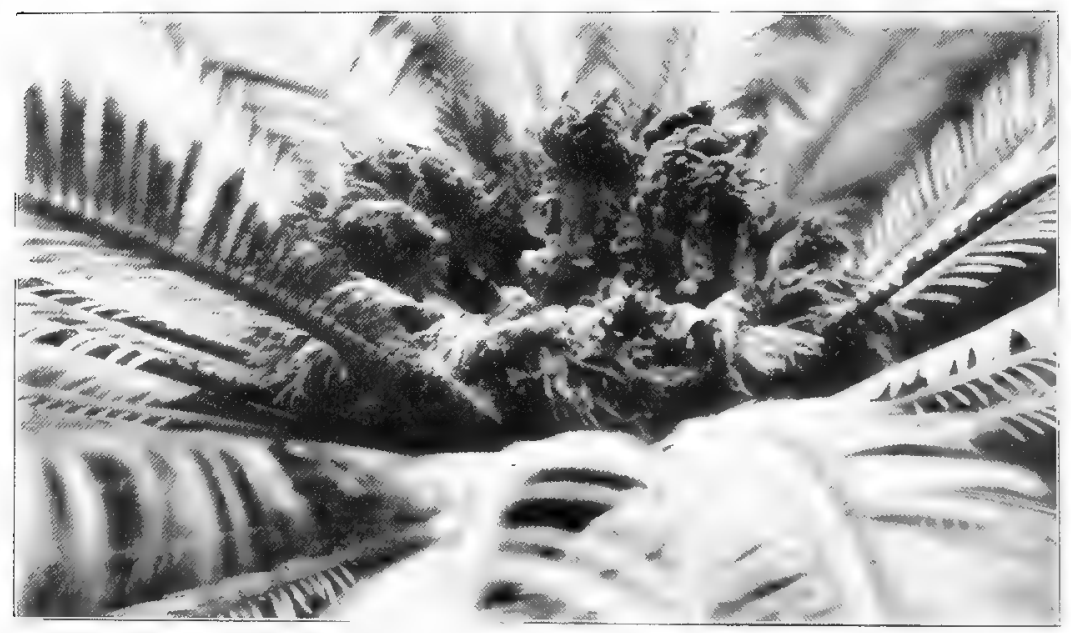

Fin 11.-Cyeros romlutu, ovulate strobilus,-From photograph taken in Lincoln Park, chicagro.

growth after the seeds have been formed, produces foliage leaves, and finally organizes another strobilus. In all other eases, including the staminate strobilus of Cycas, a strobilus stops the growth of the axis. The size of the ovulate strobilus 
of Cycads is worthy of note. In the parks of Chicago we obtained a strobilus of Dioon edule which measured 30 centimeters in height and 20 centimeters in dianeter; and one of Cycas revoluta which measured 50 centimeters in height, and about the same in diameter.

In Cycas the sporophylls resemble the foliage leaves in general form (Fig. 14), the strobilus appearing as a rosette of much smaller and yellowish leaves. An interesting transition may be traced from the leaflike sporophyll of Cycas revoluta to such specialized ones as those of Zamia or Ceratozamia (Figs. 14, 15, 16). In the sporophylls of Cycas revoluta the upper pinna are prominent, but the lowest ones, usually three on each side, are replaced by sporangia. In Cycas circinalis the upper sterile pinne are much reduced; while in Cycas Normanbyana the terminal portion of

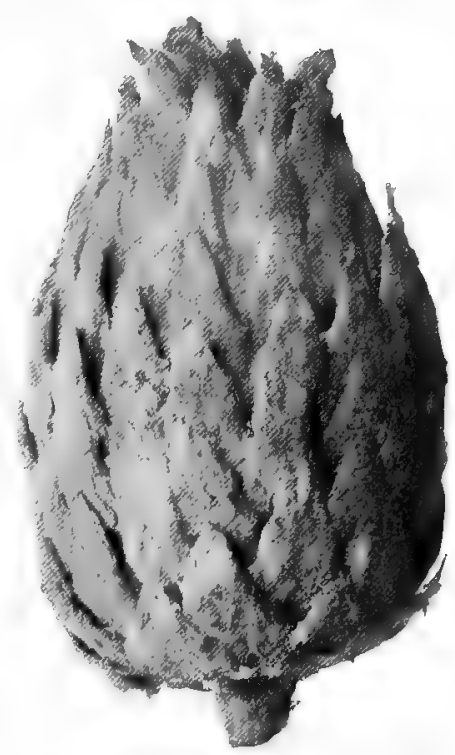

FIG. 12. Dinon edule, ovulate strobi1us; surface view; $\times 1 / 8$ - From photograph taken in Linenln P'ark, Chicago.

the sporophyll is merely toothed, the lowest pair of teeth being. replaced by sporangia. In Dioon and Encephalartos the sterile portion is still leaflike, but it is entire, and a pair of sporangia occupy a basal position; while in Zamia and Ceratozamia the sterile tip has become a peltate expansion, and leneath it is the pair of sporangia.

Investigations in reference to the development of the megasporangium have been incidental to a study of the embryo sac structures. Important among these contributions have been those of Warming ${ }^{8,9}$ on Cycas in 1877 and 1879; of Treub ${ }^{11,14}$ on Ceratozamia and Zamia in 1881 and 1884; and most recently of Lang 29 on Stangeria paradoxa. The autbors have also had the privilege of looking over material of Z amia kindly supplien by Mr. H. J. Webber. From these accounts, and from personal observation, the general facts seem to be as follows: 
The furst indication of a megasporangium is the differentiation of a group of sporogenous cells immediately beneath the epidermis. It is not a hypodermal plate, as in the microsporangium, but a hypodemal mass of considerable extent. Whether this group represents the archesporium, or whether it can be traced back to a few-celled or even to a one-celled archesporium, is still in doubt. Our impression is that there is a many-celled archesporinm. Following the differentiation of sporogenous tissue, the exterior sterile cells begin to divide rapidly, organizing the large sterile apical region of the nucellus. Abont this there develops a very thick integument with a long and narrow micropyle.

By means of this development of the exterior sterile tissue the sporogenous tissue becomes deeply placed in the nucellus,

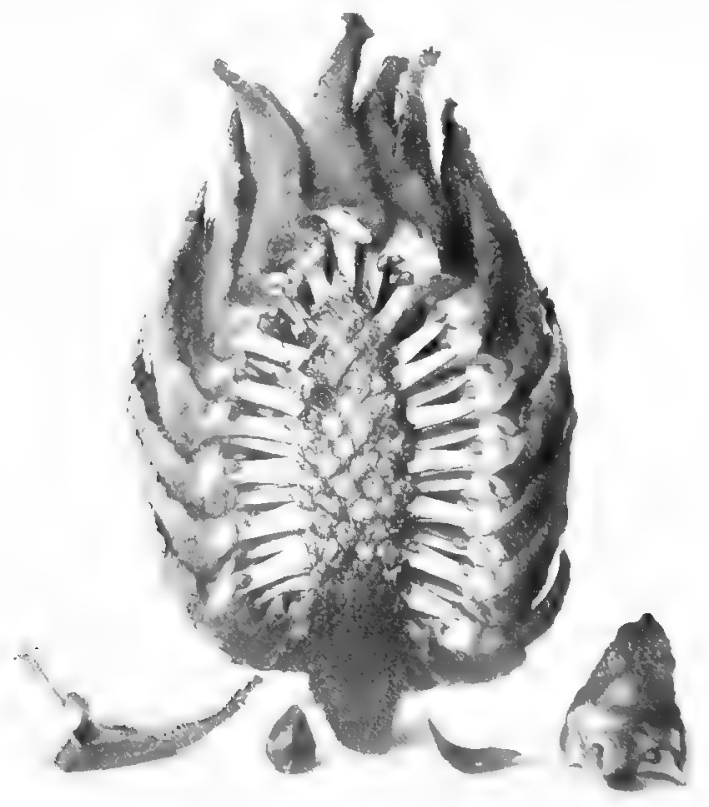

Fio. 1s-Dioon edule, sectional vew of strobilus represented in Fig. 10.

appearing alunost at its very base. In the sporogenous tissue menally one centrally placed cell shows its selection for functioning by enlareing at the expense of adjacent cells. From its subsequent behavior it seems that this enlarging cell is the 
mother cell, which closes the history of the sporophyte in this direction, and later through a reduction division begins the gametophyte generation.

Lang observed in Stangeria that about this mother cell and its product a persistent layer of the sporogenous tissue

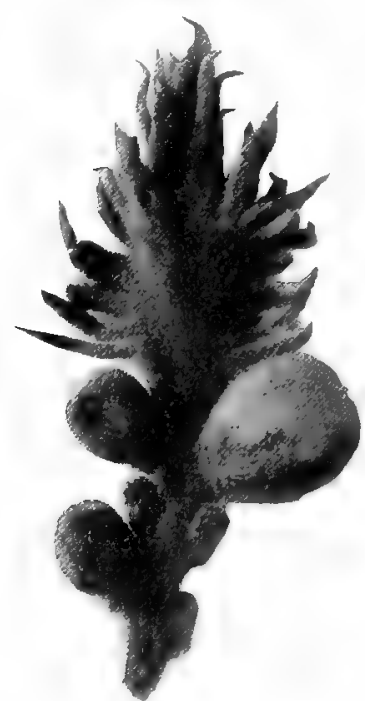

Fic. 14.-Cycts revoluta, ovulate sporophyll; one half natural size.-From photograph taken in Washington Park, Chicago.
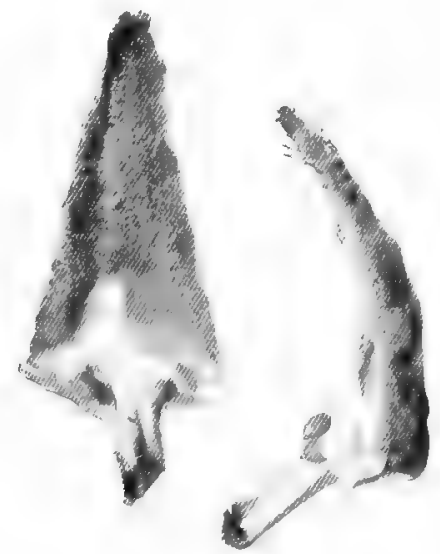

FIG. 15.Dioon edule, ovulate sporophylls from strobilus shown in Fig. 12; one half natural size.

organizes, apparently functioning as a tapetum. Whether a definite layer be organized or not, the adjacent cells continue to contribute nutrition to the mother cell and its functioning spore.

During these changes in the sporogenous tissue, the apex of the nucellus develops a more or less prominent beaklike process which projects into the micropyle (Fig. 17). The cell walls in this beak region become firm, and the whole structure forms a persistent cap, very noticeable in Cycads, in Ginkgo, and in such fossil forms as the Cordaitales and Bennettitales. Within this firm beak the pollen chamber is organized, which may be narrow or broad, but in any event is able to contain numerous pollen grains, one or two dozen having been observed in a single pollen chamber of Zamia. 
Between the base of the beak and the wall of the embryo sac the nucellar tissue is loose, and at the time of the development
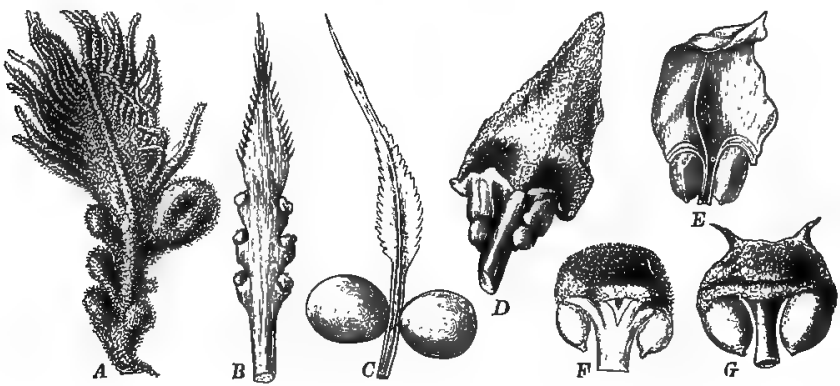

Fra. 16.-Ovulate sporophylls of various Cycads: $A, C y c a s$ revoluta; $B, C y c a s$ cirrinalis; C, Cycas Normanbyana; D, Dioon edule; E, Encephalartos Preissii; F. Zamia integrifolia; $G$, Ceratozamia Mexicana.-A, after SACHS; $C$, after F. VoN MULxER; $E$, after Miquel; $F$, after Righard ; $B, D, G$, drawn for Engler and Prantl's Nat. Pflanzenfum., from which the entire plate is taken.

of the pollen tubes this whole region of the nucellus disorganizes, leaving more or less of a cavity between the pollen chamber and the embryo sac. Into this cavity numerous pollen tubes are often seen dangling from the pollen chamber (Fig. 18), a

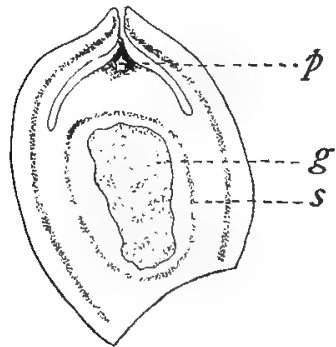

F'Ia. 17.-Stangeria paradoxa, longitudinal section of ovule, $\times 7: q$, embryo sic containing endosperm; $s$, layer of "sporogenous tissue" around the embryo sac; $p$, pollen chamber:-After LANG.

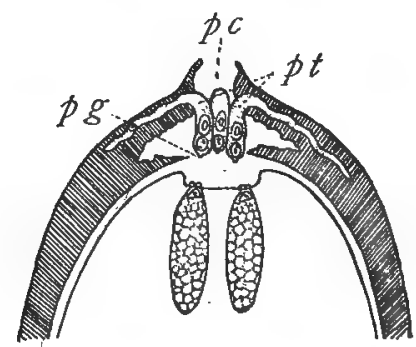

FIa. 18.-Zamia integrifolia; longitudinal section of upper end of nucellus, showing pollen tubes growing down into the arehegonial chamber: $p t$, pollen tubes; $p c$, pollen chamber; $p q$, remnant of pollen grain.-After WeBBER.

fact especially evident when one lifts off the caplike nucellar beak, which from the disorganization of the tissue beneath becomes quite loose. 


\section{THE GAMETOPHYTES}

\section{THE FEMAXE GAXETOPHYTE}

The gametophyte generation begins with the reduction division of the enlarged mother cell which lies deeply imbedded in the nucellus and surrounded by more or less sporogenous tissue which does not function as such. According to Treub ${ }^{11}$ and Lang, ${ }^{29}$ in ('eratozamia and Stangeria the transverse division of the mother cell results in a row of three cells (Fig. 19), which may be called potential megaspores, the lowest of which becomes the functional megaspore. Whether this is true of all Cycads or not remains to be seen. The selected megaspore enlarges rapidly at the expense of the two functionless megaspores, disorganizing them as well as a varying amount of adjacent tissue. The outer wall of the megaspore is said to become cutinized in Cycas, and this may be true of other genera as well. In any event, it suggests derivation from forms in which the spores are discharged.

The germination of the megaspore and the development of the female gametophyte was first published in any detail by

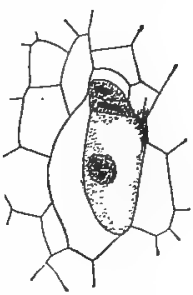

$A$

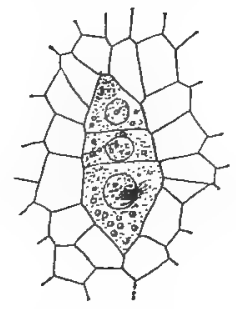

$B$

Fra. 19.-Development of the megaspore: $A$, Stangeria paradoxa, showing the functional megaspore enlarging at the expense of two functionless megaspores, $\times 250 ; B$, Ceratozamia longifolia, showing the three potential megaspores, the lowest beginning to enlarge, $\times 266 .-A$, after LaNG; $B$, after Treub. Warming, ${ }^{8}{ }^{9}$ Cycas circinalis being the form studied. Additional incidental testimony has been given by Treub, ${ }^{11}$ by Ikeno $^{28}$ in his study of Cycas revoluta, and by $\mathrm{Lang}^{29}$ in his study of Stangeria paradoxa. It is often stated in a general way that the development of the endosperm resembles that in selaginella and Isoetes, but since our knowledge of the development in these forms has been obtained by putting together fragments of information, such a statement does not represent any very exact knowledge. Unpublished results obtained by Miss F. M. Lyon with Selaginella show that something more than inference from fragments is needed. So far 
as the information goes, the sequence of events seems to be as follows:

The nucleus of the megaspore divides, and free nuclear division continues until a number of nuclei are formed, all of the divisions being simultaneous, as evidenced by the fact that all the nuclei in the embryo sac show the same karyokinetic phase. Early in these divisions the free nuclei pass to the wall of the sac and become imbedded in a parietal cytoplasmic layer, in which position the subsequent free nuclear divisions are effected. This was the earliest stage of the endosperm observed by Ilkeno, who traced the subsequent stages in considerable detail. As the nuclei continue to divide, walls begin to appear, and a parietal tissue is organized which gradually develops into and fills up the central cavity of the embryo sac. In this advance of tissue into the central region of the sac Ilkeno confirms the statement of Mlle. Sokolowa ${ }^{10}$ in reference to the development of endosperm in various Conifers, that the endosperm cells which are growing into the carity of the sac have no walls on the inner sicle. During the progress of endosperm development the embryo sac continues to enlarge, encroaching extensively upon the surrounding nucellar tissue. Warming reports that in the case of Cycas circinalis, if fertilization does not occur, the endosperm continues to grow, protrudes through the micropyle, and being thus exposed to light develops chlorophyll.

The development of the archegonium has been traced in great detail by Ikeno ${ }^{28}$ in Cycas revoluta, and in the main confirms the more general accounts of previous observers. His results are as follows: Soon after pollination (about July 1st in Japan), two to six (mostly three, sometimes eight or more) peripheral cells toward the micropyle become distinguishable from their fellows by their greater size and less decply staining contents, and are the archegonium initials (Fig. $20, A, a$ ), a condition which lasts but a few days. The second period of development extends from the appearance of a periclinal wall in the initial cell to the cutting off of the rentral canal cell, and lasts over three months. By means of the periclinal wall the initial cell is divided into an outer primary nect. cell and an inner central cell (Fig. 20, $B$ ). The former divides once by an anticlinal wall, forming a two-celled neck, as in Ginkgo. In 
Cycas circinalis Treub ${ }^{11}$ once or twice saw a transverse division of one of the neck cells.

The central cell is the only remnant of the "axial row" of the lower Archegoniates, true neck canal cells having been eliminated from the history of the archegonium. The great

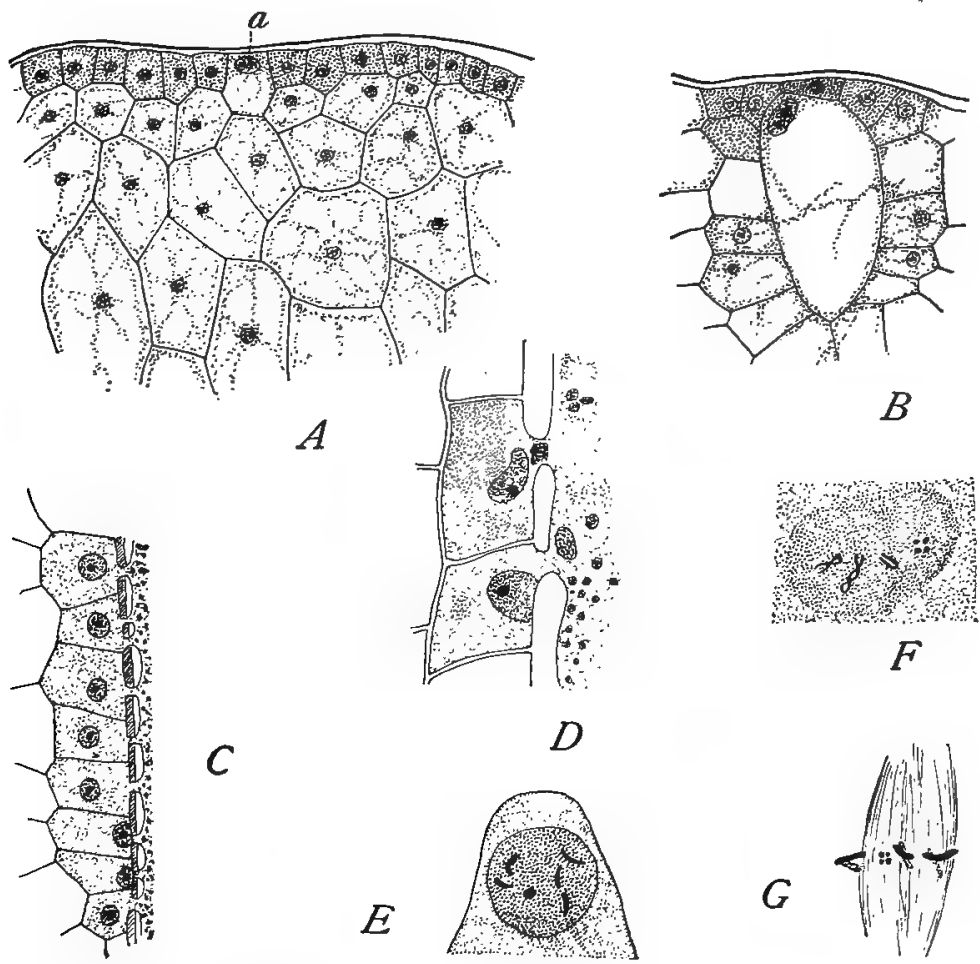

Fra. 20.-Cycas revoluta, development of arehegonium: A, upper part of endosperm, showing an archegonium initial $(a) ; B$, young archegonium, showing neck cell and central cell; $C$, a portion of the lnyer of jacket cells surrounding the central cell, showing the eytoplasmic connections; $D$, two cells of the jacket layer, showing the passage of nuclear material into the central cell; $E, F, G$, successive stages in the mitosis concerned in cutting off the ventral canal cell : $A-C, \times 200 ; D-G, \times$ about 500.-After IkENo.

enlargement of the central cell and of its nucleus, during the three months of organization, received special attention from Ikeno, who explains the source of the large supply of nutritive material needed. About the central cell the adjacent endosperm cells are organized into a definite jacketlike layer (Fig. 
$20, C, D)$. These cells have dense cytoplasm and larger nuclei, but the very thick cellulose wall toward the central cell is pierced by pores through which cytoplasmic threads connect with the cytoplasm of the central cell. This continuity of cytoplasm between the jacket cells and the central cell in Cycads was demonstrated by Goroschankin, ${ }^{12}$ and is confirmed by Ikeno. In connection with his work on the embryogeny of Cycas circinalis, Treub ${ }^{11,14}$ noted the heavy and pitted wall bounding the central cell, and really demonstrated the continuity of the cytoplasm through it. Before the archegonium has reached its full development the nuclei of the jacket cells show a delicate chromatin network, but after a time they become homogeneous, showing no differentiated structure except the nucleolus. The contents of the jacket cells, nuclei and all, now pass through the pores into the central cell, which thus receives an abundant supply of nutritive material (Fig. 20, C,D). The nucleus of the central cell, at first very small, grows during the three months until it reaches the great size of 75 to $120 \mu$ in diameter. At first it has a finely granular chromatin network, but suddenly condenses, just as the nuclei of the wall cells, and shows no nuclear structure excepting the nucleolus. Ikeno calls attention to the fact that this process of nutrition recalls that of many animals, in which it has been proved that dissolved nutrient material passes from the follicle cells to the egg.

The third period in the preparation of the archegonium consists of the formation of the ventral canal cell, which takes place at the end of September, immediately before fertilization, and lasts for a very short time. The central cell thrusts a beaklike process between the neck cells, a spindle is organized at once, and the small ventral canal cell is cut off rapidly, but for a long time is distinguishable as a cap resting upon the ventral cell. After the cutting off of the ventral canal cell the nucleus of the large ventral cell passes to the central region of the organizing egg.

It is of interest to note that the occurrence of a ventral canil cell in cycads remained in doubt until its demnustration by Ikeno ${ }^{20}$ in 1896 in Cycas revoluta, confirmed in 1897 by Webber ${ }^{27}$ for Zamia integrifolia. Strasburger ${ }^{7}$ in 1876 observed such a coll in Cycres sphaerien: Warming ${ }^{8}$ described it in 157 in Ceratozamia robusta, but two years later ${ }^{9}$ withdrew his con- 
clusion; Treub ${ }^{14}$ in 1884 stated positively that there is no such cell in Cycas circinalis. Until Ilkeno's demonstration in 1896, therefore, the absence of such a cell in the Cycads was generally accepted.

It is important to note that the development of a group of archegonia checks the growth of the vegetative tissue of the gametophyte in that region, and the adjacent regions continuing to grow, the archegonial region is left at the bottom of a pitlike depression, which may be called the archegonial chanber, or " endosperm cavity," as Warming has called it. This chamber is full of liquid during fertilization, and at the bottom of it the necks of the archegonia open (Fig. 18). Occasionally two of these chambers have been observed, each with its group of archegonia.

\section{THE MALE GAMETOPHYTE}

The male gametophyte begins with the reduction division of the spore mother cell, which seems to have received no special attention in Cycads. The organization of the tetrad by successive division, accompanied by a peculiar chambering of the mother cell, has been described in detail by Juranyi ${ }^{5}$ for Ceratozamia longifolia, and by Treub ${ }^{11}$ for Zamia muricata (Fig. 21). With the appearance of the nuclear plate in the first division, a ring of thickening develops upon the outer surface of the wall of the mother cell in the plane of the plate. Proceeding from this ring of thickening, a heavy wall develops between the two daughter cells. Juranyi thought that the nuclear plate disappears, and that the heavy wall is formed by growth at the free inner edge of the ring. Treub dissents from this view, and, although he could not demonstrate the fact on account of the abundant starch grains, thinks that the nuclear plate persists and gradually thickens, the thick-
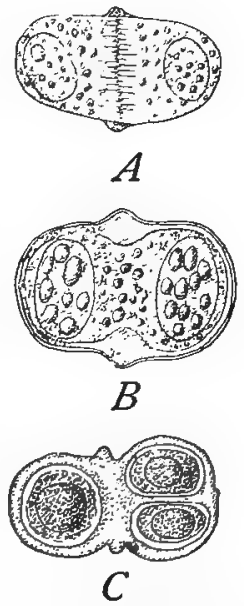

FIg. 21.-Zamia muricata; successive stages in the development of the microspores: $A$ and $B, \times 596 ; C, \times 466$. After Treus. ening proceeding from the peripheral ring toward the center. The latter view seems to be the more reasonable one. The two 
daughter cells divide in the usual way, and heavy walls are again formed. Within this heavy four-celled and often lobed case the microspores are organized.

The first comparatively full account of the germination of the microspore seems to have been that of Juranyi ${ }^{5}$ for Ceratozamia longifolia. In 1896 , in a preliminary paper, ${ }^{20}$ fol-
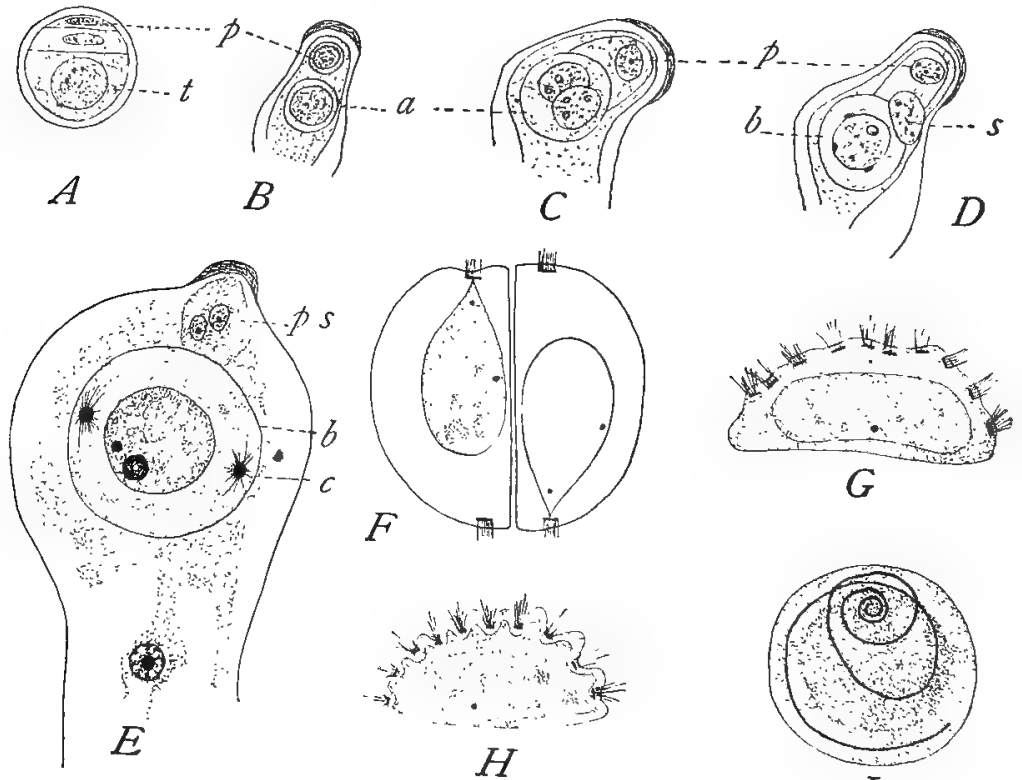

Fia. 22.-Cycas revoluta, development of tho ciliated male cell : 1, male gametophyte of three cells, vegetative or "prothallial " cell $(p)$, generative cell, and tube cell $(t)$, $\times 500 ; B$, the generative cell $(a)$ rounded off, $\times 200 ; C$, the generative cell $(a)$ showing division of nucleus into stalk and body nuclei, $\times 500 ; D$, first appearance of blepharoplasts in enlarging body cell (b), and diminishing stalk nuclens $(s), \times 500$; $E$, body cell (b) shortly before division, showing well-developed blepharoplasts $(c)$, $\times 750 ; F$, the two male cells resulting from the division of the bolly cell, showing the beaked nuclei, $\times 200 ; G, I I, I$, later stages in the development of the ciliated male cell, $\times$ 200.-After Inrso.

lowed by the full paper $2 s$ in 1898 , Ikeno presented a detailed account for Cycas revoluta: while in $1897 \mathrm{~W}^{r} \mathrm{ebloc}{ }^{25,26,27}$ published his results for Zamia integrifolia. One of the authors has also examined Mr. Webber's preparations. The sequence of events is as follows (Fig. 2:, 23 ):

A small lenticular cell is cut off and persists, and as it seems 
to represent the vegetative tissue of the gametophyte it is often called a "prothallial cell." There is no evidence from the literature or plates referred to above that an evanescent vegetative cell precedes the persistent one, although the occurrence of such a cell is possible, and it should be looked for. At this early stage, therefore, the male gametophyte consists of a single small vegetative cell and a large cell which we regard as the antheridium initial. The latter cell divides unequally, and a second small cell is organized which is in contact with the vegetative cell. This division differentiates the sterile and the fertile series of the antheridium. The larger, or sterile cell, seems to represent the antheridial
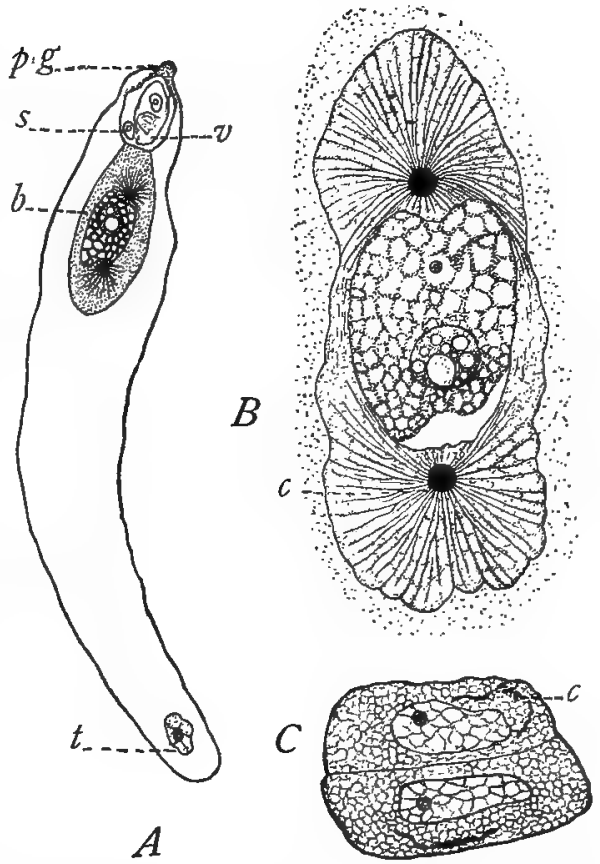

Fic. 23.-Zamia integrifolia: $A$, pollen tube, showing remnant of pollen grain $(p g)$, stalk cell $(s)$, body cell $(b)$, vegetative cell $(v)$, and tube nucleus $(t), \times 80 ; B$, the body cell represented in $A$, showing the two blepharoplasts (c) surrounded by radiations, $\times 366 ; C$, division of body cell, showing the two immature male cells and the fragmented blepharoplasts $(c), \times 133 .-$ After WaBBER.

wall, but since its chief function is to develop the pollen tube it may be called the tube cell, and its nucleus the tube nucleus. These are the "vegetative cell" and the "vegetative nucleus" of ordinary terminology, but these phrases are more applicable to the so-called "prothallial cell" and its nuclens.

The smaller cell formed by the division of the antheridial initial is the primary spermatogenous cell, called in botanical literature either the generative cell or " antheridial cell." Webber has observed in Zamia an interesting relation between the 
vegetative cell and the generative cell, the former actively pushing in the wall of the latter until there is an appearance of one cell within another. It is at this stage that Ikeno observed the tube pushing into the nucellus and carrying with it the tube nucleus, after which the generative cell divides to form the two cells which have been called the stalk cell and the body cell. In Cycas, as in Ginkgo, the plane of this division is at right angles to the former planes of division, so that the stalk and body cells lie side by side and are equally free to develop further. In $Z$ amia, however, as usually in Pinus, the plane is parallel with the former ones, and the two cells lie fore and aft-that is, in a lineal series with the vegetative cell. It is this position which seems to have suggested the name stalk cell for the one next to the vegetative cell.

The stalk cell functions no further, but the body cell enters upon the history which is of greatest interest in the investigations of Ikeno and Webber, paralleled by Hirase for Ginkgo. Bodies appear, named blepharoplasts by $\mathrm{W}^{\mathrm{r}} \mathrm{ebber},{ }^{27}$ one at each pole of the nucleus, their final position being in an axis at right angles to the long axis of the pollen tube. The origin of these bodies is unknown, but nothing to suggest them occurs in any other cells of the plant. In their polar position they develop remarkably in size, reaching a diameter of 10 to $15 \mu$ in Cycas and 18 to $20 \mu$ in Zamia, and giving off fibers which seem to join with the very evident cytoplasmic network.

In the meantime the pollen tube, containing the tube nucleus, has been growing through the nuccllar tissue, and branching more or less freely, but apparently not so profusely as in Ginkgo. It seems to function only as an absorbing organ, for the male cells never pass into it. A short time before fertilization the tube nucleus passes back through the tube and consorts with the stalk and body cells, after which the body cell divides.

This division occurs in a plane at right angles to the axis connecting the much-enlarged blepharoplasts, and results in the formation of two male cells, morphologically sperm mother cells, which lie side by side, their frec faces rounder, and cach with a single blepharoplast. The blepharoplast breaks up into a group of granules, and in Cycas, according to Ikeno, a beaklike process which remains closely associated with the blepharoplast granules is put out from the nucleus. The clongating beak and granules 
approach the free wall and trace a widening spiral of five or six turns, which involves about one half of the cell wall. In this process the granules are organized into a spiral band lying very near or against the wall. The blepharoplast band then puts out numerous short cilia which pierce the wall of the male cell, on whose surface a spiral groove is developed. During this process the nuclear beak disappears, and the visible connection between nucleus and band is cut off. The final surface appearance of the male cell is that of an oval cell, broad and naked behind, spirally grooved in its anterior half, and with many short motile cilia emerging from the groove. It should be noted that Zamia, so far as Webber's preparations show, gives no evidence of a nuclear beak associated with the organization of the ciliated band, but it seems to move independently toward the wall and assumes the spiral position.

During the organization of the cilia the nucleus begins to enlarge at the expense of the cytoplasm, until finally it attains remarkable relative dimensions, bulging between the coils of the band, so that it becomes spirally grooved, and is covered only by a thin mantle of cytoplasm. The ciliated band is formed before the two sister cells separate, and Webber has observed the pair swimming while still connected. When mature, this ciliated cell is visible to the naked eye in Zamia, its longer axis measuring 258 to $332 \mu$, its shorter axis being a little less. In Ginkgo Hirasé gives the dimensions as $82 \mu$ by $49 \mu$; and Ikeno reports that the dimensions in Cycas are somewhat larger, but evidently not to be compared with those in Zamia.

It is these ciliated cells which have been called spermatozoids or antherozoids, and such they are physiologically. Morphologically, however, they are sperm mother cells which do not organize sperms internally, but themselves pass over directly into sperms, a fact which seems true of all Spermatophytes. Morphologically, therefore, they are identical with the so-called male cells of all ordinary Seed plants, but are peculiar in becoming ciliated. The contrast with Pteridophytes, in which each mother cell organizes an internal ciliated sperm and discharges it, is sharp. The resemblance between Cycads and Pteridophytes is not in the morphological character of the cell which functions as a sperm, in which the Cycads resemble the other Seed plants, but in the fact that it is ciliated. 
It is helpful to contrast the spermatogenous series in Cycads, which is the same as in other Gymnosperms, with that in such a Pteridophyte as Isoetes. The sequence may be expressed diagrammatically (Fig. 24), the terminology of the Gymnosperms being used.

At one time it seemed to us desirable to homologize this series, if possible, with spermatogenesis as observed in animals,

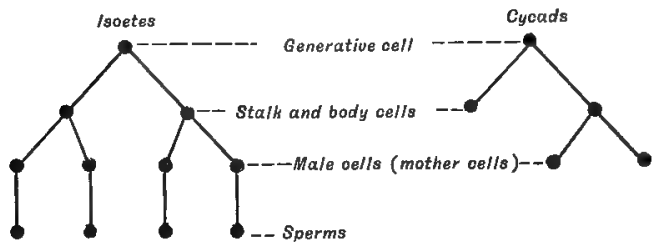

FIG. 24.-Diagrum contrasting spermatogenesis in Cycads and Isoetes. and to use the same terminology. Upon further investigation, however, we have concluded that such an attempt is at present impossible. In animals there is no defined alternation of generations, and in their spermatogenesis the reduction division is an important feature, so that merely matching generation with generation in the spermatogenesis of the two series would probably be very far from indicating any true homologies.

It should be said that ciliated male cells have been actually observed as yet in but three species of Cycads: in Cycas revoluta by Ikeno, in Zamia integrifolia by Webber, and in Stangeria paradoxa by Lang.

\section{FERTILIZATION}

Immediately after the male cells have become transformed into ciliated sperms, the events intimately connected with fertilization begin to occur. The more or less extensive pollen tube systell, which has been penetrating the loose nucellar tissue capping the embry sac, is abandoned, the tissue becomes disorganized and collapses, and the gametophyte structures within the pollen chamber are brought sensibly nearer the emlryo sac. The pollen tube region in connection with the pollen grain then begins to derelop, and this end of the tube, eontaining the tube nucleus and sperms, is turned toward the embryo sac, its end (apped by the old microspore wall (Fig. 16). Upon reaching the wall of the mbryo sac over? ying the archegonial chamber resorption of walls probably occurs, but in any event the 
turgid end of the tube bursts and discharges its contents into the chamber, in whose liquid numerous sperms have been observed swimming. As the archegonium necks open into the bottom of this chamber, the sperms swim to them and pass down to the egg. Webber observed in Zamia as many as four sperms in a single neck.

As the sperm passes into the cytoplasm of the egg Ikeno and Webber both observed that the cytoplasmic mantle with its ciliated band slips off, and is left in the peripheral region of the egg cytoplasm, the sperm nucleus moving alone toward the egg nucleus. Ikeno states that shortly before the entrance of the sperm the egg nucleus develops a cuplike depression, into which the sperm nucleus is received. In any event, the latter imbeds itself in the former, and, according to Webber, remains distinct for a long time (Fig. 25). Ikeno claims that the sperm nucleus "dissolves" within the egg nucleus, and that all nuclear organization is lost, lout it seems more likely that the same condition obtains as in Conifers, a condition which might very easily have escaped observation.

The prominent development of the pollen tube as an absorbing organ suggests a question as to its original significance. Associated with ciliated sperms, which have devel-
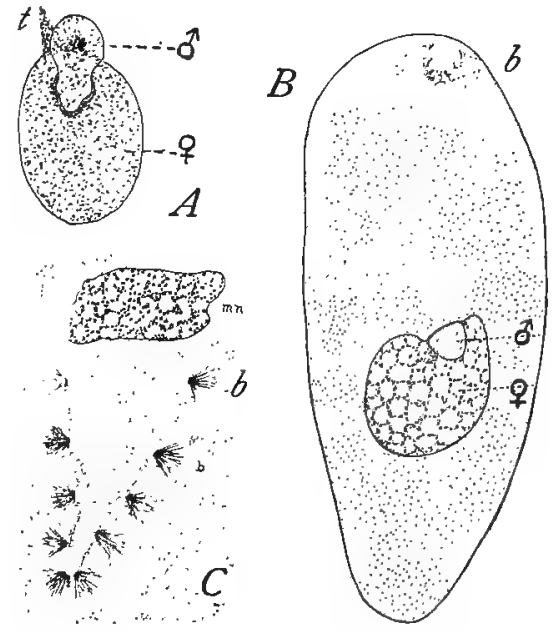

Fig. 25.-Fertilization in Cycads: $A$, fusion of the nuelei in cyctes revoluta, $t$ indicating the so-called trophoplasmic substance: $B$, fusion of the nuclei in Zamia integrifolia, $b$ being the discarded ciliated band, $\times 20 ; C$, the male nucleus (mn) of Zamia integrifolia after slipping from the cytoplasnic sheath and ciliated band, $\times 66 .-A$, after Irevo; $B$ and $C$, after W EBBER.

oped in alose proximity to the egg, the function of the tube as a sperm carrier is reduced to a minimum, and in fact does not seem to occur in the Cycads. It is an interesting question, therefore, whether the pollen tube originated as an absorbing 
organ and later became used as a sperm carrier, or whether the reverse is true. It would seem natural to think of the Cycad condition as the more primitive one.

\section{THE EMBRYO}

The first comparatively full account of the development of the embryo is that given by Treub ${ }^{14}$ for Cycas circinalis, and this account has been confirmed by fragmentary observations since. The account given by Ikeno ${ }^{28}$ for Cycas revoluta agrees

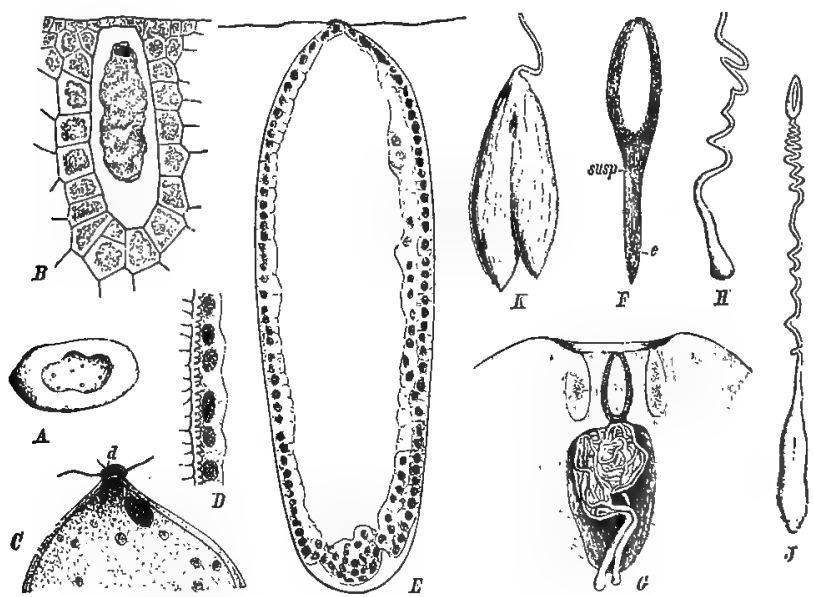

Fia. 26.-Cyoas circinalis, development of the embryo: $A$, an ovule from above, showing the openings of the necks of several archegonia, $\times 2 / 8 ; B$, longitudinal section of an archegonium, $\times 73 ; C$, a fertilized egg, showing several free nuclei, $\times 24$; $D$, free nuclei of the proembryo, showing parietal placing, $\times 36 ; E, a$ young proembryo, $\times 15 ; F$. a young embryo, showing saclike proembryo, suspensor ( $s u s p$ ), and embryo proper $(e), \times 6 ; G$, longitudinal section of seed containing two embryos, two thirds natural size; $H$, embryo with suspensor, $\times 11 / 8 ; J$, a more advanced embryo, two thirds natural size; $K$, a mature embryo.-After TREDB (from Engler and Prantl's Nat. Pflanzenfam.).

in every particular with Treub's, and fills in certain gaps. There is still almost entirely lacking any knowledge of the development of the embryo itself. The embryogeny shows three distinct phases as follows (Fig. 26$)$ :

1. Development of Proembryo.-This name was applied by Treub to the intrasporic derelopment. The oospore en1larges, continuing to receive supplies of nutrition from the adjacent tissue. The first change observed by Treub was the pres- 
ence of numerous free nuclei distributed through the cytoplasm. He naturally inferred that these were derived by repeated nuclear division from the oospore nucleus. Ikeno observed the first division of this nucleus, and has called attention to certain peculiarities connected with it-peculiarities which are chiefly suggestive in being found also in Ginkgo and in Pinus. The first nuclear spindle is the largest one which appears during free nuclear division, and its axis is always inclined to the long axis of the archegonium. Whether this position is significant or not remains to be seen, but the fact that it is also observed in Ginkgo and Pinus suggests that it is worthy of record. The fibers of this primary spindle do not converge as they do in all subsequent ones. As a consequence, this spindle is very broad in outline, really rectangular, while all subsequent spindles are distinctly bipolar. A further point of interest in connection with this spindle is that there are no centrosomes, or centrosomelike bodies, or even polar radiations connected with it. It would seem, therefore, that there is no organ which might be regarded as the lineal descendant of the blepharoplast, which was so prominent in the sperm series. The subsequent bipolar spindles show the ordinary radiations, but no bodies at the poles.

Free nuclear division proceeds with rapidity and in simultaneous fashion until the nuclei become very abundant. Ikeno calls attention to the fact that at this time the structure of the cytoplasm of the central region changes. It becomes at first vacnolate, and then completely disorganizes, the nuclei imbedded in it sharing the same fate. The remaining cytoplasm becomes parietal, massing somewhat towards the bottom of the spore. In this parietal layer the nuclei are imbedded, being equidistant from one another and forming usually a single layer, but at the base they are more massed. In this position the nuclei continue to divide and reach large numbers, when cell walls begin to appear. An interesting fact in connection with this division of nuclei, when in the parietal position, is that some of the free nuclei which are nearest the neck end of the oospore divide amitotically, but this tendency seldom reaches into the deeper regions. As a result of this development the proembryo becomes a sac, somewhat thickened at the base, but with the wall composed of one or at most two layers of cells. At this point the work of Ikeno stops, and beyond it Treub gives very little detail. 
2. Development of Suspensor.-At the beginning of the second period of development the cavity of the saclike proembryo fills up with tissue somewhat at the base, but is never obliterated. This second period, however, is chiefly devoted to the development of the suspensor, which is effected by the elongation of cells in the mass at the base of the spore which lie immediately behind the terminal group. These cells, by elongating and dividing, develop a remarkably long and tortuous and massive suspensor, which has never been observed to branch or to give rise to more than a single embryo. The suspensors emerge from the archegonium region in a fascicle, and, imbedded in the endosperm, form a considerable cavity by the disorganization of the adjacent cells. The tips of the suspensors bearing the groups of cells destined to form the embryos are imbedded in the tissues beyond this cavity. The suspensor is quite persistent, remaining attached to the mature embryo, and suspensor coils with abortive embryos may be seen even in ripe seeds.

3. Development of Embryo.-Nothing of morphological significance is known in reference to the development of the embryo. The earliest stages figured show an embryo far advanced. In its complete state the embryo shows two cotyledons, but concerning the origin of these cotyledons, or of the stem tip, or of the root tip, we have no information.

THE SEED

The seed becomes plumlike, the testa dereloping from the thick integument in two layers, the outer fleshy, the inner stony. The riew that these two very distinct layers of the testa may represent two integuments, which have been merged into what appears to be a single very thick integument, will be referred to later, in connection with the other groups. In Cycas revoluta, and probably in the other Cycads, the development of the seed does not depend upon fertilization, for with or without pollination there is the same increase in size and development of the two layers of the testa. In germination the cotyledons are said to he hypogean and closely coherent at the apex, as in Ginkgo, but no definite work in seed germination among Cycads seems to have been done. 


\section{LITERATURE CITED}

1. Brongniart, A. Recherches sur l'organisation des tiges des $\mathrm{Cy}$ cadées. Ann. Sci. Nat. I. 16: 389-402. pls. 20-22. 1829.

2. Von MoHL, Hugo. Ueber den Bau des Cycadeen-stammes. Abh. der K. b. Acad. zu München 1: - 1832. Republished and revised in Vermischte Schriften 195-211. 1845,

3. Miquel, F. A. W. Monographia Cycadearum. 1841.

4. Metrenius, G. H. Beiträge zur Anatomie der Cycadeen. Abh. der K. Sächs. Gesells. der wiss. 7: 565-608. pls. 1-5. 1861.

5. Jurany, L. Bau und Entwick. des Pollens bei Ceratozamia longifolia Miq. Jabrb. f. wiss. Bot. 8: 382-400. pls. 31-34. 1872.

6. Reinke, J. Parasitische Anabaena in Wurzelen der Cycadeen. Gött. Nachr. 107. 1872.

7. Strasburger, E. Ueber Zellbildung und Zelltheilung. 1876.

8. WARMing, E. Recherches et remarques sur les Cycadées. Oversigter over d. K. D. Vidensk. Selsk. Forh. 1877.

9. WaRMING, E. Contributions à l'histoire naturelle des Cycadées. Ibid. 1879.

10. Sokolowa, Mlle. C. Naissance de l'endosperme dans le sac embryonnaire de quelques Gymnospermes. Moscou. 1880.

11. Treub, M. Recherches sur les Cycadées. Ann. Jard. Bot. Buit. 2: 32-53. pls. 1-\%. 1881 (date of reprint, volume date being 1885).

12. Goroschankin, J. Zur Kenntniss der Corpuscula bei den Gymnospermen. Bot. Zeit. 41: 825-831. pl. 7 A. 1883.

13. De BARY, A. Comparative Anatomy of the Vegetative Organs of the Phanerogams and Ferns. English translation. 1884.

14. TReUb, M. Recherches sur les Cycadées. 3. Embryogenie du Cycas circinalis. Ann. Jard. Bot. Buit. 4: 1-11. pls. 1-3. 1884.

15. Costantin and Morot. Sur l'origine des faisceaux libéro-ligneux supernuméraires dans la tige des Cycadées. Bull. Soc. Bot. France 32: 173. 1885. Ref. Bot. Centralbl. 24: 101-102. 1885.

16. Goesed, K. Outlines of Classification and Special Morphology. English translation. 316. 1887.

17. Solms-Ladbach, H. Graf zo. Die Sprossfolge der Stangeria und der übrigen Cycadeen. Bot. Zeit. 48: 177-187, 193-199, 209-215, 225-230. 1890.

18. Strasburger, E. Histologisehe Beiträge 3: 151. 1891.

19. SCHNEIDER, A. Mutualistic Symbiosis of Algae and Bacteria with Cycas revoluta. Bot. Gaz. 19: 25-32. pl. 3. 1894.

20. Ikeno, S. Das Spermatozoid von Cycas revoluta. Bot. Mag. Tokyo 10: 367-368. 1896.

21. WorSDELL, W. C. Anatomy of Stems of Macrozamia compared with that of other Genera of Cycadeae. Ann. Bot. 10: 601-620. pls. 27-28. 1896. 
22. Ikeno, S. Vorläufige Mittheilung über die Spermatozoiden bei Cycas revoluta. Bot. Centralbl. 69: 1-3. 1897.

23. LANG, W. H. Studies in the Development and Morphology of Cycadean Sporangia. I. The Microsporangia of Stangeria paradoxa. Ann. Bot. 11: 421-438. pl. 2\%. 1897.

24. Sсотт, D. H. The Anatomical Characters presented by the Peduncles of Cycadaceae. Ann. Bot. 11: 399-419. pls. 20-21. 1897.

25. Webber, H. J. Peculiar Structures occurring in the Pollen Tube of Zamia. Bot. Gaz. 23 : 453-459. pl. 40. 1897.

26. Webber, H. J. The Development of the Antherozoids of Zamia. Bot. Gaz. 24: 16-22. 1897.

27. Webber, H. J. Notes on the Fecundation of Zamia and the Pollen Tube Apparatus of Ginkgo. Bot. Gaz. 24: 225-235. pl. 10. 1897.

28. IxENo, S. Untersuchungen über die Entwickelung der Geschlechtsorgane und der Vorgang der Befruchtung bei Cycas reroluta. Jahrb. f. wiss. Bot. 32: 557-602. pls. 8-10. 1898.

29. Lang, W. H. Studies in the Development and Morphology of Cycadean Sporangia. II. The Ovule of Stangeria paradoxa. Ann. Bot. 14: 281-306. pls. 17-18, 1900.

30. Worsdeld, W. C. The Anatomical Structure of Bowenia spectabilis. Ann. Bot. 14: 159-160. 1900.

31. Life, A. C. The Tuberclelike Roots of Cycas revoluta. To appear in Bot. Gaz. 31: F 1901. 


\section{CHAPTER II}

\section{GINKGOALES}

Tris group is represented by a single living species, Ginkgo biloba, almost unknown in the wild state, but reported in certain forests of western China. Its extensive cultivation, however, first in China and Japan, and later in all civilized countries, has made it accessible. It was long regarded as an exceptional Conifer of the Taxus group, although its resemblances to Cycads were frequently pointed out. Recent investigation, however, has resulted in regarding this species as the only survivor of an ancient phylum which deserves to be coordinated with Cycads and Conifers. A very full general account of the species has been published recently by $A$. C. Seward and Miss J. Gowan, ${ }^{16}$ while two papers by Hirasé ${ }^{11,13}$ supply the first comparatively full account of the reproductive structures.

\section{THE VEGETATIVE ORGANS}

\section{THE STEM}

The tree has the general habit of a Conifer, with central shaft and widespreading branches (Fig. 27). It is recorded as reaching sometimes a height of more than 30 meters, with a circumference of more than 8 meters. The vascular bundles are collateral, and with a persistent primary cambium as in the Conifers, resulting in growth rings of the ordinary type. The secondary rood is composed of tracheids with bordered pits, and a characteristic double leaf trace connects the vascular system of the stem with that of the leaves. Resin ducts are abundant, both in the pith and in the cortex. Two types of branches may be distinguished, the long. shoots which are terminal and elongate rapidly, and the short shoots which are axillary and slow growing, usually bearing tufts of leaves at the summit, and corered below with old leaf scars. 


\section{THE LEAF}

The foliage leaves are very characteristic in form and venation, resembling in this regard some of the Ferns. The petiole

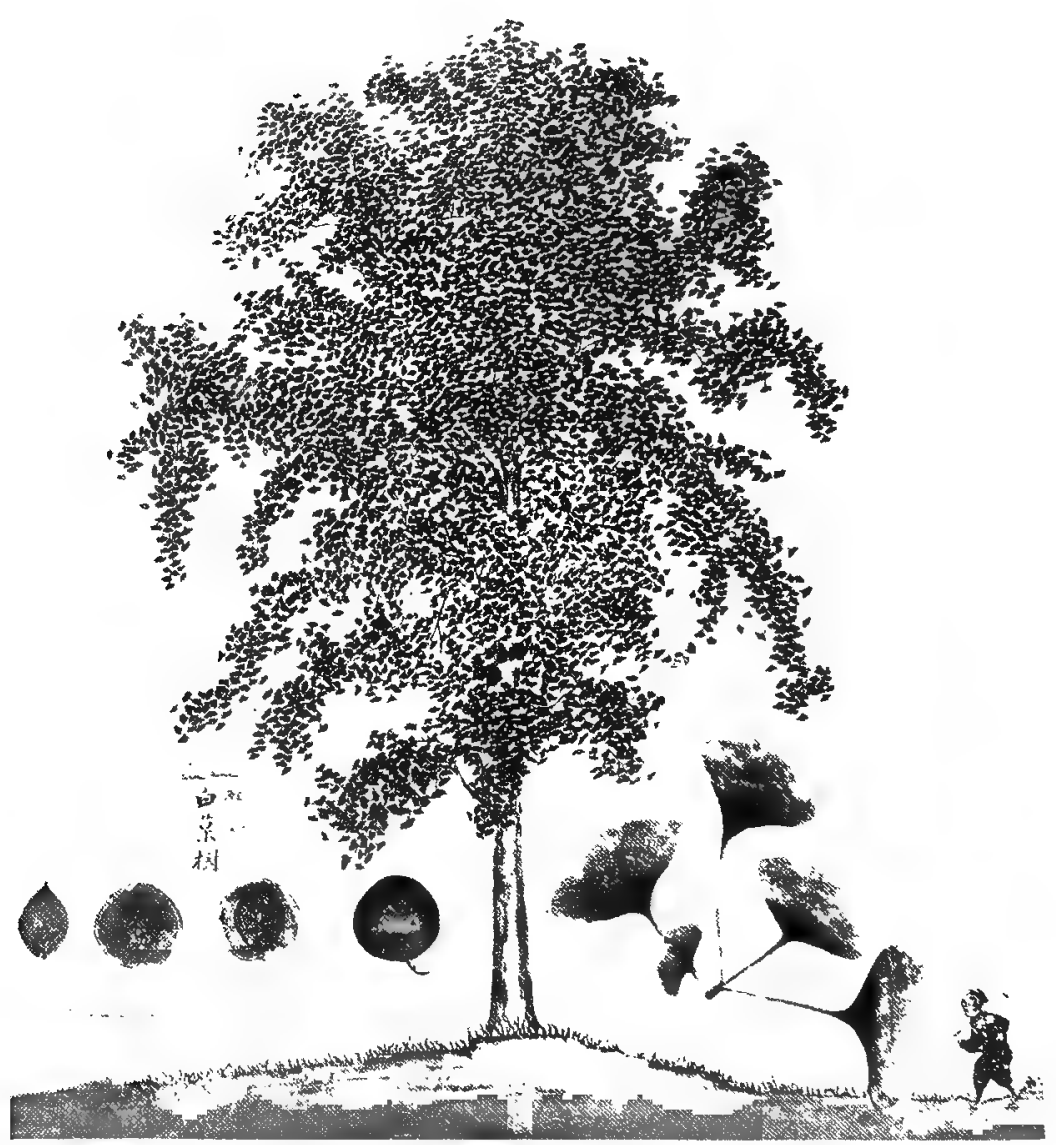

Fit. 27.-Ginkgo biloba. Taken originally from "water-color painting by a Chinese artist.-Atter SEWARD and GOWAN.

is long and slender, the blade is broadly wedge-shaped and variously lobed, and the renation is distinctly dichotomous (Figs. 
28, 29). There is great variability, however, both in size and amount of lobing.

The development of the foliage leaf has been described by Fankhauser. ${ }^{6}$ It is at first a protuberance embracing two fifths of the circumference at the stem apex. Soon a distinct emargination is developed which becomes a deep incision. During development the blade is bent over at the apex and the margins are strongly inrolled. The leaves, especially when young, are not merely deeply two-lobed, but each lobe is variously toothed or divided.

In anatomical characters the leaf resembles those of Cycads. There is developed an evident but not very thick cuticle. The stomata are restricted to the lower surface, the guard cells being somerwat below the level of the epidermis. A palisade

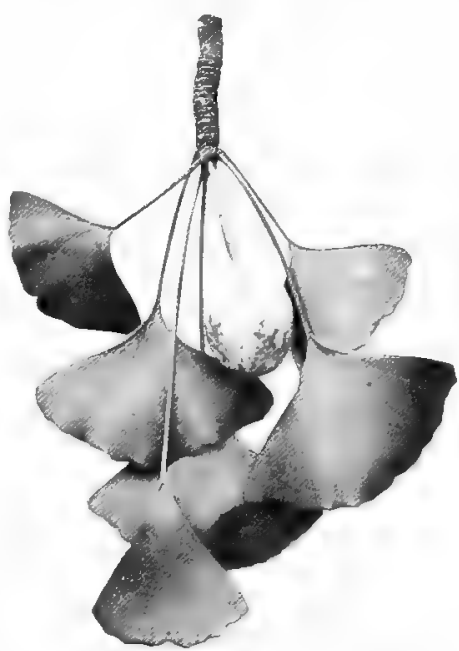

FIG. 28.-Ginkgo biloba, a cluster of leaves and a nature seed. tissue is erident, but somewhat irregular. A transfusion tissue, such as was described under the Cycads, appear's also in the

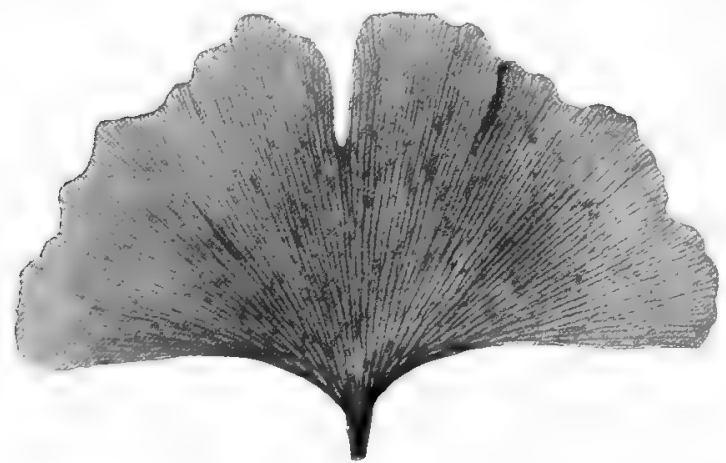

FIG. 29.-Ginkgo biloba, a single leaf, showing venation. leaves of Ginkgo, cells of the inner mesophyll elongating in a plane parallel with the leaf surface and developing numerous and prominent intercellular spaces.

The leaves are deciduous, a rare habit among Gymnosperms, being displayed in Conifers only by Larix, Taxodium distichum, and Glyptostrobus. 
THE ROOT

Some account of the anatomy of the root has been published by Van Tieghem. ${ }^{2}$ It seems that the vascular cylinder is originally a diarch, and a little later each strand divides, resulting in the formation of a tetrarch cylinder. Later, new strands come in, so that five or six alternating xylem and phloem bundles appear. Presumably the meristem of the apex shows the same peculiarities as described under Conifers.

\section{THE SPORE-PRODUCING MEMBERS}

\section{TIIE MICROSPORANGIUM}

T'he stamens occur in loose catkinlike clusters from the axils of the scale leaves dercloped at the summit of the short shoot (Fig. 30, B). It is this elongated catkinlike cluster of microsporophylls which has received the inappropriate name of the "male flower." The sporophyll has a rather long stalk and terminates in a more or less expanded knob, which may be regarded as representing the expanded sterile tip common among the Cycads. Beneath the knob the pendent sporangia are borne, usually two in number, but sometimes three, or even four. The dehiscence is by a longitudinal slit (Fig. 30,C).

There are no published details of the development of the sporangium, but there is no reason to suppose that it is different in any important way from that clescribed for the Cyeads. The mature sporangium wall consists of four to seven layers of cells, with thickening bands on the onter layers.

THE MEGLISPORANGIUMI

The structures associated with the megasporangium have given rise to much discussion. A long stalk arises from an axil of the leaves borne at the summit of a short shoot, and near its apex mostly two megasporangia are borne, only one of which functions (Fig. 30, A, E). A bout the base of each sporangium is a more or less conspicuous cup or " collar," muclu more prominent in the younger stages of the sporangium, reaching its full development very carly. Seward and Gowan ${ }^{15}$ have published a résumé of the various views hold in reference to the homologies of these structures. Briefly they are as follows: 
In 1869 Van Tieghem ${ }^{1}$ published his view that the stalk represents a petiole, and that the two ovules are determined by the two characteristic lobes of the blade. According to this view, the whole structure stands for a single carpel. Van Tieghem further sees in the collar at the base of each ovule a reduced arillus, which name of course gives no clew to its homology. In 1872 Strasburger ${ }^{3}$ published the view that the stalk is a shoot, and that the collar is the rudiment of the first pair of leaves of a secondary shoot. It would follow that the whole structure is an inflorescence bearing two flowers, and

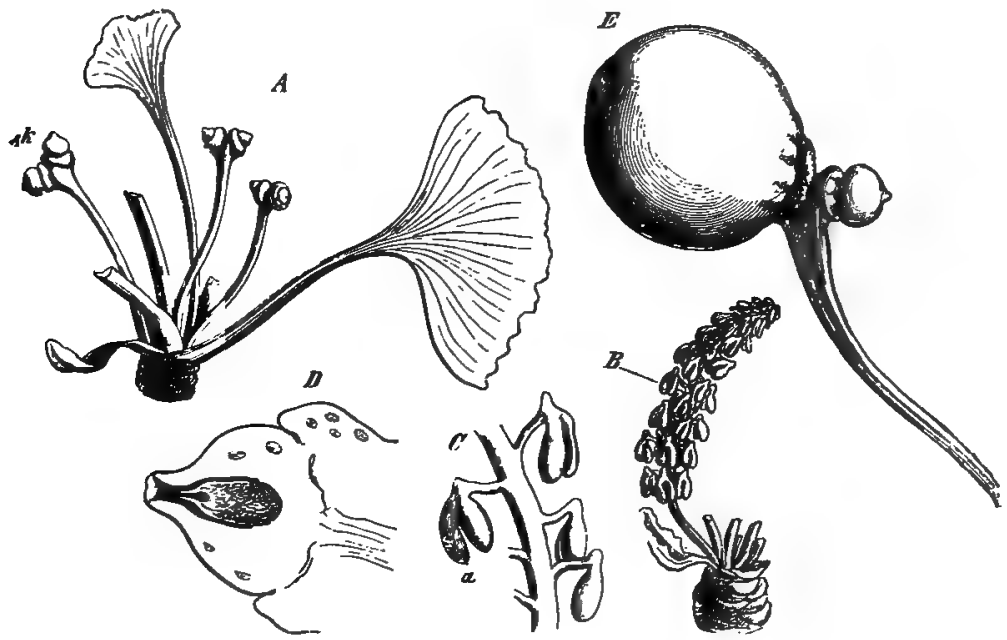

Fig. 30.-Ginkgo biloba: $A$, dwarf branch bearing leaves and young ovules; $B$, a staminate strobilus; $C$, more enlarged view of a portion of $B ; D$, longitudinal section of a young ovule; $E$, a ripe seed associated with an undeveloped ovule. $A, B, E$, natural size; $C, D$, enlarged.-After GoEBEL.

that any such structure as a carpel is suppressed. In $1879^{5}$ he modified his riew as to the character of the collar, having concluded, as Van Tieghem had thought, that it represents an arillus. He cited cases in which a stalk bore four ovules, each upon a slender stalk of its own; this of course was a strong argument in favor of the view that the whole structure represents a shoot. In 1873 Eichlex ${ }^{4}$ published his view that the collar represents an outer integument, which is not necessarily inconsistent with the preceding views that it stands for an arillus. Later ${ }^{7}$ he called the collar a rudimentary carpel, and 
regarded the two ovules as representing a single flower. In 1890 Celakovský ${ }^{8}$ published the view that the stalk is an axillary shoot bearing two or more carpels, but that each carpel is represented only by an ovule. This means that the presence of the carpel is purely theoretical. The same author ${ }^{14}$ in 1900 reaffirms this position with greater fullness of detail. In 1896 Fujii, ${ }^{12}$ after a study of abundant Japanese material, and especially taking into account numerous abnormal developments, came to the conclusion that the stalk is a shoot, usually bearing

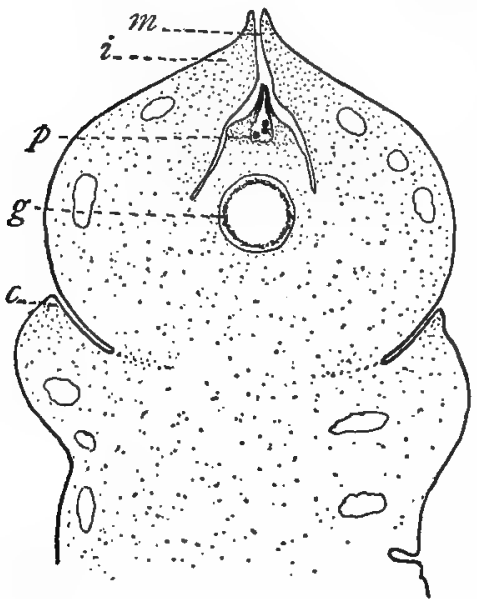

FIG. 31,-Ginkgo biloba, longitudinal section of ovule: $i$, integument; $m$, micropyle; $p$, beaked apex of nucellus, with pollen chamber containing pollen grains; $g$, embryo sac containing an early stage of the, gametophyte; $c$, the "collar"; $\times 5$. two rudimentary carpels. That the ovules are really related to carpels appears from the fact that he found them upon more or less modified foliage leaves. In other cases he found transition stages between the normal collar and blades bearing ovules, his conclusion being that the collar represents the rudimentary carpel. The short stalk which is sometimes quite evident in connection with each ovule stands, therefore, for the petiole of a megasporophyll. That the main stalk is a shoot was further evidenced by the fact that cases were found in which a stalk bore several ovules and terminated in a scaly bud. The results of Seward and Gowan's ${ }^{16}$ studies coincide with the views of Fujii. These observers have still further strengthened the position by the record of additional abnormalities.

A summary of what seems to be the most reasonable view of the homologies of the ovulate structures in Ginkgo is as follows: The main stalk represents a shoot bearing two or more carpels, and these carpels mostly occur in rudimentary form, the petiole being represented by the short stalk upon which each ovule stands, and the blade by the so-called collar.

The development of the megasporangium seems to be al- 
most identical with that in the Cycads. According to $\mathrm{Pax}^{9}$ a many-celled archesporium is differentiated. The single thick integument with a long and narrow micropyle, the large mass of sterile nucellar tissue above the single megaspore, the conspicuous and resistant nucellar beak projecting into the micropyle and containing a pollen chamber, the comparatively loose nucellar tissue between the beak and the megaspore, are all as in the Cycads (Fig. 31). Hirase ${ }^{13}$ says that the pollen chamber is organized early in May, soon after the maturing of the pollen, and that near the time of pollination it is full of liquid. $\mathrm{He}$ also observes that the chamber results from the exclusive development of the external tissue of the beak, the inner tissue thus becoming ruptured and disorganized. The changes which occur in the nucellus in connection with the development of the pollen tubes will be described under fertilization.

\section{THE GAMETOPHYTES}

THE FEMALE GAMETOPHYTE

-The development of the endosperm seems to proceed in the same way as in the Cycads, although such full details are not on record. However, the following sequence of events is the same: free nuclear division, parietal placing of free nuclei imbedded in a cytoplasmic layer, appearance of walls resulting in the organization of a tissue, and gradual growth of the parietal tissue toward the center of the sac, which it finally completely fills. During this development the sac encroaches upon the adjacent nucellar tissue, practically obliterating all of it except that which caps the sac. Hirase has made the interesting observation that about 256 free nuclei have been organized when walls begin to appear, representing eight successive nuclear divisions.

There are usually two archegonia, but sometimes a greater number has been observed. They are exactly as in the Cyeads, with two neck cells, and a central cell which develops remarkably in size and nutrient material (Fig. 34, $A-C$ ). $\mathrm{As}$ in $\mathrm{Cy}-$ carls, also, the adjacent cells of the endosperm organize a layer of jacket cells about the central cell, and a heavy wall is developed. It seems very probable that the central cell in this case receives nutritive supplies from the jacket cells through 
wall pores, as has been demonstrated in Cycads and Conifers. Just before fertilization, early in September, the small and ephemeral ventral canal cell is cut off, and the large egg is organized (Fig. 34, C). Hirasé states that about twenty weeks elapse between pollination and the maturity of the egg. It should also be noted that an archegonial chamber is developed in the endosperm, as in Cycads, though this is somewhat modified later by the remarkable development of an endosperm beak, to be described in connection with fertilization.

\section{THE MALE GAMETOPHYTE}

Our knowledge of the development of the male gametophyte of Ginkgo dates from Strasburger's account ${ }^{10}$ in 1892, much extended by the recent very complete observations of Hirasé ${ }^{13}$ (Fig. 32). From this last account the following description of the male gametophyte and of fertilization is derived.

The first division of the microspore is unequal, resulting in cutting off a small lenticular cell, which soon disorganizes and later appears merely as a cleft in the heavy spore wall. This first ephemeral cell may be regarded as a vegetative cell of the gametophyte, a vestige of the vegetative tissue of a more extensive and probably independent gametophyte. It is interesting to note that this same ephemeral cell appears in the germination of the microspores of most of the Conifers, but was not observed by either Ikeno or TTebber in the Cycads.

A second unequal division occurs, and a second small cell is cut off, which persists, and which represents a second vegetative cell (Fig. 32, $A, p$ ). This second vegetative cell is cut off in the microspore of most Conifers, but it is ephemeral like the first; while this single persistent vegetative cell appears to be the first and only one cut off in the inicrospores of Cycads. Ginkgo resembles the Conifers, therefore, in having two vegetative cells; and resembles the Creads in haring one persistent vegetative cell. It is a question whether a first ephemeral vegetative cell may not yct be detected in Cycads, thus confirming the close resemblance between these two gromps which appears in almost crery other feature of their male gametoph.tes.

After the two vegetative cells hare been cut off, the remaining large cell is what we regard as the antheridium initial, whose function is to organize the single antheridium. This cell di- 
vides uncqually, the smaller daughter cell, in contact with the persistent vegetative cell, being the primary spermatogenous cell or generative cell (Fig. 32, $B, a$ ), the larger daughter cell being the tube cell (Fig. 32, $B, t$ ). The gametophyte is in this

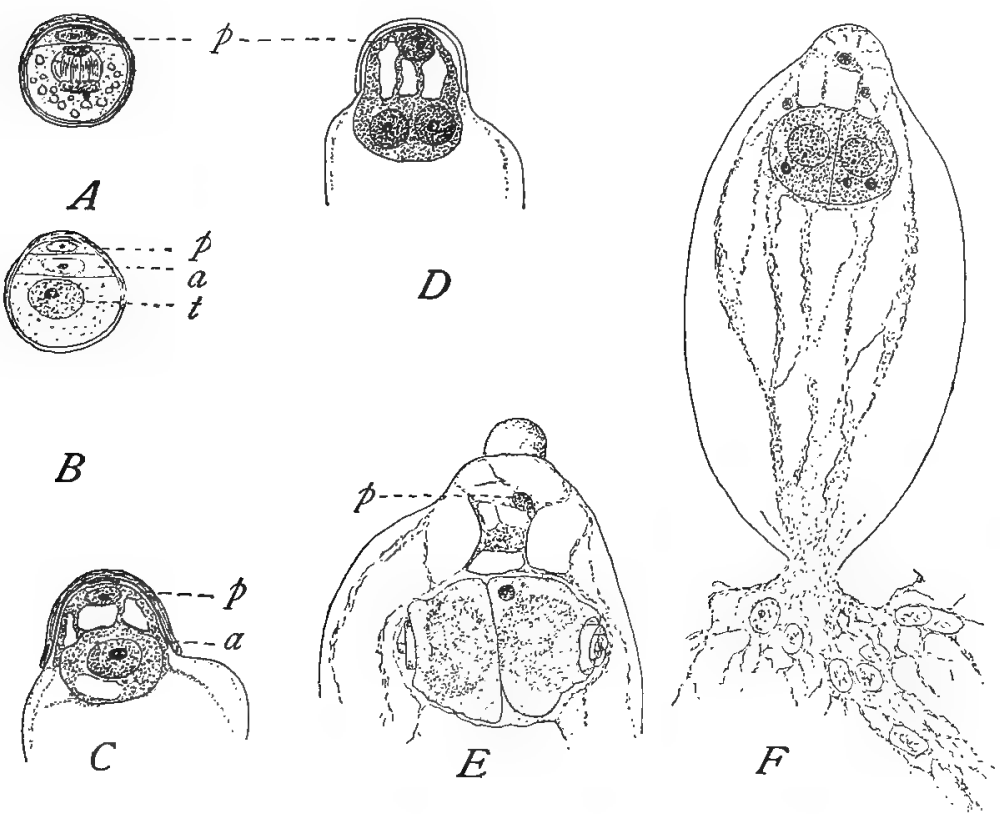

FIG. 32.-Ginkgo biloba, development of male gametophyte: $A$, pollen grain collected April 24th, showing third nuclear division and the persistent vegetative cell $(p)$, $\times 500 ; B$, a later stage, showing persistent vegetative cell $(p)$, generative cell $(a)$, and tube nueleus $(t), \times 500 ; C$, later stage, July 10 th, the generative cell almost spherical, $\times{ }^{\top} 500 ; D$, division of nucleus of generative cell into nuclei of stalk and body cells, July 11th, $\times 500 ; F$, division of the body cell, the blepharoplasts being faintly visible, $\times 120 ; E$, the two male cells produced by the body cell, September 12th, $\times$ 226.-After HirasÉ.

three-celled stage when pollination takes place, during the last of April or early in May.

From this stage on the sequence is exactly as that described for Cycas. The generative cell divides to form the stalk and body cells (Fig. 32,D), which lie side by side, only the body cell functioning further. In the body cell the two blepharoplasts (Fig. 32, $F^{\prime}$ ) appear, and division occurs, resulting in the two male cells, lying side by side, and each containing a blepharoplast. Each male cell then directly develops as a 
multiciliate sperm, the blepharoplast forming the cilia-bearing band, which a beaklike process put out by the nucleus seems to guide in organizing the spiral of about three coils.

Although this general account is the same as that given for Cycads, there are at least two differences in detail which deserve mention. Hirase states that the division of the generative cell of Ginkgo is only a nuclear division, or at least that there is no dividing wall, and that the nonfunctional nucleus is gradually thrust out of the cell by the large development of the functional nucleus. He further states that when the cilia-bearing band is about to be organized by the blepharoplast, the latter puts out a hooklike process which attaches itself to the nucleus, and following this the nuclear beak develops with the hooklike process attached to its tip. Hirasé's observations indicate that the initiative which results in the nuclear beak proceeds from the blepharoplast, while Ikeno's observation indicates that the initiative proceeds from the nucleus itself. It will be remembered that Webber observed no nuclear beak in Zamia.

The homology of these ciliated cells functioning as sperms, and the reason for not regarding them as the morphological equivalents of the multiciliate sperms of Pteridophytes, but rather the equivalents of the so-called male cells common to all Spermatophytes, are fully stated in connection with the $\mathrm{Cy}$ cads. Hirasé's figures show a wall inclosing the ciliated cell, presumably the wall of the mother cell (male cell), but no reference is made to it in the text. If this represents the real situation, it would follow that the ciliated cell in Ginkgo is morphologically a sperm, being organized within a mother cell and discharged from it. This view is clcarly supported by the recent figures and statement of Fujii, ${ }^{14}$ which represent the multiciliate sperm as distinctly organized within the mother cell and discharged from it. The details of development are so nearly identical with those in Cycas and Zamia, that it seems improbable that such an important difference could occur. If it be true that the ciliated sperm in Ginkgo is morphologically a sperm, and not mercly a ciliated mother cell, it would follow that Ginkgo is still more fernlike than was supposed, and unlike other Gymnosperms and all Angiosperms in the feature that its sperm mother cells do not function as male cells. It must be remembered that Ginkgo is a much older type than are the Cycads investigated, 
even the genus Cycas, and it is not inconceivable that this difference between a very ancient type and much more modern types may occur.

\section{FERTILIZATION}

We have reserved for this topic all of the events associated with the development of the pollen tubes, as well as the immediate act of fertilization. When the pollen grains reach the pollen chamber, about the first of May, the male gametophyte is in its three-celled stage, the cells being the persistent vegetative cell, the generative cell, and the large tube cell. The pollen chamber now begins to enlarge at the expense of the nucellar tissue beneath, carrying the grains deep into the nucellus. By the beginning of June the chamber has greatly enlarged, forming a large irregular cavity, which practically reaches the embryo sac. When the grains begin to put out their tubes, the opening to the pollen chamber becomes closed and remains so, the surrounding tissue becoming brown and forming a solid beak which long persists as a cap on the sac. The deep placed grains, carried by the enlarging chamber well below the beak, send out their tubes in every direction into the adjacent nucellar tissue, but chiefly away from the embryo sac, and often directly toward the beak. Into these young tubes the tube nuclei pass, and remain there as long as the tube system is developing.

About the beginning of July the tubes have penetrated the nucellar tissue more deeply and branch freely, the tube nucleus remaining where a tube begins to branch. This extensive system of branching tubes seems to function only as an absorbing system, as in the Cycads. At this stage the generative cell has the appearance of being pushed away from contact with the vegetative cell, on account of the development of vacuoles in the latter (Fig. 32, D); it increases very much in size, its nucleus keeping pace with it; and these relative positions are maintained until just before fertilization, which occurs about ten weeks later.

About the middle of July the nucleus of the generative cell divides rapidly, forming two daughter nuclei which represent the stalk and body cells. One of these nuclei enlarges very much, and comes to occupy a central position in the cell, crowding the other aside into the space between the generative cell and the vegetative cell. In this way the body cell is organized. 
At the end of July the body cell increases still more in size, becoming rich in contents, and its nucleus becoming very large. At this stage the blepharoplasts appear, and finally assume their polar positions at the extremities of the long axis of the ellipsoidal nucleus. This stage persists for three weeks-that is, until the third week before fertilization.

At the beginning of August the tube nucleus begins to pass back to the grain end of the tube, which it reaches in about two weeks, consorting with the body cell, or with the male cells, until fertilization. During this retreat of the tube nucleus and abandonment of the absorbing tube system, the endosperm begins to develop a beak between the two archegonia. Hirase suggests that its significance is to be explained by the fact that the

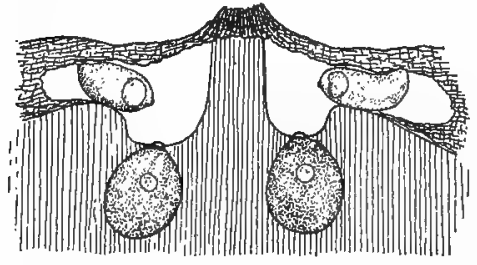

Fis. 33.-G Ginkgo biloba, upper part of female gametophyte, showing two archegonia, the beaklike process of the endosperm supporting the remains of the nucellus, and the swollen tips of two pollen tubes, September 9 th, $\times 24$ - After Hirasí.

tissue between the nucellar beak and the embryo sac has been broken down by the - deepening of the pollen chamber and by the absorptive work of the pollen-tube system, and that the heavy beak settles down upon the sac. In about two weeks the endosperm beak looks like a small column, with its summit against the nucellar beak, "like a tent supported by its center pole," in the shelter of which there is freedom for the final processes connected with fertilization. Pressure upon the grain ends of the pollen tubes which happen to lie under "the tent" is thus avoided, and these ends become very turgid and are directed toward the near-Iying archegonia (Fig. 33).

During the third week before fertilization-that is, about the last of August-the body cell begins division, and the ciliated male cells are organized. The swollen tip of the pollen tube, capped by the old wall of the pollen grain, now contains in a group the two male cells, the tube nucleus, and the vegetative cell, together with whatever may remain of the stalk cell. At the time of fertilization the capped tip of the tube turns toward the archegonial chamber and discharges the contents into it. The exact position of the sac wall in relation to 
the archegonial chamber after the development of the endosperm beak is not made clear in Hirasé's account, which seems to imply that the way is open to the archegonial chamber. In any event, the sperms reach the chamber, and in it Hirase has
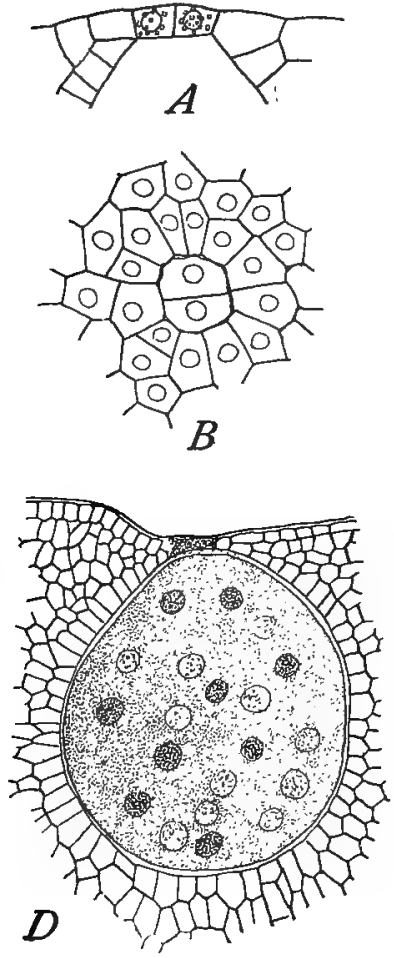
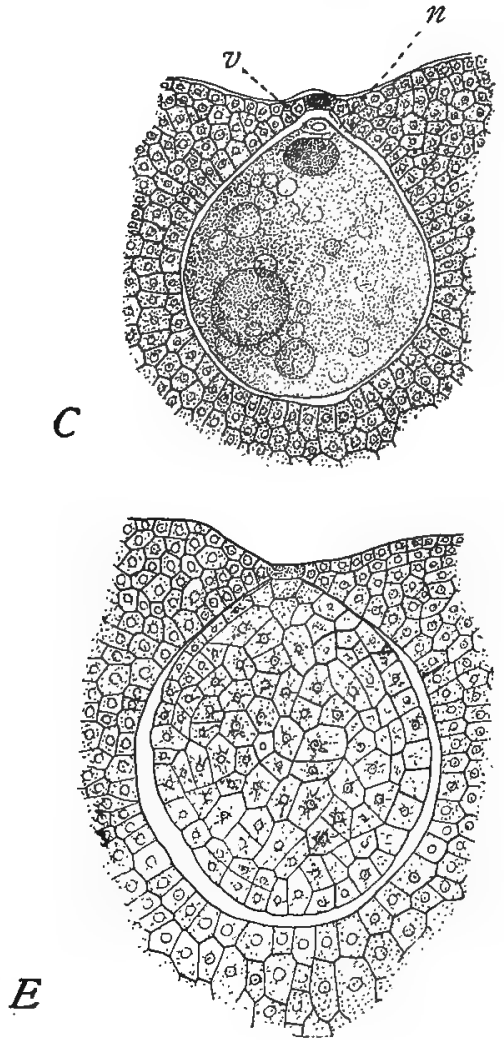

Fia. 34.-Ginkgo biloba: $A$, longitudinal section of the neck of the arehegonium, $\times 160$; $B$, transverse section of the same, $\times 160 ; C$, archegonium shortly before fertilization, showing ventral canal cell $(v)$ and egg nucleus $(n), \times 66 ; D$, free nuclei resulting from the first nuclear divisions of the oospore, $\times 66 ; E$, later stage, showing the compact tissue of the embryo tilling the oospore, $\times 66$.-After STrasburgER.

observed them swimming. The entrance of sperms into the archegonia follows, and fertilization is effected.

The statement has been usual that fertilization does not occur until the ripe ovules have fallen. While this may be true frequently, Hirase found that some seeds, at least, con- 
tain embryos while still attached, a fact which we have been able to verify in our own experience.

\section{THE EMBRYO}

Although the embryo of Ginkgo is exceptional among Gymnosperms, and of great interest, the details of its development

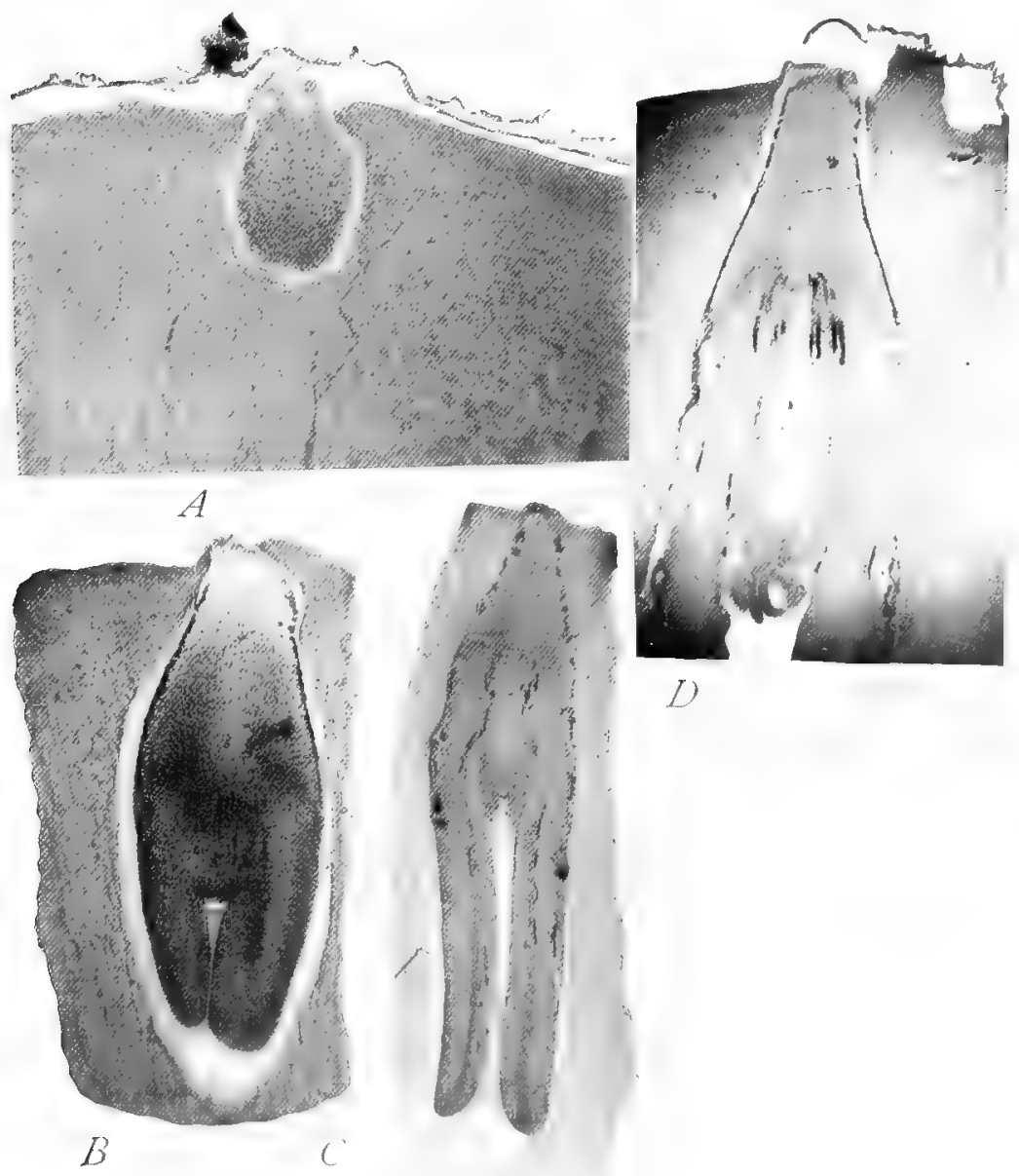

Fig. 35.-Photographs of embryos of Ginkgo biloba in various stages: A, young embryo; $B$, older stnge, showing cotyluduus; $C$, a still older embryo, showing several young leaves; $D$, a portion of a nearly nuture enbryo, with conspicuous resin duets in stem, cotyledons, and leaves; the buakliko process supporting the remains of the nucellus is still visible. 
are not sufficiently known. We have been able to secure almost a complete series showing the general outlines of the development (Figs. 34-36), which merely confirms the facts already published. Germination of the oospore begins, as is usual, among Gymnosperms, with repeated nuclear division (Fig. $34, D)$. These nuclei, however, instead of organizing a parietal tissue as in the Cycads, or a basal group as in the Conifers, proceed to fill the whole cavity of the enlarging oospore with free nuclei, which is followed by the organization of a compact tissue (Fig. 34, $E$ ). In a certain sense this structure would seem to represent the proembryo of $\mathrm{Cy}$ cads, but it really represents the whole product of the oospore, in which proembryo, suspensor, and embryo proper are not differentiated. The complete filling of the spore with tissue, and the lack of early differentiation into the great embryonic regions, would suggest a habit more primitive than in either Cycads or Conifers. At the same time, it may be merely a derived character. In any event, the tissue near the base of the spore, which in the other groups develops both suspensor and embryo, shows far greater vigor than the remaining tissue. In the organization of the em-

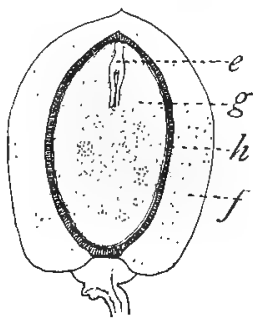

Fis. 36.-Ginkgo biloba, a seed with embryo in stage shown in Fig. $35, C: e$, embryo; $g$; endosperm; $h$ and $f$, hard and fleshy layers of the testa; natural size. bryo the whole mass of tissue is involved, and in the absence of a suspensor the embryo invades the endosperm by direct growth.

The two cotyledons are differentiated early in October, and are quite unequal in length. The larger one is two-lobed, while the shorter one is cleft halfway down, thus early indicating the bilobed character of the leaf. The two cotyledons are also united at the apex, but the epidermal layers of the two are distinct where they are in contact. The plumule is very conspicuous between the elongated cotyledons, three or more leaves appearing just behind the stem apex (Fig. 35).

As in the Cycads, the seed becomes plumlike, a testa with fleshy outer and stony inner layers being organized (Fig. 36). Even without pollination the seed attains its usual size and the two layers of the testa are developed. 


\section{LITERATURE CITED}

1. VAN Tieghem, Ph. Anatomie comparée de la fleur femelle et du fruit des Cycadées, des Coniféres, et des Gnétacées. Ann. Sci. Nat. V. 10: 269-304. pls. 13-16, 1869.

2. VAN TIEGHEM, PH. Recherches sur la symétrie de structure des plantes vasculaires. Ann. Sci. Nat. V. 13: 1-314. pls. 8-8. 1870.

3. STRAsbUrGer, E. Dié Coniferen und die Gnetaceen. 1872.

4. EichleR, A. W. Sind die Coniferen gymnosperm oder nicht? Flora 56: 241-247, 260-272. 1873.

5. Strasburger, E. Die Angiospermen und die Gymnospermen. 1879.

6. Fankhauser, J. Entwickelung des Stengels und Blattes von Ginkgo. Bern, 1882.

7. Eichler, A. W. Coniferae in Engler and Prantl's Die nat. Pflanz. 2': 108. 1889.

8. Čelakorský, L. Die Gymnoospermen Abh. k. böhm. Gesell. wiss. VII. 4: 1 seq. 1890.

9. PAX, F. Allgemeine Morphologie der Pflanzen mit besonderer Berücksichtigung der Blüthenmorphologie. 1890.

10. Strasburger, E. Ueber das Verhalten des Pollens und die Befruchtungsvorgänge bei den Gymnospermen. 1892.

11. Hirasí, S. Études sur la fécondation et l'embryogénie du Ginkgo biloba. Jour. Coll. Sci. Imp. Univ. Tokyo 8: 307-322. pls. 31-32. 1895.

12. FUJII, K. On the Different Views hitherto proposed regarding the Morphology of the Flowers of Ginkgo biloba. Bot. Mag. Tokyo 10: 15-25, 104-110. pl. 1. 1896.

13. Hrrasé, S. E.tudes sur la fécondation et l'embryogénie du Ginkgo biloba. Jour. Coll. Sci. Imp. Univ. Tokyo 12: 103-149. pls. 7-9. 1898.

14. Č́lakovský, L. Die Vermehrung der Sporangien von Ginkgo biloba L. Oesterreich. bot. Zeitsch. 50 : 229-237, 276-283, 337341.1900.

15. FUJII, K. On the Morphology of the Spermatozoid of Ginkgo biloba. Bot. Mag. Tokyo 14: 260-266. pl. \%. 1900.

16. Seward, A. C., and Gowan, Miss J. The Maiden Hair Tree (Ginkgo biloba L.). Ann. Bot. 14: 109-154. pls. 8-10. 1900. 


\section{CHAPTER III}

\section{CONIFERALES}

Trre representative Gymnosperms, at least of the present time, are Conifers. They include about three hundred recognized living species, distributed among thirty-four genera, and constitute fully three fourths of the present Gymnosperm flora. They are characteristic of the temperate regions of both northern and southern hemispheres, presenting a sharp contrast in this regard to the Cycads.

\section{THE VEGETATIVE ORGANS}

THE STEM

The most conspicuous morphological feature of the stem is its regular monopodial branching. The terminal bud continues to be more vigorous than the lateral ones, both in the main axis and in the branches, and as a result the characteristic symmetrically conical form of the Conifers is developed (Figs. 37-40).

The branches are distinctly dimorphic, the two forms being characterized as long shoots and spur shoots. In what may be regarded as the more primitive forms of the stem body both kinds of shoots bear foliage leaves; but in Pinus the main axes bear only scale leaves, while the spur shoots bear the only foliage leares; in Sciadopitys and Phyllocladus the same condition obtains, except that in the former the spur shoot is apparently replaced by the peculiar double needle leaf (Fig. 41), and in the latter it is transformed into the phylloclad.

An interesting fact in connection with these shoots is that in the seedlings a very different behavior of the shoots may be observed. These "juvenile" and usually very transient forms may be "fixed" by artificial culture, so that the plant assumes 


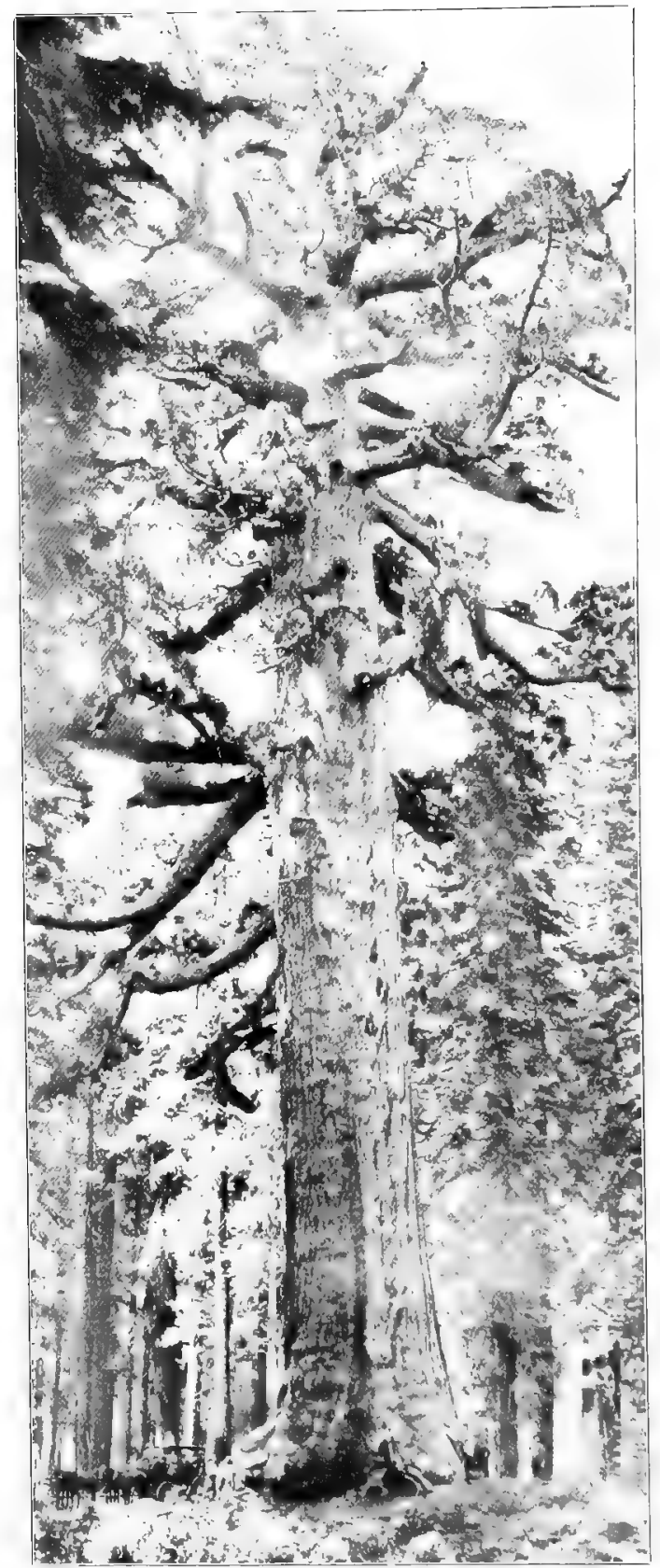

Fia. 37.-Sequoia gigantea. This tree is ten meters in diameter.

From a photograph in possession of the Uuited states Greological survey. 


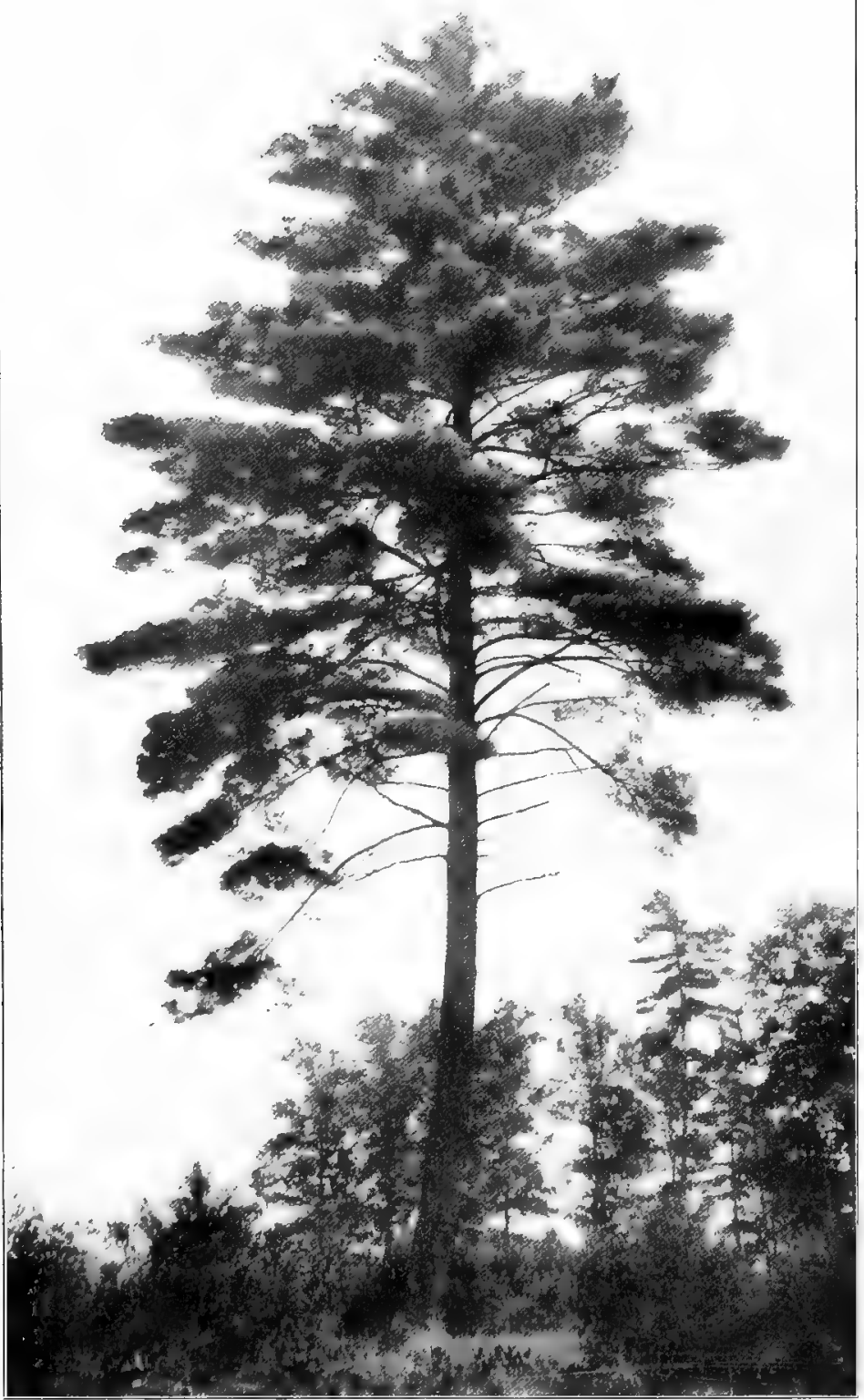

F1t. 38. - Pinus Strobus.-After Forest Tree Photo-reproduction Company of Chicago. 


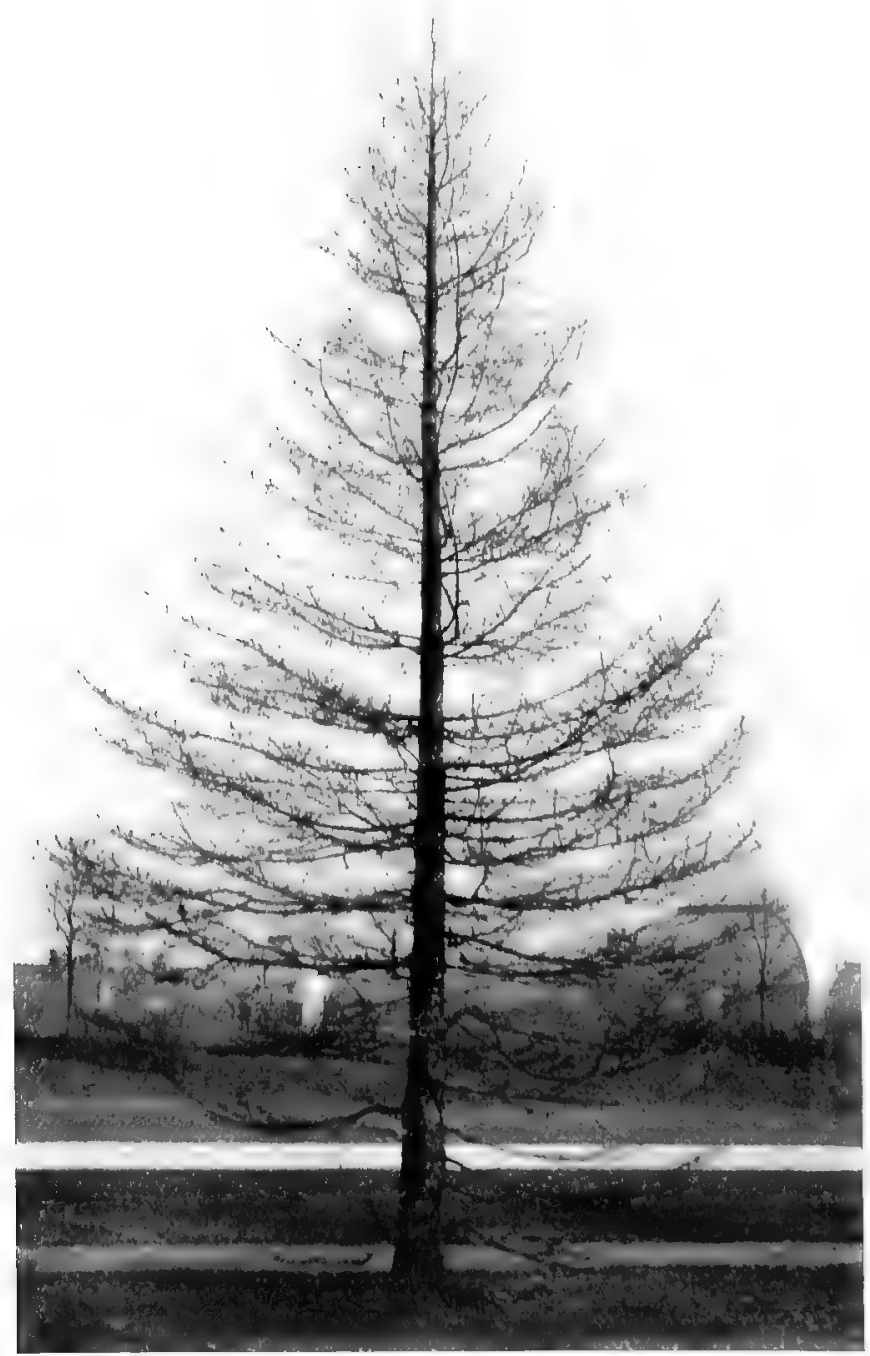

F1a. 39.-Larix sp., after shwhling its lenves,-After Coutter.

a somewhat permanent appearance very different from its normal arlult form. Goebel 40 has recently given an interesting résumé of this subject. For cxample, in Pinus the long shoots 
of seedlings bear foliage leaves, which may disappear from the long shoots in the second year, as in $P$. silvestris, or may continue for many years. These needlelike primary leaves are of simpler anatomical structure than the subsequent foliage leaves, especially in the matter of provision for controlling transpiration. In the juvenile forms of Larix the leaves persist during the winter. It is among the Cupresseae, however, that the greatest amount of work has been done in "fixing" juvenile forms, such relatively permanent forms being known in gardens as species of Retinospora. While some of the adult forms of Cupresseae, as Juniperus communis, retain the more primitive habit of spreading needles, others (Juniperus Virginiana, species of Cupressus, of Callitris, of Chamaecyparis, of Thuja) develop "concrescent" leaves upon their adult shoots - that is, leaves whose upper sides have become organically connected with the adjacent stem surface, so that they appear as green seales. In such eases, the juvenile form, with its spreading needle leaves, presents a striking contrast with the adult form (Fig. 42, $4 D$ ). In Phyllocladus the pliyllo-

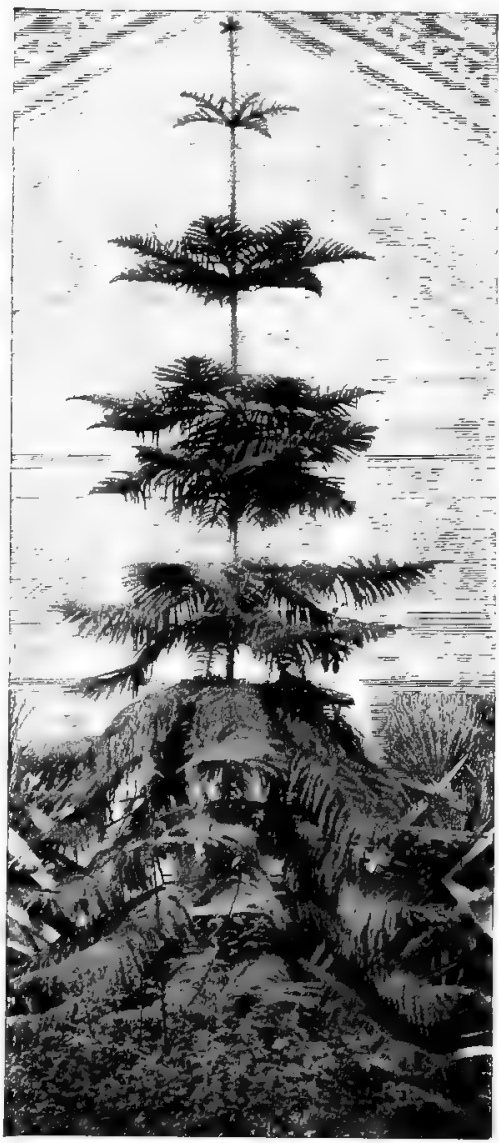

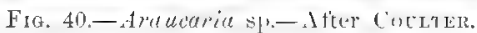
clads are in the axils of small scalelike leaves which are at first green, but later become true scales, and are really the transformed primordia of foliage leaves; while in the juvenile forms the first leares are flat green needles, which are gradually replaced liy shorter and shorter ones until the adult form is reached, and the 
phylloclads themselves only gradually acquire their peculiar character (Fig. $42, E, F^{\prime}$ ). The juvenile forms of Sciadopitys, like those of Pinus, show simple needle leaves upon long shoots, but later scales occur instead of needles, and in their axils the peculiar double needle leaves are developed.

Goebel suggests that the juvenile forms probably represent the more primitive form. These facts in connection with the

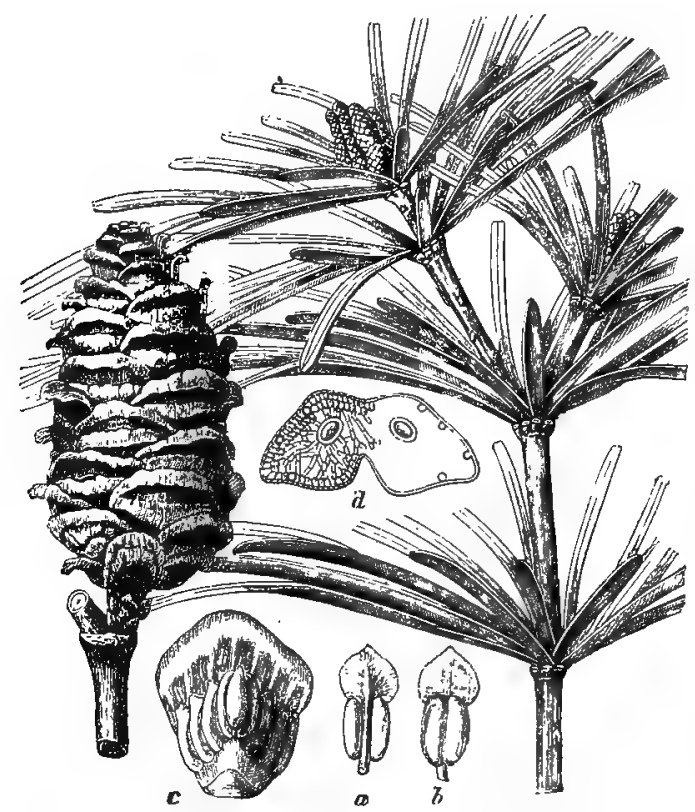

Fro. 41.-Sciadopitys verticillata: at the left an ovulate strobilus, at the right a branch with staminate strobili, one third natural size (from Gardener's Chronicle); $a$, ventral view, and $b$, dorsal view of staminate sporophyll; $c$, ovulate sporophyll; $d$, cross section of the double leaf: $a, b, c$, after Sieb. and Zucc.-Whole figure from ENGLer and Prantr's Nat. Pflanzenfam.

group furnish an admirable illustration of what the zoologists have styled the "recapitulation theory," which has been tersely defined as meaning that ontogeny repeats phylogeny. It is certainly true that if the adult bodies of many of the forms not mentioned above be associated with these juvenile forms, a very consistent shoot body is discovered for Conifers. It would follow that the replacement of foliage leaves by scales on the long shoots of Pinus, Sciadopitys, and Phyllocladus; the pecul- 


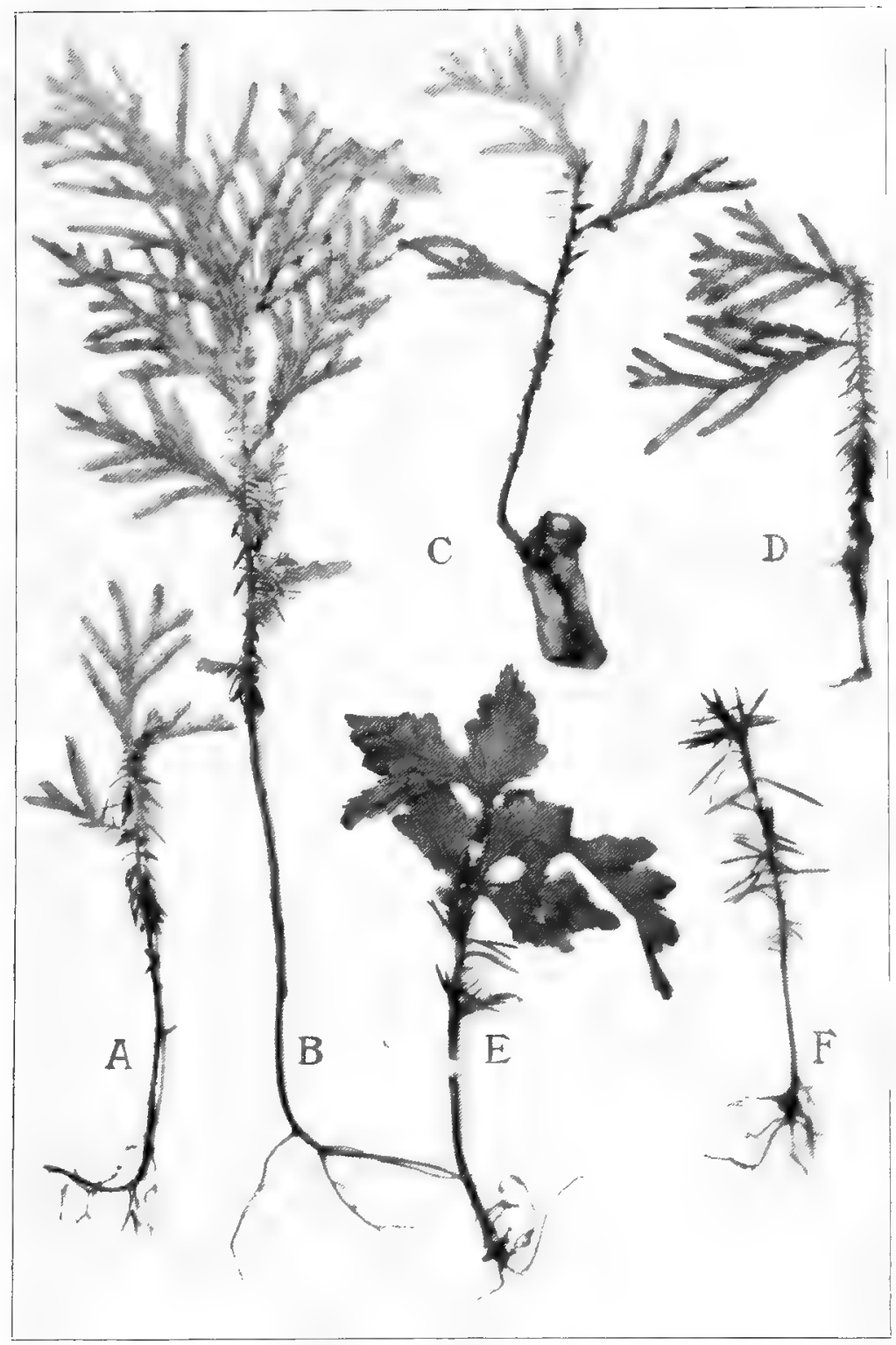

FIG. 42.-Juvenile forms: $A-D$, Thuja occidentalis; $A$ and $B$, seedlings; $C$ and $D$, shoots from adventitious buds; $E$ and $F$, seedlings of Phyllocladus rhomboidalis. 
iar double leaf of Sciadopitys and phylloclad of Phyllocladus; the deciduous habit of Larix; the concrescent leaves of many Cupresseae, are all derived characters, from forms with spreading and persistent needle leaves on all the shoots.

The histological features of the adult stem are quite uniform, and in some particulars peculiar to the group. As was stated under the Cycads, however, the apex of the stem is variable in character. According to De Bary ${ }^{27}$ (page 14), the dermatogen, periblem, and plerome either merge in a common group of initials, as in the Abieteae, or these regions are distinct at the apex, each with its own initials, as in certain species of Araucaria, Dammara, and Cunninghamia. One of the most striking features of the stem, in contrast with that of Cycads, is the persistence of the primary cambium cylinder, resulting in annual increase of diameter through the accumulation of secondary xylem, a character which constitutes the chief resemblance of Conifers to Dicotyledons. The primary bundles contain true tracheary tissue, but with the appearance of the secondary xylem the resemblance to Dicotyledons vanishes, as it consists exclusively of radially arranged tracheids with bordered pits, and is penetrated by narrow and vertically short pith rays. In Pinus, Picea, Larix, Pseudotsuga, and probably other genera, the pith rays are of two general types, either very narrow, often but one cell broad, or lenticular in tangential section, with a resin duct in the middle. In vertical extent the number of cells is quite variable, probably three to sixteen representing the average range of numbers. De Bary ${ }^{27}$ (page 490), reports one to twelve as the number of cells in the vertical plane of the pith rays of some Abieteae; while in Cedrus and in certain fossil forms the number may rise as high as fifty. The bordered pits are usually developed only upon the tracheid walls toward the pith rays, and are discovered, therefore, by radial longitudinal sections (Fig. 43). The cells of the pith rays also have large closed pits upon the walls adjacent to the tracheids. 1 ll of the bundles are common, a single strand connecting with each leaf, none of them being cauline as in Cycads. Companion cclls are also lacking, as in Pteridophytes. The open collateral bundles have retained no trace of a concentric origin, as in the Croads, unless the peculiar bundles found hy Worsdell ${ }^{48}$ in the cotyledons and fleshy seed integument of Cephalotaxus may be re- 
garded as giving evidence of such a derivation. In other particulars, also, Cephalotaxus seems to be the most cycadlike of the Conifers.

Resin ducts seem to be present in all Conifers except Taxus, always occurring in the leaves and in the cortex of the stem. In

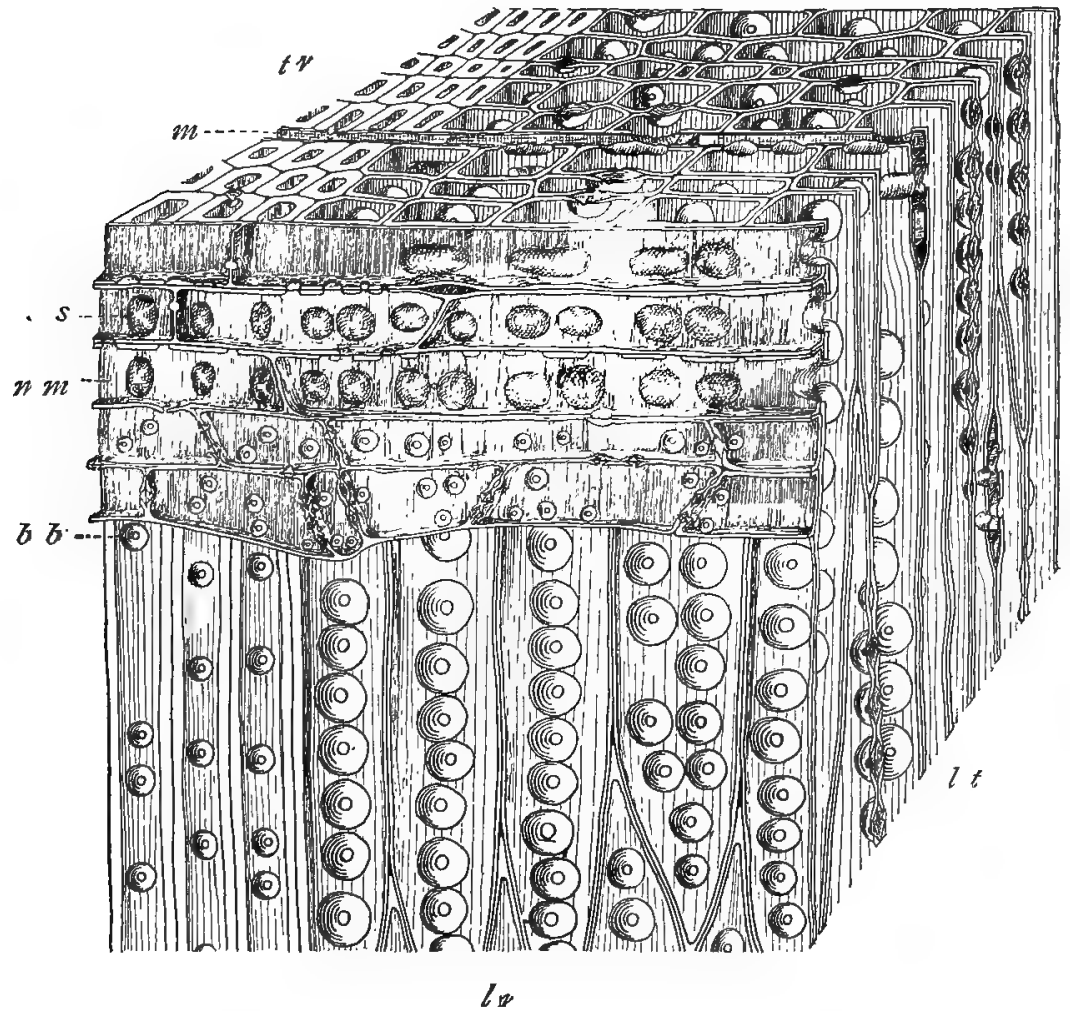

Fit. 43.-A cube from the secondary wood of Pinus Laricio, reconstructed from three camera drawings : in cross section at the left a few rows of small thick-walled cells of the autumn wood are shown, and at the right the larger thinner-walled cells of the spring wood; $t r$, transverse section; $l r$, longitudinal radial section; $l t$, longitudinal tangential section; $m$, medullary ray; $b$, bordered pit ; s, simple pit; $\times 400$.

different genera they occur also in all other regions; for example, in the primary and secondary xylem, and certain pith rays of Pinus; in the primary and secondary phloem of both stem and root in Araucaria, etc. They are absent from the root in many genera, and when present never occur in the cortex. These 
ducts are schizogenous in origin, a group of glandular cells being formed by repeated division, which separate by the splitting of common walls, and organize a passageway which they line, and into which they pour their characteristic secretion.

The chief histological features of the Conifer stem may be summarized as follows: (1) growth in diameter by means of the primary cambium cylinder, (2) secondary xylem radially arranged and composed entirely of tracheids with bordered pits, (3) presence of resin ducts, and (4) absence of companion cells.

\section{THE LEAF}

The occurrence of foliage leaves and scales is far from uniform, as was indicated in the discussion of the stem, and may be outlined in a general way as follows: (1) foliage leaves only, as in most Cupresseae and in Araucarieae; (2) scale leaves only, as in Phyllocladus (the spur shoots being transformed into phylloclads); (3) both foliage leaves and scales, either on the
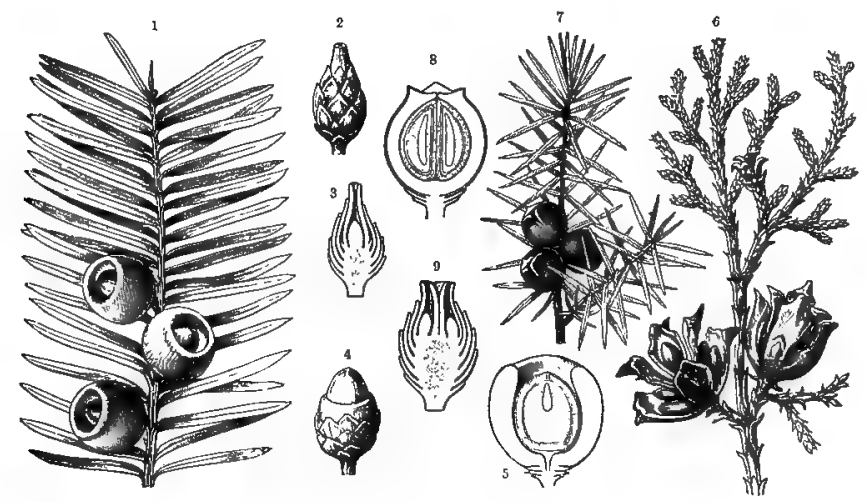

Fra. 44.-Taxus baccata: 1 , branch with ripe seeds; 2 , ovule projecting beyoud scales of the small fertile branch; 3 , longitudinal section of 2 ; 4 , young seed not yet inclosed by aril ; 5, longitudinal section of ripe seed ; 6 , Thuja orientalis ; $7-9$, Juniperus communis.-After KERNER.

same shoot, as in Abies and its allies, or on different shoots, as in Pinus. It was noted in connection with the stem that spreading needle leaves on all the shoots is probably the primitive Conifer condition, and that the scales and other leaf forms have been derived from them.

The foliage leaves are quite variable in form, from small 
discoid ones closely imbricated and appressed upon the axis ("concrescent"), as in many of the Cupresseae, to the characteristic free needles of the Abieteae, and the broad blades of certain Podocarpeae (Figs. 44-46, 53). In general the phyllotaxy is spiral, but in the Cupresseae it is cyclic. The foliage

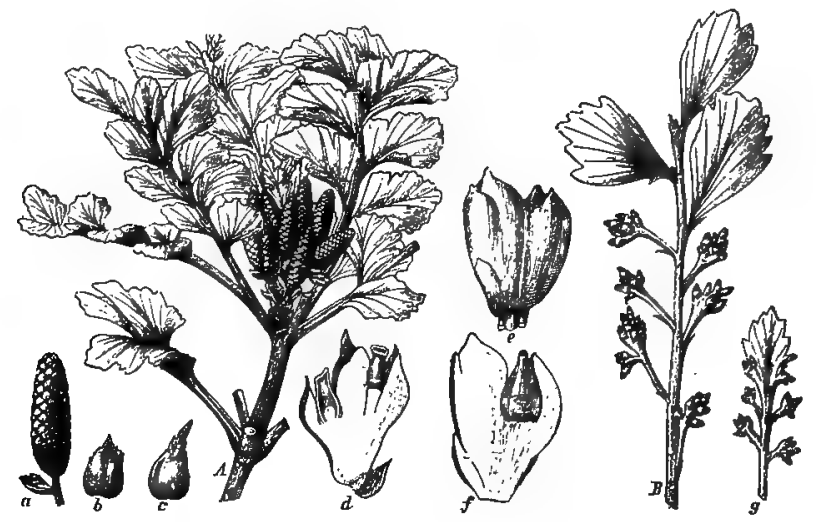

Fig. 45.-Phyllocladus spp.: $A$, branch with staminate strobili ; $a$, staminate strobilus; $b$ and $c$, sporophylls from $a ; d$, longitudinal section of ovulate strobilus ; $e$, mature ovulate strobilus; $f$, Jongitudinal section of $e ; B$ and $g$, ovulate branches. $A$ and $a-d, P$. trichomanoides, after Hooker; $e$ and $f, P$. rhomboidalis, after RroHARD; $B$ and $g, P$. glauca.-Entire plate from Engler and Prantl's Nat. Pflanzenfam.

leaves are very persistent, enduring from one to ten years, the basal growth permitting them to increase in size at base with the increase in the diameter of the axis. So far as recorded, the only Conifers with deciduous leaves are Larix, Taxodium distichum, and Glyptostrobus, a habit which seems to be a derived one, as in the juvenile forms of Larix the leaves persist through the winter.

The histology of the foliage leaf reveals a very xerophytic structure, and argues for adaptation to extreme conditions. The epidermis consists of elongated, fiberlike cells, with strongly cutinized walls, the guard cells being deeply sunken. The rigidity is chiefly due to the hypodermal layers or masses of elongated sclerenchymatous cells. In case the leaf is flat the mesophyll differentiates into the palisade and spongy regions, but if it is acicular the mesophyll is uniform throughout; in any case there are curious platelilie "infoldings" of the wall. In the acicular leaves there is a single central bundle region, 
invested by a rery distinct bundle sheath, in which two vascular bundles of the ordinary collateral type are developed. The re-

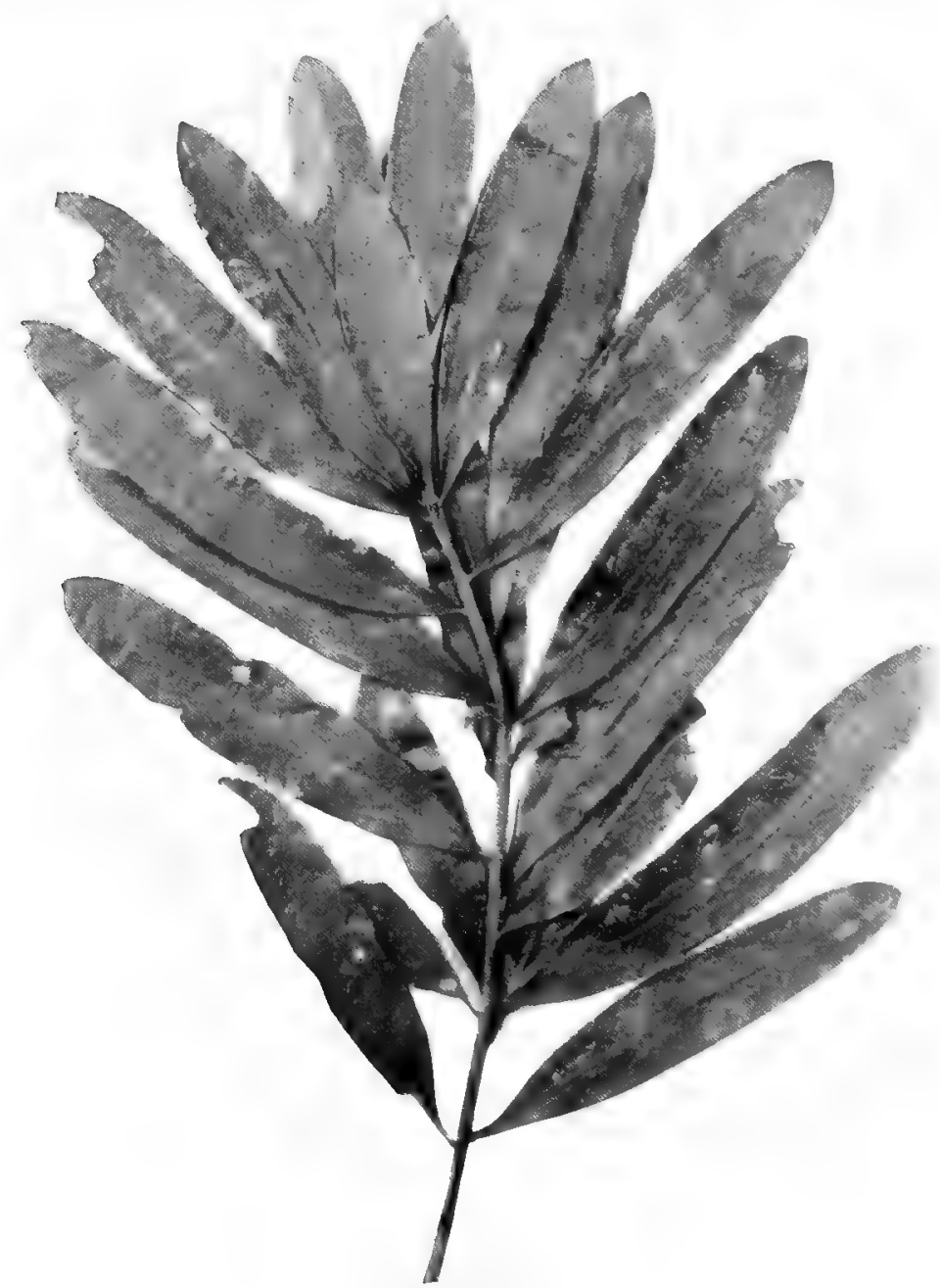

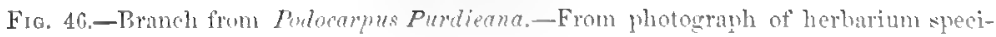
unen, two thinds naturul size.

maining tissue within the sheath is organized as "transfusion tissue," consisting of two kinds of parenchymatous cells, (1) those without protoplasm and pitted, and (2) those with proto- 
plasm and not pitted. 'The former cells are said to represent an extension of the tracheid system, passing water from the xylem to the mesophyll; and the latter to mediate between the mesophyll and the phloem in the transfer of organized material (Fig. 47).

The single bundle which enters the leaf divides into two strands in the narrow leaves, and the strands run parallel and near together with a common bundle sheath. In broader leaves

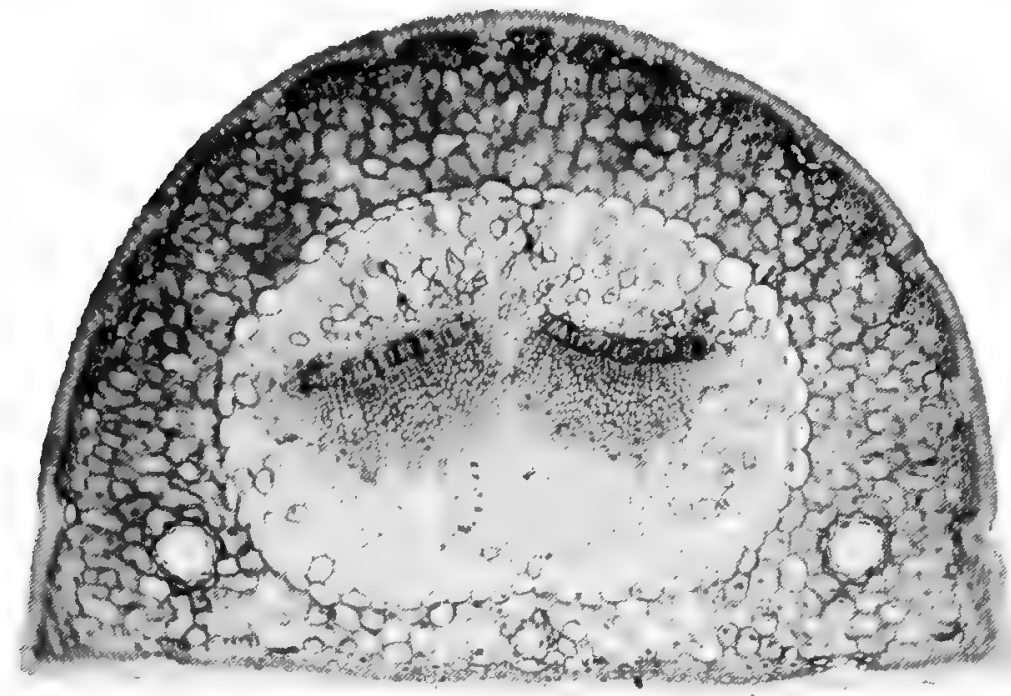

Fis. 47.-Pinus Laricio, eross section of a needle, $\times 70$.

the bundle divides into several more divergent strands. In no case do the veins come near the surface, but run through the middle tissue.

\section{THE ROOT}

In strong contrast with the Pteridophytes, the primary root in Conifers persists as a tap root; while, according to De Bary ${ }^{27}$, following Strasburger, ${ }^{17}$ the differentiation of the meristem at the apex is essentially different from that of Angiosperms, as was indieated in connection with the Cyeads. The description given by De Bary is essentially as follows, and the accompanying figure (Fig. 48) from the same source will fully illustrate it: "A plerome cylinder with sharp 
contour occupies the center. The longitudinal rows of cells which compose this converge at the rounded apex toward a small

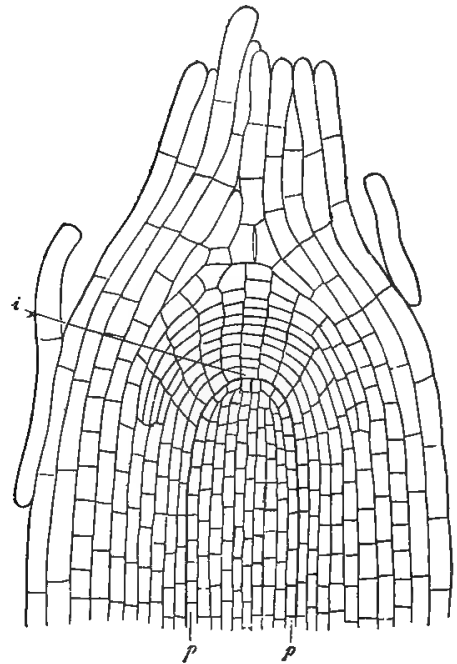

Fig. 48.- Juniperus oxycedrus, longitudinal section of lateral root: $p-p$, plerome, surrounded by about sixteen layers of periblem, the outermost of which represent the root cap; $i$, initial region for periblem and plerome. -After De Bart. initial group of cells. The plerome is surrounded by a mantle of periblem consisting of many (in Thuja occidentalis 12 to 14) concentric layers arranged with considerable regularity. Each one of the inner layers (in Thuja 8 to 10) of this mantle has its initial group above the apex of the plerome." Cell divisions perpendicular and parallel to the surface increase the surface elements of the layer and the number of layers. "As the layers are pushed outward above the apex by their successive doubling, division ceases in them, and increase of volume of the cells takes place; those which happen to be outermost at the apex become gradually loosened, and pushed off as a root cap. Here, then, it is not possible to distinguish a layer of calyptrogen or of dermatogen; the outermost periblem acts as root cap covering the meristematic apex."

The vascular axis is mostly diarch, a simpler structure than in Dicotyledons generally, and much simpler than in Monocotyledons.

\section{THE SPORE-PRODUCING MEMBERS}

THE MICROSPORANGIUM

The strobili of Conifers are always monosporangiate, either monoecious, as in ibieteae and Thuja, or dioecious, as in Araucaria, Juniperus, and Tarus. The microsporangiate strobili are usually much more numerous than the megasporangiate ones, and are never terminal on the primary axis, or even upon 
the larger branches (Figs. 49, 50, 53, 57, 58). Sometimes they appear terminal on small leafy shoots of the last order, and sometimes they occur in the axils of the leaves of stronger shoots. In Pinus they replace spur shoots in the axils of scales, being usually numerous and forming a cluster beyond which the parent axis continues its growth.

The sporophylls follow the leaf arrangement; for example, they are spiral in Abieteae, and cyclic in Cupresseae. They are exceedingly variable in form, nearly every genus having a characteristic microsporophyll (Fig. 51). In almost every case there is an evident differentiation into a stalk like base and an expanded terminal portion, the latter bearing the sporangia. Peltate forms occur, as in Taxus, recalling the sporophylls of some of the Cycads and of Equisetum, and from beneath the peltate expansion the numerous free sporangia are pendent by a narrow

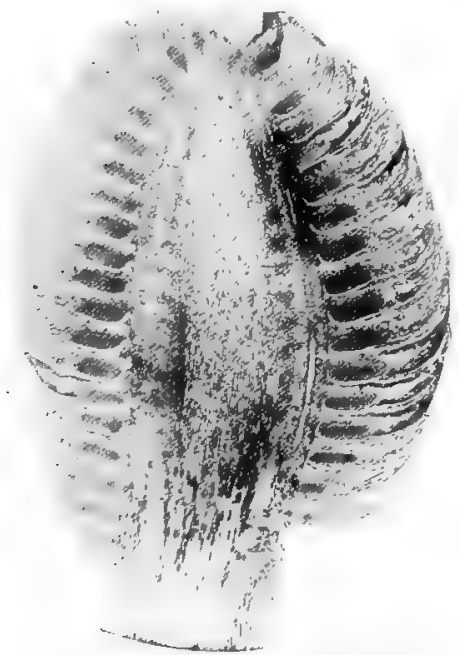

Fis. 49.-Pinus Laricio. Longitudinal section of a staminate strobilus collected in November, $\times 14$.

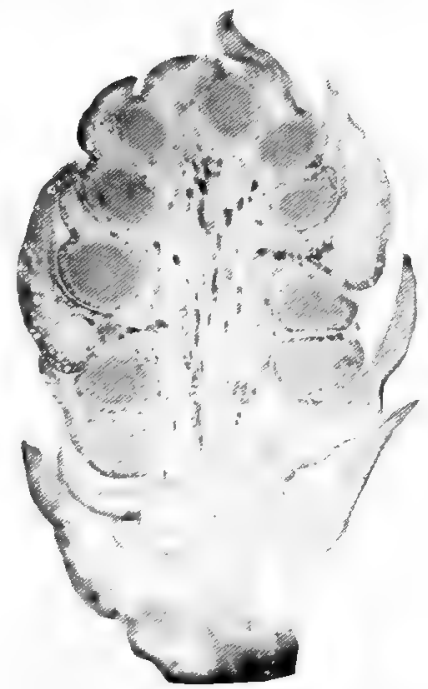

FIQ, 50.-Juniperus communis, longitudinal section of a stiminate strobilus, $\times 24$.

base. Numerous modifications of the peltate type occur, as in Araucaria, Cupressus, Cryplomeria, etc, as well as transitions to the type exhibited by Pinus and its allies, in which the expanded portion continues the plane of the stalk, and bears upon its lower surface two pouchlile nore or less imbedded sporangia. 
A microsporophyll of Pinus bears a certain superficial resemblance to the ordinary stamen of Angiosperms, but the "pollen sac" of the latter is not the morphological equivalent of the microsporangium of the former. In general, the microsporophylls of Conifers bear less numerous sporangia than do those of Cycads, and a much more variable number than do those of Angiosperms.

The sporangia are protected in various ways. Sometimes they are more or less sunken in the tissues of the sporophyll (Pinus, Abies, etc.) ; sometimes they are covered by an outgrowth from the under surface of the bladelike expansion ( $\mathrm{Cu}$ pressus, Thuja, Juniperus, etc.) ; and in many cases they are freely suspended by a narrow base, but protected by the close abutting of the peltate portions.

The sporangium develops in the usual eusporangiate manner, organizing several wall layers and developing numerous mother colls (Fig. 68). We find that in Pinus Laricio the number of wall layers is usually five, the innermost organizing the
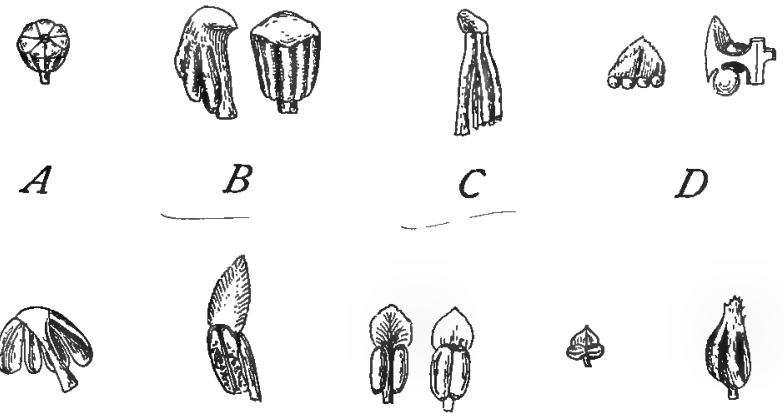

$D$
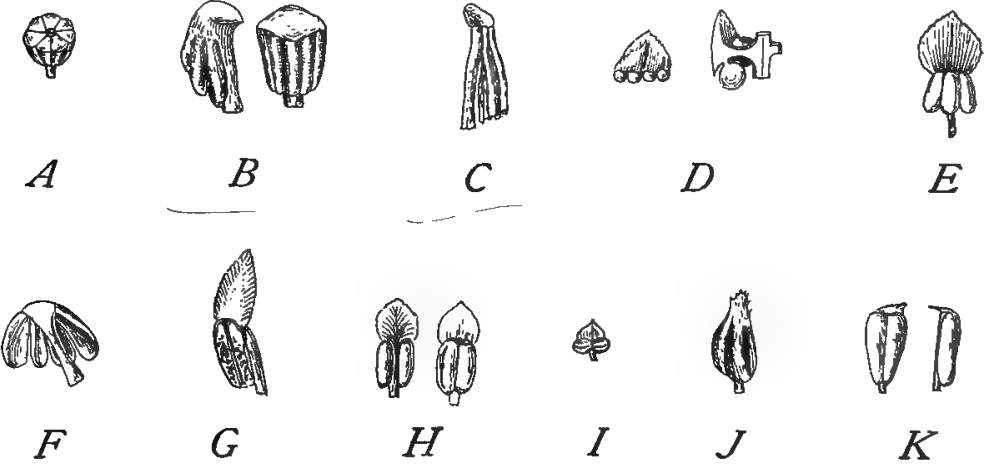

F1G. 51.-Microsporophylls of various Conifers: A, Taxus baccata; B, Agathis Dammara; C, Araucaria Brasiliana; D, Cupressus sempervirens: E, Cunninghamia Sinensis; F, Torreya taxifolia; G, Cedrus Deodara; H, Sciatopitys verticillata; $I$, Dacrydium cupressinum; J, Podocaspus Totara; $K$, Pinus Laricio._.1-.I selected from Enguer and Hran's's Nat. Pflanzenfum.

peripheral section of the tapetal layer, and the next outer one being composed of rery flat tabular cells, which have probably been flattened in the process of supplying nutrition to the adjacent tapetal cells. Chamberlain ${ }^{38}$ has found that the mierosporangia of Pinus Laricio, Cupressus Lawsoniuna, and Taxus bac- 
cata Canadensis are in the mother-cell stage in October, but how much earlier they reach this stage he did not discover (Fig. 52). In this condition the sporangia pass the winter, and during the

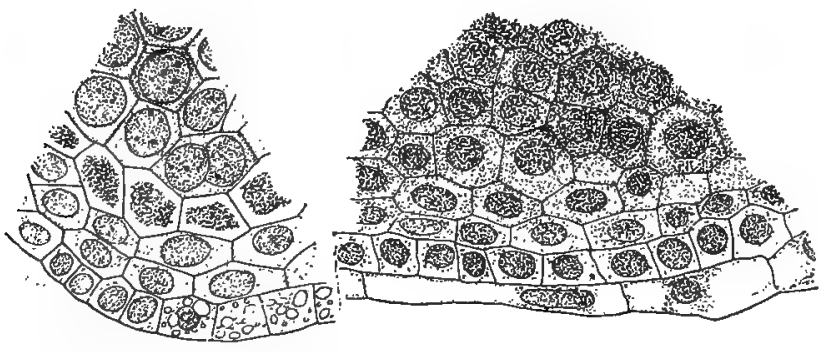

$A$
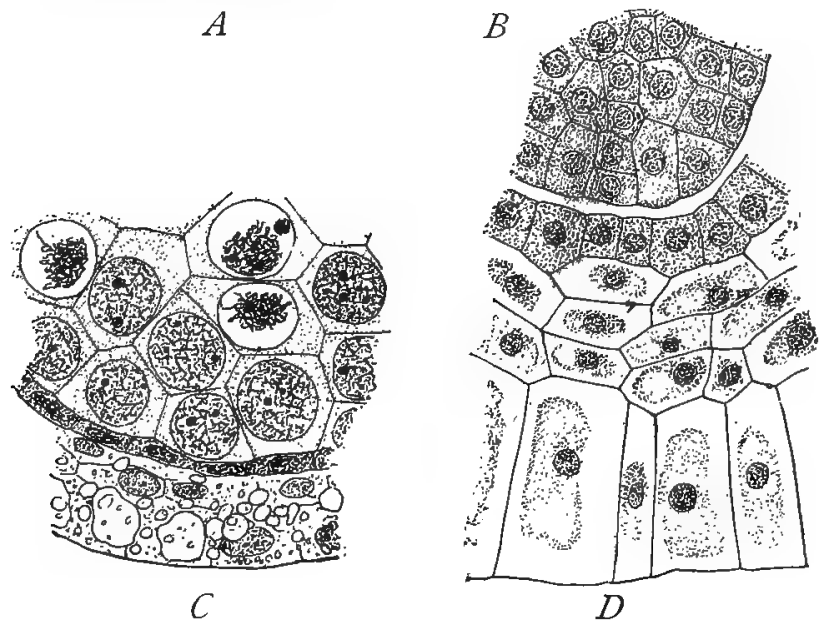

FIG. 52,-Winter condition of microsporangia: $A$, cross section of sporangium of Pinus Laricio, collected October 1st; $B$, same, collected January $3 \mathrm{~d} ; C$, same, collected April 4th; $D$, sporangium of Taxus baccata Canadensis, collected October 1st.-. After Chamberlatis.

following spring (about May 1st in the case of $P$. Laricio) the mother cells pass through the reduction division.

THE MEGASPORANGIOM

The structures associated with the megasporangium in Conifers have long been under discussion, and the literature of the subject is very extensive. There is such great diversity among the various groups that it is difficult to discover any interpreta- 


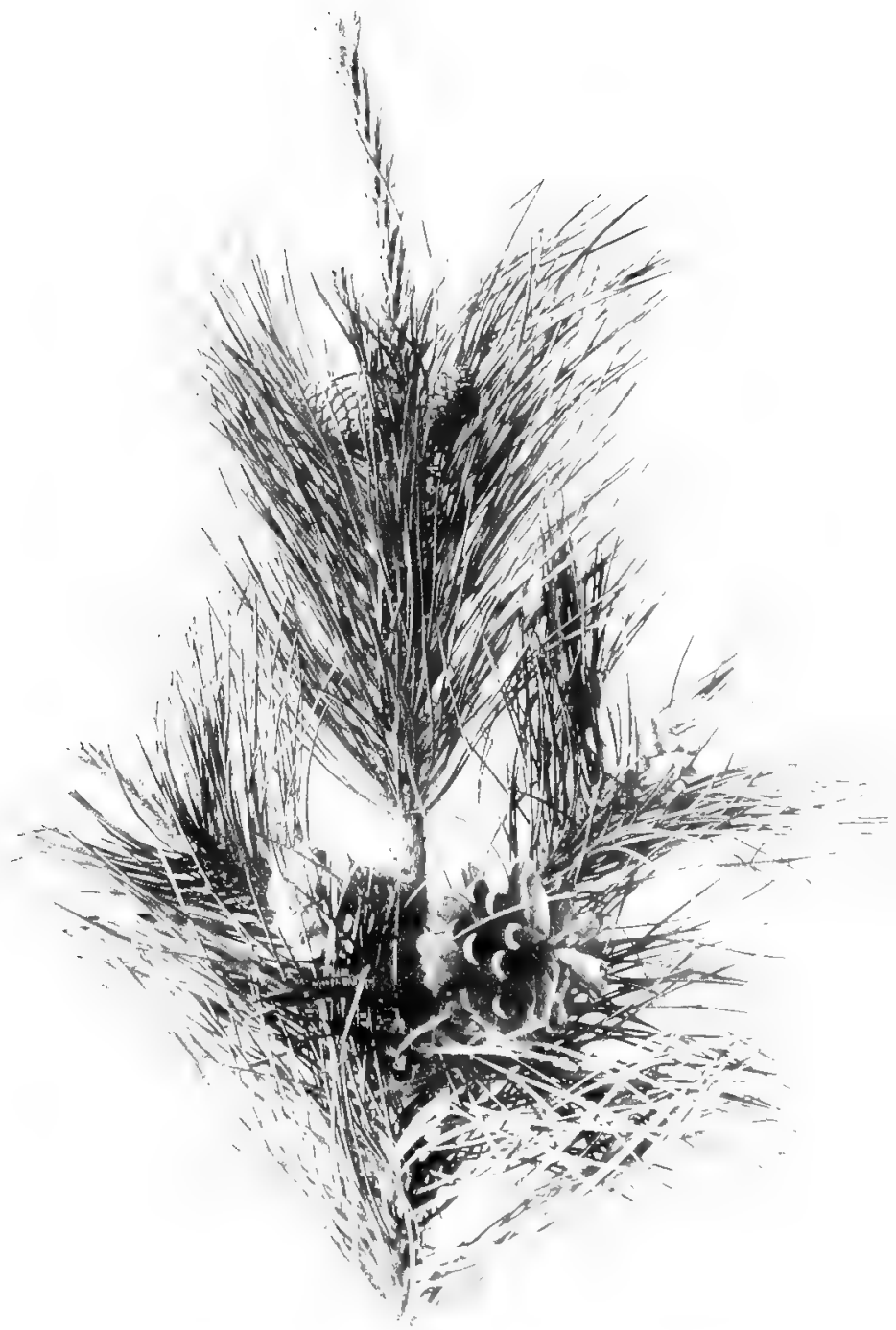

Fuat 53.-Pinus Laricio, branch from the top of a thrifty tree. June 1st; small strobili at extreme top are in stage shown in Fig. 63 ; in the strobili next below, which are a year older, the archegonium initials are distingruishable (Fig. 64); the strobili next below, another year older, havo shed their soeds; to the right is a cluster of ataminate strubili, just rethly to sled their pollen. 
tion of the structures which can find general application, and yet the groups are so evidently related that any explanation of the ovuliferous structures in one group must apply to all. A brief statement of the principal differences is as follows:

In the Abieteae there is a small bract, a very much larger and woody ovuliferous scale coalescent with the bract at the very base, and two inverted basal ovules. In the Araucarieae there is a prominent bract, a ligulelike ovuliferous scale (present in Araucaria, wanting in Agathis), and a single imbedded ovule some distance above the base. In the Taxodieae and Cupresseae there is a single bract or scale structure with two distinct apices at the free and enlarged end and bearing one (Juniperus) to many (Cupressus) ovules; in Juniperus this structure becomes Aleshy in the organization of the "berry." In the Taxeae there is a single ovule at the end (?) of a short secondary leafy axis, being attached to no scale or bract, but becoming inclosed in seed by a colored and fleshy "aril."

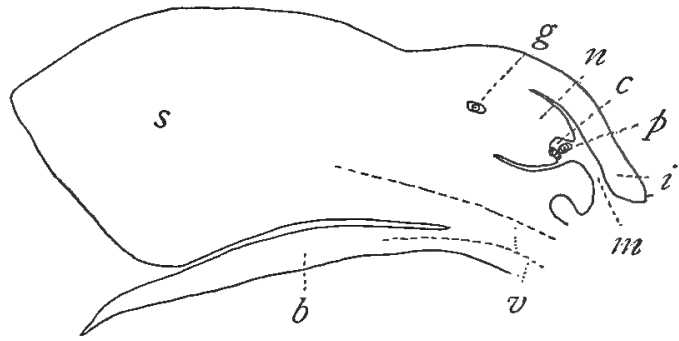

Fra. 54.-Pinus Laricio, diagram of ovule and associated structures: $b$, bract; $\delta$, ovuliferous seale; $v$, vascular bundles; $m$, micropyle; $i$, integument ; $p$, pollen grains; $c$, cavity in apex of nucellus; $n$, nucellus; $g$, embryo sac.

In the Podocarpeae (chiefly Podocarpus) there is an "anatropous" ovule associated with a bract but carried up far above it on a long stalk, and two integuments (the outer becoming fleshy and colored); in some species bracts and axis become fleshy and fuse together "into a colored, succulent whole" (Figs. 44, 45, 53-58).

The chief contention has been in reference to the nature of the ovuliferous (or seminiferous) scale, and in reference to the integument. A very valuable historical study of the subject has been published recently by Worsdell, ${ }^{47}$ who has brought together in compact form the principal views which have been held, and to whom we are indebted for much in the following brief account.

Before 1827, in which year Robert Brown ${ }^{\mathbf{1}}$ announced gym- 
nospermy, the ovuliferous structures were interpreted in terms of Angiosperms, the ovule being regarded as a pistil, and the related parts being variously interpreted. Brown's conclusion as to a naked ovule was derived from a comparison of the so-
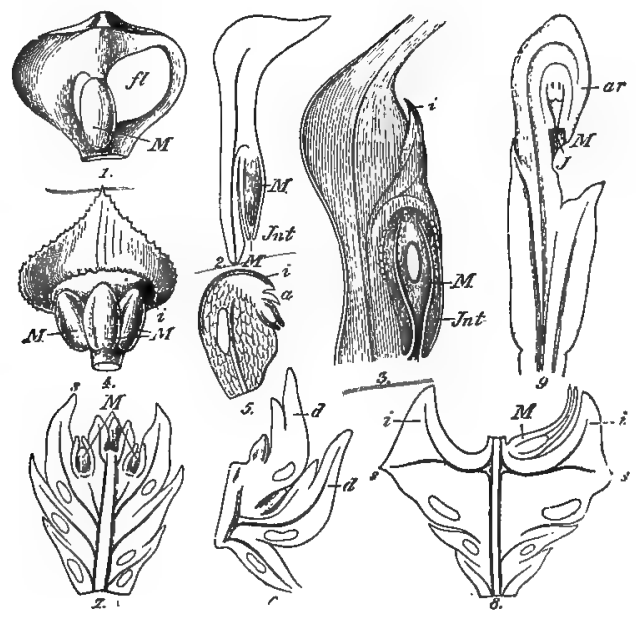

Fig. 55.-Ovulate structures of various Conifers: 1 . Agathis australis, ovuliferous scale from inner side ( $M$, winged seed) : 2 , longitudinal section of $1 ; 3$, Araucaria excelsa, longitudinal section of scale, etc., also showing the outgrowth $(i)$ above the seed; 4. Cunninghamia Sinensis, ovuliferous scale, showing three ovules $(M)$, and an outgrowth (i) ; 5, Microcachrys tetragona, longitudinal section of ovuliferous scale, also showing the arillus (a) and the outgrowth (i); 6, Cryptomeria Japonica, longitudinal section of part of the strobilus; 7 and 8 , Cupressus Lawsoniana, showing a young cone (7) and a later stage $(8) ; 9$, Podocarpus macrophylla, longitudinal section, showing ovulate structures and aril (ar).-From Engler and Prantr's Nut. Pflanzentam.

called "ovule" (nucellus) of Creads and Conifers with the ovule of Angiosperms. His corollary was that the ovuliferous scale represents an open carpel, but his statement that this socalled carpel is a leaf in the axil of a bract called forth strong dissent.

In 1839 Schleiden ${ }^{2}$ called attention to the fact that Brown's "folium in axilla folii" is a morphological impossibility, and that the ovuliferous scale is a flattened axis in the form of a placenta, a view concurred in later by Baillon, Dickson, Strasburger, and Masters, but without regarding the axis as a placenta, the axial nature of placentas in general being one of Schleiden's peculiar views. 
In $1845 \mathrm{Von} \mathrm{Mohl}^{3}$ suggested that the ovuliferous scale is a leaf of an axillary shoot, but later (1871) he modified his view somewhat.

In 1853 A. Braun ${ }^{4}$ first advanced the theory that the ovuliferous scale represents the first two leaves of an axillary shoot, which are fused by their margins, a view held later by Caspary, Parlatore, Oersted, Von Mohl, Stenzel, Engelmann, Willkomm, and Čelakovský. Braun's illustrative material consisted of a monstrous cone of Larix, in which the ovuliferous scale was replaced by a short branch bearing two leaves transversely placed, the bract developing as a foliage leaf.

It may be of interest to note that in 1860 Baillon ${ }^{6}$ announced his opposition to the theory of gymnospermy, a posi-

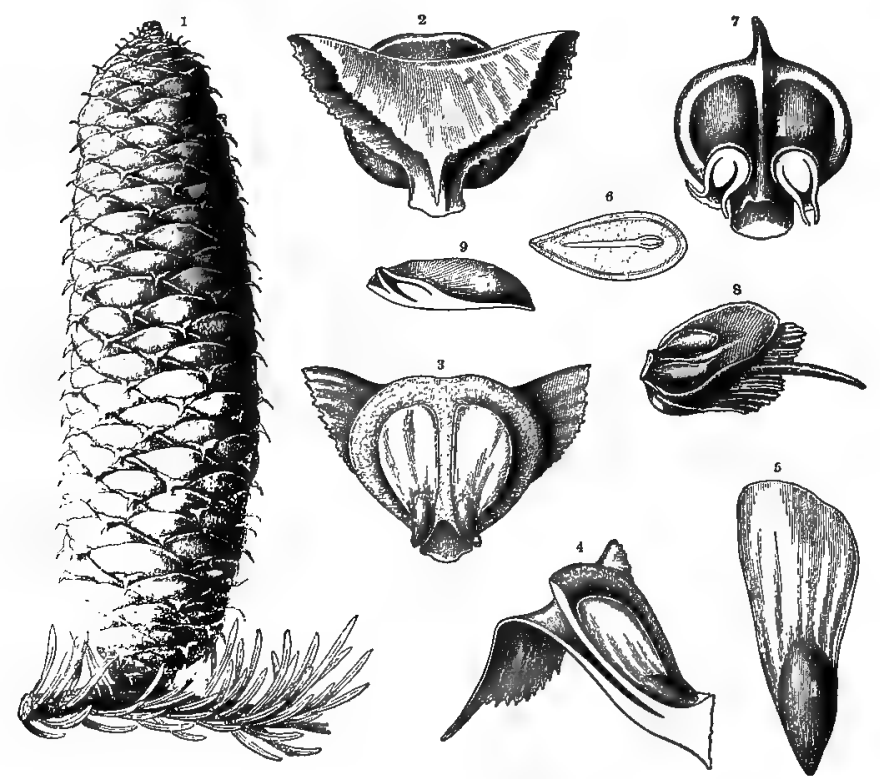

Fig. 56.-Ovulate structures of various Conifers: 1, Abies pectinata, ovulate strobilus; 2 , dorsal view of bract and ovuliferous scale; 3 , rentral view of same; 4 , longitudinal section of same; 5 , a winged seed; 6 , longitudinal section of seed; 7 , Pinus silvestris, ventral view of ovuliferous scale; 8 , Larix Europaea, ovuliferous scale, and bract with bristle; 9 , longitudinal section of same.-After KERNER.

tion which he maintained persistently, basing it upon the first really careful researches in the organogeny of the structures under discussion. He sustained Schleiden's view that the ovu- 
liferous scale is an axis, but regarded it as an axillary shoot rather than a placenta.

In the same year (1860) Dickson ${ }^{8}$ recorded some cones of the Norway spruce (Picea excelsa) in which the lower bracts were replaced by stamens, while the upper bracts bore axillary

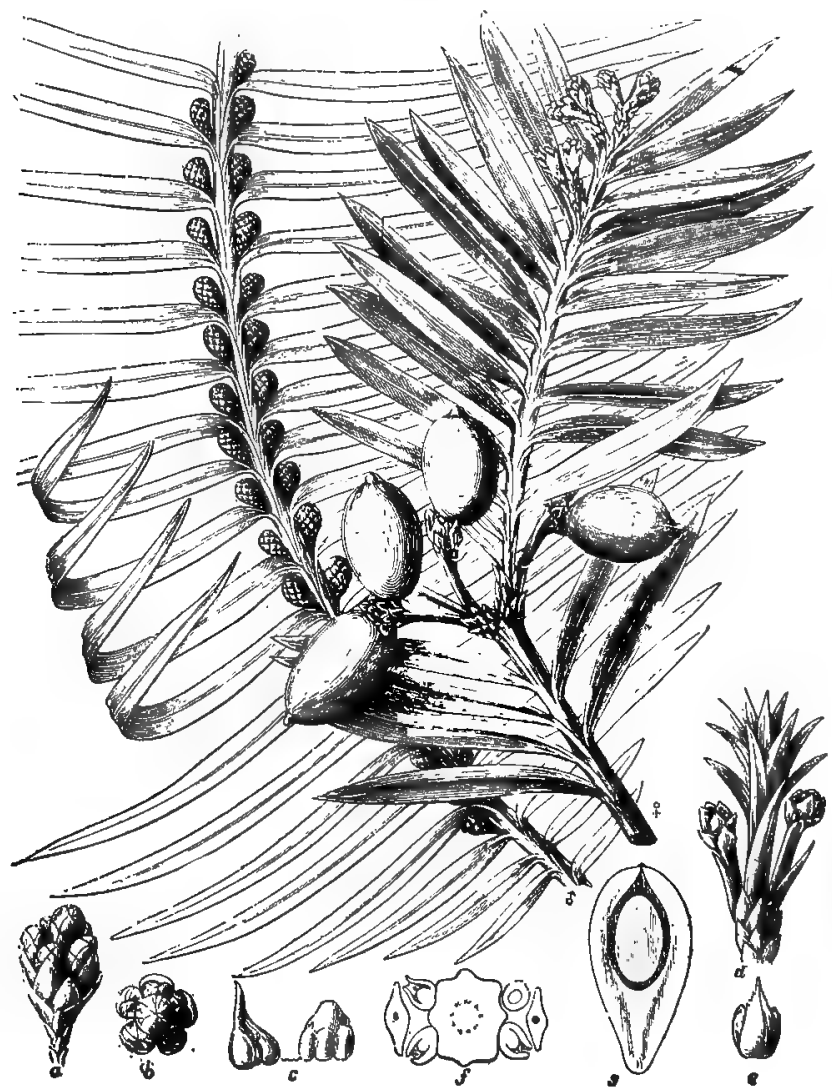

Fig. 57.-Cephalotaxus spp. : staminate branch and details of structure $(a-g)$ of $C$. Fortunei; ovulate branch of c'. pedunoulata.-From Engler and Prante's Nal. Pflanzenfum.

scales as in the normal ovuliferous cone. His position, therefore, was that stamens are to be homologized with the bracts of the ovuliferous cone, and that the ovuliferous scales represent axes of the next higher order, and are "simple flattened shoots," as Schleiden had urged. It may be remarked that 
a similar monstrosity has been reported by $\mathrm{Shaw}^{34}$ in connection with the cones of Sequoia. For some, such illustrations settle the sporophyll character of the bract, which to them therefore becomes the carpel in the ovuliferous cone (Figs. 59, 60).

In 1860 also Caspary ${ }^{7}$ confirmed Braun's conclusion, citing abnormal specimens in which branches occurred in the axils of the bracts, and bearing the two halves of the ovuliferous scale as lateral appendages.

In 1864 Parlatore ${ }^{11}$ recorded a monstrous cone of Pinus Pinaster (P. Lemoniana) in which an ordinary spur shoot with its two needle leaves sprang from the axil of every alternate bract, replacing an ovuliferous scale. His conclusions naturally accorded with those of Braun.

In the same year (1864) Oersted ${ }^{10}$ recorded some remarkable cones, in which the lowest bracts had the form of foliage leaves; in the axils of the next higher ones were several scales

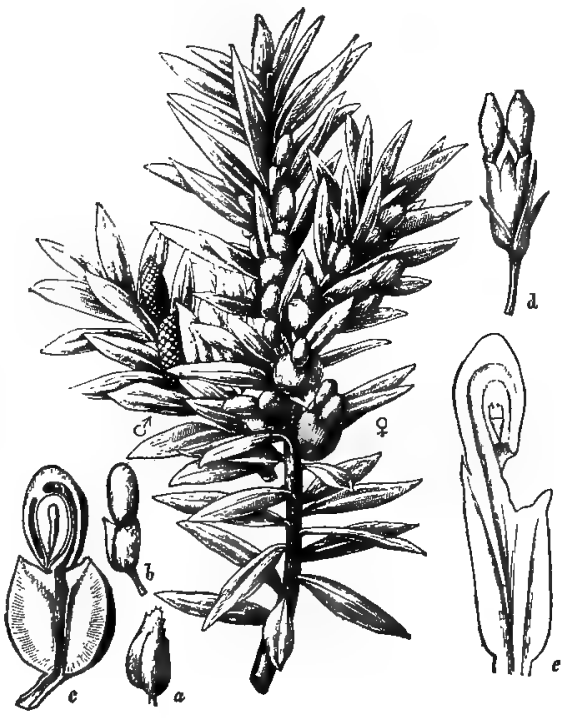

Fig. 58.-Podocarpus spp.: staminate and orulate branches from $P$. Totara; a, microsporophyll; $b$, ovulate structures; $c$, longitudinal section of same; $d$, ovulate structures from P. macrophy $l$ $l a ; e$, longitudinal section of same.-Branches and $a-c$ after HookER; whole plate from $\mathrm{ENG}_{\mathrm{N}-}$ Ler and Prants's Nat. Pflanzenfam.

as on a suppressed axis, the two outermost being largest and opposite; higher up the bracts became gradually smaller and the axillary scales less numerous, but the two outermost scales gradually increased in size and became connate by their posterior margins, while rudimentary ovules appeared at their base; in the uppermost part of the cone the bract was reduced to its ordinary size, and the ovuliferous seales had fused into a single large broad structure dentate or bifid at the apex. His conclusion in general was that of Braun, but in his detailed application he 
regarded the ovnliferous scale in $A$ bieteae as an open carpel, which is lacking in Cupresseae.

One of the simplest explanations of these problematical structures was that proposed by Sachs ${ }^{13}$ in 1868 , and afterward elaborated more fully by Eichler. ${ }^{18}$ They contended that the
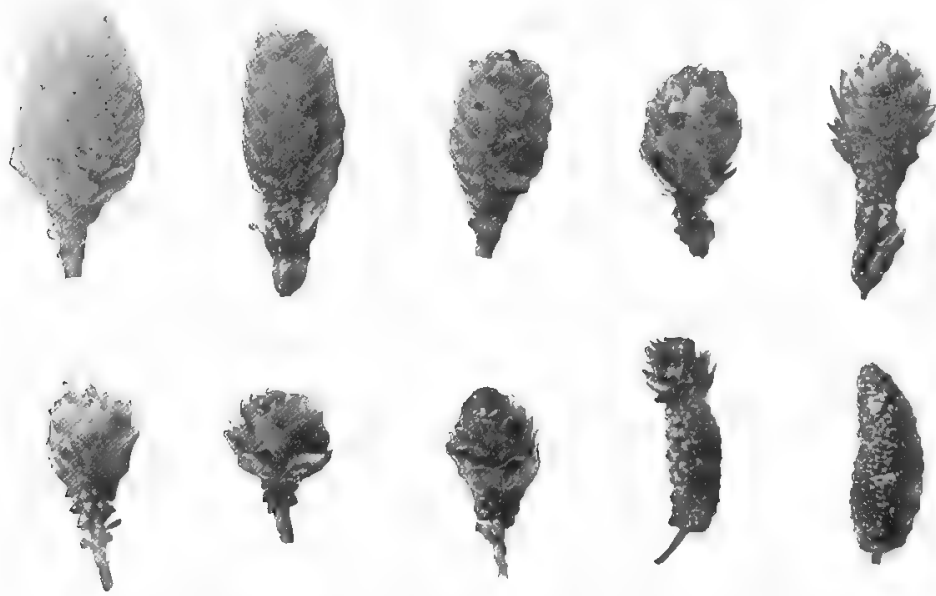

FIQ. 59.-Abnormal strobili of Abies sp.: the staminate cone at lower right-hand corner is alnost normal; all the others have mierosporangia both above and below, with ovuliferous scales between.

bract is a carpel and the ovuliferons scale a ligular outgrowth from it, calling attention to a similar condition of things in the leaves of Isoetes and Selaginella. Such a ligular placenta does not appear in certain groups, as Cupresseae, Taxodieae, and Podocarpeac, and in these cases the bract is evidently an open carpel. The simplicity of this explanation has commended it to writers of text-books, and hence it is perhaps the view which is most current.

In 1869 Van Tieghem ${ }^{14}$ presented his conclusions based upon anatomical structure- a new point of view. He claimed that the ovuliferoms seale is the first and only leaf of an axillary branch, although he suggested the possibility of two fused leares, and bases his statement on the course and orientation of the bundles. IIe states that the bundles of bract and ovuliferous seale leave the main axis each in its own sheath, and thus represent independent systems of bundles; that the uppermost divides and forms an are with inverted orientation, the arrange- 
ment of bundles in the arc showing that the axillary structure is a leaf and not a branch; and that the reversed orientation shows that the leaf belongs upon the suppressed branch opposite the bract. This is not Robert Brown's view of an axillary carpel, but rather Alexander Braun's view that the ovuliferous scale is the leaf of an axillary branch.

In 1871 Von Mohl ${ }^{16}$ further strengthened Braun's position by the publication of his studies of the peculiar "double leaf" of Sciadopitys. He showed that this leaf represents the first two leaves of an axillary shoot, which stand transversely, and which become coalescent by their posterior (toward the axis) edges, the vascular bundles thus showing reversed orientation. As this normal behavior of the leaves of Sciadopitys exactly parallels what was claimed by Braun for the ovuliferous scale, the results of Von Mohl are almost in the nature of a demonstration.

In 1872 Strasburger ${ }^{17}$ announced his adherence to the view that the ovuliferous scale is a flattened axis, at the same time combating the idea of gymnospermy. While later ${ }^{24}$ his views
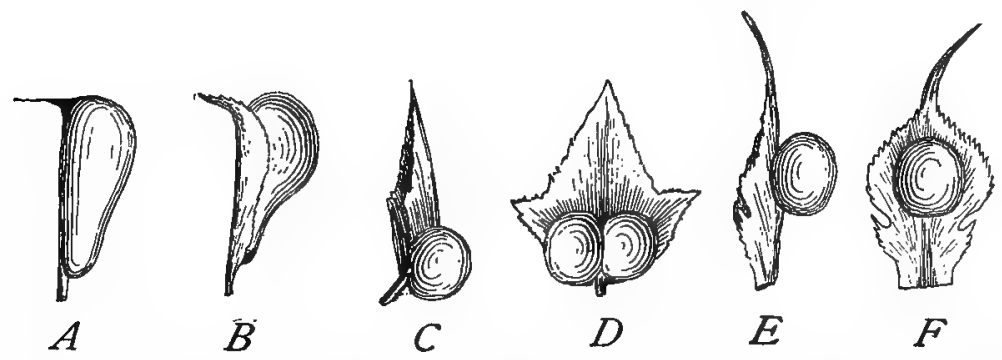

Fro. 60.-Microsporangia from the strobili shown in Fig. 59: $A$, normal sporophyll, side view; $B$, slightly modified sporophyll from summit of a bisporangiate strobilus; $C$ and $D$, side and front views of sporophylls from summit of a bisporangiate strobilus; $E$ and $F$, side and front views of sporophylls from the base of a bisporangiate strobilus.

in reference to gymnospermy became modified, he held to the axial nature of the scale.

In 1876 Stenzel ${ }^{20}$ described striking abnormalities in Picea excelsa. In one cone leafy axes occurred in the axils of the bracts, the first two leaves resembling oviuliferous scales more than ordinary foliage leaves in texture. In other cones the abnormalities recorded by Dickson ${ }^{8}$ were observed. In still 
other cones he found the two parts of the ovuliferous scale in all stages of coalescence. All of his material confirmed Braun's view that the ovuliferous scale is made up of the first two leaves of an axillary shoot, which stand transversely, and are connate by their axial edges. It may be of interest to note in this connection that such a view would refer the megasporangia to the morphologically under surface of the leaf, and in so doing would make them conform with the microsporangia in this respect.

In the same year (1876) Engelmann, ${ }^{19}$ in reviewing Stenzel's paper, reported similar monstrosities in cones of Picea Engelmanni and Tsuga Canadensis.

In 1879 Čelakorský $23,25,29,35$ began publishing upon the subject, and has constructed a theory which seems to unify more nearly than any other the puzzling diversities of structure. In the first place, he regards the ovuliferous scale as the representative of an axillary shoot, confirming in general Braun's view. He states that in this case "Nature takes a short cut," the ovuliferous scale being formed directly, rather than an axis with two distinct lateral leaves. Moreover, he sees in the ovuliferous scale, which has assumed a permanently vegetative character, the modified and blended outer integuments of the two ovules. Therefore, there is present no true carpel in Conifers, this structure being reduced, so to speak, to a single ovule. The microsporophyll corresponds to the bract of the megasporangiate cone, which subtends the axis which bears the hypothetical megasporophyll (represented only by the ovule), the latter being on a shoot of higher order. As a consequence, the axillary ovuliferous structure corresponds to the axillary spur shoot of Ginkgo and the main axis of Cycads. In applying this doctrine of an outer integument in all Conifers, Čelakovský reaches the following conclusions: In the Taxaceae, certainly the older of the two great groups of Conifers, the two normal integuments are evident, being distinct in Taxus, Dacrydium, and Microcachrys (the outer being the "aril"), and represented by the fleshy and bony layers of the seed in Cephalotaxus and Podocarpus, as in Cycads and Gintigo. In Araucaricas, Alicteae, and Cupresseae, the outer integument is the ovuliferous scale (or half of it), being leveloped after the sporangium and showing the inverted orientation, facts true of all outer integuments. In this outer integument he sees the ligule of Isoetes 
and Selaginella, and in the inner integument the indusium of Ferns and velum of Isoetes.

It would seem as though all possible explanations had been suggested. Upon sifting the testimony certain things seem to be fairly clear, and one is that the scale and its ovules in Abieteae represent a highly modified axillary shoot, corresponding to the characteristic spur shoot of the group. In Taxus, representing the more primitive forms, this ovuliferous spur shoot develops normally, bearing a few leaves, and organizing its ovule in a terminal position, but really in the axil of the uppermost leaf, a fact further enphasized by the lateral and axillary ovule of the allied Torreya. In these cases the ovule is distinctly cauline in origin, and holds the same relation to the subtending bract as does the sporangium of Selaginella. Perhaps too much stress has been laid upon the relation of the ovule to the member which produces it. It may be developed from the upper or under surface of the leaf, or from the axis, in the same alliance, but always from periblem tissue. One may expect all of these external expressions of its origin in so ancient and diversified a group as the Conifers, and the desire for absolute uniformity in this regard will probably not be realized. The same spux shoot appears in a somewhat elongated and naked form in Cephalotaxus, while in Podocarpus it is more or less leafy, the uppermost leaf or two bearing an axillary and stalked ovule. Among the Pinaceae the ovuliferous spur shoot reaches its extreme modification, being represented only by its first two leaves, which have fused to form the ovuliferous scale, and this scale may be more or less coalescent with the subtending bract. Whether those leaves of the spur shoot which are intimately associated with ovules, either bearing or subtending them, are to be regarded as carpels or as modified outer integuments is a question we are in no position to answer. It seems simpler to regard them as carpels - that is, leaves modified to bear or subtend ovules, and such a view will be adopted in this book, though not strenuously insisted upon.

Our knowledge of the development of the megasporangium and of the megaspore in Conifers does not permit generalization, and it is impossible to give an account which will include the whole group. One remarkable feature in the forms studied. which may belong to the group in general, is the extreme slow- 
ness with which these structures develop. We have obtained exact information concerning this feature in Pinus Laricio. In the spring, young ovules with distinct integument and nucellus are found, but with no apparent differentiation of sporogenous tissue. It should be remarked that at this season Strasburger 24 found the mother cell differentiated in Larix, and suggested that the ovule had passed the previous winter in this condition. In May the mother cell in Pinus becomes very apparent through great increase in size. It is this stage which is to be
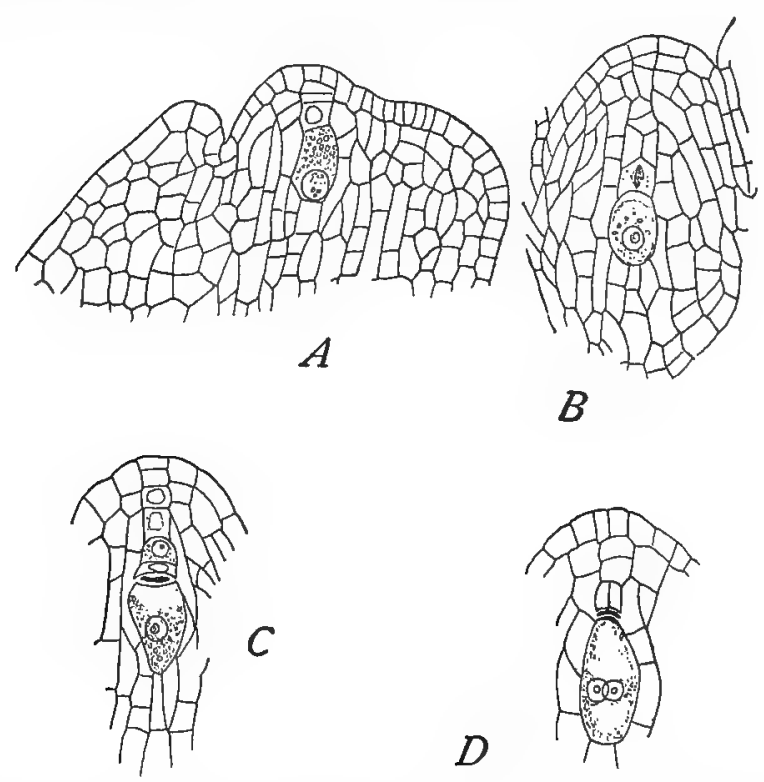

Fra. 61.-Larix Europara: $A$, longitudinal section of a young ovule, showing the megaspore mother cell and tapetal cells, also at the left the beginning of the integument (March 1st) ; $B$, first division of the mother cell ; $C$, the three cells derived from the mother cell; $D$, the beginning of the free nuclear division within the functional megaspore; $\times 150$. -After StraseURGER.

observed in the youngest evident cones, such as appear at the very top of Fig. 53. In the following October the endosperm has begun to develop, and is found as a parietal cytoplasmic layer with few to numerous imbedded nuclei and a central vacuole (Fig. 62), and in this condition the second winter is passed. In the following spring the endosperm begins to develop rapidly, and in June the archegonia are ready for 
fertilization, which occurs about the 1st of July, at least twentyone months after the first organization of the ovule. It should also be renembered that after fertilization the seed is not shed until the following year, fully three years after the first appearance of the ovule. Practically the same history was reported by Strasburger ${ }^{24}$ in the case of Larix, and it probably represents a common condition among Conifers, a condition which is hard to detect without the greatest care.

The portion of this long history which concerns us at present ends with the distinct organization of the mother cell, and it is this very period which seems to have received the least attention. There is current the general statement that the archesporium is differentiated very early as one or more hypodermal cells. While the probabilities are largely in favor of the truth of this statement, we have discovered no complete series of figures to substantiate it except those of Larix given by Strasburger. ${ }^{24}$ In the same connection he gives certian figures of Taxus which indicate the same fact, and also remarks that Thuja, Pinus silvestris, and Pinus $P u-$

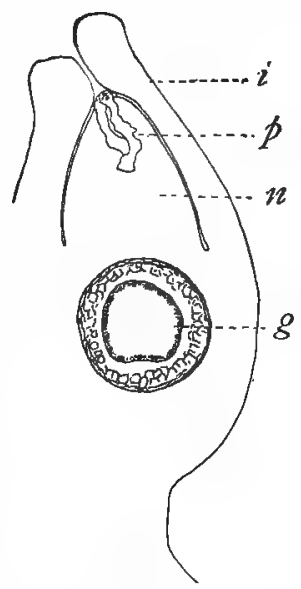

Fis. 62,-Pinus Laricio, condition of megasporangium on May 1st: $i$, integument; $p$, pollen tube ; $n$, nucellus ; $g$, beginning of gametophyte, the embryo suc being surrounded by a definite region of breaking down tissue.

mitio are essentially the same as Larix in this regard. It should be remembered, therefore, that the only close series is from Larix, and that the series is the same in other forms is more or less a matter of inference from fragmentary observations (Fig. 61).

A periclinal wall divides each archesporial cell into an outer primary wall cell and an inner primary sporogenous cell. The wall cells divide repeatedly, and as these divisions are accompanied by division of the overlying epidermal cells an extensive mass of sterile nucellar tissue is developed between the micropyle and the sporogenous cells. Moreover, the divisions are so regular that definite rows of sterile cells extend from the sporogenous tissue to the tip of the nucellus. So far as recorded, the nucellus in Conifers does not develop the persistent beak char- 
acteristic of Cycads and Ginkgo, and the extinct groups; nor is there any distinctly organized pollen chamber, although we have observed in Pinus that the nucellus breaks down at the apex, so that the pollen grains lie in a cuplike depression.

Although the primary sporogenous cells are cut off by the hypodermal layer they are not distinguishable from the neighboring cells until they have become deeply placed in the chalazal

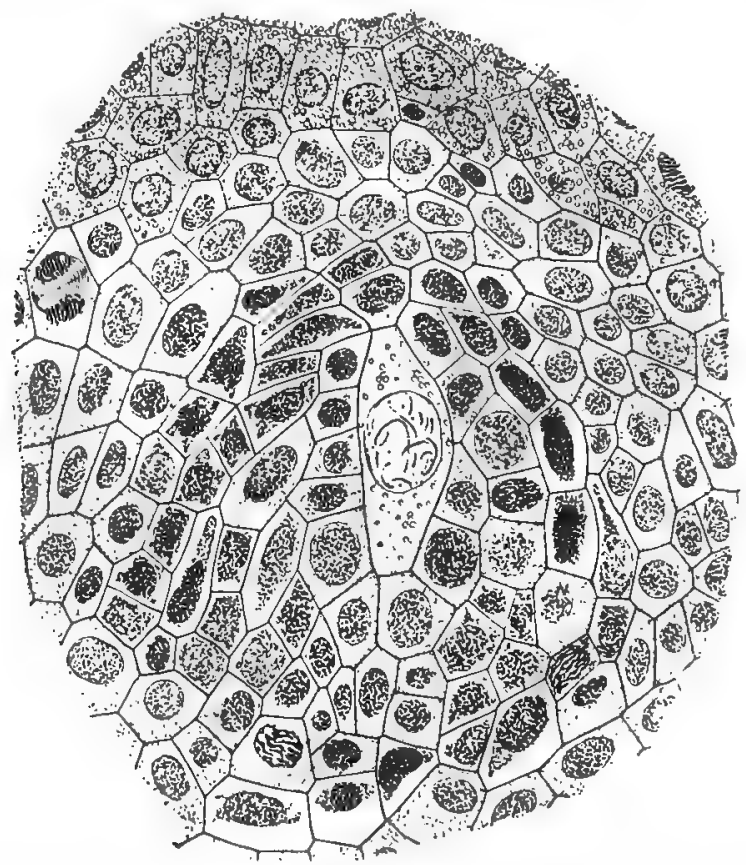

Fig. 63.-Pinus Laricio, longitudinal section of megasporangia June 1st, with megaspore mother cell in the center, surrounded by a region of more or less modified cells ; the nucleus of the mother cell is in the prophase of the reduction division; $\times 500$.

region of the nucellus, and even then there is no differentiation to attract attention until a mother cell begins to enlarge. This tardy differentiation of the sporogenous cells in appearance wis remarked by Strasburger in the case of Ta.rus, and we have found it to be strikingly true in Pinus. Apparently the primary sporogenous cells do not divide, but one or more of them pass over directly into mother cells. Several mother cells have been observed to begin to enlarge in Taxus and in Sequoia, but 
in Larix and Pinus never more than a single one has been observed to become distinct from the neighboring cells.

In our figure of a mother cell of Pinus Laricio imbedded in nucellar tissue (Fig. 63), it is apparent that it is surrounded by a rather definite zone of cells, two to four layers in depth, which give evidence of breaking down. After endosperm formation is somewhat advanced, this investing zone becomes differentiated into two distinct regions, an outer layer of tabular, almost empty cells, and an inner region of polygonal cells with densely staining contents. It is this appearance which has sometimes led to the impression that a definite tapetum surrounds a sporogenous mass. The most usual mistake, however, is to regard the distinct mass of polygonal cells as endosperm cells, overlooking the comparatively inconspicuous embryo sac, a mistake made by Hofmeister ${ }^{9}$ and corrected by Strasburger. ${ }^{24}$

As the mother cell enlarges, its nucellus begins to show signs of the organization which precedes the reduction division and would result in the first appearance of the gametophyte. It may be of interest to note that after the mother cell has begun to enlarge it becomes full of starch, but by the time it has reached the spirem stage for division the starch has disappeared. How far the history outlined above is uniform throughout Conifers must be left to subsequent investigation to determine.

In Sequoia Shaw ${ }^{34}$ has observed an interesting modification. When the growth of sterile tissue at the apex of the nucellus has covered the sporogenous cells with five or six layers, the sterile tissue of the nucellus beneath the sporogenous region begins rapid division and elongation, again placing the sporogenous tissue relatively high in the nucellus.

\section{THE GAMETOPHYTES}

THE FEMALE GAMETOPHYTE

The female gametophyte begins with the reduction division of the megaspore mother cell. In the cases investigated, the mother cells seem to be the primary sporogenous cells, which form a more or less extensive group, and which, although originating from: hypodermal cells, have become deeply placed beneath the extensively developed sterile wall tissue. The deeply placed mother cells (one in Larix and Pinus, usually more in Taxus 
and Sequoia), after considerable increase in size, presumably pass through the reduction division, although this has never been definitely observed. The reduction number of chromosomes was observed by Dixon ${ }^{33}$ in the endosperm cells of Pinus silvestris; while Blackman ${ }^{37}$ and Chamberlain ${ }^{39}$ definitely counted twelve chromosomes in the endosperm of Pinus silvestris and Pinus Laricio respectively. In the case of Larix Strasburger ${ }^{24}$ has demonstrated the existence of a row of three cells derived from the mother cell (Fig. 61), and in Taxus the same number and sometimes more, in both cases the lowest cell becoming the fertile megaspore. The same investigator makes the general statement that Thuja, Pinus silvestris, and Pinus $P u-$ milio are essentially similar. We have recently discovered this stage in Pinus Laricio (Fig. 106), too late to include the figure at this place. A row of four potential megaspores is very evident, the lowest one becoming functional, the other three appearing for a time as a densely staining cap. In the preparation figured the original wall of the mother cell is sharply defined, but the walls between the disintegrating cells are very indistinct.

In case several mother cells are functional, as in Taxus and Sequoia, several megaspores may begin to enlarge simultaneously, but one soon dominates, and enlarging at the expense not only of the other megaspores, but also of the adjacent sterile tissue, becomes the single very large fertile megaspore of the sporangium. Sometimes the sterile megaspores are somewhat prominent in the nucellus, and in Sequoia Shaw ${ }^{34}$ records them as clustered about the upper third or fourth of the remarkably elongated functional megaspore.

The usnal account of the germination of the megaspore and the development of the archegonia has been derived from the publications of Hofmeister ${ }^{9,12}$ and Strasburger, ${ }^{15,17,21,24,28}$ but recently much has been added in the way of detail. Very early in its history, long before it has attained its fertilization size, the megaspore begins to germinate, and embryo sac * and gametophyte continue growth together until the nucellus is largely replaced. The sequence of events is much the same as

* For convenience we make an arbitrary distinction between megaspore and embryo sac, the former being the true uninucleate spore, the latter the persistent and growing wall of the megaspore, which continues to invest the gametophyte. 
that given for Cycads. The megaspore nucleus divides, and this is followed by repeated simultaneous nuclear divisions until a large number of free nuclei have been organized. According to Jäger, ${ }^{40}$ about 256 free nuclei appear in Taxus baccata before walls are formed. This represents eight successive divisions, and coincides exactly with Hirase's estimate of the free nuclei in the embryo sac of Ginkgo previous to the formation of walls. Very early in this series of divisions, probably in general when but two or four free nuclei have appeared, the nuclei become imbedded in a parietal cytoplasmic layer inclosing a large central vacuole (Fig. 62), and in this position free nuclear division is completed. Subsequent divisions of the nuclei are accompanied by the formation of cell walls and a parietal tissue is organized. From the parietal plate of cells the cavity of the embryo sac is gradually filled with tissue, the faces of the cells directed toward the center in this advance lacking walls. The more compact tissue toward the micropyle organizes archegonia, while the deeper tissue is nutritive.

A deviation from this method of endosperm formation has been reported by Arnold ${ }^{42}$ as occurring in Sequoia. After the development of the free nuclei, the cytoplasmic layer increases in thickness, accumulating especially at the lower end of the sac. Then cell formation occurs in the upper and lower extremities of the sac, while free nuclear division continues in the central region.

About the last of May the archegonium initials become apparent. Within a week the primary neck cell has been cut off, and the central cell has become much enlarged (Fig. 64, A, B). As the archegonia develop, the adjacent endosperm tissue continues to grow, so that a more or less evident depression appears over each archegonium in case they are scattered (Abieteae), or over each group of archegonia in case they are clustered (Cupresseae and Taxodieae). The number of archegonia developed by a single gametophyte varies considerably. In Abieteae there are three to five; in Taxus baccata five to eleven; in Cupresseae five to fifteen, or even thirty. The neck of the archegonium shows much variation. In Cycads and Ginkgo the primary neck cell divides but once, by an anticlinal wall, forming a neck of two cells, placed side by side as are the guard cells of a stoma. In the majority of Conifers observed a plate of four cells is derived 
from the primary neck cell, and by periclinal divisions the single plate becomes two, so that the neck is composed of two tiers of cells with four cells in each tier. The recorded deviations are as follows: in Tsuga Canadensis, 31a, 49, and Cephalotaxus Fortunei the neck is usually two-celled, as in Cycads and Ginkgo; in some Cupresseae eight cells occur in each tier; while in some specis of Pinus and Picea more than two tiers of cells occur, with four or eight cells in each tier.

After the separation of the neck cell from the central cell, the latter begins a remarkable increase in size and receives a
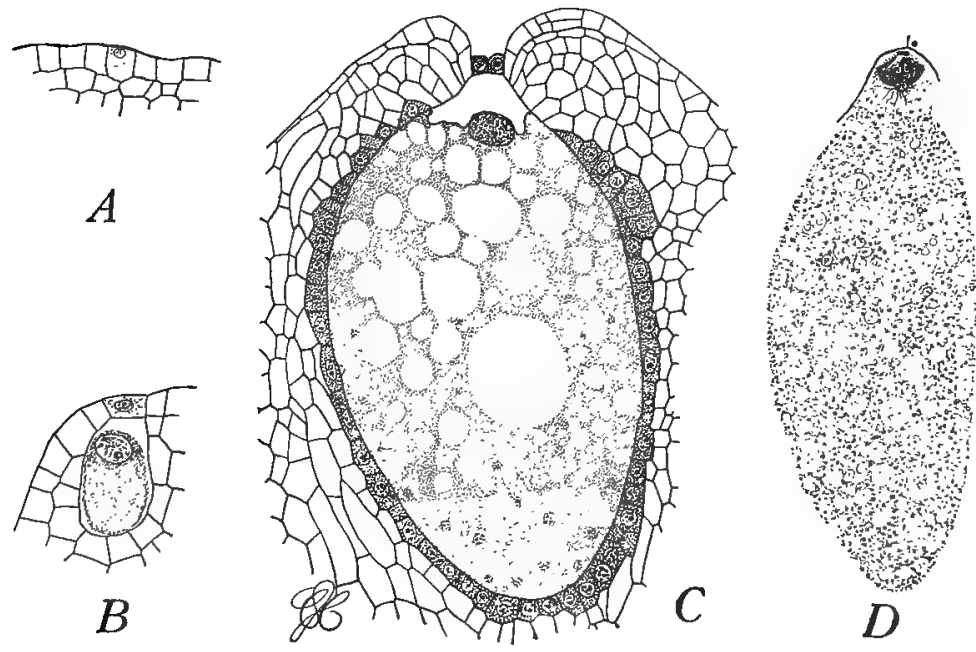

Fio. 64.-Pinus Laricio: $A$, archegonium initial, May 28th; $B$, neck and central cells, June 2d; $C$, central cell just before cutting off the ventral canal cell, June 18th; $D$, cutting off of the ventral canal cell, June 21 st; $\times 104$.

large amount of nutritive material (Fig. 64,C). About it a definite jacket of endosperm cells is organized, resembling the venter of an archegonium. The cells of the jacket become surcharged with protoplasmic material, and their nuclei enlarge, while the wall of the central cell becomes thick and very distinctly pitted. Through these pits Goroschankin ${ }^{26}$ first traced a continuity of cytoplasm between central cell and jacket cells. Very early in its history, at the beginning of its enlargement, the central cell becomes vacuolate, the protoplasmic contents forming merely a wall layer, the nucleus retaining its apical position from 
the time of the cutting off of the neck cell to the cutting off of the ventral canal cell, a period of two or three weeks, beginning between the middle of May and the 1st of June, dependent on the season. The central cell now begins to receive supplies from the jacket cells, which practically empty themselves through the pits. As a consequence, the central cell becomes packed with food material, the cytoplasm being filled with large and deeply staining masses, even more prominent in the egg, the best organized of which have been called " proteid vacuoles." These "vacuoles" of the central cell and egg were regarded by Hofmeister and Goroschankin to be nuclear structures, but Strasburger denied their nuclear nature, and claimed that they are proteid vacuoles, and such they have been regarded ever since, until the recent investigations of Arnoldi. ${ }^{43}$ He observed that the nuclei of the jacket cells become amoeboid, squeeze through the pits, and regain their form in the central cell and egg. Nuclei were also observed to pass from the next outer layer into the cells of the jacket. In addition to these organized nuclei, nuclear fragments and other materials pass in from the jacket cells, which may often be seen emptied of their contents.

The cutting off of the ventral canal cell has been known in a general way since Strasburger ${ }^{24}$ established its existence in Juniperus. The fullest accounts, however, have been given by Blackman ${ }^{37}$ and by Chamberlain. ${ }^{39}$ Just before fertilization, which we find in Pinus Laricio to occur about the 1st of July, the ventral canal cell is cut off (Fig. $64, D$ ). A broad spindle, which is almost rectangular in outline before it becomes bipolar, is organized at the apical extremity of the central cell, and there appears a thin but broad and sinuous cell plate. This cell plate cuts out from the main mass a small oval segment, the ventral canal cell (Fig. 65). After the separation of the ventral canal cell, its nucleus begins to return to the resting stage, but according to Blackman it never reaches it before disorganization sets in. After this the ventral canal cell appears in various stages of disorganization, often separating somewhat from the egg, and has usually disappeared by the time the pollen tube has penetrated the neck of the archegonium, although Chamberlain found occasional traces of it even after the embryo was considerably advanced.

Blackman noted the exact similarity between the nuclei of 
the ventral canal cell and of the egg. He called attention to the fact that the two cells differ from each other only in the quantity of cytoplasm, and concluded that the ventral canal cell
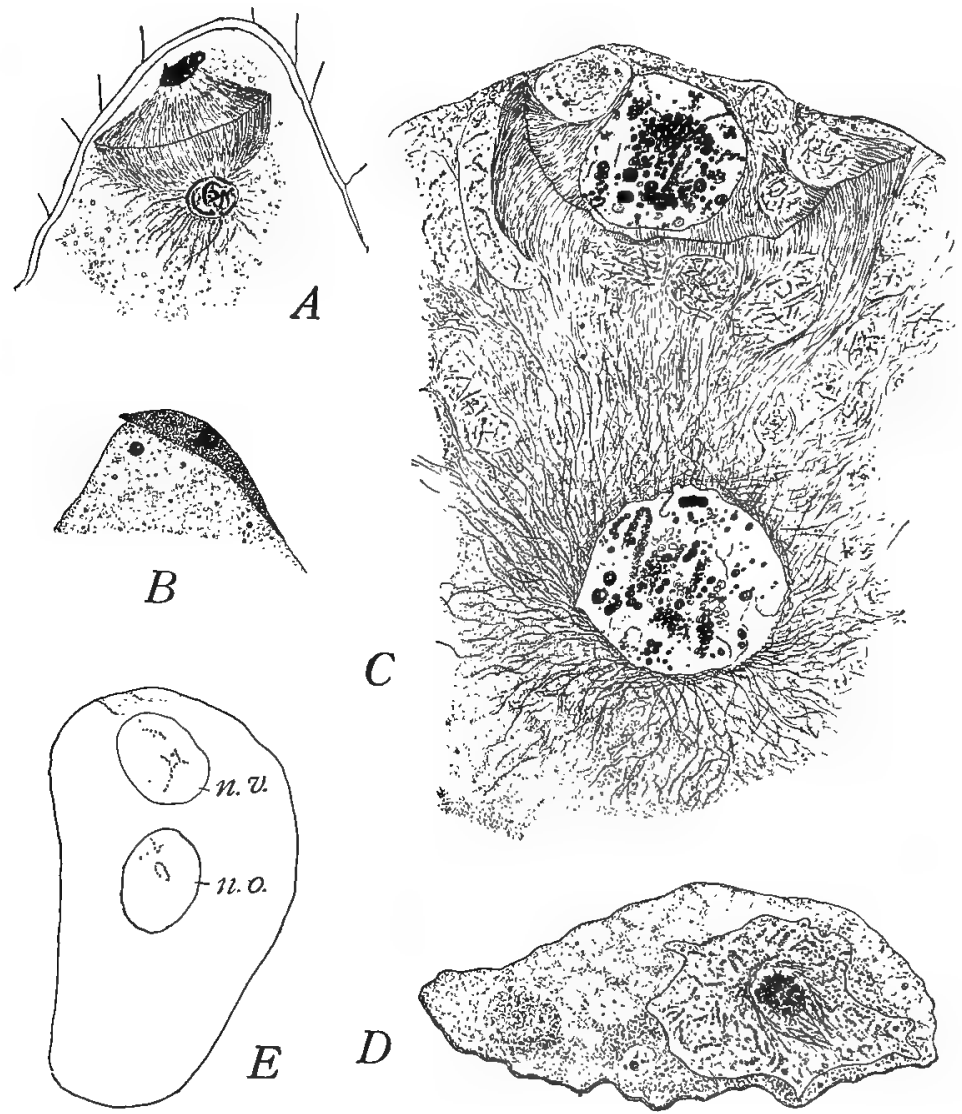

F10. 65.-Pinus Laricio: $A$, the ordinary spindle in cutting off the ventral canal cell; $B$, disorganizing ventral canal cell; $(c$, an unusually litrge spindle in cutting off ventral canal cell, the two nuclei being of the same size and showing the same developenental changes: $D$, a large ventral canal cell; $E$, the wall separating a large ventral canal coll and the egg has broken down ( $n$. v., nucleus of ventral canal cell; n. o., egg nucleus); $A-D, \times 500 .-$ After Chamberilarn.

is evidently an arrested gamete. Chamberlain further strengthened this view by discovering a series in which a ventral canal cell very much larger (" eight to ten times") than usual was cut off (Fig. $65, C, D$ ). Its nucleus had reached the size of the egg 
nucleus, and had passed through the same peculiar developmental changes. To all appearances it was ready for fertilization. The same observer also discovered cases of large ventral canal cells and nuclei in which the cell plates separating them from the egg had disorganized, giving the appearance of two similar nuclei imbedded in the cytoplasm of the egg (Fig. 65, $E$ ). It is very probable that this may explain such cases of equal nuclei as those recorded by Strasburger, ${ }^{22}$ Coulter ${ }^{36}$ (Fig. 66), and others, which were thought to be the male and female nuclei approaching for fusion. In any event, it seems clear that the ventral canal cell represents an abortive egg, which is occasionally organized as an egg, and which may rarely function as one.

In a recent paper by Arnoldi ${ }^{43}$ upon Cephalotaxus Fortunei a curious procedure in reference to the ventral canal cell is recorded. The nucleus of the central cell divides as usual, and a ventral canal cell nucleus is formed, but no regular cell is organized. Instead of this, the upper part of the cytoplasmic mass, containing the ventral canal cell

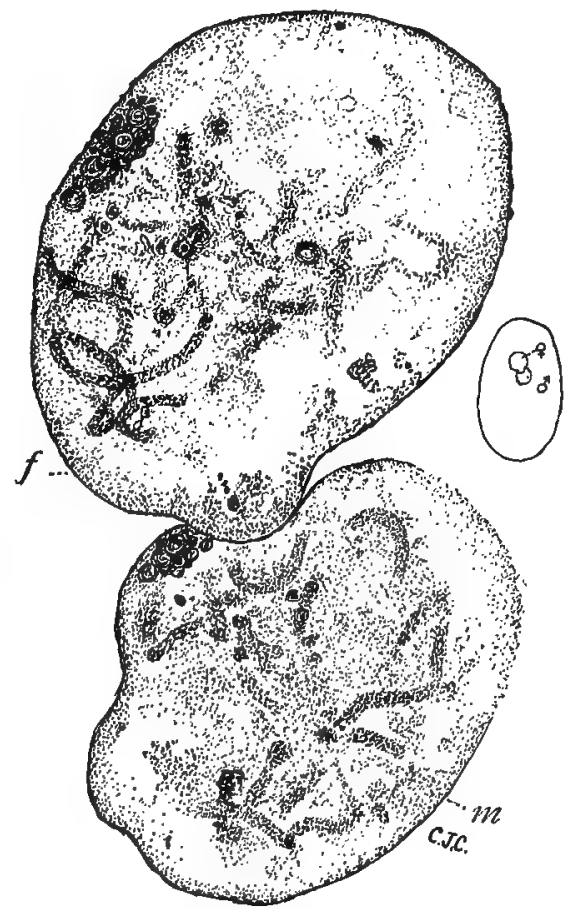

Fra. 66.-Pinus Laricio, conjugation of two nuclei described as male $(m)$ and female $(f)$, but which may prove to be the nuclei of the ventral canal cell and the egg (as in Fig. $65, E$ ); $\times$ 500.-After Coulter.

nucleus, is said to become mucilaginous, breaks down the neck cells (two in number), and is separated from the egg by a pinching-off process. Although there is no real cell formation in the morphological sense, physiologically the result is the same as in other cases, a nucleus and some cytoplasm being separated from the forming egg. 
At the time of its organization, the egg nucleus is no larger than that of the ventral canal cell, or of the nutritive jacket cells, but it begins immediately a very rapid and a very great

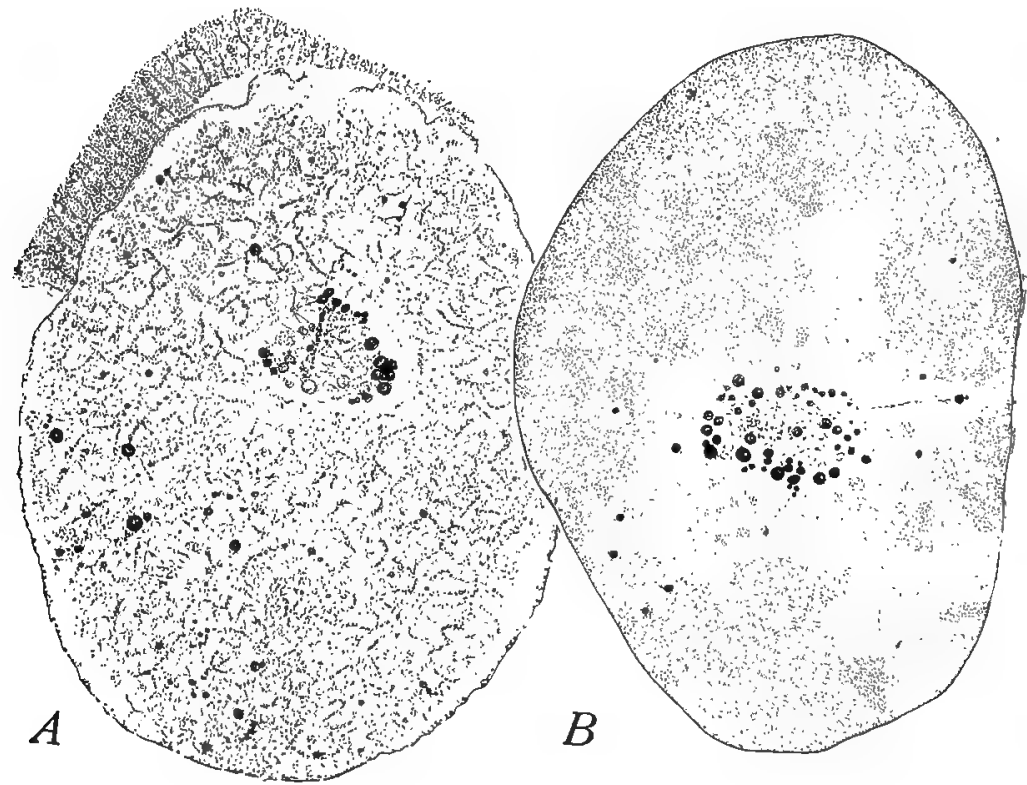

Frg. 67.-Pinus Laricio: Two nuclei showing the collection of the chromatin nucleoli into a definite area; $\times 500$.-After Chamberlain.

enlargement. It moves towards the center of the egg with great. rapidity, and attains a size that seems out of all proportion to its original bulk and to the time employed. During this enlargement changes occur in the nucleus which have been differently interpreted, but which are decidedly at variance with the cytological phenomena observed in the eggs of Angiosperms. The chromatin seems to be very scanty and the nucleoli become numerous. Chamberlain ${ }^{39}$ has concluded that the chromatin takes the form of nucleoli, which finally collect from all parts of the nucleus to a definite area near the center, where they take the form of elongated masses that undoubtedly represent the chromatin of the nucleus (Fig. 67). In the cytoplasm of the egg the nutritive materials derived from the jacket cells become prominent, and among them the nuclei ("proteid vacnoles") are conspicuous. 


\section{THE MALE GAMETOPHYTE}

The male gametophyte of Conifers has long been known in a general way, but Belajeff,, ${ }^{30}$ investigating Taxus baccata and Juniperus communis in 1891 , seems to have been the first to recognize the homologies and functions as at present understood. In 1892 Strasburger, ${ }^{31}$ studying a somewhat wider range of forms, notably Larix and Cupressus, extended Belajeff's conclusions to Conifers in general. This was followed in 1893 by the further studies of Belajeff ${ }^{32}$ upon Taxus and Juniperus. In 1894 Dixon ${ }^{33}$ published a detailed account of the male gametophyte of Pinus silvestris, which was followed by us in 1896 with confirmatory studies of Pinus Laricio. In 1896 Shaw ${ }^{34}$ published partial results of his studies of Sequoia; in 1899 Jäger ${ }^{40}$ investigated Tarcus baccata anew, and with ,abundant material; recently Coker ${ }^{45}$ has published some notes

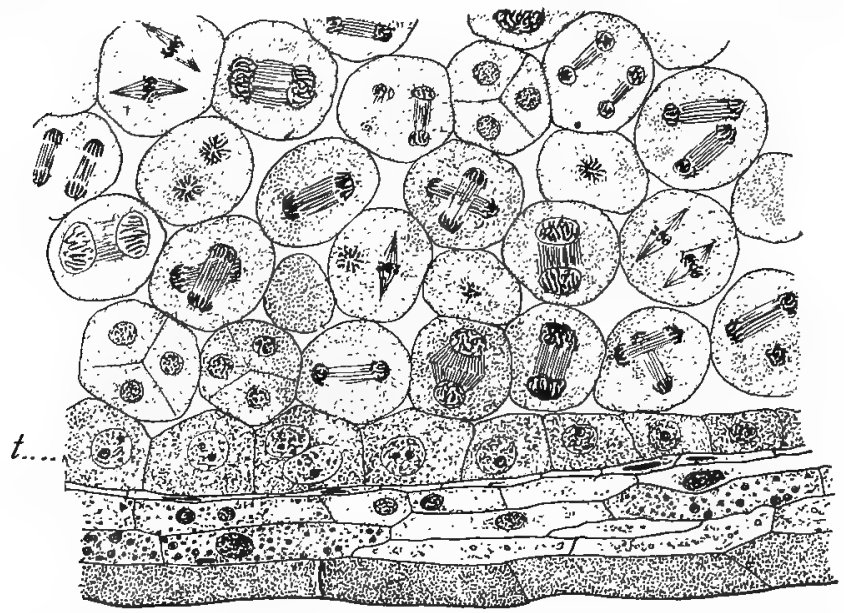

F1a. 68.-Pinus Laricio, showing mitosis in pollen mother cells, May 3d; $\times 500$.

on Taxodium distichum; while Arnoldi ${ }^{43}$ has obtained some interesting results from a study of Cephalotaxus Fortunei. These accounts indicate a fairly uniform series of events, a uniformity somewhat obscured by the varying terminology of the writers. We have secured a very complete series of preparations from Pinus Laricio, and the following account is written from them (Figs. 68, 69). 
The microsporangium passes the winter in the mother-cell stage. About the 1st of May the mother cells are found in various stages of the reduction division. The divisions do not appear to be so simultaneous as in the Angiosperms, for in the same sporangium some mother cells are preparing for the first division, others contain completed tetrads, and others represent every stage between (Fig. 68). In the same sporangium, also, the division may be simultaneous or successive, although the former seems to be the prevailing. method; and they may be tetrahedral or bilateral. As was stated in connection with the female gametophyte, the reduction number of chromosomes in Pinus silvestris and Pinus Laricio has been found to be twelve. In 1892 Strasburger ${ }^{31}$ counted twelve chromosomes in the endosperm of Pinus silvestris. Recently Blackman ${ }^{37}$ has counted the same number in the oosphere, the jacket cells, the ordinary endosperm, and the pollen mother cells; while in the first division of the oospore, and in the embryo, twenty-four were counted. Chamberlain ${ }^{39}$ obtained the same results from Pinus Laricio, counting twelve chromosomes in the jacket cells, the ordinary endosperm, and the pollen mother cells. The wings of the spores begin to develop while they are within the mother cell.

About May 20th the nucleus of the spore enlarges for its first division (Fig. 69, D), a spindle is formed rapidly (Fig. $69, E$ ), and an equal division follows, so far as the mass of chromatin is concerned. Before the cell plate is organized, however, the nucleus nearer to the wall of the spore begins to disorganize, and the other begins to enlarge (Fig. 69, $F$ ). In this way a lenticular and disorganizing cell is cut off against the wall of the spore (Fig. 69, $G$ ). A second division immediately follows, the spindle being observed about May 25th (Fig. $69, H)$. This division is a repetition of the first in details, and the two lenticular cells disorganize rapidly (Fig. 69, $I$ ), become flattened against the spore wall, and very soon appear merely as two thin and darkly staining disks (Fig. 69, J).

It seems reasonable to suppose that these two evanescent cells represent a vestige of the vegetative tissue of the gametophyte, and they may be called properly vegetative cells. It will be remembered that in the Cycads only one such cell is said to appear, and that it persists; while in Ginkgo two appear and the second one persists. 
The third division immediately follows (Fig. 69, J), dividing the large antheridial cell into the primary spermatogenous

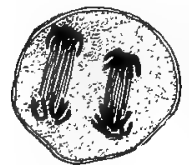

A
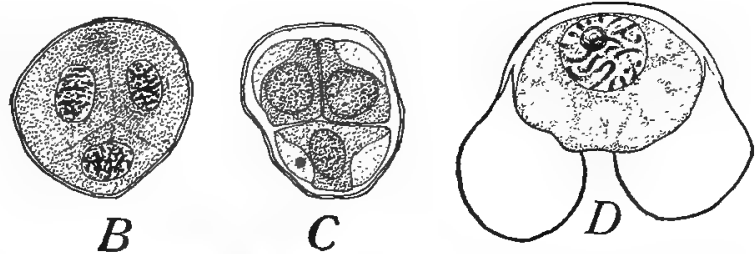

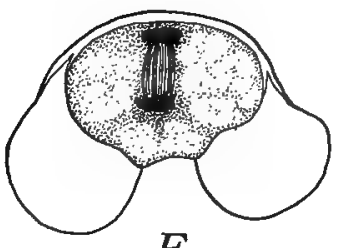

E
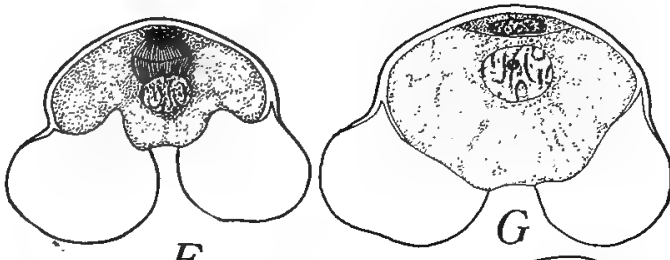

$F$
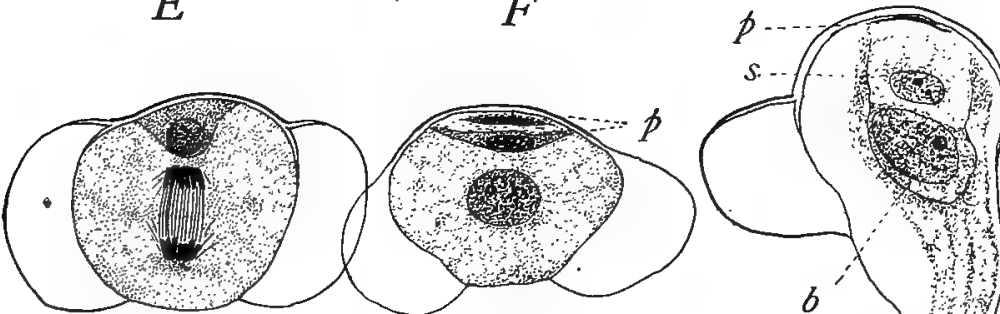

$H$

I
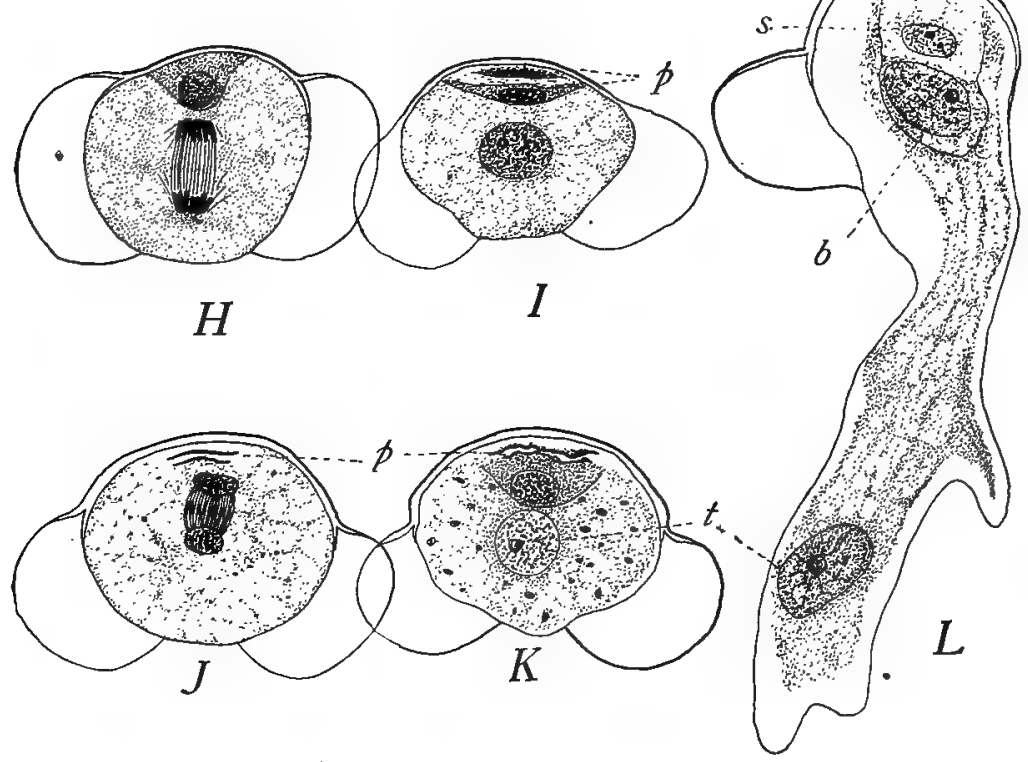

FIG. 69.-Pinus Laricio, showing a series from the formation of the tetrads to the development of the pollen tube : $p$, vegetative cells; $s$, stalk cell; $b$, body cell; $t$, tube nucleus: $A$ and $B$, May $3 \mathrm{~d} ; C$, May 10th; $D-G$, May 20th; $H-J$, May 25th; $K$, June 15th ; $L$, May 1st (nearly a year after stage shown in $K$ ) ; $\times 600$.

cell or generative cell, and the tube cell (the so-called "vegetative cell") (Fig. 69, K). Until 1891, when Belajeff ${ }^{30}$ dis- 
covered the true functions, the more prominent nucleus of the tube cell was regarded as the generative nucleus. By this time the large tube cell has become very full of starch, and no further division occurs until the following spring, a period of about eleven months. In this condition also pollination occurs, and the old spore wall with its con-

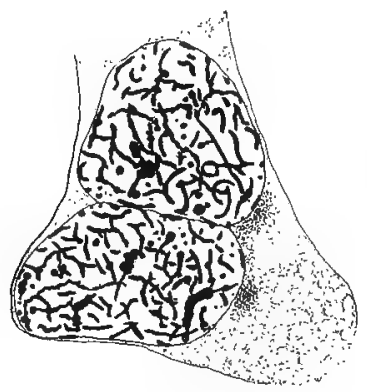

Fia.70.-Pinus Laricio, showing flattened end of pollen tube before discharge into the egg; the two male cells are at the tip and above them, but not shown, are the nuclei of the stalk and tube cells ; $\times$ 500.-After Chamberlain.

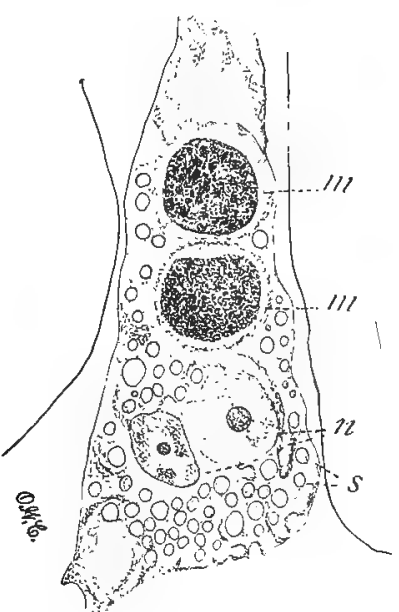

Fig. 71.-Pinus Laricio, showing end of pollen tube just before discharge; the nale cells $(m, m)$ in this case are belind the nuclei $(n)$ of the tube and stalk cells; $s$, starch grains; the pit is evident at the extreme tip; $\times 500$. After' Coulter.

tained gametophyte rests in the cuplike depression at the apex of the nucellus during all this period.

Dixon ${ }^{33}$ says that in Pinus silvestris the pollen tube is sent out into the nucellus as soon as the grain is deposited, and that it passes a year or even more in the upper region of the nucellus, disorganizing the adjacent tissue and producing irregular cavities. This seens to be true of P'inus Laricio also, whose pollen tubes we have found in the nucellus in June. Coker reports that in Taxodium distichum, however, the pollen tube, sent out immediately after pollination, penetrates to the archegonia without interruption. See Appendix.

The pollen tube in Pinus begins to renew its penetration of the nucellus during April, about a year after the mother cell entered upon the reduction division, the large tube nucleus enters the tuhe, where it is completely invested by starch grains, and at the same time the generative cell divides into 
the stalk cell and body cell (Fig. $69, L$ ). In this case the two cells, so far as we have observed or seen figured, are "fore and aft" with reference to each other, and not side by side, as in Cycads and Ginkgo, the stalk cell being nearer the old spore wall. It appears, therefore, that the generative cell persists for about eleven months without dividing. The pollen tube branches as it traverses the nucellus, not so extensively as do the tubes of Cycads and Ginkgo, but sufficiently to give evidence of its primitive service as an absorbing or rhizoidal organ. It consumes about two months in traversing the nucellus after its second start, entering the archegonium about the 1st of July.

The liberation and descent of the body cell into the tube, accompanied by the freed nucleus of the stalk cell whose wall has been ruptured, and their association with the tube nucleus near the tip of the tube, has been described in detail by Dixon for Pinus silvestris, and his account applies as well to $P$ inus Laricio, except that we find no definite order of arrangement in the relative positions of these three bodies.

Just before fertilization, about two months after the division of the generative cell into stalk and body cells, the latter divides and forms the two male cells (morphologically sperm mother cells). It is this division which in the Cycads is accompanied by the appearance of blepharoplasts, and

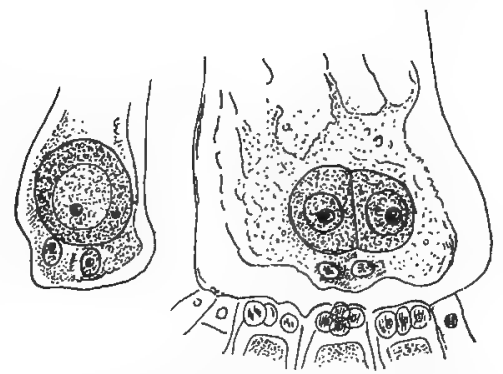

FIG. 72.-Juniperus Virginiana, showing the ends of two pollen tubes; in the tube to the left the body cell has not yet divided; in the other the division into two male cells has just taken place; in both cases the nuclei of the tube and stalk cells are in front; $\times$ 160.-After STRASBURGER. results in the organization of two ciliated male cells. So far as observed, however, blepharoplasts do not appear in Conifers and the male cells do not become ciliated. This is doubtless associated with the fact that in Conifers the pollen tube has become a sperm carrier, while in the Cycads it performs no such function. At the time of fertilization, besides dense cytoplasm rich in starch, the tip of the pollen tube contains four bodies, namely, tube nucleus, stalk cell nucleus, and the two male cells (Figs. 70-72). 
The recorded variations from the above account are as follows: In the work upon Taxus, Juniperus, Cupressus, and $S e^{-}$ quoia no mention is made of the two ephemeral vegetative cells. They are so evanescent, however, that they may well escape the notice of any observer who does not have a very close series and good preparations. In Taxus Belajeff ${ }^{30}$ observed that the body cell divides unequally, the larger male cell functioning, and the smaller one remaining in the tube during fertilization, apparently incapable of functioning (Fig. 73). In this he was confirmed by Strasburger, ${ }^{31}$ and very recently by Jäger. ${ }^{40}$ It is in-

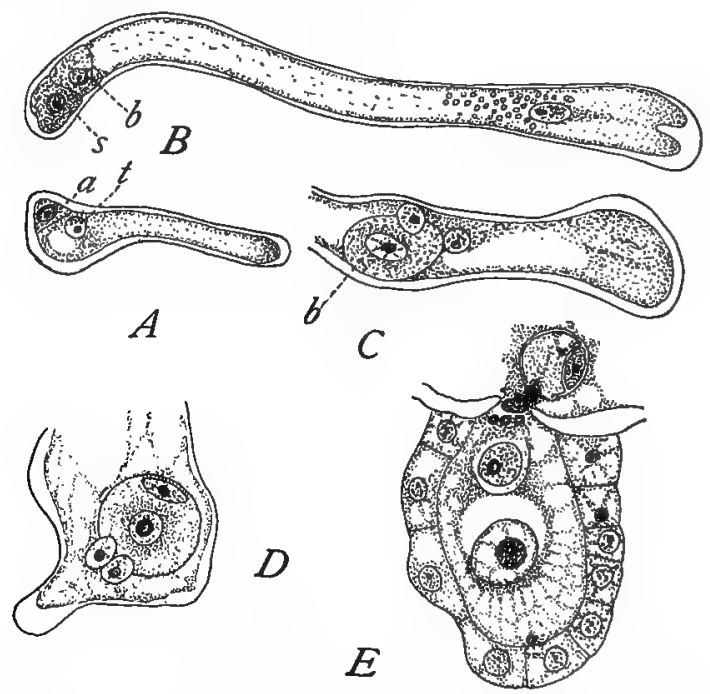

FiG. 73.-Taxus baccata: $A$, male gametophyte, showing generative cell (a), tube nucleus $(t$ ), and young tube (April 10th); $B$, later stage of same, showing stalk $(s)$ and body $(b)$ cells; $C$, the Iarge body cell passing into the tube, accompanied by the nuclei of the tube, having dividecl into two very unequal male cells; $E$, the larger male cell discharged into the egg; $A-C \times 230, D$ and $E \times 180$.-After Beladefr.

teresting to note that in Arnoldi's recent work on Cephalotarus Fortunei, ${ }^{+3}$ a genus apparently very closely related to Taxus, the two male cells are shown to be of the same size and apparent vigor. In Sequoia Shaw ${ }^{34}$ observed that the pollen tube does not penetrate the nucellus immediately, but advances across its flat top and turns downward between it and the integument, branching freely. Finally, one branch turns into the nucellus about one fifth down its length, penetrates obliquely downward 
and enlarges, and presently becomes indistinguishable among the numerous tortuous sterile megaspores which cluster about the upper end of the elongated fertile one. The branches of the tube which remain external to the nucellus advance in every direction between it and the integument. Such a condition of things suggests the free branching rhizoidal habit of the tubes of Cycads and Ginkgo, although in them the branching is within the body of the nucellus. See Appendix.

FERTILIZATION

The tip of the pollen tube, having penetrated the overlying tissue of the nucellus, reaches the wall of the embryo sac, and either passes directly through it or flattens out upon it in a footlike expansion, sending out a small branch to pierce the wall. In any event, the tube, or a branch of it, reaches the neck of the archegonium, crushes the neck cells, and comes in contact with the egg.

This contact may be regarded as the beginning of the process of fertilization, which ends with the fusion of the sexual nuclei. Jäger ${ }^{40}$ reports that in Taxus baccata the tube reaches the egg about June 1st; Coker ${ }^{45}$ states that the date for Taxodium distichum is about June 15th; the same date is given by Arnoldi ${ }^{43}$ for Cephalotaxus Fortunei; while in Pinus Laricio we find the date to be about July 1st. Of course the dates vary somewhat with the season and with the latitude.

It has been shown by Blackman ${ }^{37}$ and confirmed by Chamberlain ${ }^{39}$ that the tip of the tube becomes fused with the egg membrane, and does not enter the cytoplasm, as usually stated. The appearance of an elongated and well-defined cavity in the cytoplasm of the upper part of the egg is due to the inrush of the contents of the tube (Figs. 74, 76, B).

The pit in the tip of the tube was described by Hofmeister, ${ }^{5}$ Strasburger, ${ }^{15}$ and others, but they claimed that it remains closed by the primary wall membrane. In 1883 Goroschankin ${ }^{26}$ stated that he saw the pit perforated in Pinus Pumilio, which was fully confirmed by Dixon ${ }^{33}$ in Pinus silvestris, and by Black$\operatorname{man}^{37}$ in the same species (Fig. 71). Nearly the whole of the contents of the tube is injected into the cytoplasm of the egg. In Pinus Pumilio, Goroschankin ${ }^{26}$ observed both male cells pass in, and Strasburger ${ }^{28}$ confirmed it for Picea vulgaris. Dixon ${ }^{33}$ 
seems to have been the first to see all the four structures in the pollen tube injected into the egg, an observation which has been frequently confirmed since. It should be remembered, however, that in the case of Taxus baccata Belajeff ${ }^{30}$ reports the passing into the egg of a single male cell only, the smaller one remaining in the tube. In Pinus, in Taxodium as shown by Coker, ${ }^{45}$ and in Cephalotaxus as shown by Arnoldi, ${ }^{43}$ the upper

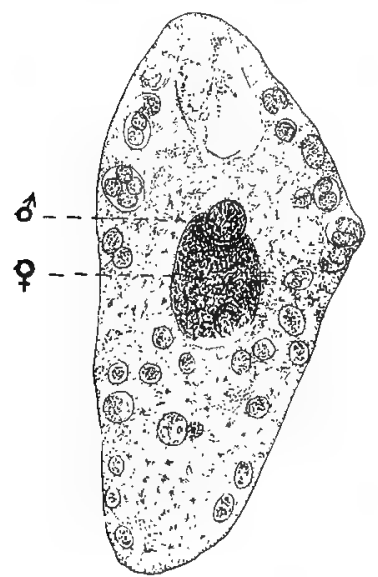

Fig. 74.-Pinus silvestris, the male nucleus entering the fenale nucleus (June 19th); $\times$ 135.-After Bladomar. part of the cytoplasm of the egg, after the discharge of the tube, contains two male cells, the disorganizing tube nucleus and stalk cell nucleus, besides cytoplasm of the tube and starch grains. The cytoplasm of the male cells is no longer distinguishable, and their nuclei may be recognized by their large size and more deeply staining contents as compared with the tube and stalk cell nuclei, which can hardly be distinguished from each other.

One male nucleus moves forward through the cytoplasm of the egg, the other three injected bodies remaining near the top of the egg and gradually disappearing. Arnoldi ${ }^{+3}$

makes an interesting observation in connection with the functionless male cell in Cephalotaxus Fortunei. He reports that as it lies unused in the peripheral region of the cytoplasm of the egg it may divide amitotically, one of his figures showing six nuclei as having been derived from a single functionless male nucleus. According to Blackman, ${ }^{37}$ the functional male nucleus moves very rapidly and increases in size, an increase apparently due in some cases to actual increase of stainable substance, and in others to vacuolation. The male nucleus of Pinus is nearly spherical, with a diameter of about $40 \mu$, and is usually one third (rarely one half) the diameter of the ellipsoidal or eggshaped nucleus of the egg.

The behavior of the male nucleus after it reaches the eg $\mathrm{gu}$ cleus is peculiar (Fig. 74 ). According to Blackman, it pushes in the membrane of the egg nucleus, and finally comes to lie within 
it, both walls being intact. At this time similar changes occur in the contents of both nuclei, and the spindle of the first segmentation begins to organize while the two nuclei are still distinct. Blackman claims that no resting fertilized nucleus is ever formed, although in all other known plants the male and female nuclei fuse while in the resting condition and form a definite resting fertilized nucleus. Chamberlain confirms this so far as to state that the two nuclei are in the spirem stage after the male nucleus has entered the female nucleus (Fig. 75). Woycicki ${ }^{41}$ has also observed in Larix Dahurica that in some cases after the coalescence of the two nuclei two separate chromatin groups are to be distinguished, one of which he would regard as the male, and the other the female group. Such behavior finds its parallel among animals, as in $A s$ caris, * but not among plants, so far as known. The process of fusion is exceed-

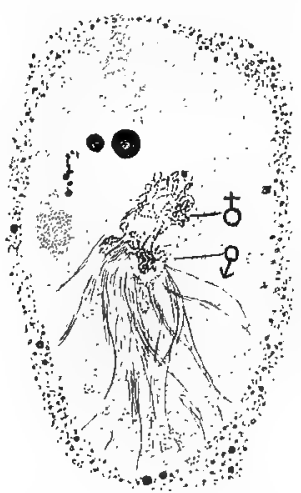

Fig. 75.-Pinus Laricio, the chromatin of the male and female nuclei in the spirem stage within the limits of the female nucleus; $\times$ 500.-After CHAMBERLAIN. ingly slow, according to Blackman beginning when the male and female nuclei begin to react upon one another, and closing when the half chromosomes, derived from the male and female nuclei respectively, fuse at the poles of the first segmentation spindle. See Appendix.

Some minor deviations from this account of Blackman, given for Pinus, have been observed by Coker ${ }^{45}$ in Taxodium distichum, and by Jäger ${ }^{40}$ in Taxus baccata. In the former the two nuclei come in contact near the upper end of the egg and travel together toward the base, not fusing completely till the

* “In Van Beneden's epoch-making work on Ascaris it was shown not only that the nuclei do not fuse, but that they give rise to two independent groups of chromosomes which separately enter the equatorial plate and whose descendants pass separately into the danghter nuclei. Later observations have given the strongest reason to believe that, as far as the chromatin is concerned, a true fusion of the nuclei never takes place during fertilization, and that the paternal and maternal chromatin may remain separate and distinct in the later stages of development-possibly throughout life."-Wilson's The Cell in Development and Inheritance, second edition, p. 204. 
bottom is nearly or quite reached. In Taxus there is the same passing of the paired nuclei to the bottom of the egg for fusion, and they are also reported as being of the same size. Perhaps it is well to call attention to the fact that two free nuclei from the early divisions of the fusion nucleus might be mistaken for male and female nuclei unless the latter had been previously observed and their great difference recognized. These free nuclei are of the same size and pass to the bottom of the oospore. It is also very possible that in some cases the ventral canal cell is fertilized rather than the egg; and there are some grounds for believing that the nuclei of the ventral canal cell and of the egg may fuse, suggesting what has been observed among animals in cases of parthenogenesis (Wilson, loc. cit., pp. 280-283).

\section{THE EMBRYO}

The first adequate account of the development of the embryo in Conifers was that given by Strasburger in 1872.17 Later the same author ${ }^{24}$ published more fully upon the subject, and several investigators since have touched upon the embryogeny of Conifers; but the whole subject is in need of more detailed investigation. While the earlier stages of the embryo are fairly well known, our knowledge of the development of the embryo proper is little more than an outline. We have obtained a complete series of the early stages in Pinus Laricio, and from it the following account is written.

1. Development of Proembryo.-The fusion nucleus retains its central position in the cytoplasm of the oospore (Fig. 76, A), and, beginning to divide, organizes the largest spindle of the free nuclear series (Fig. 77), as in Cycads and Ginkgo. The axis of this spindle is always inclined to the long axis of the archegonium, and its fibers are not at all convergent, resulting in a broad rectangular outline. The two daughter nuclei are very small at first, but increase rapidly in size, and then simultaneously divide. The four free nuclei which are formed by this second division are at first very small, but increase in size both through vacuolation and by taking in substance (Fig. $76, B$ ). When the four nuclei have reached their full size, they begin to move toward the base of the spore, and at this time show an investment of strong fibers, which 
are directed tangentially. Chamberlain ${ }^{39}$ thinks that this tangential direction of fibers is caused by the rotation of the nuclei

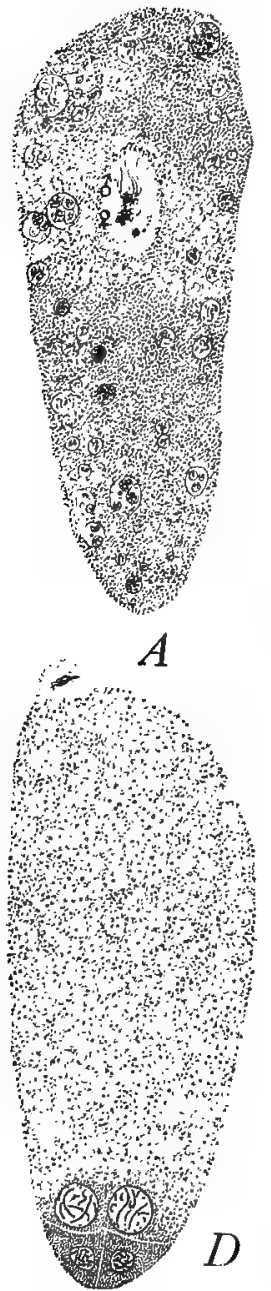

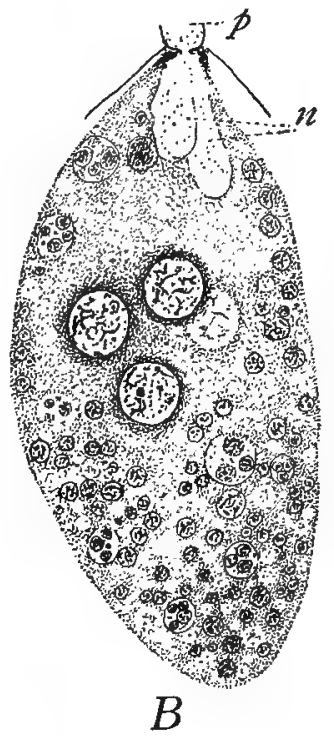

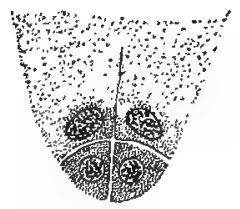

$E$

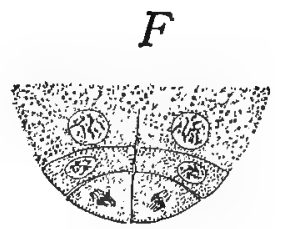

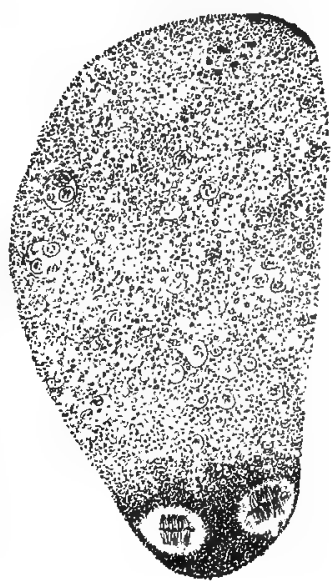
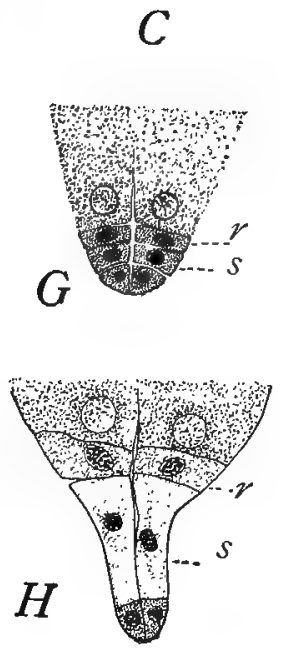

Fra. 76.-Pinus Laricio, early gtage in the development of the embryo: $A$, fusion of male and female nuclei; $B$, the first four nuclei of the proembryo, also numerous nuclei from the jacket cells ( $p$, pollen tube; $n$, cavities caused by inrush of contents of pollen tubes); $C$, the four nuclei at the base of the egg and dividing; $D$, the first plate of four cells : $E$, a somewhat later stage, showing partial cleavage of the main mass of the egg; $F$, two plates of cells, the lower cells in process of division; $G$, the three tiers of cells of the completed proembryo, with the four free nuclei above them ( $r$, "rosette" tier; $s$, suspensor tier); $H$, the suspensor tier ( $s$ ) beginning to elongate; $A-C$ collected June 25 th, $D-G$ July $2 d$; $\times 104$. 
as they descend. Upon reaching the base of the oospore the four nuclei arrange themselves in a plane and become ensheathed by fibers derived from the nuclear membrane. Two walls are then formed at right angles to each other and to the base of the spore, each nucleus thus being separated from the others, but freely exposed above to the general cytoplasm of the spore. Blackman ${ }^{37}$ speaks of " each nucleus thus being at the bottom of a kind of shaft that opens above," and the same author thinks that the ensheathing fibers, which disappear at this time, have some intimate connection with the formation of the walls. In any

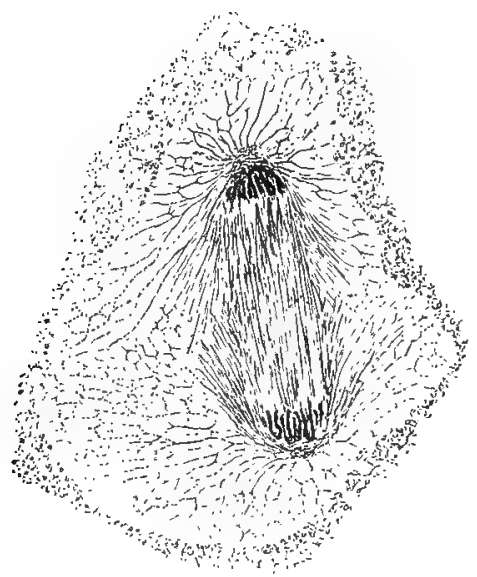

FIG. 77.-Pinus Laricio, the first division of the nucleus of the oaspore; the entire mitotic figure is intranuclear; $\times$ 500.-After Chamberlain. event, the appearance of these first incomplete walls is quite apart from nuclear division, and the incomplete segmentation of the cytoplasm presents a peculiarity which is paralleled in the yolked eggs of certain animals. In fact, the method of receiving food supply into the egg, the organization of a small group of cells to develop the embryo, the setting aside of the great mass of the oospore as a nutritive supply, and the appearance of the peculiar walls about the basal nuclei segmenting more or less the cytoplasmic mass but not cutting it off, are facts which are all more suggestive of the embryogeny of certain animals than of other plants. Chamberlain observed one case in which the first and second segmentations of the fusion nucleus were accompanied by walls, a four-celled group thus appearing near the center of the oospore.

According to our' observation, the walls which separate the four primitive nuclei, as mentioned above, do not appear until after the nuclei are in an advanced stage of division (Fig. $76, C$ ). The spindles formed by the four basal nuclei are extremely broad and multipolar, but the later spindles are definitely bipolar. The basal nuclei divide simultaneously in a plane transverse 
to the long axis of the oospore, a tier of four completely walled cells thus being cut off below (Fig. 76,D), the upper nuclei still being freely exposed above to the partially segmented cytoplasm of the spore (Fig. $76, E$ ), and increasing very much in size. The cells of the single completely walled tier then divide simultaneously, and two tiers are organized (Fig. 76, $F$ ). The process is again repeated by the lower tier, and the result is three tiers of four cells each (Fig. 76, G). With the appearance of this last tier the development of the proembryo ceases. At this stage, therefore, there are three complete tiers, with four cells in each tier, and above these completely walled cells there are the four nuclei separated from one another by walls, but freely exposed above to the food supply of the spore. By their size and generally active appearance it would seem that they must continue functional for some time in connection with nutritive work.

It will be noted that the proembryo in Conifers differs from that in Cycads in the fact that free nuclear division is much restricted, resulting usually in a group of four nuclei rather than a great number; that as a result there is no development of tissue in a parietal position; that the tissue developed at the base of the oospore is more definite and limited as to number of cells and their functions. At the same time, the evidence seems clear that the proembryo of Conifers must have been derived from just such a condition as is shown by the proembryo of Cycads and Ginkgo.

While this account probably applies in outline to Conifers in general, there are differences in certain details which are suggestive. The outline which seems to apply to all Conifers is as follows: the development of free nuclei from the fusion nucleus, the placing of these nuclei in a plane at the bottom of the oospore, the appearance of incomplete walls separating the nuclei from one another but permitting their free exposure to the nutritive mass above, the development from this plate of nuclei of three tiers of completely walled cells, the development of the embryo from the lowest tier of cells, the development of the suspensor from the middle tier, and the retention of the uppermost tier in the oospore.

The details which differ from those given in the above account for Pinus are as follows: Recently Arnoldi ${ }^{43}$ has de- 
scribed a most interesting modification in the formation of the proembryo in Cephalotaxus. The egg nucleus "divides three or four times," which means the production of eight or sixteen free nuclei. These nuclei pass to the bottom of the oospore and divide further, giving rise to " a number" of free cells, which organize tiers "as in Taxus." Just how these numerous free cells organize the tiers the author does not state, and his figures indicate that the condition of his preparations would forbid any claim beyond the mere existence of tiers. The number of free nuclei and cells, however, before the organization of tissue, is the important point, and indicates what would seem to be the most primitive embryogeny among the Conifers. Although normally in Pinus an embryo is developed at the end of each suspensor cell-that is, a single oospore gives rise to four embryos-we found in $P$. Laricio cases of a single embryo developing from the plate of four cells carried down by the four suspensors. It seems that this is the normal behavior in Picea excelsa, in which the suspensors remain coherent, forming a single compound suspensor at the end of which a single embryo develops. So far as the records go, the development of a single embryo from the embryonal plate seems to be true in all groups excepting Abieteae. Among the Cupresseae it is reported that each of the three tiers of the proembryo is originally a single cell, either remaining so, as in Cupressus, or dividing, with the exception of the embryonal cell, as in Thuja, or all dividing, as in Juniperus. If this sequence of events be true, it would seem to follow that in these cases the fusion nucleus passes to the bottom of the oospore without division, and there behaves in building up tiers just as do the four basal nuclei in the case of Pinus. Such statements, however, need further investigation. The number of cells in each tier may also vary from four, the usual number in Taxus being six, and sometimes reaching even ten.

2. Development of Suspensor.-The suspensor, or rather the four suspensors, are formed by the remarkable elongation of the cells which form the middle tier (Fig. 76, H). The lowest tier is thus carried down into the midst of the endosperm, and the uppermost tier remains in the base of the oospore, forming the so-called "rosette" of Schacht. The suspensors become long and tortuous (Fig. 78, A), and each bears at its tip one of the 
four cells of the embryonal tier, each of which begins the development of an embryo.

In many Conifers the appearance of embryonal tubes is a prominent feature. These tubular processes are developed from basal cells of the embryo, and seem to serve as additional absorbing organs (Fig. 78, B). They are found investing the suspensor and the base of the embryo, and are sometimes exceedingly numerous.

3. Development of Embryo.-Concerning the development of the embryo proper our knowledge is meager. In every case, with the exceptions noted below, it is developed from the lowest cell or tier of cells at the base of the oospore, the tier which is carried down by the suspensor. As has been stated, the cells of this embryonal plate, usually four or six in number, may together organize a single embryo, or in Abieteae each one is more apt to develop separately. We observed one case in Pinus Laricio which may serve to indicate the possibilities in connection with the devel-

Fig. 78.-Pinus Laricio, showing young embryo: $A$, two young embryos with long suspensors; $B$, an older embryo, showing three embryonal tubes.

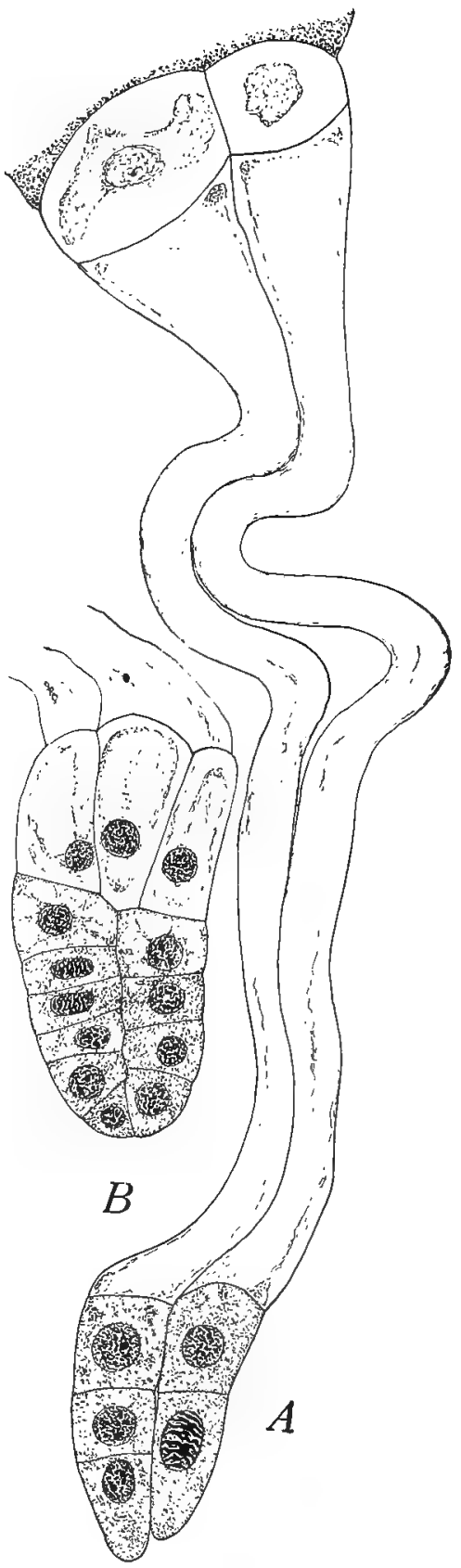


opment of embryos. At the end of a single suspensor two embryos had begun to develop, the first division of the embryonal cell having been longitudinal, and the two daughter

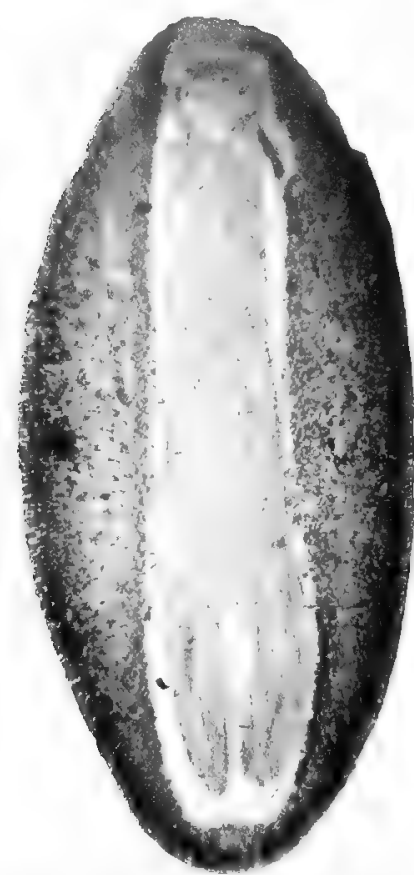

Fie. 79.-Pincs Laricion a fully developed embryo imbedded in the endosperm. cells having become so organicdily dissociated that they pursued their further history independently. The embryo may thus start with a plate of cells or with a singie cell, and hence there is probably no very definite sequence of events. In the case of embryos which develop from a single cell, the first two or three divisions are usually transverse (Fig. 78), although cases have been found in which the first wall is vertical. II'hether' there is any definite sequence of events or not between these early stages of the embryo and the organization of its great regions (Fig. 79 ) is uncertain, but it is probable that the behavior of these primitive cells may be exceedingly variable, dependent upon conditions which have not yet been recognized.

The current statements as to the structure of the root and stem tips of Gymnosperms have been derived mainly from Strasburger. $^{17}$ In reference to the root tip this author states that in Gymnosperms in general the differentiation of meristem at the apex of the root is essentially different from that of Angiosperms. A full statement of the difference was given under the root. The differentiation of the regions at the apex of the stem shows considerable variation in Grmnosperms. As was remarked under the stem, in Dammara, Cunninghamia, and certain species of Aracaria, the dermatogen, periblem, and plerome are clearly distinguishable at the very apex; while in the Alietere the three regions merge in a common group of initials, a character shared by the Cycads. It is interesting 
to note that in Ephedra, even in the same species ( $E$. campylopoda), both conditions are found.

Strasburger ${ }^{24}$ records a remarkable embryonic structure in Cephalotaxus Fortunei and Araucaria Brasiliana. The stem tip, instead of being absolutely terminal, is covered by a small group or layer of cells which is soon thrown off, but seems for a time to serve as an organ of penetration and protection, finding it's analogue in the root cap (Figs. 80, 81). The presence of this terminal group is reported to result in a shifting of the functions of the tiers of the proembryo (Fig. 80). The lowest tier, which ordinarily develops the embryo, in these cases organizes an embryo cap; the middle tier, which ordinarily develops the suspensor, organizes the embryo; the uppermost tier, or "rosette" of Schacht, develops the suspensor; while a fourth tier, apparently organized by the uppermost nuclei which are exposed above to the cytoplasm of the spore, functions as the rosette. It is evident that the statement sometimes made that the stem tips of these peculiar embryos are "endogenous" is not true in the same sense that roots are endogenous.

The recorded numbers of cotyledons are as follows: two in Taxaceae, in $\mathrm{Cu}-$ presseae generally, and in some species of Araucaria; three to five in some Cupresseae; four to nine in Taxodieae; and five to fifteen in Abieteae.

Seed and Fruit.-The origin of the testa is but little known in detail, but the region of its development may be seen in Fig. 82. In Pinaceae it is hard throughout, while in Taxaceae it is accompanied usually by a fleshy layer, or by a fleshy aril. In Podocarpus and Cephalotaxus the seed covering consists of a fleshy outer layer and an inner hard one, as in the seeds of Cycads 
and Ginkgo; while in Taxus, Dacrydium, and Microcachrys the hard coat is surrounded by a fleshy aril. The dry seeds are also frequently winged, either by an outgrowth from the testa or by flakes split from the ovuliferous scales.

Changes following fertilization also occur beyond the boundaries of the seed, and result in a more or less definite fruit.

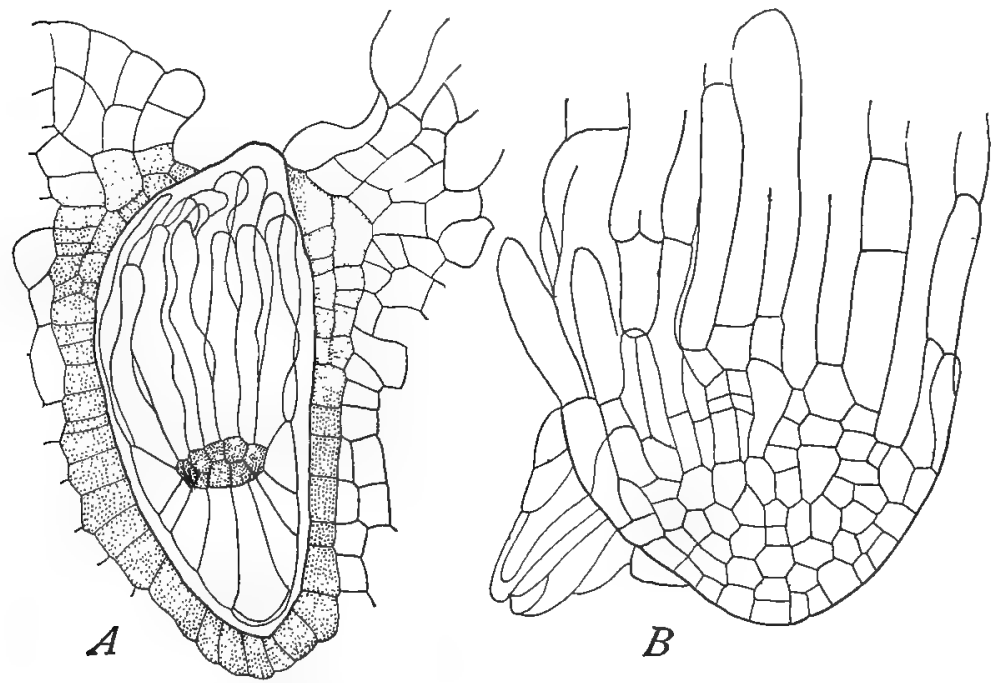

Fig. 81.-Araucaria Brasiliana: A, a proembryo filling the entire oospore, only the shaded cells belonging to the embryo proper, the wedge-shaped mass of cells below being the embryo cap: $B$, a later stage, showing the embryo cap thrust aside; $\times 153 .-$ After STrasburger.

The bracts or scales, or both, are affected, enlarging more or less extensively, and becoming either woody, as in Ibicteae, or fleshy, as in Juniperus; while in Podocarpus sometimes the whole strobilus becomes fleshy.

\section{THE CLASSIFICATION OF CONIFERS}

Our knowledge of the morphology and history of Conifers is not sufficient to justify much certainty as to their classitication. Probably the scheme proposed by Eichler and Engler in Engler and Prantl's "Natürlichen Pflanzenf:milien" is the best expression of our present knowledge, at least it seems best adapted to the purpose of this book. There is general agreement that 
there are at least two great divergent families of Conifers, the Taxaceae and Pinaceae, differing from each other not only in certain important morphological characters, but also in gencral geographic distribution.

The Taxaceae are characteristically south temperate forms, and include only about seventy-one species. Generally true strobili are not organized, at least they do not conceal the ovules, which are freely exposed. This would seem to diminish the chances of pollination as compared with the arrangement in Pinaceae, where the scales are of some service in catching pollen. Moreover, the seeds always develop a partially fleshy testa or an aril, which seems to be correlated with their exposed condition.

The Pinaceae, on the other hand, are characteristically north temperate forms, and include about two hundred and twentyfour of the two hundred and ninety-five known species of Conifers, and in individual or forest display the difference is much greater. Some explanation of this more favorable adaptation to present conditions may be found in the fact that the organization of true strobili not merely protects the ovules, but also increases the chances for pollination. In the maturing of the seed the testa is woody or leathery, with no fleshy development, such as is characteristic of Cycads and Ginkgo, and of the Taxaceae, not even in the form of a fleshy

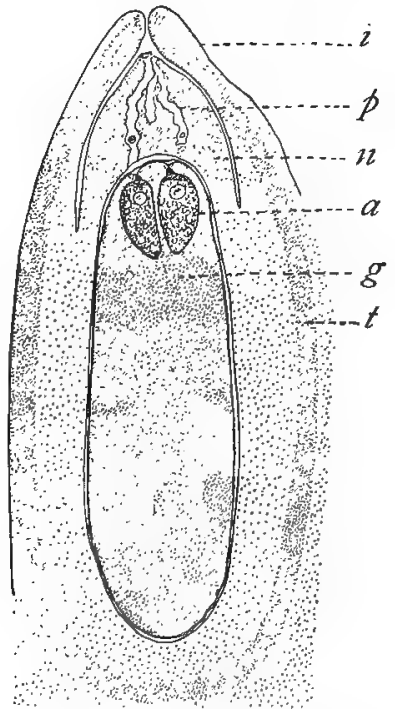

Fig. 82.-Pinus Laricio, longitudinal section of the ovule showing the beginning of the testa (shaded zone): $i$, integument ; $p$, pollen tubes; $n$, nucellus ; $u$, archegonium : $g$, endosperm; $t$, testa $\times 14$.

aril. With such characters, and also with the northern distribution, the Pinaceae stand out quite distinetly.

The Taxaceae, with their exposed ovules and succulent seed investment, contain but eight of the thirty-five genera of Conifers, and only seventy-one of the two hundred and ninety-five 
species. Of these seventy-one species, forty belong to the single genus Podocarpus, as characteristic of the south temperate regions as $P$ inus is of the north temperates. At least two series of Taxaceae are evident, the Podocarpeae and the Taxeae. In the former, containing fifty-four species, the ovules are apparently foliar and the pollen grains are winged; while in the latter, containing seventeen species, the ovules are apparently cauline and the pollen grains are wingless.

The Pinaceae display at least four distinct series of forms, in three of which (Araucarieae, Abieteae, and Taxodieae) the spiral leaf arrangement prevails throughout, in bracts and sporophylls as well as in the ordinary leaves; and in one (Cupresseae) the leaf arrangement is cyclic throughout. The Araucarieae, containing about fourteen species, and prominent in the southern hemisphere, have almost completely coalescent bract and scale, solitary ovules, and free pendulous pollen sacs. The Abieteae, containing about one hundred and twenty-two species and forming the prominent coniferous forest display of the northern hemisphere, have almost completely distinct bract and scale, winged pollen, and needle leaves. The Taxodieae, containing about twelve species, have almost completely coalescent bract and scale, and wingless pollen. The Cupresseae, containing seventy-eight species, are distinguished from the other groups of Pinaceae by the cyclic character, and may have the strobili ripening hard or fleshy (as in Juniperus).

The morphological evidence seems to point to the belief that the Taxaceae represent the more primitive forms of Conifers, and that among the more recent Pinaceae the Abieteae, and notably the genus Pinus, stand for the most specialized forms.

A tabulated statement of the classification outlined above is as follows, the numbers following each genus indicating the approximate number of recognized species it contains :

\section{A. TAXACEAE}

\section{Podocarpece}

1. Saxogothaea........... 1| 3. Podocarpus ........... 40

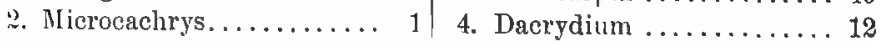

II. Traxeae

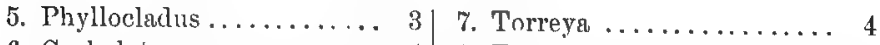

6. Cephalotaxus ......... 4 4 . Taxus ............... 6 
9. HoFmeister, W. Vergleichende Untersuchungen. English translation. 1862.

10. OERSTEd, A. S. Bidrag til Naaletroeernes Morphologi. Videnskab. Meddelelser Nat. Foren. Copenhagen. 1864.

11. Parlatore, F. Studi Organografici sui Fiori e sui Frutti delle Conifere. Opuscula botanica. 1864.

12. Hofmeister, W. Lehre der Pflanzenzelle. $186 \%$.

13. SACHS, J. Lehrbuch. 1868.

14. Van Tieghem, Ph. Anatomie comparée de la fleur femelle et du fruit des Cycadées, des Coniféres, et des Gnetacées. Ann. Sci. Nat. V. 10: 269-304. pls. 13-16. 1869.

15. Strasburger, E. Die Befruchtung bei den Coniferen. 1869.

16. Von MoHL, Hugo. Morphologische Betrachtung der Blätter von Sciadopitys. Bot. Zeit. 29: 17-23. 1871.

17. Strasburger, E. Die Coniferen und Gnetaceen. 1872.

18. Eichler, A. W. Sind die Coniferen Gymnosperm oder nicht? Flora 54: 241-247, 260-272. 1873 ; and later papers.

19. Engelmann, G. Morphology of the Carpellary Scales of Coniferae. Am. Jour. Sci. III. 12: 469-470. 1876.

20. Stenzer, G. Beobachtungen an durchwachsenen Fichtenzapfen. Ein Beitrag zur Morphologie der Nadelhölzer. Nov. Act. Nat. Cur. 38: 289-350. pls. 12-15. 1876.

21. Strasburger, E. Die Befruchtung und Zelltheilung. Jen. Zeitsch. 2: 435-536. pls. 27-35. 18\%7.

22. Strasburger, E. Befruchtung und Zelltheilung. 1878.

23. Č́l一akovskí, L. Zur Gymnospermie der Coniferen. Flora 62 : 257-264, 272-283. 1879.

24. Strasburger, E. Die Angiospermen und die Gymnospermen. 1879.

25. Č́nakovskÝ, L. Zur Kritik der Ansichten von der Fruchtschuppe der Abietineen. Abhandl. d. königl. böhm. Gesell. d. Wiss. VI. 11: 1882.

26. Goroschankin, J. Zur Kenntniss der Corpuscula bei den Gymnospermen. Bot. Zeit. 41: 825-831. pl. $7 \mathrm{~A} .1883$.

Ueber den Befruchtung-Process bei Pinus Pumilio. 1883.

27. DE BARY, A. Comparative Anatomy of the Vegetative Organs of the Phanerogams and Ferns. English translation. 1884.

28. STrasburger, E. Neue Untersuchungen, etc. 1884.

29. Č́lakovský, L. Die Gymnospermen: eine morphologisch-phylogenetische Studie. Abhandl. d. königl. böhm. Gesell. d. Wiss. VIII. 4: 1890 .

30. BeLajefr, W. Zur Lehre von dem Pollenschlauche der Gymnospermen. Ber. d. deutsch. bot. Gesell. 9: 280-286. pl. 18. 1891.

31. Strasburger, E. Ueber das Verhalten des Pollens und die Befruchtungsvorgänge bei den Gymuospermen. Hist. Beitr. 4: 1-158. pls. 1-8. 1892. 
31a. Motrier, D. M. On the Archegonium and Apical Growth of the stem in Tsuga Canadensis and Pinus silvestris. Bot. Gaz. 17: 141-143. pl. 8. 1892.

32. BelajefF, W. Zur Lehre von dem Pollenschlauche der Gymnospermen (Zweite Mittheilung). Ber. d. deutsch. bot. Gesell. 11: 196-201. pl. 12.1893.

33. Dixon, H. N. Fertilization of Pinus silvestris. Ann. Bot. 8 : 2134. $p l s . ~ 3-5 . ~ 1894$.

34. Shaw, W. R. Contribution to the Life-history of Sequoia. Bot. Gaz. 21: 332-339. pl. 24. 1896.

35. Č́lakovsḱ், L. Nachtrag zu meiner Schrift über die Gymnospermen. Engler's Bot. Jahrb. 24: 202-231. 1898.

36. Coulter, J. M. Notes on the Fertilization and Embryogeny of Conifers. Bot. Gaz. 23: 40-43. pl. 6. 1897.

37. Blackman, V. H. On the Cytological Features of Fertilization and Related Phenomena in Pinus silvestris L. Phil. Trans. Roy. Soc. 190: 395-426. pls. 12-14. 1898.

38. Chamberlain, C. J. Winter Characters of certain Sporangia. Bot. Gaz. 25: 125-128. pl. 11. 1898.

39. Chamberlain, C. J. Oogenesis in Pinus Laricio. Bot. Gaz. 27: 268-280. pls 4-6. 1899.

40. JäGER, L. Beiträge zur Kenntniss der Endospermbildung und zur Embryologie von Taxus baccata. Flora 86: 241-288. pls. 15-19. 1899.

41. Wоусіскі, Z. On Fertilization in Coniferae (in Russian). pp. 1-57. pls. 2. 1899.

42. ARNold, W. Bull. Soc. Imp. Nat. Moscou. 329-341. pls. 2. 1899 (1900); see review in Jour. Roy. Micr. Soc. 1900: 428.

43. ARnoldr, W. Beiträge zur Morphologie der Gymnospermen. III. Embryogenie von Cephalotaxus Fortunei. Flora 87: 46-63. pls. 1-3. 1900.

44. ARNoldI, W. Beiträge zur Morphologie der Gymnospermen. IV. Was sind die "Keimbläschen " oder "Hofmeister's-Körperchen" in der Eizelle der Abietineen? Flora 87: 194-204. pls. 6-7. 1900 .

45. Coker, W. C. Observations on the Gametophyte and Embryo of Taxodium distichum. Johns Hopkins Univ. Circ. 19: 45-46. 1900.

46. GokBEL, K. Organography of Plants. English translation. 153155. 1900.

47. WorsdelL, W. C. The Structure of the Female "Flower" in Coniferae. Aun. Bot. 14: 39-82. 1900.

48. WorsDell, W. C. The Vascular Structure of the Orule of Cephalotaxus. Ann. Bot. 14: 317-318. 1900.

49. MURrill, W. A. The Development of the Archegonium and Fertilization in the Hemlock Spruce (Tsuga Canadensis). Ann. Bot. 14: 583-607. pls. 31-32. 1900. 


\section{CHAPTER IV}

\section{GNETALES}

Tris group includes three genera which differ remarkably in habit and habitat. Certain angiospermous characters which they display have suggested that they may have given rise to Angiosperms, but such a theory seems to have been abandoned by most morphologists. The two characters of the group which have been regarded as distinguishing it from other Gymnosperms are (1) the occurrence of "true vessels" in the secondary wood, and (2) the presence of a "perianth." A mere statement of these characters is apt to lead to an exaggerated conception concerning their importance. The "true vessels" are usually intermediate in character between the tracheids of ordinary Gymnosperms and the tracheae of Angiosperms, and are as easily associated with the former as with the latter. The "perianth" is a doubtful structure, and is probably no more the equivalent of the perianth of Angiosperms than are the bracts closely related to the stamens and ovules in other Gymnosperms.

In addition to the two distinguishing characters given above, the group has the four following characters in common, but not peculiar to it: (1) opposite leaves (a crelic character also displayed by the Cupresseae); (2) dicotyledonous embryos (found also in Cycads and in several groups of Conifers); (3) cauline ovules (true also of Taxaceae and perhaps of all Conifers); and (4) no resin ducts (true also of Tarus). To these characters perhaps should be added the remarkable prolongation of the integument of the ovule to form a long tubular micropyle.

The genera are Ephedra, with about thirty species, from the arid regions of both hemispheres; the monotypic Tumboa (Welwitschia), from the extremely arid regions of western 
South Africa; and Gnetum, with about fifteen species, from the tropics of both hemispheres.

The important morphological literature of the group may be outlined historically as follows: In 1863 Hooker ${ }^{1}$ published an account of Tumboa in an elaborate memoir, which is probably more generally accessible in Eichler's ${ }^{2}$ very full review. In 1872 Strasburger ${ }^{3}$ published the first adequate account of the more recondite morphological features of the group. In 1877 Beccari ${ }^{4}$ gave an account of the ovulate flowers of Gnetum, and discussed the nature of the floral structures; while in 1879 Strasburger ${ }^{5}$ extended and co-ordinated his previous observations. It is chiefly from the two publications of Strasburger that the current accounts of text-books have been derived. In 1881 Bower ${ }^{6,7}$ published accounts of the embryo of Tumboa; and in 1882 the same author ${ }^{8}$ performed a similar service in the case of Gnetum. These two accounts still remain practically the only source of information concerning the embryos of Tumboa and Gnetum. In 1892 Strasburger $^{\circ}$ again discussed the Gnetales, and in the same year Karsten ${ }^{10}$ published a preliminary paper upon the genus Gnetum. In 1893 Karsten ${ }^{11,12}$ published two additional papers, in which he modified and extended his previous conclusions. In 1894 and 1895 Jaceard ${ }^{13,14}$ published accounts of Ephedra Helvetica, which assisted materially to an understanding of the group. The most recent contribution is that of Lotsy, ${ }^{15}$ who has given a very important account of the female, gametophyte and fertilization in Gnetum Gnemon. $\mathrm{He}$ has also done great service in bringing together the essential features of the scattered literature, and in contrasting the results of different investigators.

In the following account of Gnetales these various authors have been laid under contribution, as we have had no opportunity to examine any properly fixed material.

\section{THE VEGETATIVE ORGANS}

The species of Ephedra are low straggling shrubs, with longjointed and fluted green stems, and opposite scalelike leaves connate into a two-toothed sheath. True foliage leaves are generally lacking, the work of photosynthesis being assumed by the stem, as in the case of the Equisetales, whose stems are very suggestive of Ephedra (Fig. 83). 
Tumboa is a remarkable monotypic genus. As described and figured by Hooker, ${ }^{1}$ the body has the shape of a gigantic radish, which rises little above the surface of the ground, and whose crown is sometimes 3.5 to 4.5 meters in circumference.

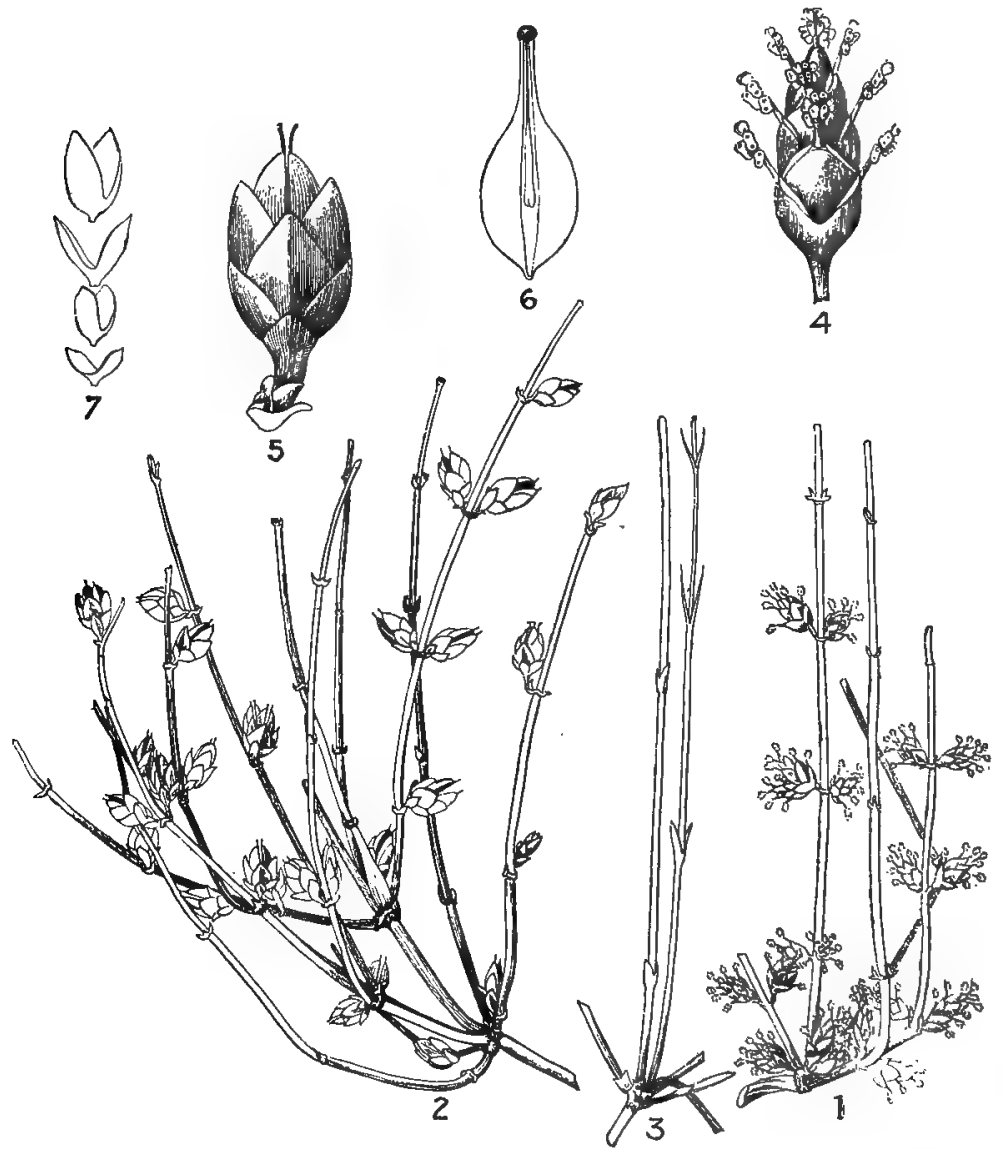

FIG. 83.-Ephedra antisyphilitica : 1 , staminate branches ; 8 , ovulate branches ; $s$, sterile brauches; 4, staminate strobilus; 5 , ovulate strobilus; 6 , longitudinal section of seed; 7 , bracts of the ovulate strobilus.-After W ATson.

The broad top is more or less concave and somewhat two-lobed, and from the deep horizontal groove which separates the crown from the body two enormously long parallel-veined leaves arise, which extend upon the ground sometimes for 3 to 3.5 meters, 
and become split into numerous ribbons (Fig. 84). This single pair of opposite leares succeeds the cotyledons, and is the only pair of foliage leaves produced, growing continually at the base,

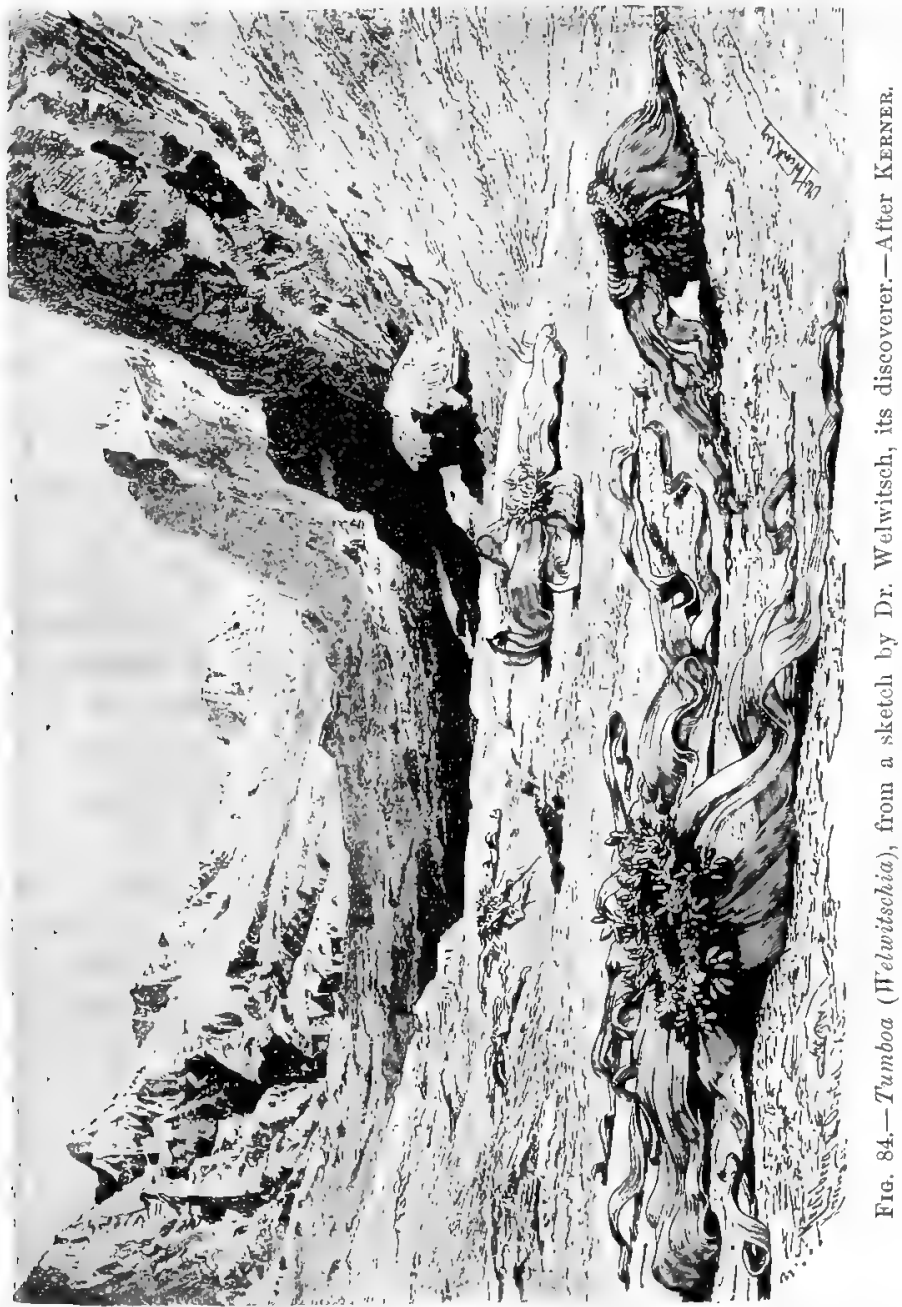

where it is protected hy the groove. These leaves last through the lifetime of the plant, which is sairl to reach more than a hundred years.

The species of Ginotum are cither small trees or wooty climb- 
ers, being among the prominent lianas of tropical forests (Fig. 85). The foliage is leathery in texture, and is very suggestive of Dicotyledons, the well-developed opposite leaves being lanceolate to ovate in outline and pinnately net-veined (Fig. 88).

\section{THE STEM}

Ephedra.-The characteristic long-jointed and fluted green stems have been spoken of above. In the stem tip the dermatogen and periblem eap the plerome cylinder with distinct layers, each layer having its own initials, or the three embryonic regions merge in a common group of initials. It is of interest to note that both of these conditions have been found in a single species (E. campylopoda). There are no cauline bundles, as in Tumboa and Gnetum, and no secondary cambium. The primary cambium develops a certain amount of secondary tissue, but the increase in diameter is never striking. The tracheary vessels of the secondary wood, which distinguish Gnetales from other Gymnosperms, are found in Ephedra at the inner part of the secondary xylem cylinder, and consist of broad vessels associated with ordinary gymnospermous tracheids. These vessels are interrupted, moreover, by oblique walls, and display bordered pits as well as simple pits. In every way they seem to be modified gymnospermous tracheids. A peculiar feature of the genus is the diaphragmlike plate of cells which occurs at the base of each internode, rendering the stem easily separable at the nodes. The stomata occur upon the fluted stem in rows, as in Equisetum. and are sunken in urn-shaped depressions formed by mounds of cuticle.

Tumboa.-The anatomy of the stem is somewhat confusing on account of the extremely shortened axis. In the region where the short crown and large tap root merge there is a broad stratum of collateral bundles, which De Bary recognizes as two layers very close together, and calls the "layer of the leaf trace." The upper layer connects with the numerous veins of the leares, and the lower layer is associated with the system of vessels in the tap root. The primary cambium is short-lived, and a series of irregularly concentric bundles suggests a succession of seeondary cortical cambiums. The resemblance to Cycads is further marked by the occurrence of cauline bundles, not only in the cortex but also in the pith. It is reported also that trachids 


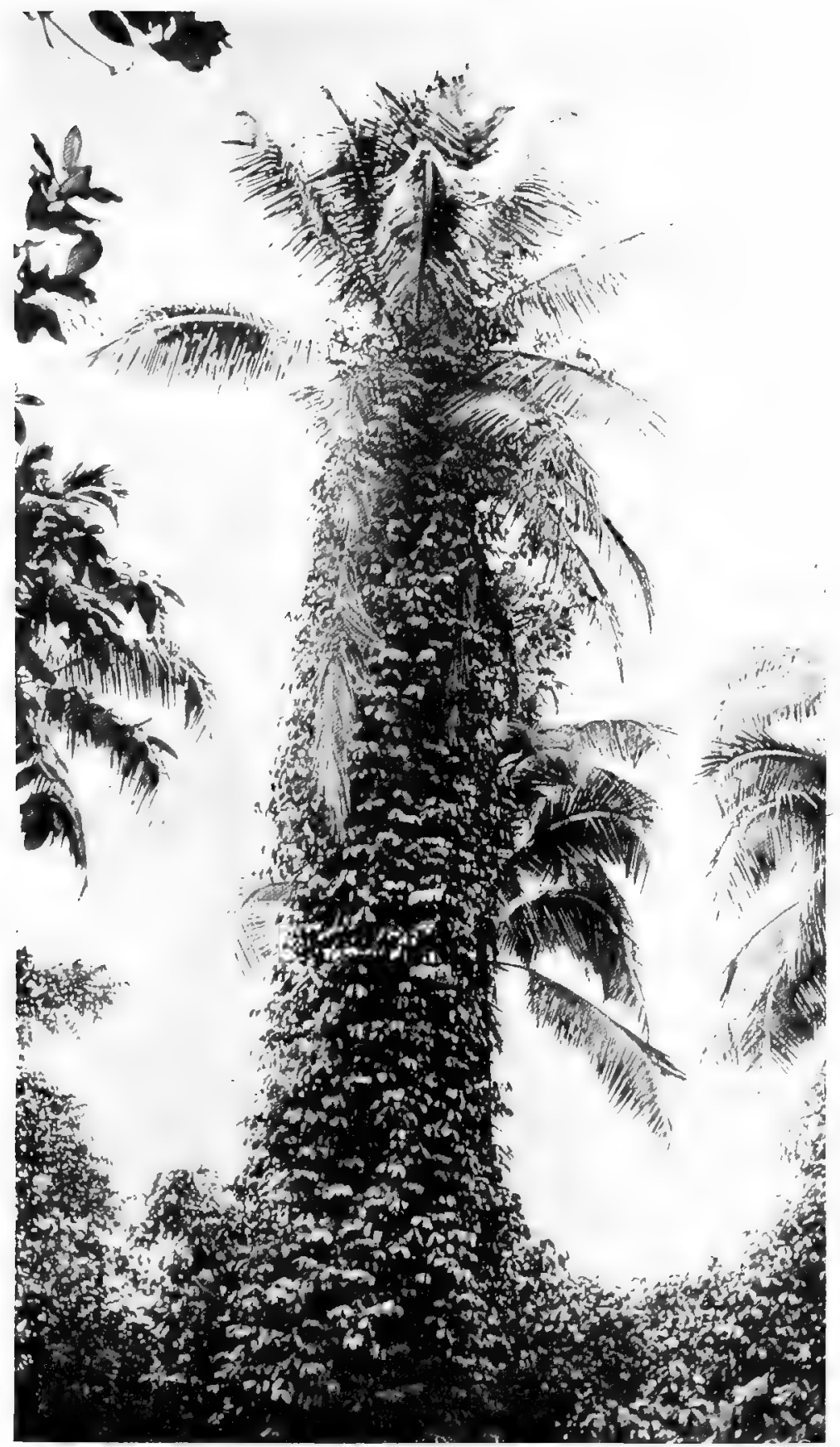

FIG. 85.-Gnetum ovalifolium, climbing on Cocos nucifera.-After Karsten. 
with bordered pits are entirely lacking, simple pitted and spiral vessels replacing them. In connection with the vascular bundles there is a conspicuous development of fibrous sclerenchyma. In the stem as a whole parenchymatous tissue largely predominates, and forms a conspicuous water-reservoir system.

Perhaps the most remarkable anatomical feature is the occurrence of the so-called "spicular" cells, found in large numbers and scattered throughout all organs. They are very large, fusiform or branched, straight or variously curved, with greatly thickened walls, in the outer layers of which many finely formed crystals of calcium oxalate are imbedded close together.

Gnetum.-As in Tumboa, the primary cambium is shortlived, and successive cortical cambium zones organize concentric series of cauline bundles. As in Ephedra, the xylem contains vessels of the true tracheary type associated with tracheids of the Gymnosperm type.

\section{THI LEAF}

Ephedra.-The opposite leaves of Ephedra are reduced to scales, which coalesce to form at each node a two-toothed sheath. The occurrence of true foliage leaves seems to be extremely rare.

Tumboa.-In the single pair of long-lived parallel-veined leaves the stomata are in rows and deeply sunken. The chlorophyll-bearing tissue beneath the epidermis ensheaths a prominent central tissue which is colorless or nearly so, and constitutes a conspicuous water reservoir. The colorles middle tissue is traversed by the very numerous and strong parallel bundles, which are connected by transverse branches. These branches sometimes end freely in the mesophrll, or send out branchlets which end blindly. While the general syrstem of venation is of the monocotyledonous type, the blind ending of certain branches is a dicotyledonous feature.

Gnetum.-The leares of Gnetum seem to differ in no essential feature from such leaves of Dicotyledons as are leathery in texture, having a typical reticulate bundle system of the pinnate variety.

\section{THE ROOT}

The very meager accounts of the roots of Gnetales have reference only to species of Ephedra. From these it appears that the group possesses the same peculiarities shown by the other 
Gymnosperms. The root cap is derived in the same way from the outer exfoliating layers of the periblem, and the primary vascular eylinder is diarch.

\section{THE SPORE-PRODUCING MEMBERS}

\section{THE MICROSPORANGIUM}

So far as we can discover, there is no recorded information as to the development of the microsporangium in Gnetales, but presumably it follows the general sequence common to Gymnosperms and Angiosperms. The following account, therefore, can deal only with the gross structure of the so-called staminate flowers.

Ephedra.-The flowers are monosporangiate, and are borne in the axils of bracts in a spicate inflorescence. The staminate

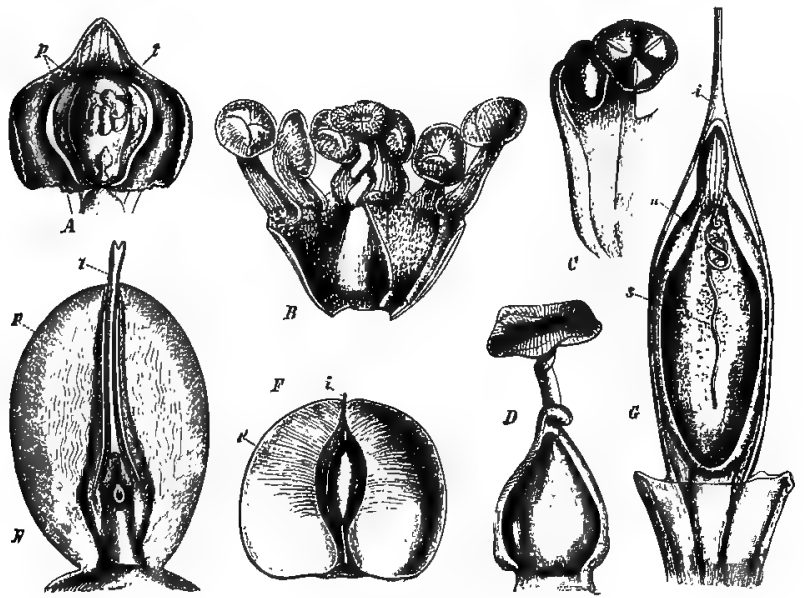

Fis. 86.-Tumboa: $A$, young staminate flower; $B$, older staminate flower, with the sterile ovule in the center: $C$, two stamens; $D$, the sterile ovule; $E$, the ovulate flower, showing tubular micropyle $(i)$ and winglike expansions of the "perianth"; $F$, the same after fertilization; $G$, longitudinal section of a ripe seed, showing conspicuous suspensor (8).-After Strasborger, the figure being-taken from ENGLER and Pran'TL's Nat. Pflanzenfam.

flower consists of two more or less connate scales ("perianth") investing a projecting axis, which bears two or more sporangia. The sporangia appear to be cauline, the sporangiferous axis remaining simple and bearing two sporangia, or branching somewhat above and bearing several sporangia (Fig. 83). 
Tumboa.-While the flowers are functionally monosporangiate, there is evidence of their derivation from a bisporan-

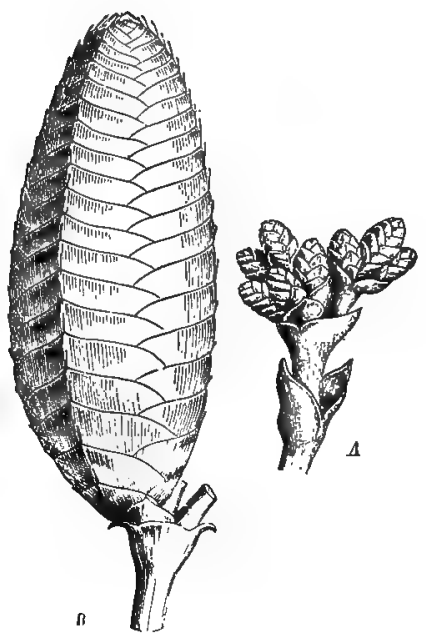

Fig. 87.-Tumboa: $A$, staminate strobilus : $B$, ovulate strobilus; both two thirds natural size.- $A$ from the Bot. Mag., $B$ after Le Maout and DECAISNE; the whole figure from Engler and Pranth's Nat. Pflauzenfam. giate condition. They are borne in the axils of prominent opposite bracts which form conelike strobili. These strobili are produced upon branching axes, which arise from the crown above the foliage leaves, or rarely beneath them. The staminate flower consists of two decussate pairs of free bracts, forming the so-called perianth, within which there is a whorl of six (rarely five or four) monadelphous stamens, each of which is capped by a group of three sporangia. In the center is a single sterile ovule, whose projecting micropyle is spirally coiled and has a flaring expansion at the tip (Figs. 86, 87).* The whole structure is puzzling and anomalous among Gymnosperms, for it seems to indicate derivation from a perfect flower. The microsporangia also seem to be distinctly foliar in origin.

Gnetum.-The flowers are monosporangiate and mostly dioecious, the inflorescence being in the form of spikes of connate bracts with numerous flowers in their axils. The staminate flowers resemble those of E phedra, consisting of two coherent bracts investing a short axis which bears two sporangia. Such evidence as we have indicates that these sporangia are cauline (Fig. 88).

THE MEGASPORANGIUTI

Ephedra.-In the spicate inflorescence one or more ovulate. flowers occur in the axil of each bract. Each florrer consists of two more or less connate scales which invest a solitary cauline

* Excellent illustrations of the staminate and ovulate strobili may be found in Grideners' Chronicle III. $24: 63.1898$. 
ovule whose integument is produced into a very long tubular projecting micropyle. In fruit the bracts are much modified, becoming red and succulent, or much enlarged and chaffy, and the "perianth" persists and becomes lignified (Fig. 83).

The development of the megasporangium, as given by Strasburger $^{3}$ for $E$. campyloda, indicates the usual sequence of events. The archesporium consists of a group of hypodermal cells, which by periclinal division cut off wall cells. The extensive periclinal division of the wall cells organizes them into very regular longitudinal rows (Fig. $89, A$ ), and places the primary sporogenous cells deep within the nucellus. Whether the primary sporogenous cells divide or pass directly into mother cells is not clear, but in any event the mother cells form a deepseated group variable in number or even reduced to one.

Tumboa.-In the conelike strobilus the ovulate flowers are axillary, and contain a single ovule, with no trace of stamens.

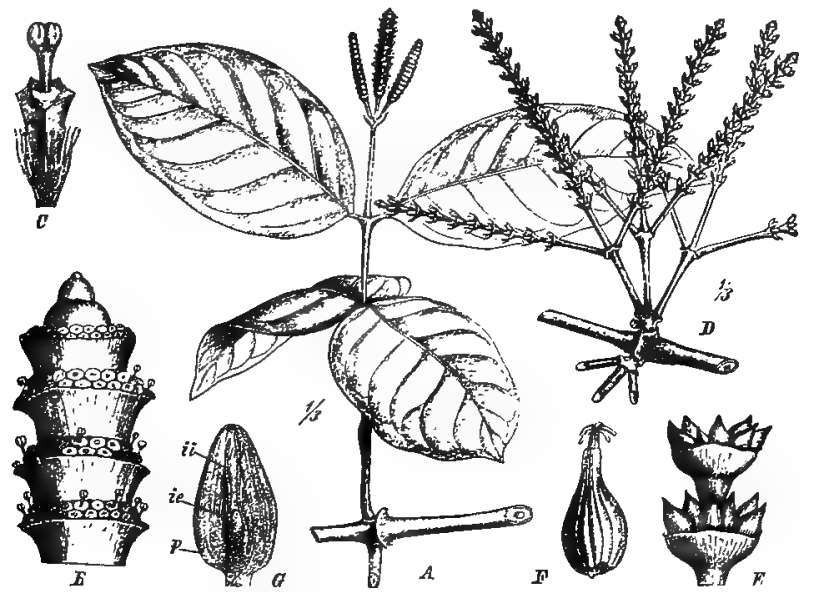

FIG. 88.-Gnetum: $A$, branch with leaves and staminate strobili; $B$, upper portion of a staminate strobilus; $C$, a staminate flower; $D$, a branch with ovulate strobili; $E$, upper portion of an ovulate strobilus; $F$, an ovulate flower; $G$, longitudinal section of an ovulate flower, showing the three envelopes $(i i, i e, p) ; A-E, G$ netum latifolia; $F-G, G$ netum sp. ? $-A-E$ after Blume, $F$ and $G$ after Strabetraer: whole figure from EngLer and PrantL's Nat. Ptanzenfam.

The perianth consists of a single pair of completely united bracts, which close over the ovule like an outer integument and become much flattened laterally, forming two opposite winglike expansions. The integument directly investing the ovule forms 
the usual long projecting tubular micropyle, which is neither spirally coiled nor expanded at the tip as in the sterile ovule of the staminate flower. In fruit the enlarged bracts become bright scarlet, and the seed is winged by the expanded perianth (Figs. 86, 87).

Very little is known concerning the details of the development of the megasporangium beyond the fact that a group of mother cells is deep-seated beneath long rows of wall cells, as in other Gymnosperms. The rows of wall cells are organized into a somewhat persistent nucellar cap or beak, recalling the Cycadales and Ginkgoales. There is no evidence that the beak develops a pollen chamber, but it is said to become riddled with passageways which are utilized by the ascending archegonial tubes and descending pollen tubes.

Gnetum.-According to Lotsy, ${ }^{15}$ in $G$. Gnemon the very young ovulate spike consists of a series of close-set cups, each cup representing coalescent bracts. Later the cups are well separated by the lengthening of the internodes, and within each a prominent ringlike cushion appears. From the lower portion of the cushion abundant yellowish paraphysislike hairs are developed, while from the top of the cushion the more or less numerous ovulate flowers arise, each flower apparently representing an axillary bud (Figs. $88, E$, and $91, A$ ). The solitary ovule is organized directly from the tip of the bud axis, and hence is cauline, while about it there arise in acropetal succession three envelops, the homologies of which have given rise to considerable discussion (Fig. 91, $G$ ). The outermost envelop is green and fleshy, resembling the perianth in Ephedra; the middle one is more delicate, not green, and does not rise so high as the outer one; while the innermost is the long-necked structure called an integument in Ephedra and Tumboa. The tip of the micropylar tube is more or less lacerate, and the lobes spread during pollination (Fig. 88, $F$ ).

Strasburger ${ }^{9}$ discovered that there are two kinds of ovulate flowers, those of the ovulate spikes, described above, and those found in the staminate spikes. The latter differ in having but two envelops about the ovule, the middle one of the complete flower being absent. These incomplete flower's do not function, but sometimes they develop far enough to contain embryo sacs. In the very/ rare cases when an ovulate flower on a staminate 
spike functions, Lotsy ${ }^{15}$ observed that it possesses the three envelops of the complete ovulate flowers. Karsten ${ }^{10,11,12}$ found that the middle envelop appears during the development of the incomplete ovulate flowers, but gradually disappears.

Strasburger ${ }^{9}$ regards all three envelops as integuments, the middle and innermost corresponding to the inner envelop in Ephedra. Beccari ${ }^{4}$ first described the organogeny of the flower, discovering that the three envelops appear in acropetal succession. This seemed to militate against the theory of ovular integuments, which appear in basipetal succession. Beccari's interpretation, however, seems somewhat fanciful, since he regards the middle envelop as the homologue of the staminate cycle in Tumboa, the outermost envelop being a perianth. Lotsy regards the two outer envelops as two whorls of bracts, which he calls the perianth, and claims that there is only a single integument. He lays stress upon the fact that in the two outer envelops there is vascular tissue, claiming that this indicates their foliar nature.

If Čelakorský's general claim be accepted, that there are two integuments in all Gymnosperms, the so-called perianth of Gnetales becomes an outer integument, and the middle envelop of the ovulate flowers of Gnetum may well be only an outer layer of the inner integument, as Strasburger has suggested. In any event, there seems to be no question as to the tegumental nature of the innermost envelop, and the acropetal succession of the envelops would indicate that the one or two outer ones are modified bracts. It must be remembered that this does not necessarily militate against Čelakorský's view, since he regards integuments as of foliar origin.

The development of the megasporangium has been described in detail by Strasburger ${ }^{3}$ for Gnetum Gnemon, and coincides with the general sequence in Gymnosperms. The archesporium consists of a group of hypodermal cells which cut off wall cells by periclinal division. By repeated periclinal divisions the wall cells form the usual thick mass of sterile tissue above the sporogenous region (Fig. 91, $F^{\prime}$ ). Before pollination the cells at the tip of the nucellus disorganize, an irregular pollen chamber being the result, much as in Pinus. The several primary sporogenous cells divide more or less and organize the deep-seated group of mother cells. 


\section{THE GAMETOPHYTES}

THE FEMALE GAMETOPHYTE

While the female gametophyte conforms in a general way to the Gymnosperm type, there are certain remarkable deviations in Tumboa and Gnetum which are suggestive of a possible method of derivation of the embryo sac structures of Angiosperms.
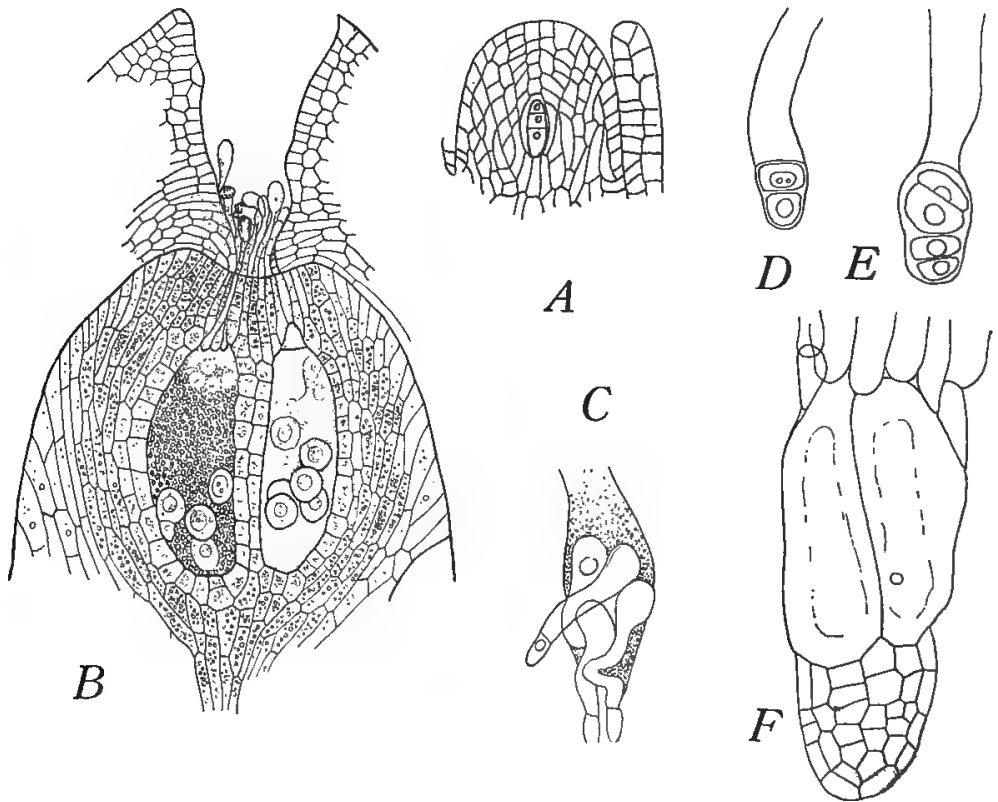

Fia. 89.-Ephedra: $A$, young ovule showing a row of three potential megaspores; $B$, upper part of nucellus after fertilization, showing the free cells of the proembryo within.the two oospores, $\times 64 ; C$, suspensors developing from the free cells, passing from the oospore into the endosperm, and each bearing at tip an embryonal cell, $\times 64 ; D-F$, later stages in the development of the embryo, $\times 154 ; A, E$. campylopoda; $B-F, E$. altissima.-After Strasburger.

Ephedia.-According to Strasburger's account ${ }^{3}$ for $E$. campylopoda, the mother cells organize a row of three potential megaspores, the lowest of which is the fertile one (Fig. 89, A). In case several fertile megaspores begin to enlarge, one finally dominates and develops the gametophrte.

The details of the germination of the megaspore are lacking, but Strasburger's outline is the usual one among Grimnosperms. 
The nucleus of the spore begins free nuclear division, the nuclei become imbedded in a parietal layer of cytoplasm which surrounds a great central vacuole, and free nuclear division continues until numerous nuclei appear within the enlarging embryo sac. Walls next appear, and a layer of parietal tissue develops, which by continued cell division gradually fills the sac with a compact tissue, as in Conifers. The archegonia have unusually long necks, and apparently a remarkably persistent ventral canal cell.

It is evident that in Ephedra there is the least departure from what may be called the Gymnosperm type of female gametophyte, and presumably Ephedra may be regarded as the most primitive of the Gnetales.

Tumboa.-This genus needs reinvestigation from the standpoint of modern technique and modern morphology, for the facts recorded concerning it are somewhat vague and may be misleading. Nothing is known of the development of the solitary functional megaspore further than that it lies at first deep within the nucellus beneath long rows of wall cells. As this is true of Gymnosperms in general, it may be assumed that the history up to this point is the same.

Apparently the germination of the megaspore also proceeds in the usual way, with free nuclear division, imbedding of the free nuclei in a parietal layer of cytoplasm, appearance of walls, and gradual centripetal filling of the embryo sac. It is evident, however, that the tissue in the micropylar end of the embryo sac is less compacted than that in the antipodal end. In any event, the archegonium initials upon the micropylar surface of the gametophyte behave in an exceedingly peculiar and independent fashion. It is reported that there are from twenty to sixty of these initials, and that they proceed no further in the development of archegonia than to assume the appearance of ordinary archegonium initials, an egg being organized directly within each of them without any division. Just why the development of archegonia should stop with the selection and enlargement of initial cells is hard to understand except upon the hypothesis that they are practically free cells. Each of these cells, representing a greatly reduced archegonium, contains an egg which is ready for fertilization. There is suggested an intermediate condition between Ephedra, with its complete arche- 
gonia, and Gnetum, with its free eggs. No less remarkable than the structure of the archegonium, if such it may be called, is its behavior in connection with fertilization. It is reported that each archegonial cell develops a long tubular process which penetrates into the sterile tissue of the nucellus, and passing along one of the numerous passageways of the beak meets the approaching pollen tube (Fig. 90). It is needless to comment

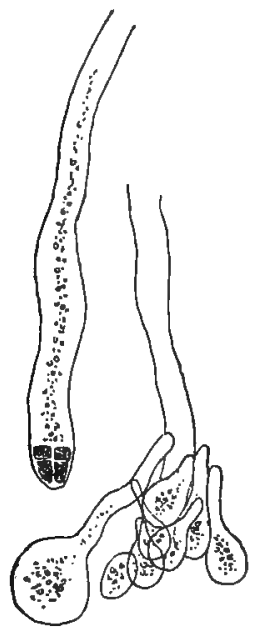

Fra. 90.-Tumboa: the figure to the right represents a group of archegonium initials sending out tubular prolongations into the nucellus to meet the descending pollen tubes; the figure to the left and above represents the suspensorlike elongation of the oospore, bearing at its tip embryonal cells.-After StrasBURGER. upon this peculiar structure and behavior until the details are more fully known.

Gnetum. - In Strasburger's account $^{3}$ of $G$. Gnemon it is not apparent whether or not the mother cells develop a row of potential megaspores. In any event, several megaspores begin to enlarge, and free nuclear division may occur in a number of them before one finally dominates the rest.

The germination of the megaspore has been given in detail by Lotsy, ${ }^{15}$ and his account for Gnetum Gnemon is as follows: The nucleus of the megaspore begins the usual series of free nuclear divisions, but since there is such great diversity between the micropylar and antipodal contents of the embryo sac, Lotsy raises the question whether the polarity of the sac may not have been established by the first division of the megaspore nucleus. Unfortunately, the persistent absence of spindles in his material prevented him from answering the question. Soon the free nuclei become imbedded in a thin parietal layer of cytoplasm surrounding a great central vacuole (Fig. 91, $H$ ). In this condition a constriction develops in the sac somewhat below the middle of its long axis, which persists until the final growth of the sac obliterates it. This constriction divides the sac into two very distinct chambers. The smaller antipodal chamber speedily fills with a compact tissue, in the way usual for the whole embryo 
sac in other Gymnosperms, while the micropylar chamber still contains only free nuclei (Fig. 91, $I$ ).

It is in this stage that fertilization occurs, for the free nuclei, or presumably free cells, of the micropylar chamber are all apparently potential eggs. Archegonia, therefore, are no more developed than in Angiosperms. If fertilization does not take place, the whole sac becomes filled with tissue. After fertilization the tissue of the antipodal chamber renews its growth, finally destroys the nucellar tissue, and encroaches upon the rest of the sac, a small cavity at the micropylar end representing the micropylar chamber. Lotsy also states that certain of the free nuclei which are not fertilized organize definite cells, resernbling free endosperm cells of Angiosperms. The same writer also calls attention to the fact that where the tissue of the antipodal chamber projects in conical fashion into the constriction certain structures resembling rudimentary archegonia appear.

The species of Gnelum investigated by Karsten ${ }^{10,11,12}$ show still further reduction of the female gametophyte than that exhibited by $G$. Gnemon. In these the whole sac behaves as does the micropylar chamber in G. Gnemon, so that endosperm tissue is not developed until after fertilization. It would seem, therefore, that $G$. Gnemon represents a condition of the gametophyte intermediate between its structure in Tumboa and the species of Gnetum investigated by Karsten.

'The strong polarity of the sac, the occurrence of naked eggs, the large or entire development of endosperm tissue after fertilization, are all features suggestive of the Angiosperm condition. Especially striking in the comparison with the Angiosperm embryo sac is the occurrence of free cells at the micropylar end of the sac, and of a compact tissue at the antipodal end.

\section{THE MALE GAMETOPHYTE}

The development of the male gametophyte in Gnetales is practically unknown. In Strasburger's account ${ }^{3}$ of Ephedra campylopoda it is stated that in the germination of the microspore three small cells are successively cut off, the first disorganizing, the second persisting, and the third presumably representing the primary spermatogenous or generative cell. This is an ordinary Gymnosperm outline, and the persistence of the second vegetative cell recalls Ginkgo. 

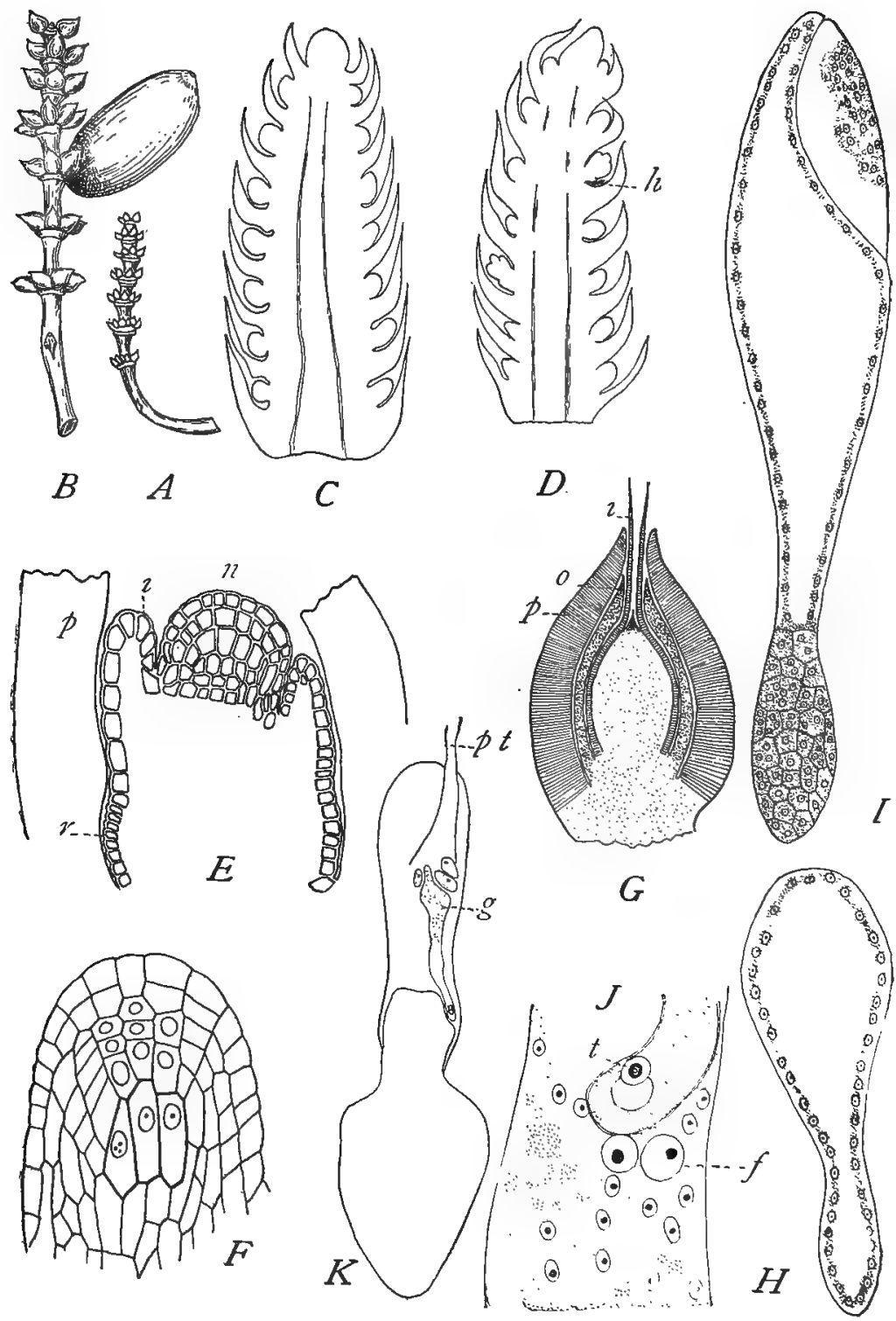

Fig. 91.-Gnetum Gnemon: $A$, ovulato strobilus: $B$, strobilus upon which only one seed has matured; $C$, longitudinal section of a young ovulate strobilus, $\times 24 ; D$, later stage, showing orules and paraphysial hairs $(h), \times 45 ; E$, longitudinal section of an immature ovulate flower, showing " perianth" $(p)$, inner integument (i), rudimentary outer integument $(r)$, and nucellus $(n) ; F$, nucellus showing three mother 
In Gnetum our only knowledge of the male gametophyte comes from the work of Lotsy ${ }^{15}$ upon G. Gnemon, in which the pollen tube just before fertilization was observed to contain the tube nucleus and two male cells of the ordinary Conifer type. Concerning the male gametophyte of Tumboa the only available information is contained in a few figures by Strasburger. ${ }^{9}$ The pollen grain is rather narrowly oblong in section, and on one of the broad sides of the section a small lenticular cell is shown, undoubtedly representing a vegetative cell. Whether there is only a single persistent cell of this kind, as in Cycads, or whether it is but one of two cells, as in Ginkgo and Conifers, is not apparent. The figures also show the division of the nucleus of the antheridium initial into tube nucleus and generative nucleus. Such eridence as is available indicates that the male gametophyte conforms to the type observed among other living groups of Gymnosperms.

\section{FERTILIZATION}

We have no information concerning the fertilization of Ephedra. The anomalous behavior of Tumboa has already been referred to, in which the wall of the archegonial initial develops a tubular process that penetrates the nucellus, meets a descending pollen tube, and receives its discharge. The advance of archegonial tubes and pollen tubes is expedited by the numerous passageways which riddle the caplike apex of the nucellus. The egg remains in the bulbous basal portion of the archegonial initial, and is fertilized there.

The fertilization of Gnetum Gnemon is given in considerable detail by Lotsy. ${ }^{15}$ One or more pollen tubes, each containing a tube nucleus and two male cells, penetrate into the micropylar chamber of the embryo sac, either at its apex or at the side. The tip of the tube within the sac usually becomes much distended, and discharges both male cells through a ter-

cells; $G$, longitudinal section of a mature ovulate flower, showing the "perianth" $(p)$, outer integument $(0)$, and inner integument $(i), \times 33 ; H$, embryo sac with free nuclei in a parietal layer, and showing the beginning of the constriction which results in the antipodal and micropylar chambers; $I$, cell fornation in the antipodal chamber, another sac which is being pushed aside is shown at the right above, $\times 50 ; \mathrm{J}$, upper portion of sac soon after fertilization, showing a pollen tube with its nucleus $(t)$, oospores $(f)$, and unfertilized eggs, $\times 340 ; K$, embryo sac showing the suspensorlike development of the oospore $(g)$ advancing toward the antipodal endosperm, $\times 50$.-All from Lotsy excepting $F$, which is after STrasburger. 
minal pore. Each male cell fuses with a free egg, and as many oospores are formed as there are male cells discharged into the sac-that is, twice as many as there are discharging pollen tubes (Fig. 91, J). The oospore was observed to organize at once about the fusion nucleus a comparatively dense layer of cytoplasm, and soon a cell membrane appeared. The oospores may remain free, or they may become attached to the tips of the pollen tubes which belong to them.

\section{THE EMBRYO}

Ephedra.-An account of the development of the embryo of Ephedra altissima is given by Strasburger. ${ }^{3}$ Germination begins with free nuclear division, and two to eight free cells, sometimes more, are organized within the oospore (Fig. 89, B). These free cells do not organize any definite tissue as in Conifers. As a consequence, each cell continues to act independently, elongating to form a suspensorlike tube, which emerges from the oospore and penetrates the endosperm (Fig. 89, C). The more or less numerous tubes, emerging in various directions, are bulbous within the oospore, where they are in contact with its nutritive supply, and at the free tip cut off a single cell, from which the embryo proper is developed. The embryonal cell divides transversely, which is followed by other transverse divisions, forming a short filament (Fig. 89, $D, E$ ). Longitudinal divisions succeed, and later periclinal divisions (Fig. 89, $F$ ). No details of the organization of the growing points are recorded.

Tumboa.-After fertilization, it is reported that the archegonium initial elongates and penetrates the endosperm as a suspensor, which is a long, much-coiled, and very persistent structure, and carries the egg in its tip. It is probably the fact that the so-called archegonial suspensor is a tube dercloped by the oospore, just as in the free oospores of Gnetum, and that the so-called egg in its tip is the mucleus of the oospore. In any event, the embryonal cell appears as a small cell cut off at the tip of the suspensorlike tube (Fig. 90), and gives rise not only to the embryo proper but also to numerous embryonal tubes (Fig. 92).

According to Bower's account ${ }^{6,7}$ of the embryo, the first division of the embryonal cell is longitudinal. Then a trans- 
verse division and other longitudinal divisions follow, until a pyramidal mass of cells is organized at the end of the suspensor. From the basal cells of this mass the embryonal tubes develop (Fig. 92). No details of the organization of the various growing points are given, but the completed embryo consists of a welldeveloped root and a long hypocotyl, between which there is organized a very conspicuous footlike process, that remains in the seed during its germination. Two cotyledons are developed, as in all Gnetales.

Gnetum.-According to Lotsy, ${ }^{15}$ the free oospores develop long tubes, which advance toward the mass of antipodal endosperm and penetrate into it deeply, sometimes branching. During this advance the nucleus keeps in the tip of the tube (Fig. 91, $K$ ). There is every reason to suppose that this is a repetition of the behavior noted in Tumboa. It is after this penetration of the antipodal region that the endosperm renews its growth and finally encroaches upon the whole nucelIus. It is in this condition, with the tubular oospore, containing the nucleus in its tip, imbedded in the antipodal endosperm, that the seed drops. Iotsy reports that occasionally the tubes are not directed toward the antipodal region, but may pass out of the micropylar chamber into the nucellus, or may grow directly away from the antipodal region. In either of these cases there is no further development.

The further development of the embryo

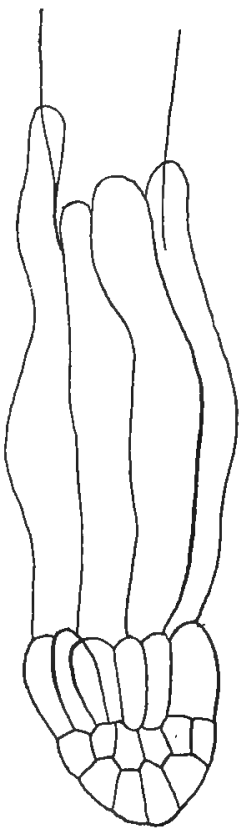

FIG. 92.-Tumboa: a young embryo consisting of a pyramidal group of cells, the basal ones giving rise to embryonal tubes. - After. STRAgBURGER. of Gnetum Gnemon has been studied by Bower. ${ }^{8}$ At the tip of the oosporic tube an embryonal cell is cut off. This cell divides longitudinally and transversely, until a small group is organized (Fig. 93,A), the basal cells of which give rise to embryonal tubes, just as in Tumboa. The mature embryo also resembles that of Tumboa in its two cotyledons, and prominent hypocotyl and root between which a conspicuous foot is developed (Fig. 93, $B$ ). 
In the germination of the oospore, and in the structure of the female gametophyte, there is evidence that Tumboa and

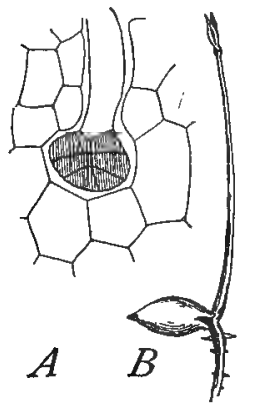

Fie. 93.-Gnetum Gnemon: $A$, a young embryo at the tip of a suspensor and imbedded in endosperm; $B$, a germinating seed, the root and stem tips having escaped, and the foot remaining within the seed coat.-After Bower. Gnetum are allied forms, the latter having proceeded further in the reduction of its gametophyte preceding fertilization. It is also evident that Ephedra must be associated with them as the least modified form, its gametophyte retaining the character of those in other Gymnosperms, while the germination of its oospore is fairly transitional between Conifers on the one hand and Tumboa and Gnetum on the other. There is free nuclear division in the oospore, as in Conifers, but the cells organized in connection with them remain independent and behare as do the oospores of Tumboa and Gnetum. It should be remarked, also, that the number of free cells developed within the oospore of $E$ phedra may be reduced to two, and that any further reduction would probably result in causing the whole oospore to behare as do these of Tumboa and Gnetum. If Ephedra be associated with Tumboa and Gnetum, as seems reasonable, there is equally weighty evidence for regarding it as the group of Gnetales most nearly related to the Conifers, for its female gametophyte and the early stages in the germination of its oospore are identical with those in Conifers.

\section{LITERATURE CITED}

1. Hooker, J. D. On Welwitschia, a new genus of Gnetaceae. Trans. Linn. Soc. London 24: 1-48, pls. 1-14. 1863.

2. EIOHLer, A. W. Ueber Welwitschia mirabilis, ete. Flora 47: 459-464, 473-479, 4\$9-496, 508-510, 513-520. 186i3.

3. Strasburger, E. Die Coniferen und die Gnetaceen. $187 \%$.

4. BECCARI, O. Della organogenia dei fiori feminei del Gnetum Gnemon L. Nuovo Giorn. Bot. Ital. 7: 91-99. 1877.

5. Strasburger, E. Die Angiospermen und die Gymnospermen. 1879.

6. Bower, F. O. On the Germination and Histology of the Seedlings of Weluitschia mirabilis. Quart. Jour. Micr. Sei. 21: 15-30. pls. 8 -4. 1881. 
7. Bower, F. O. On the Further Development of Welwitschia mirabilis. Quart. Jour. Micr. Sci. 21 : 571-594. pls. 20283. 1881.

8. BowER, F. O. The Germination and Embryology of Gnetum Gnemon. Quart. Jour. Micr. Sci. 22: 278-298. pl. 25. 1882.

9. Strasburger, E. Ueber das Verhalten des Pollens und die Befruchtungsvorgänge bei den Gymnospermen. Hist. Beitr. 4: 1-158. pls. 1-3. 1892.

10. Karsten, H. Beiträge zur Entwickelungsgeschichte der Gattung Gnetum. Bot. Zeit. 50: 205-215, 221-231, 237-246. pls. 5-6. 1892.

11. Karsten, H. Untersuchungen über die Gattung Gnetum. Ann. Jard. Bot. Buitenzorg 11: 195-218. pls. 17-19. 1893.

12. KARSTEN, H. Zur Entwickelungsgeschichte der Gattung Gnetum. Cohn's Beitr. z. Biol. d. Pflzn. 6: 337-382. pls. 8-11. 1893.

13. JaCCARD, P. Le développement du pollen de l'Ephedra Helvetica. Archives des sciences physiques et naturelles. III. 30: 280-282. 1893. See review in Bot. Centralbl. Beihefte 4: 230. 1894.

14. JACCARD, P. Recherches embryologiques sur l' Ephedra Helvetica (Inaug. dissertation. Zurich 1893). Bull. Soc. Vaudoise des sei. nat. 30: pls. 10. March, 1894. See review in Bot. Centralbl. 61: 111-113. 1895.

15. Lotsy, J. P. Contributions to the Life-history of the Genus Gnetum. Ann. Jard. Bot. Buitenzorg II. 1: 46-114. pls. $\mathscr{\&}-11.1899$. 


\section{CHAPTER V}

\section{FOSSIL GYMNOSPERMS}

The numerous fossil remains, from the early Paleozoic onward, which have been referred to Gymnosperms, have been determined chiefly by their anatomical features. This result has come from the nature of the available material, but to the morphologist it is suggestive rather than demonstrative. A vast amount of material has been named, which has been made somewhat available for the morphologist by Solms-Laubach, ${ }^{3}$ and most recently by Scott. ${ }^{6}$ Unfortunately, at this writing the second volume of Seward's Fossil Plants, which will deal with Gymnosperms, has not appeared. In any consideration of the phylogeny of Gymnosperms the historical point of view is absolutely essential, and in so far as there are any real morphological data among paleobotanical material they must be considered in the present connection.

Paleobotanists have recognized a group of fossil forms intermediate between Ferns and Cycads, to which Potonié has given the name Cycadofilices. They were especially abundant during the Carboniferous, and many of them have been described as Ferns. Some of the characteristic forms included in this proposed intermediate group are Heterangium, Lyginodendron, and Medullosa. The testimony in reference to the position of these forms is entirely anatomical, but it is extremely suggestive of the intermediate position claimed for the group by most paleobotanists. The historic evidence seems to be clear that the paleozoic Ferns merged gradually into the Cycads.

In addition to these transition forms, concerning which the morphologist must hold his judgment in suspense until the more essential structures have been discovered, there are certain extinct groups whose Gymnosperm character is undoubted. Among them the most conspicuous are the Cordaitales. 


\section{CORDAITALES}

The amount of information that has been accumulated concerning this great Paleozoic group is a matter of surprise. Not only are the vegetative structures abundantly preserved, even in

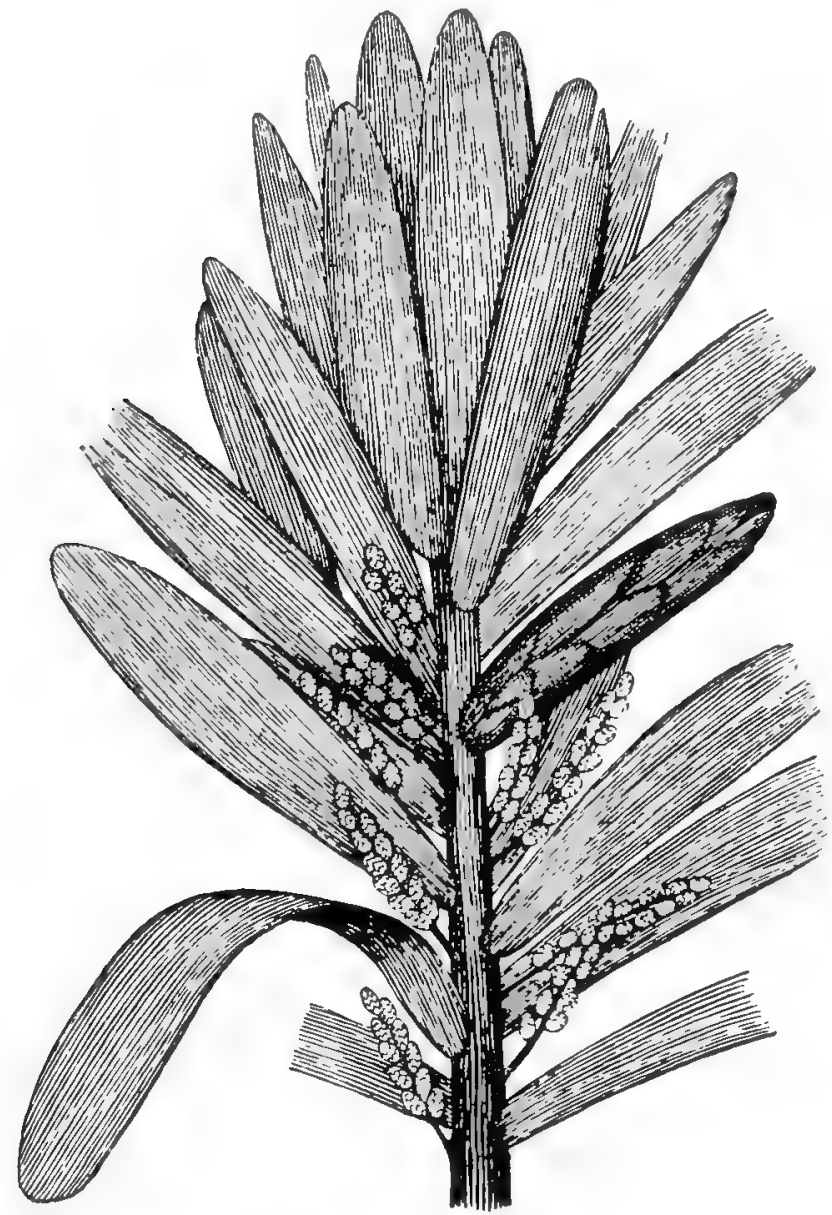

FI, 94,-Cordaites laevis: branch (restored) bearing leaves and strobili, and also a large bud.-After Grand' Eury.

their minutest details, but the more telling reproductive structures are known sufficiently to indicate general relationships. The Cordaitales becone evident in the Silurian, and increase 
in display to the Carboniferous, when they were astonishingly abundant, the leaves often being packed together in masses on every layer of the deposits. It seems clear that this was the prevailing Gymnosperm forest type of the Paleozoic. They were tall, rather slender trees, with shafts from 10 to 30 meters in height, branching only above, and with a dense crown of branches on which simple large leaves were produced in great abundance (Fig. 94). The leaves were usually long, ribbonlike, and parallel-veined, from 20 to 100 centimeters long and 15 to 20 centimeters broad. Scott ${ }^{6}$ says that " the habit of the Cordaitales must have been different from that of any trees with which we are now familiar. The species with comparatively short leaves may be compared with such Coniferae as Dammara (the Kauri Pine of New Zealand), or with some forms of Podocarpus, and these trees may best serve to give us some idea of the extinct family. But the large-leaved species must have had a habit very different from anything which we are accustomed to associate with the Gymnosperms at the present day."

The anatomical character of the stem is in general plan that of the Conifers, but the very large pith, which appears in transverse diaphragms, is more suggestive of the Cycads. As in Conifers, the tracheary tissue begins with spiral vessels lying next to the pith, and the secondary wood is composed exclusively of tracheids with bordered pits which are usually in two or more rows and are densely crowded, so that they have a hexagonal outline. As this secondary wood resembles very closely that of Araucaria, it was named Araucarioxylon by Kraus. The cortex contains strands of fibrous sclerenchyma, and isolated gum receptacles.

The leaves have conspicuous parallel veins, and in the majority of forms are elongated and strap-shaped, having very much the appearance of such monocotyledonous leares as those of I ucca or Dracaena. The venation is repeatedly dichotomous, excepting in the narrowest leaves, which are almost grasslike. Sometimes, however, the leares are short and obovate, and are said occasionally to branch dichotomously and even to become incised. In such leaf forms and venation there are suggestions of Ginkgo and of certain Ferns, while the ordinary elongated type, with its parallel veins, suggests Tumboa.

The anatomical character of the leaf is practically that of 
Cycads, and Scott calls attention to the fact that the structure of the leaf of Cordaites resembles that of a single pinna of the leaf of such a Cycad as Zamia, or one of the larger-leaved Araucarias. Leaf sections show a very xerophytic structure, hypodermal masses of sclerenchyma producing great firmness, if not rigidity. In the interior of the leaf, between the bundles, "transfusion tissue" is developed, the cells being elongated parallel to the epidermal layers, and so loosely organized as to appear like thin diaphragms between very large intercellular spaces, just as in the Cycads and Sciadopitys. Each vascular bundle is surrounded by a strong sheath, which connects with the hypodermal mass of sclerenchyma. Each bundle is of the mesarch type - that is, the secondary xylem occurs in two parts, with the primary spiral elements between them. This is exactly the structure of the leaf bundles of Cycads, and of other Paleozoic plants. The numerous stomata are depressed and occur in rows, apparently only upon the under surface. It is an interesting fact that the form and general structure of the leaf suggest the leaves of Conifers, while the anatomical features are more those of the leaves of Cycads.

The roots which are regarded as belonging to the Cordaitales show structures which relate them easily to the stem. In the various specimens recorded the vascular cylinder of the root is diarch, triarch, or tetrarch.

Chiefly through the researches of Renault, some knowledge of the strobili of a few species has been obtained. The strobili occur upon special shoots, which may be small or branched, and bear small catkinlike clusters (Fig. 94), which do not often exceed a centimeter in length. Externally the staminate and ovulate clusters are alike, although in some cases an ovulate strobilus may consist of a solitary ovule with few bracts. Each strobilus usually consists of a series of prominent leaflike bracts, in the axils of which the spore-bearing structures occur. It should be borne in mind that the following account is derived from the examination of a few sections of one or two species of a very large and probably diverse group.

The staminate strobilus consists of a thick axis covered by long spirally arranged bracts, which resemble reduced leaves. Many of the bracts are sterile; but especially toward the apex of the strobilus these are replaced by structures which may be 
fairly regarded as sporophylls. These sporophylls are narrower than the sterile bracts, and each bears at the apex a cluster of two to six sporangia, which are linear and erect, and dehisce by a longitudinal slit (Fig. 95, B). The sporophyll character of this structure is the view suggested by Renault, and according to this view it is morphologically a stamen. Solms-Laubach, however, regards each of these so-called stamens as a staminate flower, the
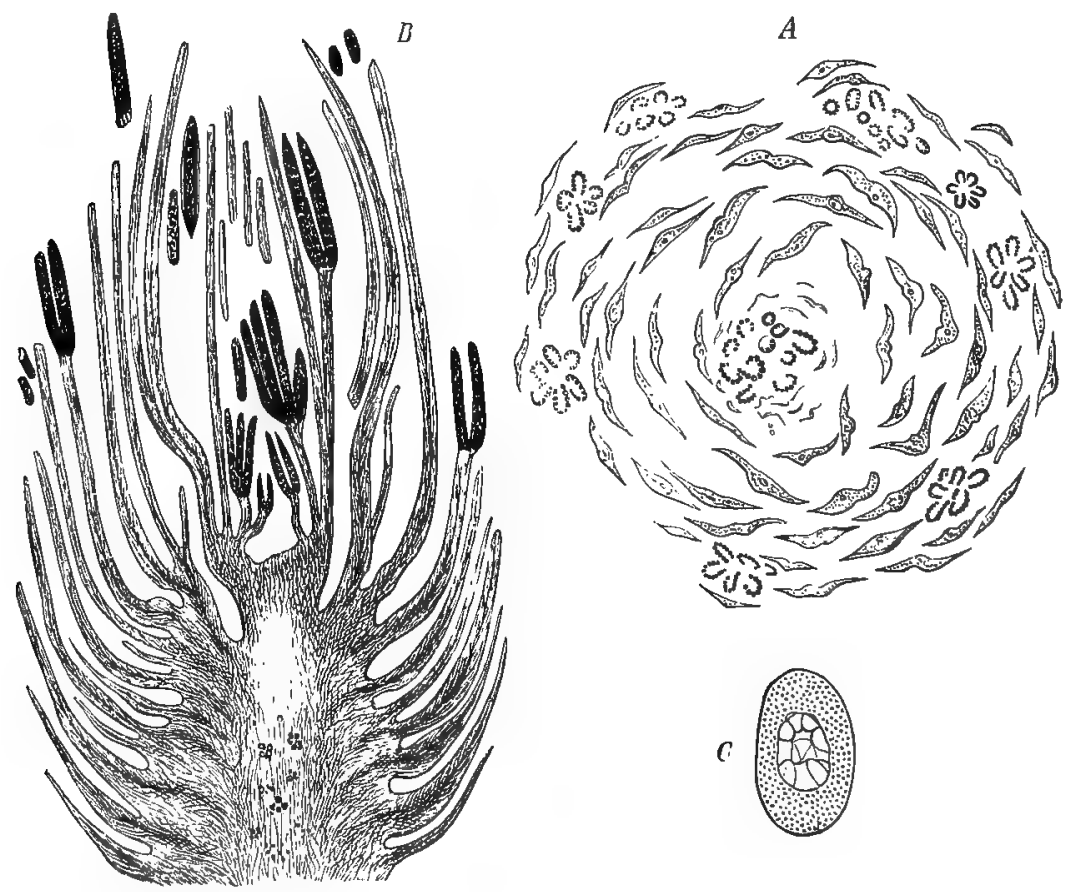

Fia. 95.-Corlaites, staminate strobilus: $A$, transverse section; $B$, longitudinal section of strobilus of C. Penjoni; $C$, a pollen grain, showing the group of internal cells.After Renault.

sporangia being sessile upon the summit of a pediccl. Such a view would suggest, as a parallel, the staminate flowers of $E$ phedra and Gnetum, in which two or more sessile sporangia are borne by a special axis which may be regarded as a pedicel, or at least a shoot. Scott suggests, howrever, that the whole cluster of strobili corresponds more to the staminate cluster of Ginkgo than to any other known Gymnosperm. In any erent, the inflorescence is different from that of any other Gymnosperm, and 
suggests a condition which needs further material before it can be homologized with any of them.

The pollen grains are remarkably well preserved, the exine being cuticularized and covered with a fine "shagreenlike" reticulation. As these spores have been found both in the sporangia and in the pollen chamber, there can be no doubt as to their relation to the ovules examined. The most remarkable feature of the group is the presence of a distinct tissue within the pollen grain while still in the sporangium. This tissue consists of a group of small polygonal cells against the wall on one side (Fig. 95, C). After pollination, while in the pollen chamber, the spore is said to increase very much in size; and the internal tissue develops still further. If these statements can be relied upon, the male gametophyte of Cordaitales is one of extraordinary interest, for it is far more primitive in character than that of any other known Gymnosperm, and points to the earliest stages of heterospory, earlier than in any existing heterosporous Pteridophyte. Whether the cells of this internal tissue are vegetative or sperm-producing is a matter of conjecture. In any event, the reduction of the male gametophyte is very much less than in any other known Seed-plant. Taken in connection with the presence of ciliated male cells in the Cycads and Ginkgo, and of a very deep pollen chamber which eventually deepens down to the embryo sac, it might be inferred that in Cordaitales there was little if any development of a pollen tube, and that swimming male cells, if not actually sperms, were discharged within easy reach of the archegonia. It must be remembered that in the Cycads and Ginkgo the pollen tube does not serve the purpose of a sperm carrier, and there is no reason to suppose that there was any such method of sperm transfer in the Cordaitales. In case the internal tissue of the pollen grain is antheridial, it would indicate the production of more numerous male cells than in any other Séed-plant. The whole structure is so suggestive of a theoretical transition stage between Pteridophytes and Spermatophytes that it is a temptation to make more out of it than the amount of observed material may justify.

The ovules occur in strobili similar to those which bear the stamens, but the bracts are longer and more overlapping, and a terminal tuft of long bracts crowns the strobilus. The solitary 
ovules are evidently cauline, being borne at the summit of a short bractlet-bearing shoot, which arises from the axil of a bract. As has been mentioned before, the ovules may be reduced to a solitary one in a strobilus, and the bracts may be very few in num-

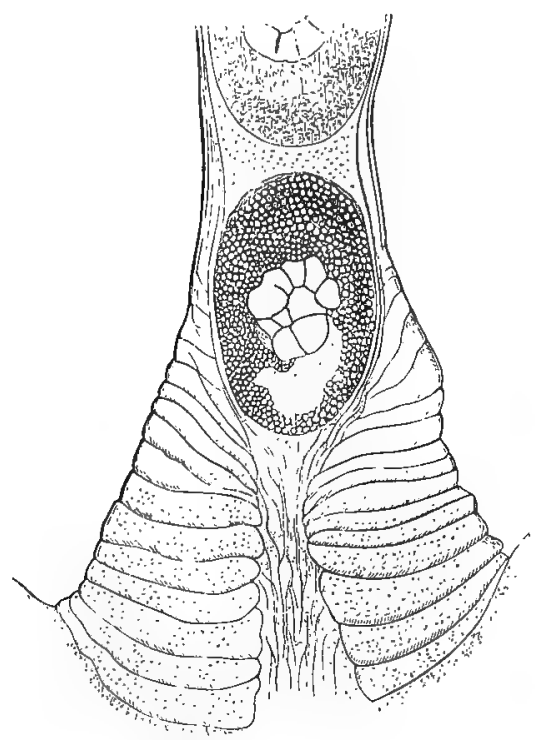

Fig. 96.-Cordianthus Grand' Euryi, showing the beak of the nucellus; wedged in the passageway are the large pollen grains, which show the shagreenlike surface and the internal group of cells.-After Renal'Lt.

ber. Two envelops are apparent, and permit the same diversity of opinion as exists in reference to the ovular envelops in the Gnetales. It seems altogether simpler to regard the two envelops in Cordaites as two integuments, although there is no tubular prolongation of the inner integument as in the Gnetales. The nucellus develops a remarkably prominent and persistent beak, composed of modified and heavy-walled cells, through which a passageway leads to a large pollen chamber (Fig. 96). The whole structure of the nucellus recalls the c'rcads and Ginkgo, and, as is the case with them, the nucellar tissue which caps the embryo sac disorganizes, pormitting the persistent beak to settle down upon the embryo sac (Fig. 97). There is also a striking resemblance to the nucellus of Ginkgo, as described by Hirasé, in the fact that the endosperm develops a protuberanee which supports the settling beak like a "tent-pole." Under the shelter of this improvised tent the archegonia are found and the male cells are discharged. The situation is so suggestive of Cyeads and of Ginhigo that one can hardly cscape the conviction that in the process of fertilization they are approximately the same. Traces of the archegonia have been found, so that their position is definitely determined.

The ovulate structures of the Cordaitales as described above 
are very suggestive of Taxus. The terminal ovule upon a short bractlet-bearing axis seems to be common to both. The similarity is increased by the fact that in most of the Cordaitales the testa develops into a fleshy outer layer and a stony inner one, which suggests the fleshy aril and stony seed coat of Taxus. Abundant remains of seeds are found, which apparently belong to the Cordaitales. In most cases the testa develops as indicated above, and closely resembles the seeds of Cycads and Ginkgo, as well as certain Conifers. In other cases, however, the seeds ripen dry and bear wings, which are exceedingly variable in form and position. Curiously enough, while seed sections have brought to light most of the structures referred to above, no embryos have been found. Probably their formation was much delayed, as in Ginkgo, Gnetum, and some Cycads.

It seems evident that we are dealing here with a group of Gymnosperms which deserves to be set apart as of equal rank

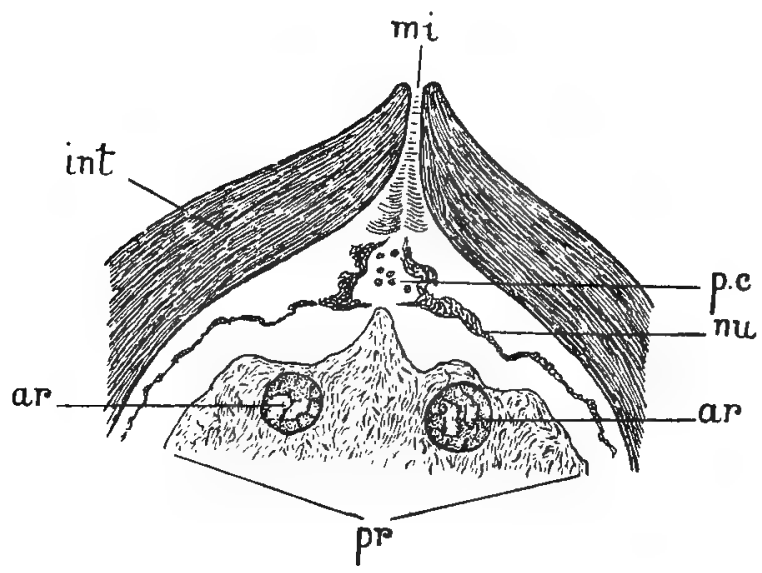

F1G. 97.-Cycadinocarpus Augustodunensis, showing upper part of ovule in longitudinal section: int, integument; $m i$, micropyle; $p c$, pollen chamber containing pollen grains ; nu, remains of nucellus ; $a r$, archegonia ; $p r$, endosperm.-After RENAULT.

with Cycadales, Ginkgoales, and Coniferales. It certainly presents important characters which serve to define it as clearly as any of the living groups, and its ancient character suggests that it must have been very intimately associated with the beginnings of the Gymnosperm phylum. 


\section{BENNETTITALES}

Cordaitales were the dominant Paleozoic Gymnosperms, and associated with them were the numerous Cycadofilices, whose synthetic character is indicated by the name. The true Cycadean type, however, does not become apparent until the Mesozoic; and all through that age, from the Triassic to the Lower Cretaceous, there was an extraordinary display of Cycadean forms. In anatomy and general vegetative characters the resemblance to living Cycads is undoubted, but in the majority of cases the spore-producing structures are remarkably different. These so-called anomalous Cycadean forms of the Mesozoic have been taken to represent a fifth great Gymnosperm phylum, which constituted the dominant vegetation of the Mesozoic, much as the Dicotyledons dominate the flora of to-day.

The remains of Bennettitales have been found in abundance in the explored regions of both hemispheres, and they have been described under a variety of generic names, Bennettites, Cycadeoidea, and Cycadella being the principal ones. The trunk is of the tuberous type, and is covered by an armor of closely imbricated persistent leaf bases. This character, together with the histological details of the stem tissues, the arrangement, form, and anatomy of the leaves, all have their counterpart in living Cycads. In two important respects, however, the Bennettitales differ from the Cycadales in external features. One is in the occurrence of numerous short, lateral, and probably axillary shoots which bore the inflorescence; the other is in the presence of scalelike hairs, which were packed between the leaf bases and about the inflorescence and its bracts, and resemble the socalled " ramenta" of Ferns rather than any known structure in Cycadales. The course of the leaf traces in Bennettitales differs decidedly from that in living Cycadales. In the latter, two bundles leave the stele near together, "and curving in opposite directions pass nearly halfway round the stem, thus entering the leaf base on the opposite side from their starting points." Scott ${ }^{6}$ describes the leaf traces in Bennettitales as follows: "I single bundle leaves the ring, starting from the lower angle of one of the meshes. . . A As the leaf trace passes out through the cortex, it assumes a horseshoe form, with the concare side in- 
ward. It then breaks up into about twenty smaller bundles, which enter the base of the leaf."

The ovulate inflorescence, however, is most remarkable, and unlike anything known in Gymnosperms. The description of Bennettites Gibsonianus given by Carruthers ${ }^{1}$ and by SolnnsLaubach, ${ }^{2}$ and found to apply to other forms, is as follows: The strobilus is a pear-shaped body, which terminates a short axillary shoot from the main stem, and in the species cited is about 5 centimeters long. Only fully ripened specimens, as shown by the seeds, have been examined. The strobilus is completely invested by bracts, which spring from the shoot and close in over the apex (Fig. 98).

An account of the details of the structure is adapted from Scott ${ }^{6}$ as follows: The stalk is expanded into a hemispherical receptacle, on which all the organs of the fruit are inserted. From the convex surface of the receptacle spring a great number of slender stalks, which pass vertically upward, or diverge slightly toward the curved surface of the fruit. Each of these stalks bears at its end a single erect sced, with the micropyle directed outward. The seeds are so placed

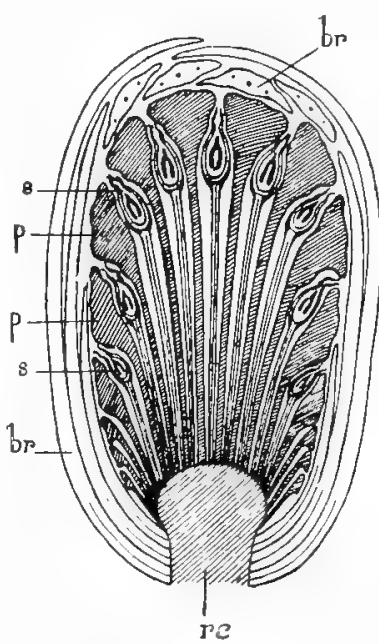

Fra. 98.-Bennettites Gibsonianus, diagram of ovulate strobilus : rc, receptacle; $b r$, ensheathing sterile bracts; $s$, seeds, each borne on a long stalk which arises from the receptacle, and in each an embryo with two cotyledons; $p$, dilated ends of the interseminal seales, which become confluent.-MIodified by ScotT, after Solms-LaUBach and Potoniḱ.

\section{that the longitudinal axis always} meets the surface of the fruit approximately at a right angle. The spaces between the stalks are packed with seales, which are dilated at their distal ends, between the seeds, so as to form a continuous envelop, only interrupted by narrow pits, into which the seeds exactly fit. The surface of the strobilus, therefore, appears as a contimuous tissue, which is perforated only by the micropyles of the seeds.

The whole structure presents the appearance of a remarkably 
modified strobilus, whose axis has become shortened and dilated into a receptacle, resulting in a massing of bracts and axillary sporangiferous shoots, the bracts in ripening organizing by

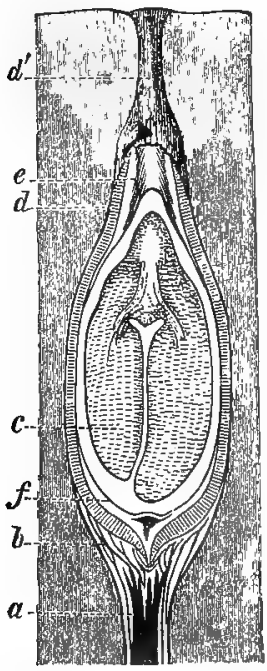

Frg. 99.-Bennettites . Gibsonianus, longitudinal section of seed : $a$, the entering vascular bundle; $b$, its expansion at base of nucellus; $c$, the embryo with two unequal cotyledons; $d$, the testa, terminating above in the tubular process $\left(d^{\prime}\right)$, which leads to the surfuce; $\longleftarrow$, probably remains of the nucellar beak, containing the pollen chamber.After Solms-Laubach. their tips a continuous investment. Whether this peculiar character of the bracts represents a post-fertilization change, or is developed before pollination, is a question for future discovery to answer. In any event, the solitary cauline ovule, terminal upon an axis of variable order, seems to represent an ancient Gymnosperm condition.

From the testa of the seed it is impossible to determine the nature of the integuments. The testa is closely adherent on the outside to the inclosing and confluent tips of the bracts, and shows three layers, the middle one composed of very thick-walled tissue, and much dilated toward the micropyle. The innermost layer forms the tubular micropyle, which becomes somewhat dilated at the apex and opens upon the surface of the strobilus. It would appear that two integuments are indicated, an inner delicate one continued into the tubular micropyle, and a much heavier outer one. The third or outermost layer of the testa, which is closely adherent to the surrounding bract tissue, may represent either an external layer of the outer integument, or a limiting layer of the bract tissue. Such an interpretation would conform in general with the structure of the ovule in all the more primitive Gymnosperm types.

Longitudinal sections of the seeds have also revealed a nucellar beak and a large pollen chamber, which suggests Cordaitales, Cycadales, and Ginkgoales. One of the most striking characters revealed by the seed, however, is the occurrence of a large dicotyledonous embryo completely filling the embryo sac, 
in fact the whole seed with the exception of the leak (Fig. 9r). The evident absence of a suspensor at once suggests Ginkgo, but the nearly complete di-alpeatrane of the comberem is without a parallel among Gymnosperms, so far as studied.

The morphological features of Bennettitales have been obtained heretofore almost exelusively from European material, but the remarkably rich display of this group in the Nesozoic flora of the United States, as developed by Professor Lester F. Ward and his associates, promises to supply much additional information. Large collections of this material are in the possession of the United States National Museum, and of the Yale University Museum, and the minuter structural characters are leing investigated hy Dr. G. R. IVicham, who has pullinhed preliminary papers concerning the "male flower" "and the "female fructification" 5 of species of Cycadeoidea. In some of the species, as $C$. Wielandi, the ovulate strobilus seems to conform almost exactly to the description of the strobilus of Bennet-

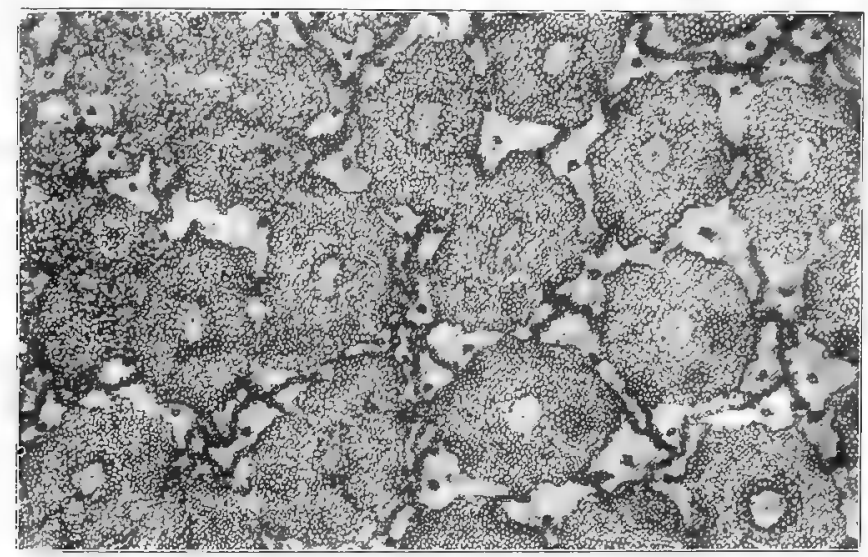

FIG. 100.-Cyculeodidea Fielandi, transverse section of a portion of the ovulate strobilus, showing the soed-stalks with their central buncles, and the intersemiual scalcs packed in between.-From a plotograph by C. E. BeEcher from a section made by G. $K$. Wiexand from a specimen in Yale University Museum.

tites Gibsonianus, as given above. There is the same broad receptacle bearing thickly set stalked seeds and interseminal scales (Fig. 100), and all ensheathed by overlapping bracts to form an ovoid body (Fig. 98).

The discovery of microsporophylls and of bisporangiate 
strolili, ${ }^{7}$ however, are the most interesting of Wieland's results thus far. The staminate strobili originally described * were taken from specimens of Cycadeoidea ingens, and apparently resemble the ovulate strobili of the group in all important fea-

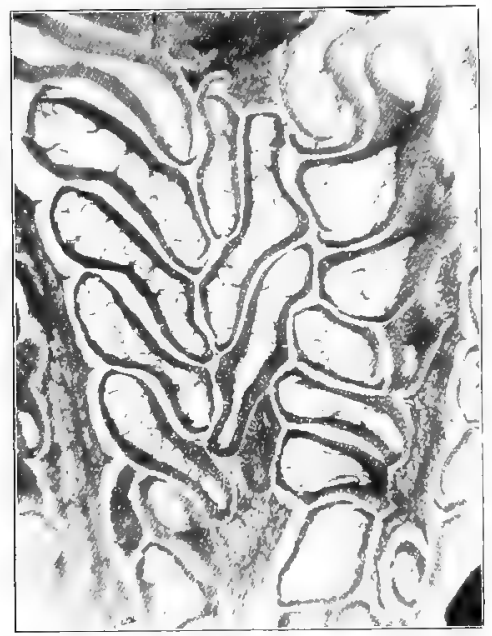

FIo. 101.-Cycadeoidea Dacotensis, a small part of a radial oblique section of a strobilus, showing some of the numerous synangia, $\times$ 8.-From preparation made by G. R. WIELAND from specimen in Yale University Museum. tures. Each strobilus is borne terminally upon an axillary dwarf shoot, and is ensheathed by a cluster of bracts. There is plain indication of the existence of a thick central axis upon which the numerous sporoplyyls were crowded, each sporophyll bearing numerous sori. This first meager description of a staminate strobihus has been supplemented by later preparations of Wieland from the strobili of the remarkable Cycadeoidea Dacotensis.5 With great generosity Dr. Wieland has placed these recent preparations at our disposal, and from them the following account is written:

The strobilus of Cycadeoidea Dacotensis is of the nsual ovoid form, being completely ensheathed by overlapping sterile bracts. Just within the ensheathing lracts there is a set of very prominent microsporophylls, whose abaxial surfaces are densely covered by well-defined sori (Fig. 101). $\Lambda$ s is evident from the figure, and much more conspicuously so in other preparations, the sori occur closely packed togcther in well-defined lines. The section of a sorus reveals characters unknown heretofore among Gymnosperms, and remarkably similar to those of Marattiacede (Fig. 102). The stmeture seems to be almost identical with that of the symangium of Marattia or of Danaea, and presents more the appearance of a plurilocular sporangium than of a sorus. Superficially thore is a wall of heavy cells, and between it and the regular sporangial chambers there is a more delicate tissue. The sporangial chambers, separated from one another 
by septa consisting of a single plate of cells, extend the full length of the broad synangium - that is, from its base to its apex, and form two rows, one on each face of the synangium, probably separated from each other by a few layers of intervening tissue. There is every evidence that the whole structure at first consisted of a mass of homogeneous tissue, in which regularly placed sporogenous masses were differentiated, each mass standing for a sporangium, exactly as in Marattia and in Danaea. At maturity the tissue between the two rows of sporangia apparently breaks down, at least the synangium splits into two valves, just as in the genera of Marattiaceae referred to. In Fig. 101 transverse sections of the two rows of sporangia may be seen in most cases, and in a few instances a different point of view has made visible the septa which separate the sporangial chambers. In Fig. 103 this is especially evident, where a single synangium presents a somewhat striking resemblance to the trabeculate sporangium of Isoetes.

We have used the terms sorus and synangium indiscriminately in describing these sporangial structures, upon the hypothesis that a synangium and a sorus are morphological equivalents. We recognize the fact that such a synangium as we have described may be regarded as a single plurilocular sporangium, resulting from the sterilization of potential sporogenous tissue, as in Isoetes. To discuss this question, however, does not fall within the purpose of this book. The important fact to the student of Gymnosperms is that among

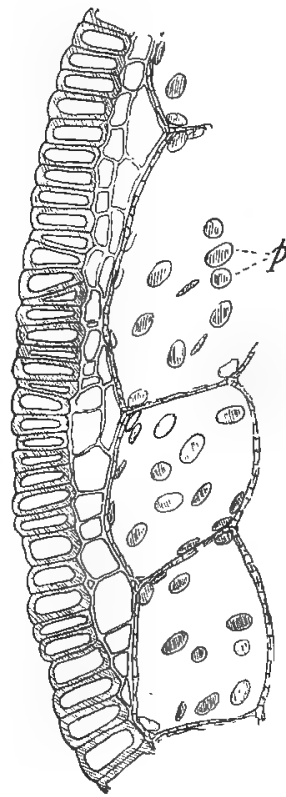

Fro. 102.-Cycadeoidea Dacotensis. transverse section of a. small portion of a synangium, showing outer layer of heavy-walled cells, the inner more delicate tissue, and three sporangial chambers containing pollen grains $(p)$. the Bennettitales there are forms whose microsporangiate structures are almost identical with those of such Ferns as Marattia and Danaea, whether these structures be called sori, synangia, or plurilocular sporangia. 


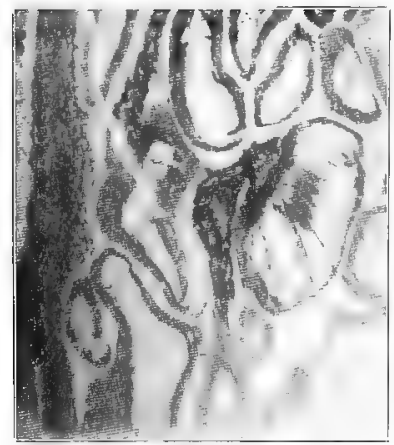

Fia. 108.-C'ycaleoineu Dacotensis, a very small part of a somewhat tangential longitudinal section of a strobilus, to show in side view the septa of a synangium, $\times 8 .-$ From preparation made by G. R. WIELAND from specimen in Yale University Museum.

We have described the strobilus of Cycadeoidea Dacotensis as consisting of a sheath of overlapping bracts, within which microsporoplyylls bearing Marattialike synangia occur. Within the microsporophylls, and towards the base of the strobilus, there is discovered what at first sight appears to be merely the conical apex of the axis of the strobilus, but which proves to be the ovulate region (Fig. 104). The conical receptacle is covered all over with the characteristic stalked seeds and "interseminal seales." In this case the "receptacle" really resembles an axis, and is of the ordinary Gymnosperm type; while in Bennettites and rertain species of Cycadeoidea the receptacle is flattened. This elongated ovulate axis is not always associated with a bisporangiate strobilus, as it occurs in strictly ovulate strobili. In Fig. 105 there is shown a transverse section of a young ovulate strolilus of Cycadeoidea colossal$i s$, whose axis is of the elongated type, as in the bisporangiate C. Darotensis (Fig. 101), but which is invested directly by the ensheathing sterile bracts. The illustration also shows some of the charactexistic ramenta which were packed between the superficial sheath and the ovuliferous

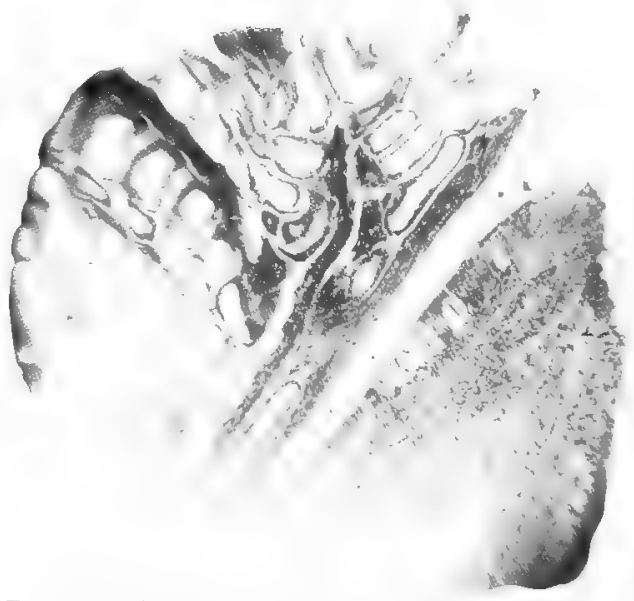

FIQ. 104.-Cycadeadea Darotensis, Iongitulinal section through basal portion of strobilus, showing at the left portions of synangium-covered sporophylls, and at the right the ovulate region of the strobilus, $x 4$. -From preparation marle by G. R. IVIELAND from specimen in Tale University Museum. 
part of the strobilus. The two distinct ovules show that they are young by the fact that their stalks have not elongated.

The monoecious habit among Gymmosperms is not unusual, although it has never been found among Cycads; but that this habit should take the form of a bisporangiate strobilus is especially interesting. Such strobili are found occasionally among Conifers, but they are regarded as abnormal (Fig. 59). To discuss the significance of these hi-porangiate strobili seems to us premature at present, since the results thus far announced are very meager as compared with those we have a right to expect. It may be well, however, to make the following statements. That a bisporangiate strobilus must have existed at some time among the ancestral forms of Gymnosperms has already been indicated by Tumboa, in which the association of the two forms of sporangia is more intimate than in Cycadeoidea. It seems evident, also, that a hisporangiate strobilus holds no more relation to an angiospermous "flower" than does a monosporangiate strobilus; and that neither type of strobilus among Gymnosperms is related to the angiospermous flower in any way. Whether

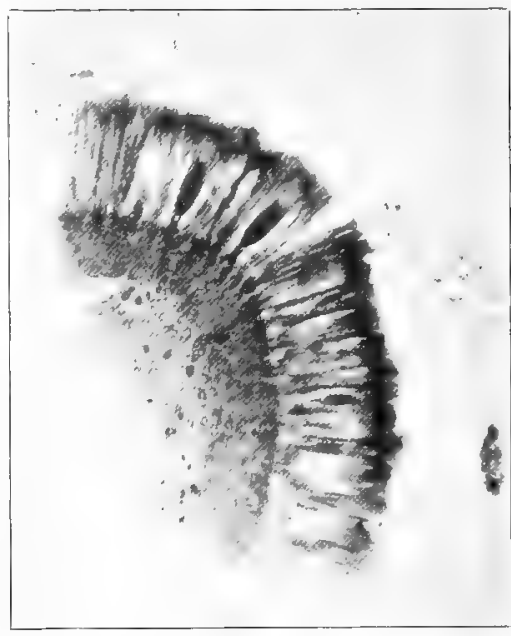

Fio. 105.-Cycadeoidea colossalis, transverse section through the central region of a very young strobilus, showing the axisbearing stalked ovules and interseminal scales, $\times 10$. - From preparation made by G. R. Wieland from specimen in Yale University Museum.

a bisporangiate or a monosporangiate strobilus is the more primitive is a question that probably finds its answer in the statement that both conditions exist in the most primitive forms. In Bennettitales, therefore, we are discovering interesting transitions between Ptcridophytes and living Gymnosperms, but there is not as much suggestion of Angiosperms as the living Gymnosperms have already given.

While the characters of Bennettitales justify the belief that they must be closely associated with Cycadales, the axillary 
dwarf shoots, the synangia, the remarkably modified and complex ovulate strobili, the occasional bisporangiate strobili, and the entire replacement of endosperm by an embryo which develops without a suspensor, are characters which strongly confirm the suggestion that the group should be regarded as one of the main divisions of the Gymnosperms.

\section{CYCADALES}

During the Mesozoic, along with the Bennettitales, the Cycadales undoubtedly existed, but the evidence is scanty. The reputation of the Mesozoic as "the age of Cycads" seems to have come rather from the abundant remains of Bennettitales. Certain remains may be taken fairly to represent Cycads, and doubtless numerous extinct genera of Cycads niay have existed, but no modern genus seems to have an unclouded title in the Mesozoic except Cycas, which has been recognized in the Rhaetic beds between the Lias and the Trias. The antiquity of Cycas confirms morphological opinion concerning it, as it is well separated from the other Cycads in features which are recognized as primitive.

\section{GINKGOALES}

The characteristic foliage of Ginkgo makes it easy of recognition, although some forms which have been referred to it may prove to be Ferns. However, putting together the evidence of foliage, flowers, and seeds, it is evident that the group was a rery widespread one in the Jurassic, and that the testimony is very strong for claiming its existence during the Paleozoic. The indefiniteness of its occurrence in the Paleozoic is based upon the fact of its association with the great group Cordaitales, into which it seems to merge. The conclusion reached by seott ${ }^{6}$ is as follows: "On the whole, the sum of the fossil evidence is of sufficient weight to prove the great antiquity of the gymnospermous family now represented by the Maidenhair tree, which appears to be best regarded as the one surviving member of an ancient stock, derived from the same crele of aftinity as the Paleozoic Cordaiteae, once the dominant type of Gymnosperms." 


\section{CONIFERALES}

It would be a matter of great interest if the relative antiquity of the various groups of Conifers could be determined. The varied structures of this dominant group are extremely perplexing to relate phylogenetically, and some definite historical data would go far toward suggesting the possible sequence. Upon morphological grounds one might be tempted to regard the Taxeae as the most primitive of Conifers, and Abieteae, especially Pinus, as the most highly specialized and recent, but so far as there is any historical testimony it is diametrically opposed to such a view.

The remains of undoubted Conifers occur from the later Paleozoic (Permian) on, and the total amount of material is enormous. Elaborate studies have sought to determine this material upon the basis of anatomical structure, and the literature of paleobotany is full of names suggestive of affinities with modern genera, but these methods have proved to be absoIutely untrustworthy. The sure evidence of well-preserved strobili associated with vegetative structures is lacking, so that the ancient history of this great group is still in a chaotic condition.

That the phylum is a very ancient one is evidenced by the fact that it is known to have existed during the later periods of the Paleozoic, and possibly earlier, but to what modern group these Permian forms are most nearly allied is absolutely unknown. Their resemblance to the Araucarieae in general vegetative habit has suggested an Arancarian affinity, but such evidence as the strobili furnish contradicts this.

Leaving these earliest Permian forms of doubtful affinity, the first suggestion of a modern group is furnished by the extinct genus Voltzia of the Upper Permian and Triassic, which has been referred, apparently on fairly safe evidence, to the Taxodieae, approaching Cryptomeria in the lobed character of the ovuliferous scale. True Araucarieae and Cupresseae can not be traced with certainty below the Jurassic; Abieteae, allied to Pinus, are not recognized earlier than the Wealden; while Taxeae have not been discovered lower than the Cretaceous. 
It is hardly possible that such a sequence represents the relative age of the distinct differentiation of these groups, for it can not be corroborated upon any theory of morphological relationship.

\section{LITERATURE CITED}

1. Carruthers, W. On gymnospermatous Fruits from the Secondary Rocks of Britain. Journal of Botany 5: 1 seq. 1867.

2. Solms-Ladbach, H. Ueber die Fructification von Bennettites Gibsonianus Carr. Bot. Zeit. 48: 789-798, 805-815, 821-833, 843847. pls. 9-10. 1890.

3. Solms-Laubach, H. Fossil Botany. 1891.

4. Wimland, G. R. A Study of some American Fossil Cycads. Part I. The Male Flower of Cycadeoidea. Am. Jour. Sci. IV. 7: 223-226. pls. $2-4.1899$.

5. Wieland, G. R. A Study of some American Fossil Cycads. Part III. The Female Fructification of Cycadeoidea. Am. Jour. Sci. IV. 7: 383-391. pls. 8-10. 1899.

6. Sсотт, D. H. Studies in Fossil Botany. 1900.

\%. Wreland, G. R. The Yale Collection of Fossil Cycads. The Yale Scientific Monthly 6: March, 1900. 


\section{CHAPTER VI}

\section{COMPARATIVE MORPHOLOGY OF GYMNOSPERMS}

Afrer having considered the details of structure presented by the living and extinct groups of Gymnosperms, it will be well to summarize them, and to obtain some conception of Gymnosperms as a single well-defined assemblage of forms. In this way the contrasting characters of the different groups may be emphasized, and the relations of Gymnosperms to Pteridophytes on the one hand, and to Angiosperms on the other, may be made to stand out more sharply.

\section{THE VEGETATIVE ORGANS}

THE STEM

$\Lambda 11$ known Gymnosperms are woody plants, almost all being trees. Whether the group ever contained herbaceous members or not is an interesting but an unanswerable question. The short tuberous stems of many Cycads, of Bennettitales, and of Tumboa; the simple, palmlike column of certain Cycads; the tall trunk of the Cordaitales, branching only above; the excurrent shaft of most of the Conifers and of Ginkgo with its symmetrical monopodial branching; the trailing and spreading habit of certain Conifers; the straggling shrubby habit of Ephedra; and the high climbing habit of certain species of Gnetum, is a list which seems to exhaust the possible habits of woody stems. Amidst all this great variety of form there is a uniform xerophytic structure, indicating adaptation to relatively hard conditions of living. The habitats of Gymnosperms to-day indicate that they either are not at home in the more genial conditions affected by Angiosperms, or have not been able to maintain themselves in competition with this great group. In any event, it seems clear that the conditions for plant 
life are more favorable now than at any previous time in the history of plants.

The anatomy of the stem shows characters in common with Pteridophytes, others suggestive of Dicotyledons, and still others peculiar to the group. In all Gymnosperms the primary vascular bundles are open collateral, contain true tracheae, and are organized into a hollow cylinder inclosing a more or less extensive pith region. At this point the resemblance to the dicotyledonous stem ceases. In many Cycads the primary cambium is very short-lived, a succession of secondary cortical cambium cylinders developing successive sets of cauline bundles. This development of successive cortical cylinders of vascular strands seems to represent a very ancient type of stem. It is displayed by Cycas, Encephalartos, Macrozamia, and Bowenia among the Cycads, belonged to the Bennettitales, and is apparently shared by Gnetum and Tumboa. Furthermore, these secondary vascular bundles are of the concentric type in Cycas, and give evidence in Macrozamia and Bowenia of a transition from the concentric to the collateral type. The concentric type of bundle is also displayed in the peduncles and leaves of other genera, as Stangeria, Zamia, and Ceratozamia, as well as in Bennettitales $_{r}$ It is significant, also, that this type of stem characterized the so-called Cycadofilices.

The gradual abandonment of the cortical cambiums, and the conversion of concentric into collateral bundles, seems to have taken place in the Cycads, as evidenced by Zamia, Dioon, and Stangeria. In Cordaitales, Coniferales, and Ephedra, the primary cambium develops all of the secondary vascular tissue, and the collateral type of bundle is fixed. It is interesting to note that Cordaitales, the most ancient distinct group of Gymnosperms, are included in this last list, and it indicates an improbability that there is any definite and single type of Gymnosperm stem that can be regarded as the most ancient.

The development of tracheids with bordered pits has long been regarded as a distinctly Gymnosperm character, but they seem to be wanting in Tumboa, and are said to be present in certain fossil Pteridophytes. In any event, it is a trpe of vessel displayed almost exclusively by Gymnosperms, and almost without exception among them. A transition from tracheids with bordered pits to true tracheary vessels seems to be evident in 
Ephedra, if not in the other Gnetales, while the very regular massing of these tracheids to form the secondary wood is characteristic of Conifers.

It is also worthy of note that there are no distinct nodes in the stems of Cycadales and Bennettitales; that they are usually evident, but often indistinct in Ginkgoales, Cordaitales, and Coniferales; and that in Gnetales they are distinctly developed.

THE LEAF

The spiral and cyclic arrangements are definitely separated by great groups, the Cupresseae and Gnetales being cyclic, the other Gymnosperms spiral.

The tendency to heterophylly is a very strong one, scale leaves being associated with foliage leaves in every great group. In Cycadales there is a regular alternation of the two types, while in Coniferales the extreme of diversity is reached. In Coniferales the primitive type of shoot seems to have consisted of axes all of which were clothed with free needle leaves, which later became intermixed with scales; while in the highly specialized genus Pinus the foliage leaves abandon the main axes, and are pushed out on dwarf shoots to the extremities of the branch system.

The foliage leaves are remarkably varied in form and size and venation, being pinnately branched and more or less dichotomously veined in Cycadales and Bennettitales, broad and dichotomously veined in Ginkgoales, characteristically acicular in most Coniferales, ribbonlike and parallel-veined in Cordaitales and Tumboa, and broad and reticulately veined in Gnetum. It is also a noteworthy fact that the fernlike leaves of some of the Cycads also show the characteristic circinate vernation of Ferns.

Although variable in form and venation, the foliage leaves of Gymnosperms are fairly constant in certain points of structure, all of them, with few exceptions, developing rigid protective structures, and having a limited distribution of the vascular system, with a characteristic development of " transfusion tissue."

THE ROOT

So far as studied, the roots of Gymnosperms seem to be of very uniform structure. As distinct from Pteridophytes the 
sbrong tap root is to be noted; while the peculiar origin of the root cap seems to distinguish the group as a whole from Angiosperms. There is no distinct calyptrogen, but the periblem layers are continuous over the tip, and according to Strasburger each with its own meristem. As the layers over the tip continue to divide, the outer ones become more or less separated and dead, and function as a cap. The primary vascular cylinder seems to be very uniformly diarch, a simpler type than prevails among Dicotyledons, and much simpler than in Monocotyledons.

\section{THE SPORE-PRODUCING MEMBERS}

\section{THE MICROSPORANGIUM}

The microsporangia are always developed in connection with a strobilus or strobiluslike structure, which in the genus Cycas is terminal upon the main axis, and may be so in the other genera of Cycadales; but it is lateral in all other Gymnosperms, and either axillary or borne upon axillary spur shoots. The strobili are almost universally monosporangiate, Tumboa giving evidence of a former bisporangiate condition in the occurrence of a sterile ovule in the staminate "flowers," and the Bennettitales, in some cases at least, displaying a bisporangiate strobilus.

In most Gymnosperms the microsporangia seem to be distinctly foliar, being borne by an undoubted sporophyll. In some genera of Cycadales (as Cycas, Macrozamia, Ceratozamia, and Stangeria), and in Bennettitales, so far as known, the very numerous sporangia, often in definite sori, and borne upon the under surface of broad scales, are very suggestive of Filicales. In other Gymnosperms, however, the sporophylls are more modified, and the sporangia are much fewer in number, frequently being reduced to two upon each sporophyll. In certain genera of Cycads (as species of $Z_{\text {(tmia) }}$ ) and of Conifers (as Tarus), the peltate type of sporophyll is found, and the sporophyll of Ginkgo may be regarded as a modification of it. In Conifers in general, however, the expanded portion of the sporophyll develops in the plane of the stalklike base.

In Ephedra and Gnetum the microsporangia seem to be distinctly cauline, and are developed near the apex of a short lateral axis which bear's coalescent bractlets ("perianth"); but in Tumboa there seems to be no question as to the sporophyll 
character of the sporangium-bearing structure, which usually consists of six monadelphous stamens. Of course it is possible to conceive of the so-called short axis in Ephedra and Gnetum as monadelphous stamens, but this hypothesis does not seem to be necessary.

Special interest attaches to the sporangium-bearing structure of the Corclaitales, both on account of its peculiarity, and on account of the antiquity of the group. It is a debatable question whether the structure is a sporophyll or a lateral axis, but in any event the sporangia are erect and in a terminal cluster. The terminal position of the sporangia finds its parallel in all the genera of Gnetales, and is no indication of their foliar or cauline character. It seems that the most primitive type of microsporophyll among Gymnosperms must be that displayed by $C y c a s$ and its related genera, and by the Bennettitales, but the oldest microsporophylls known, those of Cordaitales, seem to hold no clear relation to them. It may be that when the sporeproducing members of the Cycadofilices are known some light will be thrown upon the evolution of the microsporophyll in Gymnosperms.

The development of the sporangium in all the forms investigated is quite uniform, and is of the ordinary eusporangiate type. The archesporium consists of a hypodermal plate of cells, which divide by periclinal walls, separating an outer and sterile wall layer from an inner sporogenous one. By subsequent divisions a wall of three to seven layers is developed outside of the sporogenous tissue and within the epidermis. $\mathrm{Nu}$ merous spore mother cells are organized, and in this condition the sporangium passes the winter or the rest period.

Gymnosperms seem to be universally anemophilous, although it is claimed that Tumboa is probably entomophilous. The extreme of anemophilous adaptation has been attained by the winged pollen grains of the dominant modern genera Pinus and Podocarpus.

THE MEGASPORANGIUM

The presence or not of a megasporophyll is one of the problems of the group, which has been discussed sufficiently elsewhere. It seems clear that the ovules are both foliar and cauline. 'They are certainly foliar in most if not all of the Cycad- 
ales, and probably so in Ginkgo, although in the latter case the supposed carpel is a very rudimentary structure. Among the Cordaitales, Bennettitales, Gnetales, and Taxaceae, the ovules seem to be clearly cauline; while among the Pinaceae the carpel is said to be "reduced to the ovule"; the latter therefore would be essentially cauline. One is tempted to regard the foliar ovule as the more primitive type, and to trace the reduction of the sporophyll from $C y c a s$, where it is well expressed, through Ginkgo, in which it is much reduced, to the Conifers and Gnetales, in which it is eliminated. To such a view, however, the testimony of history is opposed, for among the Cordaitales, the most ancient of recognized Gymnosperm groups, the ovules were plainly cauline, and apparently so among the Bennettitales, the most ancient of the Cycadean forms. 'The eridence seems to be that the foliar ovule does not necessarily indicate a more primitive group than the cauline, and that the distinction between these two types of ovules is more arbitrary than real, often impossible to apply, and of no special significance.

The question of integuments is another Gymnosperm problem. The usual statement is that the integument is single in all Gymnosperms except Gnetum, and this certainly expresses the result of ordinary observation. If the definition of integument be restricted to such structures as receive the name in Angiosperms, then it can be claimed that one integument is the rule among Gymnosperms. If it be allowed, however, that the integument may become so modified as to lose its character of an ordinary investment of the ovule, we are launched into a discussion whose merits can not be decided by demonstration. It is not clear why it is essential for so ancient and dircrsified a group as the Gymnosperms not to vary in the number of its integuments.

As opposed to the ordinary view that one integument characterizes the group, and Lotsy would cren include Gnetum in this generalization, is the view of Člakovsky that the whole group is characterized by two integuments, the outer one of which is often remarkably modified. This view certainly sweeps into one category a number of problematical structures and has the attractiveness of uniformity. The application of this theory would result somewhat as follows: Among the an- 
cient Cordaitales the most obvious explanation of the ovule section is the presence of two distinct integuments, and the testa of the Bennettitales indicates the same fact in that group. In Cycads, Ginkgo, Cephalotaxus, Podocarpus, etc., the outer fleshy and inner bony layers may be regarded as representing two integuments structurally, which have become connate; while in Taxus, Dacrydium, Microcachrys, etc., the outer fleshforming integument has remained or has become distinct as the so-called "aril." In the Pinaceae the most remarkable modification is displayed, the outer integument having entered into the structure of the "ovuliferous scale." Among the Gnetales the inner integument is produced into the remarkably long and tubular micropyle, while the outer one has been usually designated a "perianth."

It is evident that between distinct bracts on the one hand and a genuine integument on the other there may be all sorts of intergradations, and that a hard-and-fast morphological line probably does not exist. We can recognize in all Gymnosperms a single undoubted integument, but whether the next outer structure should be called an outer integument, an aril, a perianth, an ovuliferous scale, or what not, seems impossible and perhaps unimportant to decide.

The nucellus of the group presents some features which seem to be important. In the whole group there is a remarkable development of sterile tissue above the single or several sporogenous cells, which thus appear imbedded in the chalazal region of the ovule. Among the more primitive Gymnosperms (Cordaitales, Bennettitales, Cycadales, and Ginkgoales) this sterile mass differentiates into a firm persistent beak at the apex, and a loose tissue between the beak and the embryo sac. In the same groups a deep pollen chamber is developed within the beak, the loose tissue becomes broken down by rhizoidlike pollen tubes, and the beak settles down upon the embryo sac. This uniform structure in all the more primitive forms certainly has to do with the more primitive phases of siphonogamy, which will be discussed more fully under fertilization. Among the Coniferales and Gnetales the beak is not developed, but the outer micropylar layers of the nucellus are of firmer tissue than those beneath, and occasionally the tip of the nucellus breaks down into a cuplike depression which holds the pollen grains, as has been ob- 
served in Pinus and in Gnetum. An exception must be made of Tumboa, in which the persistent beak is formed, which is riddled with passageways but contains no definite pollen chamber. Sequoia also presents an interesting modification, the micropylar sterile region of the nucellus being but feebly developed, the sterile tissue beneath the sporogenous mass growing in a remarkable way and being penetrated by the elongated and tubelike megaspore.

The origin of the deep-seated sporogenous cell or group is an open question for most forms. The general statement is that it is derived from an archesporium consisting of hypodermal cells, and that periclinal divisions cut off outer sterile cells which build up the remarkable mass of sterile tissue. This has been definitely observed in a very few forms and has been inferred for the rest. It coincides with the well-known sequence in Angiosperms, and may prove to be true of Gymnosperms in general, but we have not been able to verify it as yet in Pinus. The first differentiation of sporogenous tissue usually visible is the appearance of one or several sporogenous cells in the chalazal region of the ovule.

\section{THE GAMETOPHYTES}

THE FEMALE GAMETOPHYTE

With the exception of Tumboa and Gnetum, the structure of the female gametophyte is very uniform in Gymnosperms, and recalls in a general way the female gametophrte of such heterosporous Pteridophytes as Selaginella and Isoetes. This resemblance, however, is very general, and should not be pushed too far, as is shown by recent investigations.

The general statement is that the mother cell divides and organizes a row of potential megaspores, the lowest of which becomes the functional megaspore. Wre have recontly succeeded in verifying this statement for Pinus (Fig. 106). In this genus we have repeatedly observed a single cell, usually cent rally placed in the chalazal region, which by its increase in size and its contents is evidently the functional mother cell; but we have only a single proparation to show that it clevelops a row of potential megaspores. We suspect that in Pinus, and in many other Gymnosperms, there is but a single primary sporogenous cell, 
which passes over directly into a mother cell, and that the peculiar differentiation and breaking down of a zone of tissue about it has led to the impression of a sporogenous mass.

In some cases where there is more than one mother cell, two or more megaspores begin to develop, and in Sequoia the sterile megaspores are prominent and persistent, but as a rule one soon becomes dominant at the expense of the rest and of the adjacent nucellar tissue.

The mother cell increases in size in the usual way, and early in its history begins to germinate. The sequence of events seems to be very uniform, being free nuclear division (usually about eight simultaneous divisions), parietal placing of free nuclei in a cytoplasmic layer, organization of parietal tissue, and gradual filling of the embryo sac by centripetal growth. The cases of Tumboa and Gnetum are peculiar in that there is a distinct polarity in the tissues of the sac, and an appearance of reproductive cells in a sac not filled with tissue. In Tumboa the micropylar region of the sac contains cells but loosely aggregated when the reproductive cells appear, while in Gnetum the micropylar end of the sac, and in some species the whole sac, contains only free nuclei when fertilization occurs. Indications of the same tendency in other forms are not lacking. In Sequoia it is reported that while cell formation is taking place

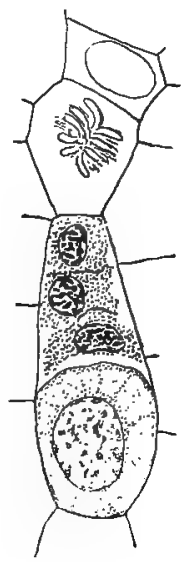

Fig. 106.-Pinus Laricio, showing the four potential megaspores derived from the mother cell, $\times 666$. at the two extremities of the sac, free nuclear division continues in the middle region, the sac thus being distinctly divided into its reproductive and nutritive regions.

In the development of the archegonia, which are variable in number and in distribution, there are some features that seem peculiar to the group. The neck canal cell series, which is by no means prominent in the Pteridophytes, is not represented at all in the Gymnosperms; and the ventral canal cell, cut off immediately before fertilization, is usually very minute and ephemeral. Probably the most noteworthy fact in connection with the archegonium is the organization of a sheath of 
jacket cells about the central cell, which through numerous wall pores empty their contents, nuclei and all, into the rapidly enlarging central cell, and this material remains conspicuous in the large egg: The neck is quite variable in structure, organizing from two cells to several tiers with eight cells in each tier. Probably the most common structure is two tiers with four cells in each tier. The two-celled neck, so far as recorded, occurs in Cycadales, Ginkgoales, Tsuga Canadensis, and Cephalotaxus Fortunei. Tumboa and Gnetum develop no archegonia, as would be expected from the nature of their endosperm tissue. In Tumboa the archegonium initials are selected, but no division occurs, the egg organizing directly in the initial; while in Gnetum the eggs are as free and naked as in the Angiosperms. The last two forms are particularly suggestive in representing the possible method of transition from a compact ante-fertilization endosperm to one that consists of free nuclei when fertilization occurs, a very characteristic feature of Angiosperms.

\section{THE MALE GAMETOPHYTE}

While information concerning the germination of the microspores of Gymnosperms is still very much needed, enough has been observed to indicate the general character of the gametophyte. In most cases one or two vegetative ("prothallial") cells are first cut off. In Cycadales a single such cell is cut off and persists; in Ginkgoales and Ephedra two such cells are successively cut off, the first being ephemeral; while in Abieteae two cells are cut off, and both are ephemeral. In certain forms studied, as Taxus, Juniperus, Cupressus, and $S e$ quoia, no evidence of vegetative cells has been obtained. It should be remembered, however, that these cells are cut off rapidly and are very ephemeral, so that traces of them may be lost quickly, or they may easily escape observation. Tre venture the opinion, therefore, that one or two regctative cells, more or less evanescent, will be found to be of common occurrence among G.ymnosperms-cells which are almost unknown among Angiosperms.

The large cell which remains after the cutting off of the vegetative cells we have taken to be the morphological equivalent of the antheridium initial as it appears in the heterosporous 
Pteridophytes, although we recognize the fact that there may be grounds for considering the generative cell as the antheridium initial, in which case the structures can not be homologized with those of the heterosporous Pteridophytes. This large cell divides unequally, giving rise to a sterile tube cell (the larger), which is concerned with the development of the pollen tube, and a smaller primary spermatogenous cell or generative cell. The spermatogenous series, beginning with the generative cell, seems to be very uniform in Gymnosperms, and is longer by one generation than is the series in Angiosperms. The generative cell divides and forms the stalk and body cells, the former of which functions no further. The body cell divides and organizes the two functional male cells, the morphological equivalents of the sperm mother cells of Pteridophytes. If the stalk cell, sister of the body cell, should also divide, four male cells would result, and the sequence would be that of Isoetes. In the Cycads these male cells become ciliated, through the very peculiar activities of blepharoplasts, but they should not be regarded as the homologues of the multiciliate sperms of Pteridophytes. Whether the ciliated sperm of Ginkgo is the transformed mother cell or not is a matter of doubt, for although the details of its formation seem to be identical with those of the ciliated male cells of the Cycads, there is evidence that they are organized within the mother cells and discharged, in which case they are the morphological equivalents of the sperms of Pteridophytes. It is barely possible that there is here a transition form between a discharged ciliated sperm and a retained sperm resulting in a ciliated mother cell.

Some meager evidence as to the nature of the male gametophyte of Cordaitales is very suggestive. Within the well-preserved pollen grains a mass of tissue has been observed, whose nature, whether vegetative or antheridial, it is impossible to determine. In either event it indicates a much more primitive male gametophyte than has been found in any living Gymnosperm. The testimony from the structure of the male gametophyte indicates an origin of Gymnosperms from forms whose gametophytes had more complex vegetative tissue than is shown by any living heterosporous Pteridophyte. 
FERTILIZATION

It is now known in Cycadales and Ginkgoales, forms with ciliated male cells or sperms, that these cells are not transferred through the pollen tubes. Branching tubes penetrate in every direction through the loose nucellar tissue which lies between the beak and the embryo sac, and seem to be purely absorptive in function. As the nucellar tissue is broken down, the pollen grains containing the body cell are brought into close proximity to the archegonia, so that when the ciliated male cells or sperms are organized and discharged they are able to reach the necks by swimming. As the Cordaitales and Bennettitales show nucellar structures identical with those of Cycadales and Ginkgoales, it seems reasonable to suppose that their pollen tubes, if any existed, were also rhizoidal in character, and that their sperms were ciliated. The conclusion seems to be inevitable that pollen tubes appeared primarily as absorbing organs, and that their function as sperm carriers is one that should be regarded as secondary.

In the other groups of Gymnosperms, so far as known, the pollen tube, while retaining more or less of its rhizoidal character, is also distinctly a sperm carrier, and this function seems to be associated with the development of nonciliated male cells. In these cases the whole of the contents of the swollen tip of the tube, consisting prominently of the two male cells, tube nucleus, and stalk-cell nucleus, has been observed to be discharged into the cytoplasm of the egg.

The development of two male cells seems to be thoroughly established throughout the Spermatophytes. In the grouped archegonia of Cupresseae both male cells may function, and the same may be true in the case of branching trbes which are sperm carriers. In Taxus, however, the inequality of the male cells indicates that one of them has long since ceased to be functional.

The discharge of the contents of the pollen grain or pollen tube is in every case closely preceded by the cutting off of the ventral eanal cell. Occasionally the nucleus of this cell becomes as highly organized as that of the egg, and there is reason to believe that in some instances it may be fertilized. The cytoplasm of the egg receives the rarious contents of the grain or tube, but everything remains near the periphery of the cyto- 
plasm except the nucleus of the male cell, which advances toward that of the egg and becomes imbedded in it. There is some evidence that the fusion of the two nuclei does not involve a fusion of their chromatin, and that the male and female chromatin continues to exist as separate groups at the first segmentation of the fusion nucleus. How far this may be true of Gymnosperms in general it is impossible to say, but in any event it is an interesting problem, involving not only a departure from the habit of other known plants, but also a resemblance to the phenomena of fertilization observed in certain animals, as Ascaris.

It is perhaps well to call attention to the fact that the cytoplasm of the male cell enters the cytoplasm of the egg and fuses with it. The importance of this in connection with fertilization is a matter of opinion rather than of demonstration. It is certainly true that the nucleus of the male cell of Gymnosperms, and probably of all plants, becomes relatively very large, being covered by a thin layer of cytoplasm. Whether this cytoplasm is directly necessary to fertilization, or merely necessary to the male nucleus preceding fertilization, is a question for the future to answer.

\section{THE EMBRYO}

The germination of the oospore is one of the most characteristic features of Gymnosperms, and although the details seem to vary widely there is underneath them all a general method which belongs to the group and has been observed in no other. A natural series may be arranged, beginning with the Cycadales. In them, germination begins with free nuclear division, followed by the placing of the free nuclei in a cytoplasmic layer which lines the wall of the oospore and surrounds a central cav. ity. The free nuclei then organize a parietal layer of cells, which are apt to be more or less massed at the base of the oospore (towards the main mass of the endosperm), the whole of the endosporic tissue being known as the proembryo. These basal cells of the proembryo then begin a remarkable elongation, forming the very long and massive suspensor, which bears at its tip the group of cells which is to develop into the embryo proper. The three regions of the embryo which thus appear are (1) the proembryo, an endosporic structure, which relates the embryo to 
the nutritive supplies stored up in the egg, (2) a suspensor, which develops from the proembryo and relates the embryo to the nutritive supplies of the endosperm, and (3) the embryo proper.

In the case of the Coniferales the same sequence is repeated, except that free nuclear division becomes much reduced, usually resulting in but four nuclei, which pass to the base of the oospore and organize a definite basal proembryo of three tiers of cells, with four cells in each tiex. It is interesting to note that in Cephalotaxus Fortunei the free nuclear division is not so restricted, but results in eight or sixteen free nuclei, which pass to the base and organize the proembryo. The difference between Coniferales and Cycadales, therefore, is that in the former the number of free nuclei is restricted, and therefore the formation of a proembryonic tissue takes place only in the basal region of the oospore. In both cases the suspensor is formed by the elongation of some of the cells of the proembryo, and in Coniferales a single plate ("rosette") of cells retains connection with the nutritive supplies of the oospore, rather than a parietal layer. Another feature in the formation of the proembryo of Coniferales is worthy of note. The first walls formed about the nuclei of the primary basal group are not an accompaniment of nuclear division, but seem to be formed directly by fibers investing the nuclei, and they do not cut off these nuclei from the general cavity of the oospore above. The subsequent walls which result in building up the tiers are associated with nuclear division, but the uppermost nuclei always remain exposed to the cavity of the oospore, and are separated from one another by walls which extend more or less into the mass of the oospore.

In Ephedra free nuclear division also occurs, two to eight such nuclei being formed, but they organize as free cells, and do not form a definite tissue. As a consequence, the cells act independently, and each one develops a long tubular process (suspensor), the bulbous base remaining in touch with the nutritive supplies of the spore, and at the tip of each suspensor an embryonic cell is cut off. This independence of the cells may be observed also in Pinus, where, although there is a regular tier formation of the proembryo, each cell of the suspensor set develops a separate suspensor bearing at its tip an embryonic cell. 
In Tumboa and Gnetum, free nuclear division, which in Ephedra sometimes results in but two nuclei, is abandoned entirely, and the whole oospore behaves as do one of the free cells in Ephedra, elongating in suspensor fashion, and eutting off at the tip an embryonic cell.

The case of Ginkgo is a very interesting departure from the ordinary sequence. The germination of the oospore begins with free nuclear division, but suspensor development is entirely omitted, and as a consequence the oospore is filled with a compact tissue which organizes directly into the embryo, and this encroaches upon the endosperm by the growth of the whole mass. It is important to note that the method of Ginkgo was also that of the Bennettitales, and this fact raises the question whether this does not represent the type of embryogeny among the primitive Gymnosperms, in which the three embryonic regions of modern Gymnosperms have not been differentiated. No evidence as to the embryo of the Cordaitales has been 'obtained, so that the very important testimony which they might give is not available. If this be the more primitive type of embryogeny, it would follow that the conspicuous suspensor of most living Gymnosperms is a structure of secondary origin in the group. However, these two types of embryogeny may not hold any definite relation to each other.

The development of the embryo proper seems to follow no rigid sequence. The first division may be transverse or vertical, and the subsequent divisions may be in almost any order or direction. Perhaps too much emphasis has been laid upon the sequence of events in the earliest stage of the embryo; at least, the data now at hand seem to indicate the entire lack of a definite sequence. A study of the organization of the growing points of the great body regions, however, should lead to important results, but unfortunately the knowledge of Gymnosperms in this regard is too meager to justify any definite statement.

It is evident that polyembryony is natural in the group, and numerous embryos in various stages of development are commonly found imbedded in the endosperm, but for more than one embryo to come to maturity seems to be a rare phenomenon, 


\section{CHAPTER VII}

\section{THE PHYLOGENY OF GYMNOSPERMS}

ANy statement as to the phylogeny of a group must be largely hypothetical. The data upon which opinions are based are never sufficient, but such opinions serve to coordinate knowledge and to suggest profitable research. Only a small fraction of living forms have been studied adequately; while the extinct forms, which represent the early history essential to phylogeny, will probably never be known except in an uncertain and fragmentary way. In the case of Gymnosperms we have the advantage of dealing with a woody group, whose fossil remains may be taken to represent their ancient history with unusual completeness. But even in the presence of an abundance of remains, the facts of greatest service to morphologists are for the most part inaccessible.

Before suggesting a possible phylogeny for the group and its various members, it may be well to state certain factors which must enter into any consideration of such a subject. In the first place, it should be remembered that it is exceedingly improbable that any important group of living forms has been derived from another group of living forms. Resemblances in structure which are regarded as essential may be pointed out, but this is not likely to mean the origin of one group from the other; it may mean that the two groups caln be traced to one, probably now extinet, which combines the characters now differentiated. Most living groups are best regarded as divergent rather than consecutive series.

Another important point is that similar changes in structure may have appeared independently in different lines. The response of organisms in their structure to environment is deeper seated than we werc once inclined to belicre, and testimony from the sinilarity of certain structures, when contrilry to the 
testimony of the majority of other structures, argues feebly for recent community of origin. For example, we are compelled to believe that so important a condition as heterospory was attained independently by several lines. To put into the same genetic group all heterosporous Pteridophytes would be regarded as a morphological absurdity. If heterospory appeared independently in several lines, the same conclusion must be reached in reference to its natural outcome, the seed, and the polyphyletic origin of the Spermatophytes becomes extremely probable. A corollary of the point last mentioned is that a living group may not have a common phylogeny with any other living group showing similar structures. For example, we are not necessarily restricted to the heterosporous Pteridophytes in searching for the ancestral forms of the Gymnosperms, for the latter may represent a distinet heterosporous line. While this increases the perplexities of phylogeny, it broadens its horizon, and homosporous Pteridophytes may be included in the search for the origin of the Gymnosperms.

What seems to be a conspicuous error in many schemes of phylogeny is the tendency to focus attention upon very few structures. It may be that the structures selected are the most significant in a general way, but the organism is a plexus of structures and must be considered in its totality. Very different structures must have been laid hold of by the processes of evolution, and it may not be possible to relate the resulting forms properly upon the basis of any one or two structures. With all of these uncertainties in mind, we may reach not a clear phylogeny of the Gymnosperms, but a clearer understanding of the complexity of the problem and of the uncertainty of conclusions.

Ever since Hofmeister's classic researches, it has seemed clear that the Gymnosperms have been derived from Pteridophyte stock. As this view meets general consent there is no need to discuss it. It was also natural for a time to regard Gymnosperms as phylogenetically intermediate between Pteridophytes and Angiosperms, for it was not easy to believe that such a structure as the seed could have appeared in more than one genetic line. It is probably not going too far to say that there is now no serious opposition to the view that the Gymnosperm and Angiosperm lines are genetically independent. The problem, therefore, has to do with the relation of the Gymno- 
sperms and the Pteridophytes to one another, and does not concern itself in any way with the Angiosperms.

Assuming the origin of Gymnosperms from Pteridophytes as true, the question is as to the monophyletic or polyphyletic origin of the group. Was a single group of archaic Gymnosperms derived from Pteridophytes, which subsequently differentiated into distinct lines; or have several Gymnosperm lines originated independently from the Pteridophyte stock? The great diversities which exist among the living representatives of the group suggest a polyphyletic origin; but the numerous important structures in common, and more than all the testimony of the great Gymnosperm plexus of the Paleozoic, seem to argue far more strongly for a monophyletic origin. The reasons for these views will become more clear as the interrelationships of the groups are considered.

Assuming the monophyletic origin of Gymnosperms, the question is at once suggested as to the special group of Pteridophytes which gave rise to them. Curiously enough, each of the three living phyla of Pteridophytes has been claimed as having been the source of the Gymnosperms. The hypothesis which looks to the Calamodendreae among the Equisetales as the ancestral forms has now few if any supporters. A persistent hypothesis, however, associates Grmnosperms with the Lycopodiales, through such ancient forms as the Sigillarieae, an origin which is claimed for the Coniferales, even when the Creads are acknowledged to be of filicinean origin. A third hypothesis would derive the Gymnosperms from the Filicales. As Professor Scott has said: * "These interpretations, whether right or wrong in the particular cases, at least indicate the broad fact that important anatomical characters, which we are accustomed to associate with Gymnosperms and dicotyledonous Phanerogarns, were in Paleozoic times common to a large proportion of the vascular cryptogams. Community of secondary tissue formation, however, is by itself no proof of affinity, and the problem must be attacked on other lines."

The view which we maintain is that the Creadales have undoubtedly been derived from the Filicales, and that it is impossible to dissociate the other Gymnosperm lines from the Creads.

* Studies in Fossil Botany, p. 513, 1900. 
In the present state of knowledge, it is scarcely necessary to recapitulate the arguments which favor a filicinean origin for the Cycads, especially since this view seems to meet with general consent.

Approaching the subject from the historical standpoint, we find that the Filicales represent an extremely ancient line, probably the most ancient of the Pteridophyte lines, reaching back in history at least into the Silurian. The group is such an ancient one that in all of its known history it seems to be entirely independent of the other series of Pteridophytes. In the Carboniferous the display of Filicales was an extraordinary one. Associated with true Ferns was an almost equally extensive group which the paleobotanists have called Cycadofilices. The latter forms so much resembled the Ferns in outward aspect that they were originally all included among the Ferns; but subsequent study has revealed the fact that their anatomical structure shows a remarkable commingling of Fern and Cycad characters. Unfortunately, the sporangia of Cycadofilices are unknown, and the group must at present remain of indefinite limitation. The main fact, in the present discussion, however, is that a very extensive group, showing characters intermediate between Ferns and Cycads, existed during the Carboniferous period in connection with undoubted Ferns. From the great antiquity of the Filicales, the conclusion seems to be rational that during the great vegetative display of the Carboniferous there was a differentiation of the phylum, which gave rise to the Cycadofilices, the old Fern stock continuing to display itself in forms which would be recognized to-day as members of the Marattiaceae. The first conclusion, therefore, would be that the Gymnosperm phylum began with the separation of the Cycadofilices from ancient marattiaceous Filicales.

Associated with the Cycadofilices during the Carboniferous was the great group Cordaitales, undoubted Gymnosperms, and related to both Cycads and Ferns in such a way as to suggest very definitely an origin similar to that of the Cycads. Whether the Cordaitales came directly and independently from the Filicales or not is doubtful, but our judgment favors the latter view, since we are inclined to regard the Cycadofilices as representing the original indefinite plexus out of which all the Gymnosperm lines have been derived. 
During the Carboniferous, also, forms appeared which seem to be referable distinetly to Ginkgoales, a line which in its beginnings has seemed hard to distinguish from certain of the Cordaitales. Ginkgo has always been peculiar in its combination of Cycad and Conifer characters, and this may be accounted for by its early origin in connection with the Cycadofilices and Cordaitales.

During the Mesozoic there appeared the Bennettitales and Cycadales, the former making much the greater display. It is reasonable to suppose that these two lines were derived either independently or together from the Paleozoic Cycadofilices.

The historic evidence concerning the Coniferales is most indefinite and uncertain. The group, as we understand it today, is relatively modern, but there is no evidence as to the relative ages of the two great lines, Taxaceae and Pinaceae, which compose it. For a long time the genus Araucaria has been regarded as the most ancient representative of the Conifers, but this idea seems to have arisen from the Araucaria-like wood which is so abundant in the Paleozoic, which has proved to beIong to the Cordaitales. Just which of the Conifer lines is the most ancient remains for future investigation to discover; that the line as a whole was an offshoot from the Cordaitales seems to us most probable. In fact, the Cordaitales, as ordi-

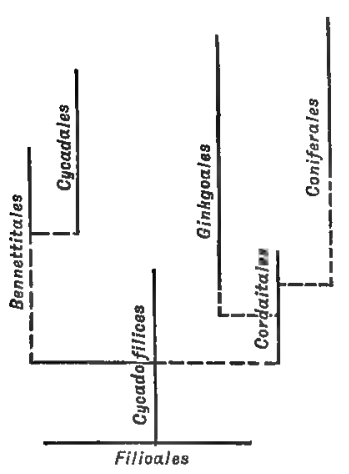
narily recognized in the Carboniferous, seem to us to be forms well on their way toward the Coniferales.

In reference to Gnetales, there seems to be absolutely no historic evidence, and morphology is equally at fault. That the three genera now existing are a fragmentary representation of some ancient line seems to be a reasonable conclusion; and the characters are related so distinctly to those of other Gymnosperms that it seems hardly a question but that the group has the same origin, although one can not venture upon any more detailed hypothesis.

In order to summarize clearly the statements made above, the accompanying diagram is introduced, but it must be interpreted in a most general sense. 
The origin of both Gymnosperms and Angiosperms is bound up with the evolution of heterospory and the seed habit, a statement concerning which is presented in the following quotation:* "The evolution of heterospory seems simple enough. The physiological differentiation of the spores was complete when prothallia became persistently dioecious. This division of labor is to be expected in the case of two such distinct functions as the production of antheridia and of archegonia. A prothallium producing both sex organs equally well may be regarded as in a state of equilibrium, an equilibrium which is disturbed by any conditions which favor the production of one sex organ rather than the other, in this case probably nutritive conditions. This disturbance of the equilibrium of a bisexual prothallium would certainly find expression first in a dioecious tendency, and finally in a dioecious habit. With the habit once fixed the morphological differentiation of spores becomes inevitable, since the nutritive requirements of the two prothallia are so different. The evolution of heterospory seems to be one of the simplest of selective processes, with inequalities of nutrition to furnish the variations. From this point of view it would seem natural to expect that it may have been derived frequently from homospory.

"The retention of the megaspore, however, does not seem to be so simple a problem. In a certain sense it is correlated with the reduction of the gametophyte, since retention would not seem practicable until reduction had proceeded far enough to make the gametophyte endosporic. Even greater reduction, however, is attained by the male gametophyte, but the spore is shed. It should be noted that even in the case of the microspore the male gametophyte is usually completely organized before pollination; but the fact remains that the reduction does not compel retention.

"It has seemed to me that this phenomenon is to be explained by the law of progressive sterilization. This law certainly finds expression in the megasporangia of heterosporous Pteridophytes, in which the sterilization of mother cells is conspicuous. This method of increasing the nutrition of the fertile cells is too common a phenomenon to need illustration; but it is

* Coulter, John M. The Origin of Gymnosperms and the Seed Habit. Bot. Gaz. 26 : 153-168. 1898. 
a tendency that would seem very consistent with the development of megaspores, whose peculiar work holds so definite a relation to abundant nutrition. For this very reason high numbers of microspores may be continued, and a diminishing number of megaspores produced. This would reach its culmination in the production of but a single megaspore by a sporangium, and a proportionate increase in the size of the megaspore. With the development of a single spore imbedded in a sterile tissue, shedding becomes not only mechanically difficult, but meaningless, since the necessity for scattering abroad of gametophytes, to avoid competition, has disappeared. It is further true that the development of such a spore involves nutritive supplies from numerous neighboring cells, and a certain amount of retention becomes necessary for this reason. Still further, the advantage to a single megaspore in being retained, thus securing more abundant outside nutrition during germination, would fix the habit if any selective process were at work. For these various reasons it would seem evident that when the sterilization of a megasporangium had reached its extreme limit, by organizing a single spore, retention is likely to follow sooner or later. If this line of reasoning be true, the seed habit might have been developed in any heterosporous line."

Some unpublished results obtained by Miss F. M. Lyon in a study of species of Selaginella are of interest in this connection. The usual condition was found in which the one or two fully formed megaspores were retained in the sporangium until they germinated. Not only this, but the eggs were fertilized and complete embryos formed within the retained megaspores. Fertilization was effected not by the entrance of sperms into the sporangium, but by the entrance of microspores, which discharged sperms through papillate protuberances. Moreover, the embryos thus formed escaped from the megaspores and developed into young plantlets, a strobilus often being covered with sprouting plantlets. It should be remarked that such strobili had fallen from the parent plant, so that the megaspores had been physiologically separated from the individual which produced them, but the permanent retention of the megaspore within the sporangium, without interfering with germination, fertilization, or the development and escape of the embryo, are facts which contain a morphological suggestion. 


\section{CHAPTER VIII}

\section{GEOGRAPHIC DISTRIBUTION OF GYMNOSPERMS}

Althогgh geographic distribution is not a part of morphology, the special student of Gymnosperms should be familiar with the broad outlines of the distribution of the living forms. No attempt will be made to trace the historical migrations of the different types, or to indicate natural physiographic areas. It is sufficient to say in general that there is evidence that most of the forms once had a very much more extended range than now, and that the change has consisted chiefly in a gradual restriction of the areas occupied.

\section{CYCADALES}

At present the Cycads are strictly tropical forms, the nine genera, containing something less than one hundred species, being distributed about equally between the oriental and occidental tropies. Cycas, the oldest genus, containing about sixteen species, is the most widely distributed oriental genus, ranging throughout tropical Asia, the East Indies, and the Australian region; while Macrozamia, with fourteen species, and the monotypic Bowenia, are strictly Australasian; Encephalartos, with twelve species, and the monotypic Stangeria, are African.

In the occidental tropics the largest genus is Zamia, with about thirty species, ranging through tropical and subtropical America; Ceratozamia, with six species, and Dioon, with two species, are Mexican; while the monotypic Microcycas is Cuban.

It may be remarked in general that Cycas and Zamia represent the typical Cycads of the two hemispheres, while the other genera represent relatively isolated forms which bear the stamp of local conditions. 


\section{GINIKGOALES}

This phylum, once with a very extensive range, is now represented by a single species, which is restricted to China and Japan. It was formerly supposed that even this species had long ceased to exist in the wild state, but specimens which seem to be undoubtedly wild have been reported from China and Japan.

\section{CONIFERALIS}

While Cycads are tropical forms, Conifers belong as distinctly to temperate regions, forming vast forest areas, especially in the northern hemisphere. A map indicating their general distribution would show a heavy north temperate massing, and a lighter south temperate massing, the two separated from one another by a broad tropical belt, traversed in but two placesnamely, the East Indian region and the Andean region. These northern and southern masses contain mostly what are regarded as different generic types, Pinus dominating at the north, and Podocarpus at the south. Through the East Indian region Podocarpus reaches China and Japan; while the northern genus Libocedrus reaches Australia by the same route, and penetrates far into temperate South America by way of the Andes. Aside from these two lines of communication, and these two genera, there is no crossing of the tropies, all other genera being exclusively northern or southern.

Before considering the main groups in some detail, it may be well to note a few facts of general interest. By far the greatest Conifer display in genera and species is that which borders the Pacific Ocean, the chief areas being the ChinaJapan region, the Australasian region, and western North America; while the whole of this vast border region is occupied by Libocedrus.

The most remarkable displays of endemic genera are found in the China-Japan and the Australasian regions, the former containing Cephalotaxus (4 spp.), Pseudolarix (1 sp.), Keteleeria (2 spp.), Sciadopilys (1 sp.), Cunninghamia (1 sp.), Cryptomeria (1 sp.), Glyptostrobus (2 spp.), Thujopsis (1 sp.); while the latter contains Microcachrys (1 sp.), Phyllocladus (3 spp.), Agathis (4 spp.), Arthrotaxis (3 spp.), and 
Actinostrobus ( 2 spp.). It will be noted that these restricted genera are well distributed among the great groups, and that many of them are monotypic. It should be remarked that in the Australasian region are included the principal East Indian and Polynesian Islands. Many of these genera are known to have had formerly a very extensive range, but why the two regions cited, together constituting practically the western coast region of the Pacific, should have proved so favorable for the preservation of types otherwise extinct is an interesting question.

The other regions of endemic genera are North America, with Sequoia and Taxodium; and South America, with the monotypic Saxogothaea of the mountains of Patagonia.

Throughout the northern hemisphere the dominant and widely distributed genera are Pinus (70 spp.), Juniperus (30 spp.), Abies (20 spp.), Picea (12 spp.), Cupressus (12 spp.), Larix (8 spp.), and Taxus (8 spp.). There is also a remarkable pairing of western North America and eastern Asia in the display of certain genera, those common to both regions, besides the genera which extend broadly over both hemispheres, being Torreya, Tsuga, Pseudotsuga, Thuja, Libocedrus, and Chamaecyparis.

The distribution of forms in the southern hemisphere is modified by the fact that temperate conditions occur in three great isolated areas, although this has not resulted in as complete a separation of genera as might have been expected. The dominant Podocarpus (40 spp.) is the only genus which occurs in all three of the south temperate regions; but in the display of certain other genera there is a pairing of the continents, the Australasian region always being one menber of the pair, and, with one exception, South America being the other member. For example, Fitzroya (2 spp.), Libocedrus (8 spp.), Dacrydium (12 spp.), and Araucaria (10 spp.) are common to the Australasian region and South America; while Callitris (15 spp.) is common to the Australasian region and Africa. The occurrence of Callitris in the Mediterdanean region of Africa, however, suggests a comparatively recent connection with the Australasian region through the northern border region of the Indian Ocean.

In considering the distribution of the great groups of Conifers one is struck by their somewhat rigid geographic limitation, 
and by the occasional remarkable exceptions. Six apparently natural groups are recognized, and each one belongs distinctly to the northern or southern hemispheres. Taxeae, Abieteae, Taxodieae, and Cupresseae are distinctly northern types; while Podocarpeae and Araucarieae are just as distinctly southern. It is interesting to note that this division disregards the great division of Conifers into Taxaceae and Pinaceae.

While this is the general fact, it is more or less true in the different groups. For example, Abieteae are absolutely northern and Araucarieae are absolutely southern, but the same sweeping statement can not be made in reference to the other groups. Podocarpeae, characteristically southern, are represented in eastern Asia by species of Podocarpus. The three remaining northern groups, however, show more striking departures from the rule. Taxeae are represented in the Australasian region by the endemic genus Phyllocladus; Taxodieae are represented in the same region by the endemic genus Arthrotaxis; while Cupresseae are represented in the southern hemisphere by the endemic Australasian genus Actinostrobus, the AustralasiaAfrican genus Callitris, and the Australasia-South American genus Fitzroya. The occurrence of these widely separated genera, on the hypothesis that they belong to the same natural group, is an interesting problem.

From the standpoint of isolated genera, however, the Taxodieae are most interesting, for all of the seven genera are very much restricted. Glyptostrobus is Chinese, Sciadopitys is Japanese, Cunninghamia and Cryptomeria are China-Japanese, Arthrotaxis is Australasian, Sequoia is Californian, and Taxodium is east North American.

The facts presented above can be understood only when connected with the ancient distribution of the various groups, but unfortunately the history of Conifers is not in a condition to supply definite testimony.

\section{GNETALES}

Ephedra (30 spp.) occurs in the arid regions of Mediterranean Europe and adjacent Asia, as well as of America, in tropical, subtropical, and temperate conditions. Gnetum (15 spp.) ranges through the tropics of both hemispheres. The 
monotypic Tumboa is narrowly restricted to certain extremely arid regions of western Africa.

'There is nothing in the geographical distribution of this group to suggest anything in common, for the range and conditions are as diverse as are the structures. If they are genetically related, they must represent a very ancient and once widely distributed phylum, but no sure evidence of its presence has been discovered among fossil plants. 


\section{SUMMARY OF LITERATURE CITED}

ARnold, W. Bull. Soc. Imp. Nat. Moscow. 329-341 pls. 2. 1899 (1900). See review in Jour. Roy. Micr. Soc. 1900: 428.

A RNoldI, W. Beiträge zur Morphologie der Gymnospermen. III. Embryogenie von Cephalotaxus Fortunei. Flora 87: 46-63. pls. 1-3. 1900.

Beiträge zur Morphologie der Gymnospermen. IV. Was sind die "Keimbläschen " oder "Hofmeister's-Körperchen " in der Eizelle der Abietineen? Flora 87: 194-204. pls. 6-7. 1900.

BaILlon, H. Recherches organogéniques sur la Fleur femelle des Conifères. Ann. Sci. Nat. IV. 14: 186-199. pls. 12-13. 1860.

BeCCARI, O. Della organogenia dei fiori feminei del Gnetum Gnemon L. Nuovo Giorn. Bot. Ital. 7: 91-99. $187 \%$.

Belajefr, W. Zur Lehre von dem Pollenschlauche der Gymnospermen. Ber. d. deutsch. bot. Gesell. 9: 280-286. pl. 18. 1891.

Zur Lehre von dem Pollenschlauche der Gymnospermen. Ber. d. deutsch. bot. Gesell. 11: 196-201. pl. 12. 1893.

Blackman, V. H. On the Cytological Features of Fertilization and Related Phenomena in Pinus silvestris L. Phil. Trans. Roy. Soc. 190 : 395-426. pls. 12-14. 1898.

Bower, F. O. On the Germination and Histology of the Seedlings of Welwitschia mirabilis. Quart. Jour. Micr. Sci. 21: 15-30. pls. 3-4. 1881.

On the Further Development of Welwitschia mirabilis. Quart. Jour. Micr. Sci. 21: 571-594. pls. 22-23. 1881.

The Germination and Embryology of Gnetum Gnemon. Quart. Jour. Micr. Sci. 22: 278-298. pl. 25. 1882.

BraUn, A. 1853.

Brongniart, A. Recherches sur l'Organisation des Tiges des Cycadées. Ann. Sci. Nat. I. 16: 389-402. pls. 20-20. 1829.

Brown, RoBert. Character and Description of Kingia, a new Genus of Plants found on the S. W. Coast of New Holland, with Observations on the Structure of its Unimpregnated Ovulum and the Female Flower in Cycadeae and Coniferae. 182\%. Included also in Brown's Miscellaneous Botanical Works, Vol. I, 1866. 
Carruthers, W. On Gymnospermatous Fruits from the Secondary Rocks of Britain. Seemann's Jour. Bot. 5: 1 seq. $186 \%$.

CASParY, R. De Abietinearum floris feminei structura morphologica. Ann. Sci. Nat. IV. 14: 200-209. 1860.

Č́lakovskÝ, L. Zur Gymnospermie der Coniferen. Flora 62: 257264, 272-283. 1879.

Zur Kritik der Ansichten von der Fruchtschuppe der Abietineen. Abhandl. d. königl. böhm. Gesell. d. wiss. VI. 11: 1882.

Die Gymnospermen. Abhandl, d. königl. böhm. Gesell, wiss. VII. 4: $1-148.1890$.

Die Gymnospermen; eine Morphologisch-phylogenetische Studie. Abhandl. d. königl. böhm. Gesell. wiss. VIII. 4: 1890.

Nachtrag zu meiner Schrift über die Gymnospermen. Engler's Bot. Jahrb. 24: 202-231. 1898.

Die Vermehrung der Sporangien von Ginkgo biloba L. Oester. bot. Zeitsch. 50: 229-237, 276-283, 337-341. 1900.

Chamberlain, C. J. Winter Characters of certain Sporangia. Bot. Gaz. 25: 125-128. pl. 11. 1898.

Oogenesis in Pinus Laricio. Bot. Gaz. 27: 268-280. pls. 4-6. 1899. Coker, W. C. Observations on the Gametophyte and Embryo of Taxodium distichum. Johns Hopkins Univ. Circ. 19: 45-46. 1900.

Costantin and Morot. Sur I'Origin des Faisceaux libéro-ligneux supernuméraires dans la Tige des Cycadées. Bull. Soc. Bot. France 32: 173. 1885. See review in Bot. Centralbl. 24: 101102. 1885.

Coulter, J. M. Notes on the Fertilization and Embryogeny of Conifers. Bot. Gaz. 23: 40-43. pl. 6. $189 \%$.

The Origin of Gymnosperms and the Seed Habit. Bot. Gaz. 26: 153-168. 1898.

DE BARY, A. Comparative Anatomy of the Vegetative Organs of the Phanerogams and Ferns. English translation. 1884.

Drckson, A. Observations on some Bisexual Cones occurring in the Spruce Fir (Abies excelsa). Trans. Edinburgh Bot. Soc. 6: 418-422. 1860.

Dixon, H. N. Fertilization of Pinus silvestris. Ann. Bot. 8: 21-34. pls. 3-5. 1894.

EICHLER, A. W. Ueber Welwitschia mirabilis, ete. Flora 47: 459464, 473-479, 489-496, 508-510, 513-520. 1863.

Sind die Coniferen Gymnosperm oder nicht? Flora 54: 241247, 260-272. 1873; and later papers.

Coniferae in Engler and Prantl's Nat. Pflanzenfam. 2' : 108. 1889.

Engelmann, G. Morphology of the Carpellary Scales of Coniferae. Am. Jour. Sci. III. 12: 469-470. 1876.

FankHauser, J. Entwickelung des Stengels und Blattes von Ginkgo. Bern. 1882. 
FUJII, K. On the Different Views hitherto proposed regarding the Morphology of the Flowers of Ginkgo biloba. Bot. Mag. Tokyo 10: 15-25, 104-110. pl. 1. 1896.

On the Morphology of the Spermatozoid of Ginkgo biloba. Bot. Mag. Tokyo 14: 260-266. pl. \%. 1900.

GombeL, K. Outlines of Classification and Special Morphology. English translation. 316. 1887.

Organography of Plants. English translation. 153-155. 1900.

Goroschankin, J. Zur Kenntniss der Corpuscula bei den Gymnospermen. Bot. Zeit. 41: 825-831. pl. $\tau_{A}$ A. 1883.

Ueber den Befruchtung-Process bei Pinus Pumilio. 1883.

Hirasé, S. Études sur la Fécondation et l'Embryogénie du Ginkgo biloba. Jour. Coll. Sci. Imp. Univ. Tokyo 8: 307-322. pls. 31-32. 1895.

Études sur la F'écondation et l'Embryogénie du Ginkgo biloba. Jour. Coll. Sci. Imp. Univ. Tokyo 12: 103-149. pls. ‘-9. 1898.

HoFmeister, W. Embryobildung der Phanerogamen. Jahrb. f. wiss. Bot. 1: 82-188. pls. 7-10. 1858.

Vergleichende Untersuchungen. English translation. 1862.

Lehre der Pflanzenzelle. 120. $186 \%$.

Hooker, J. D. On Welwitschia, a new Genus of Gnetaceae. Trans. Linn. Soc. London 24: 1-48, pls. 1-14. 1863.

Ikano, S. Das Spermatozoid von Cycas revoluta. Bot. Mag. Tokyo 10: $367-368.1896$.

Vorläufige Mittheilung über die Spermatozoiden bei Cycas reroluta. Bot. Centralbl. 69: 1-3. $189 \%$.

Untersuchungen über die Entwickelung der Geschlechtsorgane und der Vorgang der Befruchtung bei Cycas revoluta. Jahrb. f. wiss. Bot. 32: 557-602. pls. 8-10. 1898.

JACCARD, P. Le Développement du Pollen de l'Ephedra Helvetica. Archives des sci. Phys. et Nat. III. 30: 280-282. 1893. See review in Beih. zum Bot. Centralbl. 4: 230. 1894.

Recherches embryologiques sur l'Ephedra Helvetica. Bull. Soc. Vaudoise des sci. Nat. 30: 46-84. pls. 3-10. 1894. See review in Bot. Centralbl. 61: 111-113. 1895.

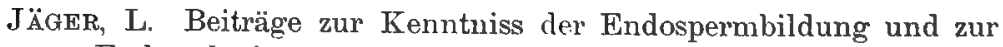
Embryologie von Taxus baccata. Flora 86: 241-2ss. pls. 1519. 1899.

Juranyi, L. Bau und Entwickelung des Pollens bei Ceratozamin longifolia. Miq. Jahrb. f. wiss. Bot. 8: $380-400$. pls. 31-34. 1872.

Karsten, H. Beiträge zu Entwickelungsgesch. der Gattung Gnetum. Bot. Zeit. 50: 205-215, 221-231, 237-246. pls. 5-6. 1892.

Untersuchungen über die Gattung Gnetum. Ann. Jard. Bot. Buitenzorg 11: 195-218. pls. 17-19. 1893. 
Karsten, H. Zur Entwickelungsgesch. der Gattung Gnetum. Cohn's Beitr. z. Biol. d. Pflzn. 6: 337-382. pls. 8-11. 1893.

LANG, W. H. Studies in the Development and Morphology of Cycadean Sporangia. I. The Microsporangia of Stangeria paradoxa. Ann. Bot. 11: 421-438. pl. 22. 1897.

Studies in the Development and Morphology of Cycadean Sporangia. II. The Ovule of Stangeria paradoxa. Ann. Bot. 14: 281-306. pls. 17-18. 1900.

Lotsy, J. P. Contributions to the Life-history of the Genus Gnetum.

Ann. Jard. Bot. Buitenzorg II. 1: 46-114. pls. 2-11. 1899.

Mettenius, G. H. Beiträge zur Anatomie der Cycadeen. AbhandI. d. königl. Sächs. Gesell. d. wiss. 7: 565-608. pls. 1-5. 1861.

Miquel, F. A. W. Monographia Cycadearum. 1-82, pl.8. 1841.

MotTier, D. M. On the Archegonium and Apical Growth of the Stem in Tsuga Canadensis and Pinus silvestris. Bot. Gaz. 17: 141-143. pl. 8. 1892.

Murrill, W. A. The Development of the Archegonium and Fertilization in the Hemlock Spruce (Tsuga Canadensis). Ann. Bot. 14: 583-607. pls. $31-992.1900$.

Otrsted, A. S. Bidrag til Naaletroeernes Morphologi. Videnskab. Meddelelser Nat. Foren. Copenhagen. 1864.

Parlatore, F. Studi Organografici sui Fiori e sui Frutti delle Conifere. Opuscula botanica. 1864.

Pax, F. Allgemeine Morphologie der Pflanzen mit besonderer Berücksichtigung der Blüthenmorphologie. 1890.

ReINke, J. Parasitische Anabaena in Wurzeln der Cycadeen. Gött. Nachr. 107. 1872.

SACHS, J. Lehrbuch. 1868.

Schleiden, M. J. Sur la Signification Morphologique du Placentaire. Ann. Sci. Nat. Bot. II. 12: 373-376. 1839.

SchreIder, A. Mutualistic Symbiosis of Algae and Bacteria with Cycas revoluta. Bot. Gaz. 19: 25-32. pl. 3. 1894.

Scoxt, D. H. The Anatomical Characters presented by the Peduncles of Cycadaceae. Ann. Bot. 11: 399-419. pls. 20-21. 1897.

Studies in Fossil Botany. London. 1900.

On the Occurrence of a Seedlike Fructification in certain Paleozoic Lycopods. Ann. Bot. 14: 713-717. 1900.

SEward, A. C., and Gowan, Miss J. The Maiden Hair Tree (Ginkgo biloba L.). Ann. Bot. 14 : 109-154. pls. 8-10. 1900.

SHaw, W. R. Contribution to the Life-history of Sequoia. Bot. Gaz. 21: 332-339. pl. 24. 1896.

Sorolowa, Mlle. C. Naissance de l'Endosperme dans le Sac embryonnaire de quelques Gymnospermes. Moscou. 1880.

Solms-Laubach, H. Die Sprossfolge der Stangeria und der übrigen Cycadeen. Bot. Zeit. 48: 177-187, 193-199, 209-215, 225-230. pl. 2. 1890 . 
Solms-Laubach, H. Ueber die Fructification von Bennettites Gibsonianus Carr. Bot. Zeit, 48: 789-798, 805-815, 821-833, 843-847. pls. 9-10. 1890.

Fossil Botany. Oxford. 1891.

Stenzel, G. Beobachtungen an durchwachsenen Fichtenzapfen. Ein Beitrag zur Morphologie der Nadelhölzer. Nov. Act. Nat. Cur. 38: 289-350. pls. 19-15. 1876.

Strasburger, E. Die Befruchtung bei den Coniferen. 1869.

Die Coniferen und die Gnetaceen. 1872.

Die Befruchtung und Zelltheilung. Jen. Zeitsch. 2: 435-536. pls. $27-35.1877$.

Befruchtung und Zelltheilung. 1878.

Die Angiospermen und die Gymnospermen. 1879.

Neue Untersuchungen, etc. 1884.

Histologische Beiträge 3: 151. 1891.

Ueber das Verhalten des Pollens und die Befruchtungsvorgänge bei den Gymnospermen. Hist. Beitr. 4: 1-158. pls. 1-3. 1892.

TreuB, M. Recherches sur les Cycadées. Ann. Jard. Bot. Buitenzorg 2: 32-53. pls. 1-7. 1881 (date of reprint, volume date being 1885).

Recherches sur les Cycadées. 3. Embryogenie du Cycas circinalis. Ann. Jard. Bot. Buitenzorg 4: 1-11. pls. 1-3. 1884.

Van Tieghem, Ph. Anatomie comparée de la Fleur femelle et du Fruit des Cycadées, des Conifères, et des Gnetacées. Ann. Sci. Nat. Bot. V. 10: 269-304. pls. 18-16. 1869.

Recherches sur la Symetrie de Structure des Plantes vasculaires. Ann. Sci. Nat. V. 13: 1-314. pls. 3-8. 1870.

VoN MoHL, Hugo. Ueber die Männlichen Blüthen der Coniferen. Verm. bot. Schriften 45-61. 1845. (Published as a dissertation, 1837.)

Ueber den Bau des Cycadeen-Stammes. Abhandl. d. königl. d. Acad. zu München 1: 1832. Republished and revised in Vermischte Schriften 195-211. 1845.

Morphologische Betrachtung der Blätter von Sciadopitys. Bot. Zeit. 29: 17-23. 1871.

WARMing, E. Recherches et Remarques sur les Cycadées. Oversigten over d. K. D. Vidensk, Selsk. Forh. $187 \%$.

Contributions à l'Histoire naturelle des Cycadées. Ibid. 1879.

WebBer, H. J. Peculiar Structures occurring in the Pollen Tube of Zamia. Bot. Gaz. 23: 453-459. pl. 40. 1897.

The Development of the Antherozoids of Zamia. Bot. Gaz. 24: 16-22. 1897.

Notes on the Fecundation of Zamia and the Pollen Tube Apparatus of Ginkgo. Bot. Gaz. 24: 225-235. pl. 10. 1897.

Wibland, G. R. A Study of some American Fossil Cycads. Part I. The Male Flower of Cycadeoidea. Am. Jour. Sci. IV. 7: 22:3226. pls. $2-4 . \quad 1899$. 
Wieland, G. R. A Study of some American Fossil Cycads. Part III. The Female Fructification of Cycadeoidea. Am. Jour. Sci. IV. 7: 383-391. pls. 8-10. 1899.

The Yale Collection of Fossil Cycads. Yale Sci. Month. 6: 1-11. pl. 1. 1900.

Worsdell, W. C. Anatomy of Stems of Macrozamia compared with that of other Genera of Cycadeae. Ann. Bot. 10: 601-620. pls. 27-28. 1896.

The Anatomical Structure of Bowenia spectabilis. Ann. Bot. 14: $159-160.1900$.

The Structure of the Female "Flower" in Coniferae. Ann. Bot. 14: 39-82. 1900.

The Vascular Structure of the Ovule of Cephalotaxus. Ann. Bot. 14: 317-318. 1900.

The Affinities of the Mesozoic Fossil, Bennettites Gibsonianus. Ann. Bot. 14: 717-721. 1900.

WoyciokI, Z. On Fertilization in Coniferae (in Russian). pp. 1-57. pls. 2. 1899. 



\section{A P P E N D I X}

A paper by Mr. W. A. Murrill,* on Tsuga Canadensis, has reached us too late to incorporate his results in the body of the text.

The time which elapses between pollination and fertilization is quite different from that we have given for Pinus. Two weeks after pollination the archegonium initials become evident, one week later the neck of the archegonium is formed, two weeks later the ventral canal cell is cut off, and five days later fertilization occurs. As contrasted with Pinus, this period of less than six weeks between pollination and fertilization is remarkably short.

The neck of the archegonium exhibits considerable variation, consisting of one to four cells. The ordinary number is two, and the wall between them is usually oblique, although it may vary in direction from transverse to longitudinal.

The author was not able to discover any passage of nuclei from the jacket cells to the central cell through wall pores.

The two male cells are unequal in size, the diameter of the functional one being twice that of the other. It would be interesting to know whether this results from an unequal division of the body cell, as in Taxus, or from unequal growth.

The nuclei of both male cell and egg pass into the resting stage before fusion, an observation directly at variance with the reported behavior of these nuclei in Pinus.

* The Development of the Archegonium and Fertilization in the Hemlock Spruce (Tsuga Canadensis). Ann. Bot. 14: 583-607. pls. 31-32. December, 1900. 
As in Pinus, the chromatin masses of the sex nuclei remain separate until segmentation into chromosomes takes place. These chromosomes do not fuse, but mingle indiscriminately near the center of the spindle. The evidence is thus accumulating that male and female chromosomes may remain distinct, and pass without fusion into succeedirg cell generations. 


\section{BOOKS BY FRANK M. CHAPMAN.}

\section{BIRD STUDIES WITH A CAMERA.}

With Introductory Chapters on the Outfit and Methods of the Bird Photographer. By Frank M. Chapman, Assistant Curator of Vertebrate Zoology in the American Museum of Natural History; Author of "Handbook of Birds of Eastern North America" and "Bird-Life." Illustrated with over 100 Photographs from Nature by the Author. 12 mo. Cloth, \$I.75.

Bird students and photographers will find that this book possesses for them a unique interest and value. It contains fascinating accounts of the habits of some of our common birds and descrip-. tions of the largest bird colonięs existing in eastern North America; while its author's phenomenal success in photographing birds in Nature not only lends to the illustrations the charm of realism, but makes the book a record of surprising achievements with the camera. The book is practical as well as descriptive, and in the opening chapters the questions of camera, lens, plates, blinds, decoys, and other pertinent matters are fully discussed, making the work an admirable guide for the camera hunter.

\section{$B I R D-L I F E$.}

$A$ Guide to the Study of our Common Birds. With 75 full-page Plates and numerous Text Drawings by Ernest Seton-Thompson. Library Edition, I 2mo, cloth, \$1.75; Teachers' Edirron, same as Library Edition, but containing an Appendix, with new matter designed for the use of teachers, and including lists of birds for each month of the year, 1 2mo, cloth, \$2.00. Edition with 75 Colored Lithographic Plates, 8vo, cloth, $\$ 5.00$.

TEACHers' MANUAL. To accompany Portfolios of Colored Plates of "BirdLife." Contains the same text as the Teachers" Edition of "Bird-Life," but is without the 75 uncolored plates. Sold only with the Portfolios, as follows :

Portrolto No. I.-Permanent Residents and Winter Visitants. 32 plates.

Portrolio No. II.-March and April Migrants. 24 plates.

Portrolio No. III.-May Migrants, Types of Birds' Eggs, and 9 half-tone plates showing Types of Birds' Nests. 34 plates.

Price of Portfolios, each, \$1.25; with the Manual, \$2.00. The three Portfolios, with the Manual, $\$ 4.00$.

\section{HANDBOOK OF BIRDS OF EASTERN NORTH AMERICA.}

With Keys to the Species, Descriptions of their Plumages, Nests, etc., and their Distribution and Migrations. With over 200 Illustrations. I $2 \mathrm{mo}$. Library Edition, \$3.00; Pocket Edition, flexible covers, $\$ 3.50$.

\section{APPLETON AND COMPANY, NEW YORK.}




\section{APPLETON \& CO.'S PUBLICATIONS.}

\section{The Ice Age in North America,}

AND ITS BEARINGS UPON THE ANTIQUITY OF MAN. By G. Freneryok Wright, D. D., LL. D. With 148 Maps and Illustrations. Third edition, containing Appendix on the "Probable Cause of Glaciation," by WARReN UPHAM, F. G. S. A., and Supplementary Notes. 8vo. 625 pages, and complete Index. Oloth, $\$ 5.00$.

"Prof. Wright's work is great enough to be called monumental. There is not a page that is not instructive and suggestive. It is sure to make a reputation abroad as well as at bome for its distinguished author, as one of the most active and intelligent of the living students of natural science and the special department of glacial action." - Philadelphia Bulletin.

\section{The Great Ice Age,}

AND ITS RELATION TO THE ANTIQUITY OF MAN. By JAMES Geikie, F. R. S. E., of H. M. Geological Survey of Scotland. With Maps and Illustrations. 12mo. Cloth, \$2.50.

A systematic account of the G]acial epoch in England and Scotland, with special reference to its changes of climate.

\section{The Cause of an Ice Age.}

By Siz Robert Ball, LL. D., F. R. S., Royal Astronomer of Ireland, author of "Starland." The first volume in the Modern Sorenoe Series, edited by Sir Jону Luввоск. 12mo. Oloth, \$1.00.

"An exceedingly bright and interesting discussion of some of the marvelous physical revolutions of which our earth has been the scene. Of the various ages traced and located by scientists, none is more interesting or can be more so than the Ice Age, and never have its phenomena been more clearly and graphically described, or its causes more definitely located, than in this thrillingly interesting volume."-Boston Traveller.

\section{Town Geology*}

By the Rev. Charles Kingslex, F. L.S., F. G.S., Canon of Chester. 12 mo. Cloth, $\$ 1.50$.

"I have tried rather to tench the method of geology than its facts; to furnish the student with a key to all geology; rough indeed and rudimentary, but sure and sound enough, I trust, to belp him to unlock most geological problems which may meet him in any quart." of the globe."-From the Preface.

\section{An American Geological Railway Guide.}

Giving the Geological Forunation along the Railroads, with Altitude above Tide-water, Notes on Interesting Places on the Routes, and a Description of each of the Formations. By James Macfardane, Ph. D., and more than Serenty-fire Geologists. Necond edition. 1890.426 pages. 8vo. Cloth, \$2.50.

"The idea is an original one, and its value is by no means confined to its originality. The book does not confne itsolf' to dry facts, hut in a series of foot-notes gives a great deal of information of general interest. The articles on the several States are by eminent scientific autborities. Mr. Mactarlnne has produced a very convenient and serviceable hand-book, available alike to the practical geolngist, to the student of that science, and to the intelligent Evening Tho would like to know the country through which he is passing." - Boston

New York: D. APPI.ETON \& CO., 72 Fifth Avenue. 



